\title{
Structural Issues in the Canadian Venture Capital Sector
}

\author{
by \\ Miwako Nitani \\ Master of Business Administration, Carleton University, 2001
}

A thesis submitted to the Faculty of Graduate and Postdoctoral Affairs in partial fulfillment of the requirements for the degree of

Doctor of Philosophy

in

Management

Carleton University

Ottawa, Ontario

(C2011, Miwako Nitani 
Library and Archives

Canada

Published Heritage

Branch

395 Wellington Street

Ottawa ON K1A ON4

Canada
Bibliothèque et

Archives Canada

Direction du

Patrimoine de l'édition

395 , rue Wellington

Ottawa ON K1A ON4

Canada
Your file Votre référence

ISBN: 978-0-494-79625-2

Our file Notre référence

ISBN: 978-0-494-79625-2
NOTICE:

The author has granted a nonexclusive license allowing Library and Archives Canada to reproduce, publish, archive, preserve, conserve, communicate to the public by telecommunication or on the Internet, loan, distribute and sell theses worldwide, for commercial or noncommercial purposes, in microform, paper, electronic and/or any other formats.

The author retains copyright ownership and moral rights in this thesis. Neither the thesis nor substantial extracts from it may be printed or otherwise reproduced without the author's permission.
AVIS:

L'auteur a accordé une licence non exclusive permettant à la Bibliothèque et Archives Canada de reproduire, publier, archiver, sauvegarder, conserver, transmettre au public par télécommunication ou par l'Internet, prêter, distribuer et vendre des thèses partout dans le monde, à des fins commerciales ou autres, sur support microforme, papier, électronique et/ou autres formats.

L'auteur conserve la propriété du droit d'auteur et des droits moraux qui protège cette thèse. $\mathrm{Ni}$ la thèse ni des extraits substantiels de celle-ci ne doivent être imprimés ou autrement reproduits sans son autorisation.
In compliance with the Canadian Privacy Act some supporting forms may have been removed from this thesis.

While these forms may be included in the document page count, their removal does not represent any loss of content from the thesis.
Conformément à la loi canadienne sur la protection de la vie privée, quelques formulaires secondaires ont été enlevés de cette thèse.

Bien que ces formulaires aient inclus dans la pagination, il n'y aura aucun contenu manquant. 


\begin{abstract}
This dissertation advances the thesis that the structure of the Canadian venture capital industry, comprised of a large number of relatively small funds and a small number of relatively large funds, is an important factor in increased reliance on foreign venture capital; on syndication and exit dynamics that differ from those in the United States; and on lower rates of return to Canadian investors.
\end{abstract}

Such a structure may limit the funding that any one venture capital fund can allocate to a given enterprise, possibly to the extent that a single fund may not have sufficient capital to take an investee firm to its optimal exit. As growth of the investee firm demands ever larger amounts of financing the investor's capital constraint may oblige the investee firm to seek additional sources of capital. This diverts management of the firm away from development of technology and management of growth. If not found, underinvestment problems ensue. Moreover, if the syndicate ultimately comprises a large number of investors, increased costs of syndication could negatively affect investors' activities to contribute non-financial capital to the investee.

Given the relative scarcity of large funds in Canada, ownership teams may be obliged to seek foreign sources of venture capital. Moreover, incumbent investors' weak position at the negotiation table facilitates the large entrant investors' ability to hold-up the incumbents and drive down the value of incumbents' investments. This can compromise the motivation and efforts of the founding team and create an ongoing enmity within the ownership team thereby reducing the likelihood of success. This may be exacerbated due 
to excess syndication further prompting dysfunctional and cumbersome investor syndicates. To avoid this, the incumbents and the entrepreneur may decide to sell the firm prematurely, leading to relatively more M\&A exits and fewer IPOs.

The empirical observations were generally consistent with the view that the predominance of small funds has led a high level of (otherwise unnecessary) syndication, increasing reliance on foreign capital, and fewer successful exit outcomes. This suggests the possible necessity of redesigning the entire sector, including the means of government intervention. 


\section{TABLE OF CONTENTS}

I. INTRODUCTION 1

1. Overview 1

2. Importance of the Topic 10

2-1. Importance to Policy Makers 10

2-2. Importance to the Academic Literature 14

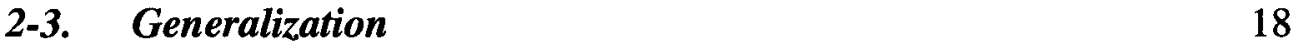

II. LITERATURE REVIEW 22

1. Venture Capital Investment - Overview and the 24 Canadian Context

1-1. Venture Capital Investment - Overview 24

1-1-1. Definitions 24

1-1-2. Investment Stages 26

1-1-3. Investment Process 29

1-1-4. Value-Added Activities 31

1-1-5. Information Asymmetry 34

1-1-6. Contracts 36

1-1-7. Securities Used 40

1-1-8. Staged Investment 43

1-1-9. Summary 45 
1-2. The Canadian Venture Capital Industry 46

1-2-1. The Size 46

1-2-2. Sector, Stage, and Regional Distributions 49

1-2-3. Types of Funds

1-2-4. Source of Funds $\quad 56$

1-2-5. Labour Sponsored Venture Capital Corporations $\quad 59$

1-2-6. Fund Managers' Skill $\quad 70$

1-2-7. Entrepreneurial Base 71

1-2-8. Rates of Return 72

1-3. Conclusion - Small Size Causing Capital Constraint Problems?

2. Syndication Practice in Venture Capital 78

$\begin{array}{ll}\text { 2-1. Definition } & 79\end{array}$

2-2. Theoretical Rationales for Syndication: Risk-Sharing 80 versus Resource-Based Motives

2-2-1. The Risk-Sharing Hypothesis 81

2-2-2. The Resource-Based View 82

2-3. Risk-Sharing versus Resource-Based Motives-Empirical 86 Evidence

2-3-1. Empirical Evidence Supporting the Risk-Sharing Hypothesis

2-3-2. Empirical Evidence Supporting the ResourceBased View

2-4. Challenges to Testing Motives for Syndication 97

2-5. Syndication Decision-Making as a Complex Process 102 
2-5-1. Simultaneous Presences of the Risk-Sharing and the Resource-based Motives

2-5-2. Trade-offs between Diversification and Dilution of Human Capital

2-5-3. Trade-offs between Diversification and Portfolio Focus

2-5-4. Costs of Syndication

2-6. Conclusion - Small Size Causing Capital Constraint Problems?

\section{Exit Activities in Venture Capital}

3-1. Types of Venture Capital Investment Exits

3-2. Factors Affecting Exit Routes, Exit Timing, and Investment Duration

3-2-1. Information Asymmetry

3-2-2. Contractual Provisions

3-2-3. Monitoring and Involvement

3-2-4. Reputation

3-2-5. Network Ties

3-2-6. The Exit Environment

3-2-7. Deal and Investee Firm Attributes

3-2-8. Attributes of Venture Capital Firm/Fund

3-3. The Duration of Venture Capital Investments

3-4. Conclusion - Small Size Causing Capital Constraint Problems? 
1. Introduction: On the Size of Venture Capital Funds

2. Capital Constraints?

3. The Bottleneck Hypothesis

4. Syndication Practice

5. Venture Capital Exit

5-1. Conceptual Rationale

5-2. Testable Hypotheses

6. The Bottleneck Chain

1. Data

1-1. Thomson Financial VCReporter

1-2. Venture Economics SDC Platform

1-3. MoneyTree Report

2. Descriptive Statistics

2-1. Investee Companies

2-2. Investment Deals

2-3. Venture Capital Funds/Firm 
1. Results on Syndication Practice

1-1. Hypothesis 1 207

1-1-1. Analysis of the Canadian Data 207

1-1-2. Comparisons with the United States 214

1-1-3. Summary of Results of Hypothesis 1 220

1-2. Hypothesis 2 and $3 \quad 223$

1-2-1. Syndication Ratio 224

1-2-2. Logistic Regression: First Rounds 232

1-2-3. Logistic Regression: Later Rounds 242

1-2-4. Summary of Results of Hypothesis $2 \& 3$

1-3. Hypothesis 4 254

1-3-1. Canadian Analysis 254

1-3-2. US-Canada Comparison 262

1-3-3. Summary of Results of Hypothesis $4 \quad 266$

1-4. Hypothesis 5a 268

1-4-1. Pairwise and Multinomial Logistic Regression 269 Models Regression Models

1-4-3. Summary of Results of Hypothesis 5 a

1-5. Hypothesis 5b 284

1-5-1. Pairwise and Multinomial Logistic Regression 285 Models 
Regression Models

1-5-3. Summary of Results of Hypothesis $5 a$

1-6. Summary of Results of Syndication Analyses 297

2. Results on Exit Practice 302

$\begin{array}{ll}\text { 2-1. Hypothesis } 6 & 302\end{array}$

2-2. Hypothesis 7 and $8 \quad 308$

2-3. Hypothesis 9 and $10 \quad 320$

2-4. Hypothesis $11 \quad 321$

2-5. Summary of Results of Exit Analyses 324

3. Robustness Check 326

3-1. Size Measures $\quad 326$

3-2. Other Robustness Checks 330

VI. CONCLUSION 334

1. Main Findings in relation to the Bottleneck Hypothesis 334

2. Implications of the Results $\quad 340$

2-1. Implications for the Academic Literature 340

2-2. Implications for Entrepreneurs 342

2-3. Implications for Policy Makers 343

2-3-1. Quebec Phenomenon 344

2-3-2. Toward a More Effective Venture Capital Sector 351 
3. Limitations of This Study and Areas for Future Research

3-1. Limitations of This Study

3-1-1. Comparison of Returns between Early and Later $\quad 358$ Stage Investors

3-1-2. Alternative Interpretations 359

3-1-3. Outcome Focus (as opposed to Process Focus) 363

3-2. Directions for Future Research 365

3-2-1. More on Bottleneck 366

3-2-2. Impacts of Bottleneck on Entire Entrepreneurial $\quad 370$ Activities

3-2-3. Towards an Active Canadian Venture Capital 372 Market 


\section{LIST OF TABLES}

Table I-1: Average fund size in Canada and the United States

Table II-1: Brander, Amit, and Antweiler's (2002) Size Statistics

Table II-2: Comparison of Exit Value, Amount of Capital Infusion, and Frequency of American Exit between Companies with Foreign Investors and Those without

Table II-3: Comparison of Exit Value between Canada and the United States

Table II-4: Average Size of an Investment by a Single Investor

Table IV-1: Industry and Location Breakdowns of Investee Firm

Table IV-2: Number of Investments and Average Amount Invested per Year

Table IV-3: Size, Type, and Geographic Distribution of Canadian VC funds

Table IV-4: Canadian Funds with Capital under Management Greater than or Equal to $\$ 165$ million CDN

Table IV-5: Data Available via VCReporter Data Tables

Table IV-6: Variables Available via VCReporter Keyword Search Facility

Table IV-7: Variables Available via VCReporter Database

Table V-1: Estimated Correlation Coefficient between Size and Measures of Capital Availability

Table V-2: Rotated (Varimax) Component Matrix of Capital Availability Measures

Table V-3: Poisson Regression on Number of Portfolio Companies

Table V-4: Average Syndication Ratios by Type of Funds in Canada and Germany

Table V-5: Logistic Regression: Syndication Ratio

Table V-6: Logistic Regression on the Odd Ratio of Syndication (First Rounds) 
Table V-7: Logistic Regression on Probability of New Investor Entry (Later Rounds)

Table V-8: Poisson Regression on Number of Syndicate Members (All Rounds)

Table V-9: US-Canada Comparison of Number of Investors per Deal

Table V-10: Poisson Regressions on Number of Investors

Table V-11: Pairwise Logistic Regression on Probability of Large (Small) Fund Entry (Later Rounds)

Table V-12: Multinomial Logistic Regression on Probability of Large Fund Entry, Small Fund Entry, and No Entry (Later Rounds)

Table V-13: Pairwise Logistic Regression on Probability of Foreign (Canadian) Fund Entry (Later Rounds)

Table V-14: Multinomial Logistic Regression on Probability of Foreign Fund Entry, Canadian Fund Entry, and No Entry (Later Rounds)

Table V-15: Summary of Results of Syndication Analyses

Table V-16: OLS Regression on Amount Invested by the Time of Exit

Table V-17: Proportional Hazard Model on Time to Successful Exit, M\&A,

Table VI-1: 29 Large Canadian Funds ranked by Capital Availability

Table A-1: List of Controlling Variables for Analyses on Syndication

Table A-2: $\quad$ List of Controlling Variables for Analyses on Exit

Table A-3: ANOVA and Post-hoc t-tests of Capital Availability

Table A-4: OLS Regressions on capital Availability Measures

Table A-5: Poisson Regression on Number of Portfolio Companies

Table A-6: Correlation between Size and Experience Measures

Table A-7: Contingency Table between Number of syndicate Members and Presence of Foreign Fund 
Table A-8: Contingency Table between Number of syndicate Members and Size of the Syndicate

Table A-9: Contingency Table between Size of the Syndicate and Presence of Foreign Fund

Table A-10: OLS Regression on Total Amount Invested by the Time of Exit 


\section{LIST OF FIGURES}

Figure I-1: Cumulative Distribution of Venture Capital Fund Size, United

States and Canada

Figure III-1: Effect of Fund Size on Management's and Private Partners'

Returns (reproduced from Murray \& Marriott, 1998)

Figure III-2: The Bottleneck Chain

Figure V-1: Average Number of Portfolio Companies by Size Categories; All Fund Types

Figure V-2: Average Number of Portfolio Companies by Size Categories;

Private Independent Funds

Figure V-3: Distribution of VC Funds by Size; All Fund Types

Figure V-4: Distribution of VC Funds by Size; Private Independent Funds

Figure V-5: Distribution of VC Funds by Syndication Ratio 


\section{LIST OF APPENDICIES}

Appendix I: Control Variables for Analyses on Syndication Patterns

Appendix II: Control Variables for Analyses on Exit

Appendix III: ANOVA, OLS, and Poisson Regression Analyses on Capital Availability

Appendix IV: Correlation Coefficient Estimates between Size and Experience

Appendix V: Contingency Tables between Size of Syndicate, Number of Investors, and Presence of Foreign Fund

Appendix VI: OLS Regression on Total Amount Invested with "Percentageof-Large Funds" Variable 


\section{INTRODUCTION ${ }^{1}$}

On December $9^{\text {th }}, 2004$, Chantry Networks, a leading provider of secure integrated mobility management solutions for WLAN, announced that it had agreed to be acquired by Siemens Communications, one of the largest players in the global telecommunications industry (WALTHAM, Mass., BUSINESS WIRE).

\section{Overview}

It is often questioned why Canadian enterprises seem so frequently to be acquired by foreign corporations, and whether this is good for the Canadian business environment and the economy as a whole. In particular, the significant presence of foreign investors in the Canadian venture capital markets is an issue of substantial debate given that more than half of the venture capital-backed Canadian firms that exited through merger and acquisition (M\&A) between 2002 and 2006 were acquired by foreign corporations (Duruflé, 2007, p.10). ${ }^{2}$ According to Canadian Newswire Services (2008): ${ }^{3}$

The recent sell-off of some of Canada's most iconic companies has sparked a fierce and often emotional debate about foreign ownership and what it means to the economy and the country.

\footnotetext{
${ }^{1}$ Following Hochberg, Ljungqvist, and Lu (2007), we distinguish venture capital funds from venture capital firms: whereas venture capital funds have a limited (usually ten-year) life, the venture capital firm that manages the fund has no predetermined lifespan. A venture capital firm may manage more than one fund. In this work, as is customary in this research literature, a general partner who manages the venture capital fund (or, sometimes the venture capital firm/fund itself) is referred to as a venture capitalist. Following Cumming and MacIntosh (2001b), we refer to an entrepreneurial firm as a small, private, and often high-technology business with high growth potential. The word "entrepreneur" refers to the entrepreneur(s), founder(s) or manager(s) of the entrepreneurial firm (or, sometimes the entrepreneurial firm itself).

${ }^{2}$ Brander, Egan, and Hellmann (2008) present a similar figure: 44 percent of the Canadian venture capital backed entrepreneurial firms that exited through acquisition between 1996 and 2004 were acquired by publicly-traded American corporations.

3 http://www.newswire.ca/en/releases/archive/January2008/24/c3962.html, TORONTO, Jan. 24 /CNW Telbec/, accessed April 5, 2009.
} 
The presence of foreign entities is significant not only in the M\&A market to which Canadian venture capitalists bring their portfolio companies, but also in the Canadian venture capital market itself. Foreign (mainly American) venture capital funds play a vital role in Canada in terms of financing late, typically larger, rounds; exiting companies and obtaining high values. ${ }^{4}$ This situation poses several questions, one of which is whether or not the Canadian sector is sufficiently large. ${ }^{5}$

It could be argued that the Canadian venture capital industry is simply too small: that there is an insufficient supply of venture capital in the country, a capital market gap. However, for a gap to persist there must be an imperfection in the marketplace yet no evidence of an imperfection has been advanced. Moreover, international comparisons of the supply of venture capital across countries suggest that until the mid 2000s, the supply of venture capital in Canada was greater than that of almost every other country in the world and was comparable with that in the United States, on a per-unit-GDP basis (Bygrave and Quill, 2007). ${ }^{6}$

\footnotetext{
${ }^{4}$ Investments by foreign venture capital funds in Canadian enterprises totaled approximately $\$ 850$ million CDN in 2007, accounting for 41 percent of all venture capital investments in Canada. Foreign funds were present in all of the ten largest venture capital deals in 2007 , collectively providing 76 percent of the total dollar amount invested in those ten companies (Thomson Financial, 2008). In 2006, foreign funds were present in 28 percent of all M\&A exits, representing 42 percent by value. Foreign funds participated in 40 percent of those cases where the acquirers were American corporations, taking 89 percent of value (Duruflé, 2007). In 2009, the share of the amount of venture capital invested by foreign funds was approximately 30 percent (Thomson Financial, 2010).

$s$ One issue that arises frequently in the media is whether or not this so-called "hollowing out" is good news for Canada or not. This dissertation does not address this topic and leaves it for others to debate.

${ }^{6}$ However, the flow of venture capital investment in Canada has since decreased to approximately 0.1 percent of GDP, less than one half of the level in the United States in 2009 (Thomson Reuters, 2010).
} 
This thesis advances an alternative explanation: that what appears to be a relative shortage of venture capital is a consequence of the underlying structure of the industry: that the Canadian venture capital industry is comprised of a large number of relatively small funds and a small number of relatively large funds, resulting in a "bottleneck." Figure I-1 illustrates the difference between Canada and the United States by showing the cumulative fund size distributions for the two countries. It shows, for example, that where almost 70 percent of Canadian venture capital funds hold less than $\$ 100$ million under management; yet, fewer than fifty percent of funds in the United States are so small. Also, Table I-1 compares the descriptive statistics for fund size data between Canada and the United States, both as of December 31, 2009. The difference in average fund size for venture capital is striking. The average American fund is almost three times larger than the average Canadian fund.

Figure I-1: Cumulative Distribution of Venture Capital Fund Size, United States and Canada (as of December 1009).

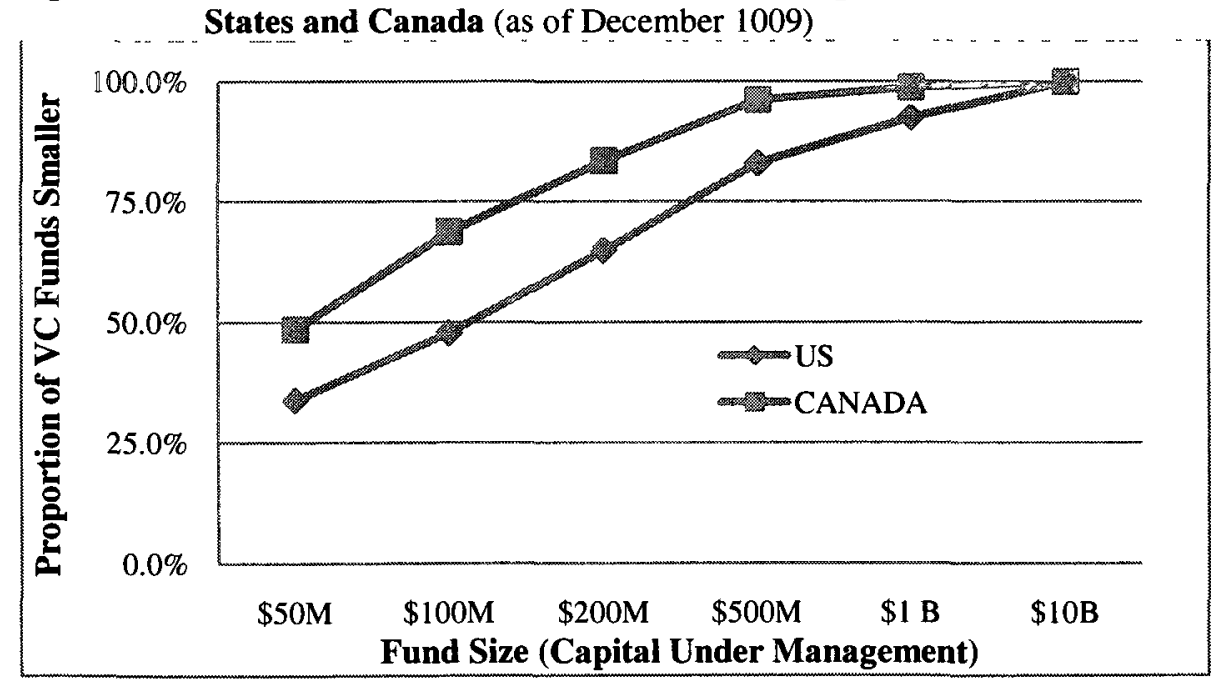


Table I-1: Average fund size in Canada and the United States

\begin{tabular}{l|lcc|ccc}
\hline & \multicolumn{3}{|c|}{ Canada } & \multicolumn{3}{c}{ US } \\
& $\begin{array}{l}\text { Mean }(\$ \text { in } \\
\text { millions })\end{array}$ & $\mathrm{N}$ & S.E. & $\begin{array}{c}\text { Mean }(\$ \text { in } \\
\text { millions })\end{array}$ & $\mathrm{N}$ & S.E. \\
\hline Venture Capital & 118.0 & 237 & 13.8 & 335.1 & 3357 & 13.5 \\
Buyout & 489.5 & 75 & 145.3 & 712.35 & 2127 & 38.1 \\
Mezzanine & 160.8 & 24 & 27.2 & 177.6 & 581 & 13.8 \\
\hline
\end{tabular}

This market structure may hold some advantages in facilitating growth of businesses in their early stages (small funds often specialize as early stage investors and provide considerable non-financial value-added). ${ }^{7}$ On the other hand, such a structure may limit the total funding that any one venture capital fund can allocate to a given enterprise - to the extent that a venture capital fund may not by itself have sufficient capital to take the investee firm to the optimal exit. This has further implications.

First, a capital constraint on a fund may oblige the investee firm and the venture capital investor(s) to seek additional sources of capital as growth of the investee firm requires ever larger rounds of financing. Founders of firms in which venture capitalists typically invest are best suited to enhancing technological development of their firms, and search for external capital diverts the management of the investee firm away from a focus on growth of the firm in this regard. ${ }^{8}$ Moreover, finding suitable syndication partners may be

\footnotetext{
${ }^{7}$ For example, between 2002 and 2005, 49 percent of the amount of venture capital invested in Canada was invested in early stage businesses (53 percent in terms of number of financings), compared with only 19 percent in the United States (33 percent in terms of number of financings, Duruflé, 2006). This tendency continues, as 49 percent of the total amount of venture capital invested in Canada was in early stage companies (Thomson Financial, 2010).

${ }^{8}$ Of course, one of the important tasks of the management is raising capital. However, entrepreneurs typically have engineer backgrounds and started their businesses based on their technological innovations.
} 
exacerbated if there is a relative scarcity of large funds in the local financial sector. At some point, the firm and its investor(s) may be obliged to seek venture capital investors or acquirers from outside Canada: hence the presence of American investors at later stages of firm development. ${ }^{9}$ To the extent the "bottleneck" hypothesis holds, it seems reasonable to expect that smaller funds would face relatively greater capital constraints and would resort to syndication earlier and more often than would larger funds.

Second, this situation can also introduce dysfunctional dynamics. Incumbent small funds and early investors (including informal investors and founders) are likely to be in a weak position against the later-stage large-fund entrant investors at the negotiation table over a deal. This stimulates large entrant investors' incentive to hold-up incumbents and drive down the value of incumbents' investments in order to "buy low." The community, being short of large funds, gives deeper pocket entrant investors monopoly power, making it easy for them to hold up the small incumbent investors. ${ }^{10}$ This can create an ongoing enmity among members of the investee firms' Board of Directors, founders and senior

They are, in many cases, better at product development rather than financial management of their businesses.

${ }_{9}$ Another reason to seek American venture capital may be the imperative of establishing an American presence in the product market.

${ }^{10}$ One way for small funds to avoid this type of situation may be to form agreements or coalitions with large funds before they need additional sources of financing. However, coalitions are not binding and the shortage of large funds limits the number of potential coalition partners. Moreover, there are other factors limiting the accessibility to large funds. Those include: (1) large funds are geographically disbursed, and geographic scope of a fund's investments is often limited by securities regulation, direct and indirect costs of due diligence and monitoring of distant investments, and statutory constraints under which a fund operates (this is particularly true for Labour-Sponsored Venture Capital Corporations (LSVCCs) (see II-1$2-5)$ ); (2) even if large funds exist in the nearby community of a small fund, they may have already invested in a competitor to the entrepreneurial firm in which the small fund invites them to invest (competing investments are usually prohibited), or the large fund may hold differing investment preferences (stage, sector). 
managers, thereby reducing the likelihood of success. To avoid this, the incumbents and the entrepreneur may decide to sell the firm prematurely, leading to relatively more and earlier - M\&A exits and fewer IPOs.

This dissertation tested this "bottleneck hypothesis". It theoretically considered and empirically explored the extent to which small fund sizes have limited the amount of capital a venture capital fund can allocate to a given enterprise and the extent to which Canadian funds' syndication and exit practices are affected by small fund sizes. Empirical results were in general consistent with the bottleneck hypothesis: the structure of the Canadian venture capital industry (that is, the predominance of small funds and the relative scarcity of large funds) may be an important factor with respect to: the increased reliance on foreign venture capital; Canadian syndication dynamics that differ from American practices; and, the lower successful exit-rates of Canadian venture capital investments. More specifically, findings include:

- The amount of capital management of a fund is significantly positively correlated with measures of the capital availability of the fund;

- A high level of syndication activity was observed in Canada;

- Additional investors were more likely to be added to a syndicate when the incumbent syndicate is comprised of small venture capitalists than when it has one or more large or foreign venture capitalists; 
- Incumbent syndicates comprised of small venture capitalists were significantly more likely to add a new investor that is larger than the incumbents, whereas syndicates comprised of one or more large incumbent(s) were significantly less likely to do so;

- The probability of a foreign fund entry was significantly higher when the incumbent syndicate was comprised of very small funds;

- In many cases, (further) syndication was positively associated with the growth of the investee. In particular, a new foreign or large fund entry to an existing syndicate was more likely as the investee firms grew and required larger amounts of capital.

The above observations are consistent with the predictions of the bottleneck hypothesis that small fund sizes limit the amount of capital a fund can allocate to each of its investees and that small fund sizes necessitate relatively greater levels of syndication and reliance on foreign sources of capital, especially when the investee company successfully grows and requires a greater amount of capital.

Moreover, the comparison of syndication activities between Canada and the United States revealed that:

- Large funds (non-private independent funds in particular) in Canada maintained a disproportionally large number of investee firms in their portfolios, relative to those in the United States; 
- The number of investors per financing round was significantly larger in Canada than in the Unites States. The impact of a dollar increase in investment size on the number of investors was greater for Canadian deals.

Those observations suggest that in Canada, a relatively small number of large funds are frequently sought after as syndicate partners by a relatively large number of small funds, resulting in a high level of syndication activity not only for small but also for large funds. They further suggest that the financial capital (as well as the ability of managers of large funds to add non-financial contributions to their investees) of large funds is necessarily spread thinly, so investors and entrepreneurs must amass capital from many funds, both large and small. These results are consistent with the predictions of the bottleneck hypothesis: a higher level of syndication activities results when investors are small, when investee firms require large capital infusions as they grow, and when a venture capital community is comprised of few large funds and many small funds.

Finally, the analyses of exit practices of the Canadian venture capital funds revealed that:

- The total amount of venture capital infused into an exited entrepreneurial firm (by the time of its exit) significantly increases when it is backed by a large fund(s) or by a larger number of investors; 
- Entrepreneurial firms backed by a syndicate with one or more large fund or with a large number of investors were significantly more likely to attain an M\&A exit over a given time.

These are also consistent with the Bottleneck hypothesis, which predicts: (1) a smaller amount of venture capital infusion to an entrepreneurial firm backed by small funds; and (2) a higher likelihood of a successful exit when investors are large and thus where a large amount of capital infusion is possible.

In general, the empirical observations support the view that the Canadian venture capital sector is bottlenecked: the predominance of small funds and the relative scarcity of large funds in the Canadian venture capital industry lead a high level of (otherwise unnecessary) syndication activities, an increasing reliance on foreign venture capital, and lower rates of successful exit outcomes. This suggests a possible need to redesign the entire sector, including re-consideration of means of government intervention. If Canadian investors (informal and early stage venture capitalists), who discovered and financed the Canadian companies at early stages of development, are obliged to rely on foreign funds (who are in a position to exploit their weak positions) it would harm the entire Canadian entrepreneurial sector and compromise the contributions to economic welfare from some of Canada's most dynamic firms. 


\section{Importance of the Topic}

This work is important from several perspectives. From the perspective of the practitioner, a bottlenecked venture capital sector can compromise entrepreneurs' objectives of creating and building a high growth business. A bottlenecked sector can lead to complex syndicates (some syndicates in Canada comprise more than 10 venture capital partners in addition to the founders and early-stage angel investors), which are costly to manage and in which decision-making is cumbersome. Excessive management time is consumed seeking the next round of investments and managing the complex webs of the investor syndicate. As a result, growth is compromised along with investors' and founders' hoped-for rates of return. Low rates of return compound the problem by discouraging investment in the sector and thereby continues the cycle.

\section{2-1. Importance to Policy Makers}

It is a widely held view that new enterprises are vital to economic growth and job creation; accordingly, factors that encourage the creation and growth of new enterprises remain of central interest to policy-makers. However, lack of access to financial capital is a constraint on the job-creating growth of new firms (e.g., Carpenter and Petersen, 2002). One purpose of venture capital is to provide high potential growth firms with the required funds and expertise to make these businesses successful (Sahlman, 1990). It is therefore an important mechanism for bringing innovations to market at a rapid pace, creating 
economic growth, improving productivity and establishing opportunities for further technological innovation. ${ }^{11}$

In Canada, the importance attached to the health of the institutional venture capital market has grown in concert with appreciation of the need to replace declining, traditional sources of economic output and jobs with new sources, especially as regards to knowledge-based productivity. To the extent that the growth of new enterprises and venture capital investments in those firms contribute to economic welfare and job creation, it is important for policy makers to ensure that the Canadian venture capital market is not structured in such a form that it discourages entrepreneurial activity.

There could be a serious problem for the Canadian venture capital market if its structure leaves venture capital funds unable to allocate sufficient amounts of capital to bring their portfolio companies to optimal exits. ${ }^{12}$ An industry with a scarcity of large funds may create a vicious cycle: it may put small funds, which are the majority in the industry, in a disadvantaged position (where it is difficult to take portfolio companies to the optimal exit), and the consequent low returns to those funds lead to decreased commitments to

\footnotetext{
${ }^{11}$ For example, Jeng and Wells (2000) quote the 1997 National Venture Capital Association annual study, which reveals that between 1991 and 1995, venture capital backed companies increased their staffs, on average, 34 percent per year, while over the same period, Fortune 500 companies decreased staffing levels four percent per year. Kortum and Lerner (2000) estimate that the impact of a dollar investment of venture capital on patenting is 3.1 times the size of the impact of a dollar investment in corporate $R \& D$, and that venture capital accounts for eight percent of industrial innovations (in terms of the number of patents) during the period between 1983 and 1992.

${ }^{12}$ Note that this dissertation's argument is not whether the aggregate amount of venture capital is sufficient in Canada. It hypothesizes that the structure of the Canadian venture capital may limit the amount of capital that each fund can allocate to each of its portfolio companies, and considers the consequences if this is the case. Also, this dissertation does not contend that "small is bad" - in any industry both large and small funds are necessary. The argument is on an issue of balance: the short supply of large funds in Canada.
} 
venture capital, which perpetuates smaller fund sizes. ${ }^{13}$ Surprisingly, however, few researchers have considered this structural problem. ${ }^{14}$ This dissertation addresses this gap.

In particular, this study investigates whether early-stage Canadian investors are disadvantaged. Early-stage capital is often seen as being crucial to the success of laterstage investments. Early-stage funds provide new firms with critical financing; therefore many policy initiatives around the world are aimed at increasing the availability of capital of this type (OECD, 1996). Gompers and Lerner (1999b) argue that entrepreneurial firms in their very early stages are the most prone to capital rationing and liquidity constraints because uncertainty and asymmetric information are the greatest. The presence of early stage investors, who discover, finance, and grow viable companies at the very early stage of development while providing considerable non-financial value-added services, is therefore one of the important contributions of a venture capital industry. If the structure of the Canadian venture capital industry puts the country's early stage investors, including venture capitalists, business angels, and founders, in a vulnerable position such that they bear the highest level of risk but receive inadequate compensation for that risk,

\footnotetext{
${ }^{13}$ Low returns, as well as the presence of LSVCCs (see II-1-2-5), lead institutional investors (e.g., insurance companies and pension funds) to shy away from investments in this asset class, causing the institutional funding available to venture capital in Canada to be spread too thinly across provinces/regulatory regimes. This limits funds from getting big. Possible factors causing low rates of return in Canadian venture capital investments include, besides the small fund sizes and the scarcity of large funds, the presence of LSVCCs, relatively less skilled fund managers, a relatively weak entrepreneurial base (see (also see II-1-2 and II-1-3 (1-2-4 1-2-8 in particular), as well as section six of Chapter III).

${ }^{14}$ Several studies (e.g., Murray, 1999, 2007; Duruflé, 2006) are aware of this potential problem, but they lack a thorough statistical analysis and thus are suggestive rather than conclusive.
} 
this would certainly discourage entrepreneurial activity. This dissertation, therefore, considers this possibility.

Venture capital investment is rare: the vast majority of small businesses will seek bank financing at some point in their development but only a small minority of young companies will also seek external equity finance in order to accelerate development. However, this minority of high potential young enterprises has a disproportionately large effect on prosperity, including employment creation and innovation. Accordingly, these firms have been, and continue to be, of considerable interest to policy makers. Support at the formative stages of these is especially important because new firms, while holding potential, are particularly vulnerable. Accordingly, the motive for governments to intervene using public funds to finance growth-intensive (and risky) young enterprises is overwhelming. Economic theory specifies that such interventions should rest on evidence that the financial markets are imperfect. Yet virtually every venture capital sector in the world, including that in the United States, had been founded with government involvement.

In Canada, governments have implemented two interventions at a cost to taxpayers that is of the order of \$15-20 billion CDN. One of these interventions is indirect support through the establishment of tax-incented Labour-Sponsored Venture Capital Corporations (LSVCCs) usually mandated to invest in early stage firms (see II-1-2-5). Governments have encouraged investment in LSVCCs by providing individuals with tax credits and tax 
deferrals on their investments in such funds. ${ }^{15}$ Collectively, these firms currently hold more than $\$ 10$ billion in capital under management. The second intervention is the Business Development Bank of Canada (BDC), along with the Export Development Bank of Canada (EDC), which invests taxpayer funds directly in young high-potential businesses as well as indirectly in other venture capital funds.

At the time these interventions were implemented, the rationale was that the market failure in the Canadian context was perceived as a lack of venture capital availability at the early stages of enterprise development. This is why LSVCCs, for example, were often specifically tasked with investing at early stages. The bottleneck hypothesis, on the other hand, suggests that there is an imperfection at the later stage of enterprise development: that successfully-growing entrepreneurial firms are unable to access late-stage venture capital because funds are too small. This exposes the most successful firms to foreign investors.

\section{2-2. Importance to the Academic Literature}

Venture capital activity has received considerable attention in the literature and has been explored from a variety of points of view. The venture capital industry is also an

\footnotetext{
${ }^{15}$ Individuals, depending on their marginal tax rate, can get tax credits for up to 30 percent of their investment in tax deferrals through investments that are included within Registered Retirement Savings Plans.
} 
important laboratory for scholars interested in settings where a variety of market frictions such as informational asymmetry, moral hazard, etc., are most amplified.

To the author's knowledge, this is the first study that exclusively investigates the size effect of venture capital funds. Several studies (e.g., Murray, 1999, 2007; Murray and Marriott, 1998; Dimov and Murray, 2006) suggest that small funds are financially constrained and disadvantaged due to scale and scope economies, but those studies do not carry out a thorough statistical investigation to obtain empirical support for their arguments. On the other hand, studies that observe a positive and significant association between size and performance (e.g., Laine and Torstila, 2003; Kaplan and Schoar, 2005; Hochberg, Ljungqvist, and Lu, 2007) generally interpret this association either as a manifestation that successful past performance enables venture capitalists to raise large funds (Kaplan and Schoar, 2005), or as a reflection that a larger universe of investments to choose from enables larger funds to fund more attractive opportunities (Laine and Torstila, 2003). However, the alternative explanation for size-performance relationship, i.e., it is because small funds are disadvantaged and financially constrained, has not been ruled out as those studies do not control for this possibility. In short, the mechanism through which fund size affects performance has not been fully investigated.

In this sense, this dissertation is the first study that investigates whether small funds are financially constrained, and if so, how this constraint might affect their syndication and exit practices. It is surprising that, while liquidity constraints, credit rationing, and financing gaps are so frequently discussed in the economic, finance, and entrepreneurship 
literatures, little research on these topics have been done in the venture capital setting. This study seeks to address this gap in the literature.

This is also the first study (to the author's knowledge) that addresses the hold-up problem by later stage investors versus early stage investors. A hold-up problem arises from a situation in which one party forces the other to accept an unfavourable outcome by threatening to take an action that prevents the other from further progress in the project. For example, in the venture capital setting, an entrepreneur can hold-up venture capital investors (pressure them into accepting an unfavourable condition) by threatening to leave the company. ${ }^{16}$ This type of a hold-up problem between entrepreneur and venture capitalists has been theoretically considered by Neher (1999) and Fluck, Garrison, and Myers (2005), and empirically examined by Kaplan and Stromberg $(2003,2004)$. The hold-up problem between entrant and incumbent investors arises from a situation in which the former compels the latter to accept undervaluation of the latter's investment by threatening not to join the syndicate. In the case where the entrant is virtually the only source of additional capital, this essentially means the end of the investee firm's growth. This type of hold-up problem has not been investigated either theoretically or empirically; this study addresses this gap. ${ }^{17}$

\footnotetext{
${ }^{16}$ To minimize this possibility, venture capitalists often include vesting and non-complete clauses in investment contracts, which make it difficult for the entrepreneur to leave the company (Kaplan and Stromberg, 2003; see II-1-1-6).

${ }^{17}$ Wright and Lockett (2003) and Cumming (2006) point out agency problems among venture capitalists in a syndicate, but they do not address the hold-up issue by entrants against incumbent investors.
} 
Admati and Pfleiderer (1994) argue that, in the absence of financial constraints, entrant venture capitalists are informationally disadvantaged, which may boost the incumbent venture capitalists' interest in driving up the firm's valuation when entrants are added. Lerner (1994a) finds evidence supporting Admati and Pfleiderer's argument in the American context, where capital constraints are unlikely. This paper argues that, in the presence of capital constraints, financially-limited incumbents are disadvantaged at the negotiation table, which may boost the entrants' interest in driving down the firm's valuation when entrants are added, resulting in higher returns for the entrants at the cost of the incumbents' returns. To the author's knowledge, this is the first study to consider the possibility of the hold-up problem by the entrant against incumbent investors, and empirically investigate it.

Also from the academic point of view, a debate over the optimal size of venture capital funds has been going on for more than a decade, without resolution. Such data as does exist do show that large venture capital funds do outperform smaller funds. ${ }^{18}$ However, interpretation of these findings is still not clear. One explanation is that large funds have managers who are relatively more capable of picking from a larger array of potential investee firms. Another related argument is that large funds are more widely approached for investment. A third alternative explanation is that large funds become large because the success of their managers inspires additional investment by financial institutions in

\footnotetext{
${ }^{18}$ This result is based exclusively on the United States experience, where - on an international scale - large funds are plentiful (and many funds that are viewed as relatively "small" in the United States are still relatively large in other countries including Canada, see Table I-1).
} 
high-performing funds: that success results in larger size. The school of thought pursued in this thesis is that small funds perform poorly because small fund sizes are uneconomic and result in the various problematic effects mentioned previously. Canada, with its plethora of small funds, provides an ideal laboratory to explore these debates and to add to our understanding of the syndication process.

This study therefore contributes to the literature in two respects: first, this is the first study that seeks to investigate the impacts of small fund sizes and capital constraints (as a potential consequent of small fund sizes) in the venture capital setting; and second, this is the first study that considers and empirically tests the hold-up problem by large, later stage investors vis-à-vis smaller, early stage investors.

\section{2-3. Generalization}

It appears that the situation in Canada is not unique outside the United States.

- Bygrave and Quill (2007) report that, in 2005, 71 percent of all the venture capital invested among the G7 nations was in the United States, and that while the average amount of venture capital invested per company in the United States was \$8.6 million US, the average among the other G7 countries was \$1.8 million US per company. ${ }^{19}$ They question how venture capital-backed companies outside the

\footnotetext{
${ }^{19}$ In Canada, the average deal size was $\$ 3$ million CDN in 2005 .
} 
United States can compete with similar companies in the United States when, on average, they have much less capital available.

- Hopp and Rieder (2006) observe that in Germany syndication combines the financial resources of the foreign venture capitalists with the skills and expertise of German venture capitalists, suggestive of German venture capitalists' reliance on foreign investors.

- Murray (1999) expresses concerns about British venture capitalists' dependence on, and disadvantage against, foreign investors.

- The fact that many governments (including the US government) have mounted programs that seek to promote venture capital financing also suggests perceived limitations of this type of capital, or perceived financing gaps in some segments in the industry (see, for example, Gilson, 2003; Lerner, 1999, 2002; Leleux and Surlemont, 2003; Cumming, 2007a).

These observations suggest that the issues presented in this dissertation are not just important in Canada and the results may have wider applicability. It is arguable that even though the Canadian setting may appear as an anomaly compared to that of the United States; it may not be so distinct with respect to Europe and other countries.

Moreover, the insights drawn from the investigation on the potential hold-up problem by large (more capital available) later stage investors against small (less capital available) 
early stage investors may also be applicable to the American setting. Bygrave (1987) contends that the largest venture capital firms in the Unites States have considerable influence, arguing that the extensive networks among the leading venture capital firms facilitate the establishment of a "market rate" for the companies they invest. ${ }^{20}$ Hibbard (2004), in his report on Silicon Valley venture capital activity, argues that large venture capital firms often use smaller ones as pipelines to deliver them promising new companies in which to invest. These studies suggest the possibility that the effects of size on negotiation power may be universal regardless of the structure of the industry. ${ }^{21}$

To address these issues, this dissertation is organized in the following manner. Chapter II reviews the existing studies on the characteristics of venture capital investments as well as the Canadian venture capital industry (section one), its syndication practices (section two), and the nature of exits (section three). The end of section one considers the characteristics of the Canadian venture capital industry that might have causal relationships with each other. The ends of sections two and three review previous studies' empirical observations that might be indications that small fund sizes cause capital constraints, and that financial limitations on funds might affect venture capitalists' investment practices, even if the studies do not explicitly acknowledge them. Chapter III

\footnotetext{
${ }^{20}$ Bygrave (1987) finds that as of the end of 1982, the top 61 among 464 venture capital firms in his sample were managing $\$ 4,330$ million US, which accounted for 57 percent of the pool of venture capital, and the other 400 or so were managing $\$ 3,270$ million US; 38 of the top 61 were located in California, New York, and Massachusetts, and three out of four venture capital-backed companies in his sample had at least one of the top 61 firms as an investor. Bygrave argues that these top 61 venture capital firms had an extensive network among themselves and with other venture capital firms.

${ }^{21}$ However, it is premature to conclude, based on Bygrave (1987) and Hibbard (2004), that small funds in the United States are also disadvantaged.
} 
presents the conceptual rationales behind the research questions, considers their implications, and develops the testable hypotheses. Chapter IV outlines the data. Chapter $\mathrm{V}$ describes the analytical techniques employed to test the various hypotheses advanced in Chapter III and presents the associated empirical findings. Chapter IV concludes this thesis. It includes a summary of the empirical findings, implications for the findings, and discussions on limitations of this study and possible directions for future research. 


\section{LITERATURE REVIEW}

This dissertation seeks to examine the effect of fund size on the syndication and exit practices of venture capital firms. This chapter therefore presents a review of the salient literature regarding these topics. To provide a structure to this literature, this chapter is organized as follows.

Section one provides an overview of the venture capital investment process with particular attention to the Canadian setting. It comprises three subsections:

- First, it presents key definitions and characteristics of venture capital investment in general, including investment stages, the investment process, and value-added activities of venture capitalists. The section then explores research about the nature and role of information asymmetry and venture capitalists' responses to it: contracting, usage of securities, and staging of investments.

- Second, this section presents a description of the Canadian venture capital market. This begins with a summary of the size and scope of the Canadian market. This is followed by a discussion of how venture capital investment is distributed in Canada with respect to sector, stage and region. Next, the work describes types of venture capital funds and sources of capitalization with particular attention to Labour Sponsored Venture Capital Corporations, a unique feature of the Canadian setting. In turn, this leads to a consideration of the level of skills of Canadian fund managers, the 
entrepreneurial basis for the market and the section concludes with a discussion of rates of return.

- Third, the section considers the characteristics of the Canadian venture capital sector that are possibly related each other.

Next, section two considers the process of venture capital syndication. It compares the two main theoretical paradigms (the risk-sharing hypothesis and the resource-based view) and reviews the empirical literature. The section includes a discussion of difficulties with respect to empirical research associated with the venture capital syndication practice. This leads to a consideration of the view that syndication decision-making is a complex process where multiple factors interact with each other, and that no single factor predominates. The section concludes with a review of how small fund sizes affect syndication through limiting a fund's availability of financial resources.

The third, and final, section of this chapter examines the research pertaining to the exit process. The various exit routes are described and research about factors that affect exit routes is presented along with related work on the duration of venture capital investments. This leads to a discussion, based on the literature reviewed, about how exit routes and timing might be related to size of fund. 


\section{Venture Capital Investment - Overview and the Canadian Context}

This section reviews characteristics of venture capital investment in general (subsection 1-1) and of the venture capital industry in Canada (1-2), focussing on the investment-side aspects of venture capital activities (as opposed to the fundraising side). The last subsection (1-3) the characteristics that are possibly subsequent to, or factors of, small fund sizes.

\section{1-1. Venture Capital Investment - Overview}

\section{1-1-1. Definitions}

The term 'venture capital' lacks a precise definition. According to Brander, Amit and Antweiler (2002), definitions of venture capital usually focus on four characteristics:

1. Financing for privately held companies: venture capital is generally described as capital invested by specialized funds in high-risk, high-growth-potential, and often technology firms that need capital to finance product development or growth (Black and Gilson, 1998; Aghion, Bolton, and Tirole, 2004).

2. Providing capital generally in the form of equity or long-term convertible debt. Convertible preferred equity is the form of financing most commonly used by American venture capitalists; however, Cumming (2002) notes that a variety of securities are used in other countries (see II-1-1-7). 
3. Serving as an intermediary between investors and entrepreneurs. This aspect of venture capital distinguishes venture capitalists from "angels," who invest their own money in fledgling companies. Venture capitalists obtain money from arm's length investors such as pension funds, other institutional investors and individuals (see II-1-2-4).

4. Management by a group of investors (venture capital fund managers) who specialize in financing of young, growing entrepreneurial firms. It is well documented that venture capitalists are actively involved in the development of investee firms, using their expertise to "add value" to the investments by providing investee firms with managerial advice and intensive monitoring, (Sahlman, 1990; Hellmann and Puri, 2002; among many others). The active role venture capitalists play in portfolio companies and the form of financing distinguishes venture capital from banking institutions (see II-1-1-4).

In general, venture capital funds are organized as limited partnerships with predefined lifetimes, usually ten years with an option to extend the fund for up to three years. Venture capitalists must liquidate investments and distribute proceeds to investors within the fund lifetime. Funds typically invest all their capital in the first five years and harvest investments during the last five. Venture capital firms must periodically raise follow-on partnerships in new funds to remain active in venture capital financing. Hence, venture capital firms may have two or three overlapping funds, each starting three to six years after a previous fund. Limited partners receive periodic updates about the status of 
projects and new investment activity of the fund, but their role in the day-to-day operations of the fund is restricted by law to retain their limited liability (Gompers, $1996)^{22}$

\section{1-1-2. Investment Stages}

Venture capital investments are often categorized into two groups, early and later stages, according to the investee firm's level of development. Sometimes each stage is further sub-categorized based on the investee's development or the purpose of financing. The Canadian Venture Capital Association (CVCA) defines three distinctive sub-stages within the early, and four sub-stages within later, stages. The definitions of these stages are as follows: ${ }^{23}$

Early stages of development:

- 'Seed': A business in this stage has not yet established commercial operations and needs financing for research and product development. Seed financing refers to

\footnotetext{
${ }^{22}$ This implies that evaluating a venture capitalist's ability is not straightforward; investors search for signals of ability when evaluating venture capitalists (Gompers, 1996). Venture capitalists typically receive: (1) a fixed fee compensation based on the size of the fund (two to three percent of assets under management per annum); and, (2) a percentage (typically 20 percent) of the fund's profits from investing: these give venture capitalists incentives to expand the firm's capital under management (Gompers, 1996). However, in other types of funds the compensation may not be as incentive-based as in independent funds (Gompers and Lerner, 1999b). See also Gompers and Lerner (1999c).

${ }^{23} \mathrm{http}: / /$ www.cvca.ca/resources/glossary.aspx, accessed April 2, 2009. These are definitions specific to CVCA. Other organizations have similar, but not identical definitions. Therefore, there remains considerable subjectivity with respect to these terms. See www.canadavc.com for Canada, www.vfinance.com, www.ventureeconomics.com, and www.vl.com for the United States, and www.evca.com for Europe.
} 
capital provided to facilitate commercialization of new product concepts, often from laboratories, research centres or entrepreneurs.

- Start-up: A business in this stage is in the earliest phase of established operations and needs capital for product development, initial marketing, the first-time establishment of a legal company structure around a marketable product concept, and other goals.

- Other early stage: A firm in this stage has begun initial marketing and related development and needs financing to achieve full commercial production and sales.

Later stages of development:

- Expansion: A business in this stage is an established or near-established company that needs capital to expand its productive capacity, marketing and sales.

- Acquisition/Buyout: A business in this stage is an established or near-established firm that needs financing to acquire all or a portion of a business entity.

- Turnaround: Restructuring/turnaround financing refers to capital provided to an established firm, usually in a traditional sector, that is undergoing financial distress or a major re-organization, but is perceived as having long-term commercial viability. 
- "Other stage": Financing classified in "other stage" (by the CVCA) includes secondary purchase (the sale of private or restricted holdings in a portfolio company by one investor to another), or the sale of portfolio assets among investors, and working capital financing. ${ }^{24}$

According to Brander, Amit, and Antweiler (2002), "Acquisition/Buyout" and "Turnaround" may also be categorized in "special purpose investments," which are usually one-time investments and might be made after the expansion phase. ${ }^{25}$ In North America, the term "venture capital" typically refers to capital provided to firms at the seed, start-up (or other early stage), or expansion stage of development (they are often referred to as "classic venture capital"). In European and Asian countries, however, it often refers to all private equity, including buyout and mezzanine financing, which

\footnotetext{
${ }^{24}$ In addition, there may be "bridge financing" that refers to capital provided on a short-term basis to a firm prior to its going public or its next major private equity transaction.

${ }^{25}$ The CVCA considers "Acquisition/Buyout" and "Turnaround" financing as a part of venture capital activities. These types of financing, however, appear to overlap with buyout and mezzanine funds' activities. According to the CVCA, buyout capital is a form of private equity, characterized mainly by risk investment in established private or publicly listed firms that are undergoing a fundamental change in operations or strategy. Mezzanine capital is a form of private equity, characterized chiefly by use of subordinated debt or preferred stock with an equity kicker, to invest largely in the same realm of companies and deals as buyout funds. Buyout and Mezzanine funds operate in a "middle market" where well established and mostly private companies in traditional sectors demand financing. A range of activity of interest to buyout and mezzanine funds includes:

- Divestiture financing: Capital provided to a firm for the sale of its interest in a product, division or subsidiary to another business entity.

- Management buyout financing: Capital provided for the takeover of all or part of a business entity by a team of managers.

- Re-capitalization financing: Capital provided for a significant overhaul of a firm's financial structure.

- Succession Plan: The basis for transfer of business ownership from one generation of managers to the next.

- Other buyout activity, merger/acquisition, and restructuring/turnaround.
} 
represent the vast majority of the private equity pool in those countries (Gompers and Lerner, 1999b). ${ }^{26}$

\section{1-1-3. Investment Process}

The nature of venture capital investing may be summarized as follows:

1. Deal selection: Venture capitalists receive a few hundred to a few thousand business plans per year. Most are rejected on sight so that detailed due diligence is carried out on about 20 percent of those plans (Cumming, Schmidt, and Waltz, 2006), and investment is made in approximately a dozen or so new companies (Sahlman, 1990).

2. Value-adding and monitoring: Once an investment is made the venture capitalist is actively involved in the entrepreneurial firm - closely monitoring and adding value to it. Venture capitalists' value-added activities include: playing an active role on the board of directors, mentoring and being a confidant to the CEO,

\footnotetext{
${ }^{26}$ In the United States and Canada, management buy-out/buy-in (MBO/MBI) investments are not considered venture capital but rather private equity investments. In contrast, in Europe the distinction between venture capital and buyout funds is not as clear (Black and Gilson, 1998, Schwienbacher, 2005). For example, Lockett and Wright (2001) and Schwienbacher (2005) include MBO/MBI transactions in their analysis of "venture capital" syndication in the United Kingdom. For definitions, see www.asiaventure.com for the Asia-Pacific region, www.evca.com for Europe, www.cvca.com and www.canadavc.com for Canada, www.vfinance.com, www.ventureeconomics.com, and www.vl.com for the United States.
} 
locating and recruiting management and technical personnel, playing networking roles, helping with structuring an IPO or an M\&A (see II-1-1-4).

3. Exit: The venture capitalist exits from the investment in the entrepreneurial firm.

"Classical"" venture capitalists typically invest in young, growing companies, most of which lack positive earnings and cash flows that would enable them to pay interest or dividends. They hold their gains until those companies become mature and profitable, at which point venture capitalists exit and harvest returns (in the form of capital gains) on their investments. This further means that venture capital investments are long-term, illiquid investments (Cochrane, 2001). ${ }^{27}$ Cumming and MacIntosh (2001b) report that venture capital investments in Canada typically have durations of from three to seven years, with an average of five years.

Three major characteristics of venture capital investments, often discussed in the literature, are: (1) while holding their investments, venture capitalists provide portfolio companies with not only money but also expertise necessary for those firms to be successful; (2) because investee firms are young, private companies with high growth potential, venture capitalists face more informational disadvantage and operate in a highrisk, high-uncertainty environment; and, (3) venture capitalists develop various mechanisms to deal with the asymmetric information and high uncertainty associated with their investments. Those characteristics imply that in the entire venture capital

${ }^{27}$ Other factors that make their investments illiquid include information asymmetry associated with privately held companies and restrictions imposed by regulatory authorities on transfers of unregistered securities (Sahlman, 1990). 
investment process described above (deal selection, investment, and exit), a special skill set is called for, one which is not easily replicated by other types of investors (Cumming and MacIntosh, 2002). The remainder of this subsection will examine in more detail venture capitalists' value-added activities (1-1-4), the informational asymmetry they face (1-1-5), and how they tackle asymmetric information problems and the high-uncertainty associated with their investments (1-1-6 to $1-1-8)$.

\section{1-1-4. Value-Added Activities}

Venture capitalists provide more than just money to their portfolio companies. Venture capitalists are said to be experienced at moving companies up the development path from the start-up stage, helping companies through problems that high-growth firms typically face when moving from prototype development to production, marketing, and distribution, using knowledge gained from prior experience with other investments in the portfolio (Black and Gilson, 1998). The following summarizes value-added activities venture capitalists most often provide to their portfolio companies:

1. Playing an active role on the board of directors (Sahlman, 1990; Aghion, Bolton, and Tirole, 2004; and many others).

2. Mentoring and being a confidant to the CEO (Sapienza, Manigart, and Vermeir, 1996). 
3. Professionalizing the company by locating and recruiting management and technical personnel (Salman, 1990; Black and Gilson, 1998; Hellmann and Puri, 2002); forming human resource policies and stock option plans; and replacing the founder with an outside CEO (Gomez-Mejia, Balkin, and Welbourne, 1990; Shalman, 1990; Hellmann and Puri, 2002).

4. Providing financial and business advice (Sapienza, Manigart, and Vermeir, 1996), including assistance on strategic, legal, accounting, technical, and operating issues and addressing weaknesses in the business model and the entrepreneurial team (Kaplan and Stromberg, 2004).

5. Networking (Sapienza, Manigart and Vermeir, 1996) and lending "reputational" capital to the firm, i.e., giving portfolio companies credibility to third parties (Sahlman, 1990; Black and Gilson, 1998; see II-3-2-4) thereby making it easier for the firm to access high quality professional assistance (e.g., lawyers, accountants, investment bankers, marketing experts) business partners (e.g., suppliers, customers, distributors), and other sources of funding, and to facilitate strategic alliances (Lindsey, 2005).

6. Helping with structuring an IPO or an M\&A (Sahlman, 1990), which includes ensuring strong governance structures at the time of the IPO (Hochberg, 2003). Venture capitalists have close ties to investment bankers who can assist companies going public or merging with other companies and facilitating contacts 
in large companies to which entrepreneurial ventures might be sold (Sahlman, 1990).

There is an extensive literature investigating how venture capitalists add value to their investee firms. For example, Gorman and Sahlman (1989) report that venture capital fund managers prototypically spend an average of half of their time monitoring an average of nine portfolio companies, of which five tend to be companies on whose boards they sit. Barry et al. (1990) and Sapienza, Manigart, and Vermeir (1996) find that venture capitalists add more value to portfolio companies when they have experience in the portfolio company's industry. ${ }^{28}$ Elango, Fried, Hisrich, and Polonchek (1995) identify significant differences in value-added activities across venture capitalists with different investment stages of interest. Calomiris, De Carvalho, and Amaro de Matos (2005) show that venture capitalists transfer information about senior managers of various entrepreneurial firms to each other, and use this network to locate and relocate managers.

Venture capitalists play a role in the operation of the portfolio company in order to add value, but also to control the firm. Venture capitalists operate in an environment of severe information asymmetry, making monitoring and control crucial tasks. The following discusses information asymmetry and considers how fund managers mitigate it.

\footnotetext{
${ }^{28}$ Sapienza and Korsgaard (1996) consider entrepreneur-venture capitalist relations, using procedural justice theory as a framework. Barney, Busenitz, Fiet, and Moesel (1996) examine how entrepreneurs evaluate venture capitalists' assistance. Gomez-Mejia, Balkin, and Welbourne (1990) report that venture capitalists' financial (e.g., helping to obtain additional investors) and networking contributions (e.g., obtaining competitive information, referring accountants, lawyers, consultants) are viewed positively by CEOs, but the managerial involvement (e.g., developing organizational structure and human resource management, monitoring the $\mathrm{CEO}$ ) is perceived negatively.
} 
1-1-5. Information Asymmetry ${ }^{29}$

A consistent view in the literature is that adverse selection and moral hazard problems caused by informational asymmetry are particularly acute in venture capital investments (Gompers, 1995). ${ }^{30}$ Since entrepreneurial firms typically lack assets to provide collateral and a "track record," the effects of informational asymmetry are more severe when investing in young growing firms than in financing established firms (Amit, Brander, and Zott, 1998). Moreover, the nature of entrepreneurial firms in which venture capitalists typically invest, (i.e., technology- and knowledge- based, research-intensive companies) requires specific skills and knowledge to monitor and manage (Hopp, 2006). ${ }^{31}$

${ }^{29}$ Cumming and MacIntosh (2002) point out four types of principal-agent relationships in the context of venture capital: (1) venture capitalists have incentives to favour their interests over those of their investors; (2) the entrepreneur has an incentive to favour his/her interests over those of the venture capitalist; (3) venture capitalists have the incentive to act at odds with the best interests of the entrepreneur; and, (4) the venture capitalist and other investors have incentives to favour their interests over the purchasers, when the venture capitalist exits the entrepreneurial firm. This dissertation suggests that agency problems may also exist among venture capitalists investing in a same entrepreneurial firm (i.e., those in a syndicate), and thus add two more principle-agent relationships. Agency problems may be present between: (1) the incumbent venture capitalists (who have already invested in the entrepreneurial firm) have incentives to favour their interests over the entrant; and (2) the lead venture capitalist has incentives to favour his/her interests over non-lead investors in the syndicate. This type of agency relationship is discussed by Admati and Pfleiderer (1994), Lerner (1994a), Wright and Lockett (2003), Kaplan and Stromberg (2004), Cumming (2006), Seppä and Jääskeläinen (2002), and will be reviewed in II-2-5-4.

Studies on venture capital investment consider agency problems in at least one of those six types of principal-agent relationships. Here, however, the discussion focuses on agency problems associated with the venture capitalist-entrepreneur relationship.

${ }^{30}$ Two forms of agency problems arising from information asymmetry are adverse selection and moral hazard (Amit, Brander, and Zott, 1998). "Adverse selection" occurs when one party to a transaction knows relevant information that is not known to the other party. "Moral hazard" is referred to a situation where one party to a transaction cannot observe relevant actions taken by the other party (or at last cannot legally verify these actions).

${ }^{31}$ There is a large theoretical literature on asymmetric information problems in the venture capital setting. For example, Amit, Glosten, and Muller (1990) consider the situation where venture capitalists are unable to evaluate adequately entrepreneurs' abilities to turn their ideas into viable enterprises, and examine how this affects entrepreneurs' decision to develop their ventures independently or with venture capitalists. Houben (2002) analyzes the case of double-sided adverse selection and double-sided moral hazard, i.e., 
The illiquid nature of venture capital investment makes it more challenging for venture capitalists to deal with informational problems, as it makes portfolio rebalancing difficult when new information about investee firms is revealed (Lockett and Wright, 2001). ${ }^{32}$ Moreover, it has been argued that venture capital portfolios may be under-diversified. Cumming (2002) reports that venture capital funds typically hold between two and 20 investments in their portfolios. Under-diversification may result from small fund size (Lockett and Wright, 2001), and venture capitalists' need and desire to closely monitor, maintain control, and add value to investee firms (see II-2-5-2). ${ }^{33}$ Those studies suggest that venture capitalists' ability to mitigate risk of information asymmetry though diversification might be limited.

As asymmetric information is viewed as so acute in venture capital investing, devices venture capitalists frequently use for their investments, including staged financing, syndication, convertible securities, etc., are considered means of mitigating this type of problem. Indeed, there is a view that venture capitalists are financial intermediaries who have developed various skills and strategies for dealing with severe information asymmetry (Amit, Brander, and Zott, 1998). The followings (1-1-6, 1-1-7, and 1-1-8) review in more depth the literature on investment devices frequently used by venture

both the entrepreneur and the venture capitalist have private information and an incentive to overstate the information each privately possesses. A thorough review of this literature is beyond the scope of this dissertation; however, this dissertation will review some parts - mainly those related to syndication and exit practices.

${ }^{32}$ The reverse is also true: asymmetric information associated with privately held firms is one factor causing illiquidity of those firms (Sahlman, 1990).

${ }^{33}$ Lockett and Wright (2001) argue that information asymmetry prevents venture capital portfolios from fully diversifying, as it is difficult to grasp the risk characteristics of potential investee companies before investing. 
capitalists and consider how those tools are thought to mitigate asymmetric information problems.

\section{1-1-6. Contracts $^{34}$}

Because venture capitalists operate in an environment of severe information asymmetry and high level of uncertainty they have strong incentives to monitor and control their portfolio companies (Black and Gilson, 1998). Accordingly, venture capitalists structure agreements that call for their representation on the investee company's board of directors (Sahlman, 1990). ${ }^{35}$ Venture capital-backed high-technology firms are characterized by boards of directors that have high levels of power relative to those of management (Rosenstein, 1988). Board control gives the venture capitalist the power to replace the original founder from the position of the CEO if performance lags (Black and Gilson, 1998), presenting founders with strong incentive to perform (Cumming, 2002). ${ }^{36}$ Empirical evidence suggests that venture capitalists have stronger control when the uncertainty about the investee firm is higher and thus monitoring and control are more

\footnotetext{
${ }^{34}$ There is a substantial theoretical literature on venture capitalist-entrepreneur contracts (e.g., Hellmann, 1998; Cestone, 2002). See Kaplan and Stromberg (2003) for review.

${ }^{35}$ According to Kaplan and Stromberg (2003, see Table 2), venture capitalists maintain approximately 40 percent of the board seats in their investee firms on average.

${ }^{36}$ It appears that venture capitalists frequently replace the entrepreneur as the CEO (Rosenstein, 1988; Gorman and Sahlman, 1989; Fried and Hisrich, 1995). Rosenstein, Bruno, Bygrave, and Taylor (1989, cited in Fried and Hisrich, 1995) report that 40 percent of the high-performing companies and 74 percent of low-performing companies have changed CEOs at least once. Hellman and Puri (2002) find that venture capital-backed companies are also more likely and will act faster to replace the founder with an outside CEO, in both adversarial and mutually agreed situations. Hellmann (1998) provides a theoretical framework on venture capitalists' right to fire entrepreneurs.
} 
important (Kaplan and Stromberg, 2003; Lerner, 1995). Kaplan and Stromberg argue that when uncertainty is high, conflicts are more likely to arise between the venture capitalist and the founder, over such issues as whether the manager should be replaced or the business should be continued. Venture capitalists therefore structure investment contracts in ways such that terms and conditions ensure their control over investee firms in these instances. According to Kaplan and Stromberg (2003), contracts between venture capitalists and an entrepreneurial firm typically: ${ }^{37}$

- provide venture capitalists with rights to control roughly 50 percent of the cash flow and founders control 30 percent;

- provide venture capitalists with the majority of board seats (in 25 percent of all financing rounds, the founders in 14 percent of the cases, and neither in 61 percent of the cases $) ;^{38}$

- ensure venture capitalists liquidation rights by (1) employing securities for which claims in liquidation are senior to those of the founders (e.g., convertible

\footnotetext{
${ }^{37}$ There are a number of provisions often embedded in venture capital contracts. Discussion on each of those provisions is beyond the scope of this dissertation; see, Sahlman (1990) and Chemla, Habib, and Ljungqvist (2004).

${ }^{38}$ In general, the board is responsible for (1) hiring, evaluating, and firing top management; and (2) advising and ratifying general corporate strategies and decisions. Certain corporate actions (e.g., large acquisitions, asset sales, subsequent financings, election of directors) are governed or subject to shareholder votes. Board rights, voting rights, and cash flow rights can be different from each other. The difference is achieved through, for example, unvested stock options (which do not have votes), non-voting stock, contracts specifying a change in equity ownership at the IPO (i.e., at the point when the venture capitalist has pre-committed to giving up most control rights), or explicit contracting on the right to exercise votes depending on performance targets, explicit agreements on the election of directors (Kaplan and Stromberg, 2003). In fact, Kaplan and Stromberg argue that the distinguishing characteristic of venture capital financings is that they allow venture capitalists to separately allocate cash flow, board, voting, liquidation, and other control rights.
} 
preferred stock); (2) making the venture capitalist's claims in liquidation at least as large as the original investments; and, (3) making the preferred dividends cumulative;

- include provisions that give the venture capitalist the right to demand that the firm buy back the venture capitalist's claim after some period of time (present in $78.7 \%$ of the financing rounds), with a typical maturity of five years;

- bestows (under certain conditions) automatic conversion of the security held by the venture capitalist into common stock (present in 95 percent of financings);.

- affords anti-dilution protection against future financing rounds at a lower valuations than that of the current (protected) round (present in almost 95 percent of financings);

- grants vesting and non-complete clauses to the entrepreneur (to make it more difficult for him or her to leave). The former involves vesting the entrepreneur's shares over time (the company receives or can buy back any unvested shares for a low price if the entrepreneur leaves). The latter approach prohibits the entrepreneur from working for another firm in the same industry for some period of time if he or she leaves (vesting founders' share is used in almost 41 percent, and non-compete clauses are used in approximately 70 percent, of financings). ${ }^{39}$

\footnotetext{
${ }^{39}$ There are other rights frequently embedded in venture capital investment contracts. For example:
} 
Kaplan and Stromberg (2003) report that rights are frequently contingent in such a way that: (1) if the company performs poorly, the venture capitalist obtains full control; (2) if the company's performance improves, the entrepreneur retains/obtains more cash flow rights and control rights; (3) if the company performs very well, the venture capitalist retains his/her cash flow rights but relinquishes most of his/her control and liquidation rights. The contingencies work as mechanisms to align the entrepreneur's interest with that of the venture capitalist, and to ensure the venture capitalist's control over the firm when it is performing poorly. Moreover, while most venture capitalist-entrepreneur agreements call for regular transmission of information (including financial statements, budgets, operating statements, etc.) and permit the venture capitalist to inspect the company's financial accounts at will (Sahlman, 1990; Cumming, 2002), the presence of those contingencies further ensures that venture capitalists receive timely information. Kaplan and Stromberg (2003) report that contingent rights are especially common in first financing rounds and early stage financings.

Finally, contract terms as described above may be used by venture capitalists as a mechanism to sort out entrepreneurs. Sahlman (1990) argues that because such contract terms shift risk from the venture capitalist to the entrepreneur, only entrepreneurs who are

- Rights to first refusal, which gives the venture capitalists the right to refuse the proposal in which the portfolio company offer equity securities to any person to purchase up to a 50 percent of such shares (Cumming, 2002).

- Pre-emptive right, which entitles the venture capitalist to participate in new financings by buying newly-issued shares from the company, often in proportion to their common-stock-equivalent holdings before the issuance of new equity-equivalent shares (Sahlman, 1990).

Rights of first refusal and pre-emptive rights enable (or make it easier for) venture capitalists to invest more (Sahlman, 1990). 
truly confident of their abilities and deeply committed to their businesses would accept them. The entrepreneur's response to those terms enables the venture capitalist to make informed evaluation and judgments. ${ }^{40}$

\section{1-1-7. Securities Used}

Studies of American venture capital consistently document that convertible preferred equity is the financial instrument of choice (e.g., Sahlman, 1990; Black and Gilson, 1998). Convertible preferred gives the holder both a senior claim on remaining assets if the investee firm fails and a claim on residual cash flows when the investee is successfully sold or taken public. Moreover, convertible preferreds typically have automatic conversion provisions, which automatically convert the security held by the venture capitalist into common stock under certain conditions. ${ }^{41}$ Automatic conversion provisions provide the entrepreneur an incentive to perform, enabling venture capitalists to mitigate at least a part of asymmetric information problems (Kaplan and Stromberg, 2003; Cornelli and Yosha; 2003), maintain better control of portfolio companies (Kalay and Zender, 1997; Kaplan and Stromberg, 2003; Repullo and Suarez, 2004; Bascha and

\footnotetext{
${ }^{40}$ Kaplan and Stromberg (2003) find that the cash flow rights, control rights, and contingencies are used more as complements than as substitutes. For example, a company in which the venture capitalist has voting and board majorities is also more likely to have the entrepreneur's equity claim and the release of committed funds contingent on performance milestones. Cumming (2002) finds similar results in Europe.

${ }^{41}$ Kaplan and Stromberg (2003) report that a median automatic conversion provision requires that the company complete an IPO at an IPO stock price three times greater than the stock price of the financing round, which means that median venture capitalists are not willing to give up control unless they triple their money.
} 
Walz, 2001; Schmidt, 2003; and Casamatta, 2003' Berglof, 1994; Hellmann, 2002; Bratton, 2002), and better align interests of entrepreneurs and investors (Marx, 1998). In addition, participating features are also generally attached to convertible preferreds, which put the venture capitalist in a position equivalent to having preferred stock and common stock, rather than holding convertible preferred only, upon the liquidation or exit prior to conversion. This enables venture investors to share in dividends and liquidations as both a preferred and a common shareholder, if the proceeds exceed the amount of the preference. Therefore, many of the theoretical studies on the use of convertible preferred in venture capital setting view that it is the optimal form of investments in venture capital financing. Kaplan and Stromberg (2003) report that convertible preferred was used in 204 out of 213 financing rounds in their sample, with a participation feature in 82 of the rounds.

However, convertible preferred is not the most frequently used security in countries outside the United States (Cumming, 2002; Schwienbacher, 2005; Kaplan, Martel and Stromberg, 2004). Lerner and Schoar (2005) analyze developing country private equity investments, and document that investments in high legal enforcement and common law nations often use convertible preferred stock with covenants, while in low enforcement and civil law nations, private equity groups tend to use common stock and debt. In Canada, Cumming (2005a, 2005b, 2005c) documents that a variety of securities are used, and convertible preferred equity is not the most frequently used. Further, Cumming, $(2005 \mathrm{a} ; 2007 \mathrm{~b})$ reports that convertible preferred equity is not the most frequently-used 
security employed by American venture capitalists financing Canadian entrepreneurial firms.

It is not clear why convertible preferred is the most widely used security in the United States, but not in other countries. Explanations of this difference include: (1) lack of contract sophistication in countries outside the United States (Schwienbacher, 2005); ${ }^{42}$ (2) differences in industry structure (Schwienbacher (2005) notes that European venture capitalists are significantly more likely to be affiliated with a corporation, while the American market is dominated by private independent limited partnerships); (3) differences in preference of investment styles between American venture capitalists and others (Cumming (2002) observes that European venture capitalists regard simplicity as an important aspect of the deal as complicated payoff structures do not facilitate room for negotiation with potential syndicate partners, and entrepreneurs are often dissuaded by excessively complicated finance arrangements).

On the other hand, Gilson and Schizer (2003) question the validity of theoretical frameworks that show convertible preferred as the most advantageous choice, suggesting an alternative explanation for the pervasive use of convertible preferred by American venture capitalists in the American investment setting. They attribute the widespread use of convertible preferreds to United States' tax practice, which offers relatively favourable

\footnotetext{
${ }^{42}$ Schwienbacher (2005) finds that in both Europe and the United States, younger venture capital firms use convertible securities less often than established ones. He reports some practitioners' comments that during the boom in which lots of money was chasing a few good deals, many venture capitalists, especially younger ones, agreed to join syndicates at less favourable terms, e.g., by accepting common shares instead of convertible preferred stock.
} 
tax treatment for incentive compensation paid to the entrepreneur and other employees. ${ }^{43}$ This argument offers an explanation not only for why convertible preferred is so commonly used in the United States, but also why it is not utilized outside the United States (such tax benefits may not exist outside the United States). However, because empirical evidence supporting Gilson and Schizer's tax explanation has not yet been advanced, it is still not entirely clear why convertible preferred equity is so pervasive in the United States but not in other countries. ${ }^{44}$

\section{1-1-8. Staged Investment}

Venture capitalists usually make their financings in stages, rather than providing up front all the capital that the portfolio company requires to accomplish its business plan. Stages usually coincide with meaningful steps in the development of the entrepreneurial firm, such as a demonstration of technology or a successful product introduction (Sahlman, 1990; Neher, 1999; Repullo and Suarez, 2004; and Fluck, Garrison, and Myers, 2005; among others). Contract terms are determined by bargaining at each stage (Fluck, Garrison, and Myers, 2005). Moreover, at each stage, the venture capitalists have an option to stop financing (Sahlman, 1990). Staged financing is suited for situations where

\footnotetext{
${ }^{43}$ Instead of being taxed at ordinary income tax rates, the entrepreneur and employees can defer tax until the incentive compensation (e.g., stock option) is sold, at which point the capital gain tax rate is available.

${ }^{44}$ The other explanation is that convertible preferred shares have become the most widely used securities because of the already highly standardized purchase agreements available in the United States. This implies low legal costs relative to not yet standardized contracts, which may be very expensive to write.
} 
the information on the investee firm's prospects arrives sequentially as is true of venture capital investments.

At each stage of financing, venture capitalists gather information and re-evaluate the portfolio company in order to decide if they will provide additional funding. Thus, staged financing gives the entrepreneur an incentive in the form of a hard constraint (Black and Gilson, 1998). Also, the entrepreneur must produce the intermediate result in order to receive continued financing, which reduces his/her incentives to procrastinate in the intermediate periods and limits the scope of potential moral hazard (Bergemann and Hege, 1998). Staged financing is, therefore, generally viewed as a mechanism that allows venture capitalists to monitor portfolio companies closely and mitigate agency problems. Moreover, it gives venture capitalists a strong control lever (Black and Gilson, 1998). The right to abandon the portfolio company allows venture capitalists not only to avoid investments of which prospects look dim, but also to discipline disobedient managers by firing or demoting them (Sahlman, 1990).

Consistent with the above view, Gompers (1995) finds that the duration between two consecutive financing stages is shorter for entrepreneurial firms associated with more severe agency problems (younger firms, those in industries characterized by greater asset intangibility, higher R\&D intensities, or higher market-to-book ratios). ${ }^{45}$ Kaplan and

\footnotetext{
${ }^{45}$ Several theoretical frameworks consider staged financing arrangements in venture capital investments. For example, Chan, Siegel, and Thakor (1990) consider an agency model in which one contracting party's (the entrepreneur's) skill is unknown to both at contract signing but the arrival of information reveals this skill to both parties and is used to determine who controls second period production. Their model explains
} 
Stromberg (2003) report that time between rounds is longer when the firm is managed by a previously-successful repeat entrepreneur. They also report that more funds are provided up front: (1) when the firm is managed by a repeat entrepreneur; (2) when the round return is higher; and, (3) as the venture capitalist-founder relationship progresses.

\section{1-1-9. Summary}

Venture capitalists provide capital to young, privately held companies that have high growth potential. They invest in those companies when firms are very young and lack positive earnings and cash flows, and hold their interests until those companies become mature and profitable, at which point venture capitalists exit and harvest returns. Thus, venture capital investments are long-term, illiquid investments (Cochrane, 2001). Venture capitalists are value added investors, actively involved in managing funded firms, providing assistance in many aspects of those firms' operations.

Venture capitalists operate in an environment where asymmetric information is severe and uncertainty is high. The illiquid and under-diversified nature of their portfolio makes it challenging for venture capitalists to tackle those problems. In order to mitigate asymmetric information problems and reduce uncertainty, venture capitalists have developed various mechanisms, which include security and contract design, as well as staged investments.

why venture capital contracts contain explicit covenants permitting passage of control to the venture capitalists following a poor performance by the entrepreneur. 
The next subsection discusses the characteristics of the Canadian venture capital industry.

\section{1-2. The Canadian Venture Capital Industry}

This subsection discusses the characteristics of the Canadian venture capital industry in terms of its size (1-2-1), sector, stage, and regional distributions (1-2-2), types and sources of funds (1-2-3 to 1-2-4). In addition to limited partnerships, Labour-Sponsored Venture Capital Corporations (LSVCCs) are unique to Canada; their mechanism and the impact of their presence on the market are reviewed in II-1-2-5. Other oft-debated issues about the Canadian industry (potential shortage of skilled fund managers, weak entrepreneurial base, and low rate of returns) are discussed in sections 1-2-6, 1-2-7, 1-28 , respectively.

\section{1-2-1. The Size}

On an absolute basis, the venture capital industry in Canada is much smaller than that in the United States. Between 2003 and 2006, the American venture capital industry invested $\$ 25-30$ billion $C D N$ in 2,000 to 3,000 entrepreneurial firms per year, while the Canadian industry annually invested $\$ 1.5-2$ billion CDN in 400-650 companies (Thomson Financial, 2007, pp. 11-12). The level of venture capital investments has been decreasing in both Canada and the United States. In 2009, the Canadian venture capital 
sector invested in total $\$ 1.0$ billion CDN (decrease of 27 percent from $\$ 1.4$ billion CDN invested in 2008) in 331 companies (15percent below the 388 companies financed in 2008). In the same year, American funds invested $\$ 17.7$ billion US (in 2368 firms), which is $37 \%$ below the US $\$ 28.0$ billion invested in 2008 (Thomson Financial, 2010).

The level of fund-raising has also been decreasing in Canada and the United States. In Canada, the total amount of new commitments to venture capital funds was $\$ 1.2$ billion CDN in 2007, $\$ 1.0$ billion CDN in 2008, and $\$ 995$ million CDN in 2009. In the US, it was $\$ 37.2$ billion CDN in 2007, $\$ 28.6$ billion US in 2008 and $\$ 15.2$ billion US in 2009 (Thomson Financial, 2010).

Until mid-2000s, on a relative basis, the Canadian venture capital sector is comparable to that of the United States and larger than those of other G7 countries. Bygrave and Quill (2007, p. 16) report that venture capital investment as a percentage of GDP was about 0.13 percent for Canada, 0.175 percent for the United States, and the G7 average was 8.6 percent. However, the flow of venture capital investment in Canada has been decreased to 0.1 percent of GDP, less than one half of the level in the United States in 2009 (Thomson Reuters, 2010).

Historically, the Canadian venture capital sector experienced significant growth in the late $1990 \mathrm{~s}$ and the early $2000 \mathrm{~s} .{ }^{46}$ As a result, the industry is still relatively young. As of 2002, the average venture capital firm in Canada was five years old, compared with 11

\footnotetext{
${ }^{46}$ As of 2002, there are 282 venture capital funds in Canada and 1798 funds in the United States. The number of funds also increased in the United States between 1996 and 2002 (Industry Canada, 2004).
} 
years old in the United States (Industry Canada, 2004). During the past two years, however, venture capital activities in Canada have been declining: the levels of venture capital investments and fund-raising activities have continued to approximate levels recorded in the mid-1990s (Thomson Financial, 2010).

Riding (2006b) points out that the Canadian industry is characterized by a relatively large number of small funds (see Figure I-1, Table I-1). The majority of Canadian venture capital funds hold less than $\$ 100$ million in total capitalization, and the few relatively large funds are mostly government or government affiliated (e.g., LSVCCs and the BDC) rather than private independent funds. Riding argues that this type of industry structure has an advantage - it facilitates early-stage investments - as smaller funds often specialize in the early stages and provide considerable non-financial value-added. On the other hand, it also has a negative consequence: the amount of capital that each fund can allocate to any one investment may be limited, especially when the fund needs to be prudently diversified. A syndicate comprised of a large number of small funds may become necessary in order to provide sufficient capital to a successful investee), but such a syndicate structure is costly and inefficient.

Another characteristic of the Canadian industry is its deal size. Canadian venture capital funds invest substantially smaller amounts than their American counterparts in each of their portfolio companies. For example, in Canada, the average amount invested per company was $\$ 3.3$ million CDN in 1999 , $\$ 5.0$ million $\mathrm{CDN}$ in 2007 , and 3.1 million CDN in 2009; in the United States $\$ 18.2$ million CDN in $1999, \$ 9.9$ million CDN in 
2007, and \$8.5 million CDN in 2009 (Thomson Financial, 2007; p.14, 2008, p.5, 2009, p.14). This is possibly a consequence of small fund size discussed above. Riding (2006b) argues that total investment is a competitiveness issue since Canadian firms must compete with their better-funded American counterparts and typically in the American product market (in order to achieve the growth required to generate rates of return required by the venture capital investors).

\section{1-2-2. Sector, Stage, and Regional Distributions}

Venture capital is generally characterized as capital for high-risk, high-return investments, and thus is concentrated in high-technology entrepreneurial firms. Canada is not an exception. Of the $\$ 2.079$ billion CDN of total venture capital investments in 2006 , 51 percent was placed in information technology firms; 30 percent in biopharmaceutical and other life science companies; 10 percent in energy, environmental, and other technology firms; 9 percent in firms in traditional sectors (products and services, manufacturing, etc.). In 2009, 48 percent were in information technology, 21 percent were in biopharmaceutical and other life science companies, 11 percent in energy, environmental, and other technology oriented, and 19 percent in traditional sectors (Thomson Reuters, 2009).

For the period between 2002 and 2005, 53 percent of venture capital backed firms were early stage, in which 49 percent of dollars were invested (Duruflé, 2006). In 2009, 45 
percent were early stage, in which 49 percent of dollars were invested (Thomson Financial, 2010). This early stage focus is probably a consequence of the Canadian venture capital market being comprised of a larger number of small funds. It is difficult to determine whether such a focus is a weakness or strength. Industry Canada (2004), therefore, offers two assessments: (1) Canadian industry offers more support than does the American industry for early-stage firms, which tend to be disadvantaged in accessing venture capital (good news); and, (2) Canada's smaller venture capital industry may not have the capacity to finance later-stage firms. ${ }^{47}$ Duruflé (2006) provides evidence supporting the latter conclusion: during the period between 2002 and 2005, the average amount financed for an early stage deal in Canada was half of that in the United States, and the average amount financed to a later stage deal in Canada was a quarter of that in the United States. ${ }^{48}$

Canadian venture capital investments tend to focus on follow-on investments. ${ }^{49}$ Between 2001 and 2006, the proportion of new investments to total venture capital investments (dollar value) varied around the 25 percent level (Thomson Financial, 2007, p.22). In

\footnotetext{
${ }^{47}$ It is difficult to determine the appropriate level of investment that should be placed in early stage firms, as it is difficult to calculate the demands for early and later stage capital.

${ }^{48}$ This early stage concentration is being moderated. In 2007 , about 42 percent of venture capital-backed companies are early stage, where one-thirds of dollar invested is placed (Thomson Reuters, 2008). Although the difference in deal sizes between Canada and the United States is narrowing, it is still present: in 2006, the average amount financed to an early stage deal in Canada is 62.5 percent of that in the United States, and the average amount financed to a later stage deal in Canada is 41.7 percent of that in the United States (Duruflé, 2007).

${ }^{49} \mathrm{~A}$ follow-on investment is a supplementary round of financing in a portfolio company that builds on its original financing, generally in line with business growth and development (CVCA, http://www.cvca.ca/resources/glossary.aspx, accessed Oct. 19, 2009). Venture capital-backed companies are often engaged in multiple follow-on financings (see II-1-1-8, "staged investment").
} 
2009, the proportion was 31 percent: Of 331 companies that received venture capital, 146 (44 percent) obtained it for the first time (Thomson Financial, 2010).

Regarding the regional distribution in Canada, Ontario has been the largest market in Canada, followed by Quebec and British Columbia. Between 2005 and 2007, 40 to 45 percent of venture capital investments were placed in Ontario and 30 to 35 percent in Quebec. ${ }^{50}$ However, in terms of fundraising, Quebec has been the most active province, accounting for 50 to 70 percent of the total new capital commitments from 2003 to 2007, while Ontario represents 15 to 35 percent of total fundraising activity (all based on dollar value, Thomson Financial, 2008, pp.12, 17). ${ }^{51}$ It is interesting to note that Ontario tends to have greater dollar amounts invested than amounts raised, while in Quebec amounts raised tend to be greater than amounts invested. This may be explained by several facts including that: (1) Quebec is the province where government-affiliated LSVCCs (Labour Sponsored Venture Capital Corporations) are the most active (Industry Canada, 2004); ${ }^{.2}$ and, (2) Ontario is the province where foreign capital is most drawn. In 2007, about $\$ 500$ million CDN was invested in Ontario by foreign funds, representing 53 percent of total foreign funds' investments in Canada (Thomson Financial, 2008. p.13).

\footnotetext{
${ }^{50}$ However, the share of the total amount invested accounted for by Ontario decreased to 28 percent, while the share of Quebec increased to 43 percent (Thomson Financial, 2010)..

${ }^{51}$ In 2009, the share of the total amount raised accounted for by Ontario was 32 percent, the share of Quebec was 38 percent (Thomson Financial, 2010).

${ }^{52}$ For example, of $\$ 907$ million CDN raised by LSVCCs in 2006, 85 percent took place in Quebec (Thomson Financial, 2007). See also II-1-2-3.
} 


\section{1-2-3. Types of Funds}

The Canadian Venture Capital Association (CVCA) classifies venture capital funds into six types based on the sources of contributed funds:

- Private independent limited partnerships are professionally managed funds that raise capital from institutional investors (insurance companies, pension and mutual funds) and wealthy individuals. Cumming (2005c) notes that Canadian private independent funds generally have fewer and less restrictive covenants placed on investment managers than their American counterparts.

- Corporate funds are private equity funds that are divisions or subsidiaries of financial or industrial firms (e.g., Siemens Venture Capital, Motorola Venture Capital). ${ }^{53}$

- Government funds are those organized through a federal or provincial agency or crown corporation (e.g., Business Development Bank of Canada). ${ }^{54}$

- Retail Funds are funds established with the benefit of government tax credits to individuals. This category comprises Provincial Venture Capital Corporations and

\footnotetext{
${ }^{53}$ While private independent and corporate funds are sometimes put in the same category called "private" funds, they could be very different. See Siegel. Siegel, and Macmillan (1988), Gupta and Sapienza (1992), Wang, Wang and Lu (2002), and Maula, Autio, and Murray (2005).

${ }^{54}$ There are few government funds in Canada. Those funds may behave differently from "private" funds, as governments are less concerned to make profits than to strengthen the entrepreneurial sector: such actions include effecting a buyback exit even when a more advantageous form of exit is available (Cumming and MacIntosh, 2002).
} 
LSVCCs (see II-1-2-5). ${ }^{55}$ Retail funds dominate the Canadian Venture capital industry, with LSVCCs controlling approximately half of the venture capital under management in Canada and significantly more than any other category of fund (Cumming and MacIntosh, 2002).

- Foreign investors include non-Canadian private equity funds or corporations active in Canada. They invest significant amounts of venture capital in Canadian entrepreneurial firms and most are American-based (Cumming and MacIntosh, 2006).

- Institutional investors, notably public pension funds, sometimes have in-house programs to make direct venture capital investments (Cumming and MacIntosh, 2006)..$^{56}$

Thomson Financial (2010, pp. 15) reports the share of funds invested for each fund type between 2004 and 2009. Approximately 20 percent of investments were made by private independent funds, five percent by corporate funds, ten percent from government funds, 25 percent from retail investors and one to six percent from institutional investors.

Foreign investors' participation has been increasing dramatically. Industry Canada (2004) reports that foreign investments grew by more than 2000 percent between 1996

\footnotetext{
${ }^{55}$ Schwienbacher (2005) finds, in Europe, that affiliated venture capitalists tend to be less often represented on boards and require less reporting from entrepreneurs, and that closed-end funds syndicate more and have shorter round durations. He interprets those results as indications that affiliated venture capitalists may be less active in their portfolio companies than independent venture capitalists, and closed-end funds tend to be more active than other types.

${ }^{56}$ For differences in investment behaviours across different types of funds, see Cumming (2005c, 2006).
} 
and 2002, a period in which the industry as a whole experienced 139 percent growth of venture capital investment. ${ }^{57}$ According to Thomson Financial (2008, pp. 6, 7), investments by foreign (principally American) venture capital funds rose from just under $\$ 400$ million CDN in 2003 to about $\$ 850$ million $C D N$ in $2007 .{ }^{58}$ Consequently, the share of foreign funds (in terms of dollar invested) also grew from about 23 percent in 2003 to 41 percent in $2007 .^{59}$

Duruflé (2006) reports that foreign investors are present at all stages except seed. Between 2002 and 2005, 44 percent of total dollars invested by foreign investors were placed in early stages and 56 percent in later stages. ${ }^{60}$ Foreign investments represent three percent of total seed capital investments, 29 percent of investments at the start-up stage and 22 percent at the other early stage, and 31 percent at the expansion stage. Their representation is smaller when viewed in terms of number of deals: they participated in six percent of the total number of deals at the seed, 11 percent at the start-up, 14 percent at the other early stage, and 12 percent at the expansion stages. This suggests that foreign investors provide a larger amount of capital per deal. ${ }^{61}$

\footnotetext{
${ }^{57}$ Over the same period, government funds' investments grew by 433 percent, private independent funds by 58 percent, LSVCCs by 53 percent, institutional investors by 15 percent, corporate funds by 34 percent.

${ }^{58}$ More than half of foreign capital is drawn to Ontario, and most of the rest is to Quebec and British Columbia.

${ }^{59}$ In 2009 , foreign funds invested $\$ 306$ million CDN, 30 percent of the total venture capital investment in Canada.

${ }^{60}$ This percentage is more resemble to Canadian percentage ( 49 percent in early stage) than American's (19 percent), and thus Duruflé argues that the breakdown may reflect the structure of the Canadian deal flow (not very many companies are grown to later stages).

${ }^{61}$ In 2006, foreign investors participate in 14 percent at start-up, another 14 percent at the other early stage, and 20 percent of later stage deals (in terms of number of financing rounds, Duruflé, 2007).
} 
Industry Canada (2004) expresses a concern that foreign investment (which comes primarily from the United States) may pressure Canadian investee companies to move to the United States either directly or through mergers and acquisitions. ${ }^{62}$ If so, the reliance on foreign capital would result in not only the loss of successful or promising companies, but also the loss of benefits from the longer term growth of these companies, particularly if they were to grow into world-class leaders in their industries. ${ }^{63}$

Another defining characteristic of the Canadian industry is the relatively low participation of private independent funds and the relatively high participation of retail funds (LSVCCs). LSVCCs funds are especially concentrated in Quebec where LSVCCs accounted for 83 percent of funds raised (39 percent for the rest of Canada, Duruflé, 2006). Industry Canada (2004: 159) sees the relative low activity of private funds as a matter of concern, arguing that:

[t]o ensure the sustained development and growth of the Canadian venture capital industry, and to provide a significant proportion of venture capital investment, private independent funds must continue to grow and expand their fund-raising activities". For this to happen, these funds must be able to attract more capital from institutional and foreign investors, as is the case in the United States.

\footnotetext{
${ }^{62}$ According to Industry Canada, some of the Canadian companies funded by American investors, most of which depend on the American market to sell their products and to find experienced management personnel, find it easier to expand their markets by moving the entire company or some of its decisionmaking components to the United States. Such practices benefit American venture capitalists by easing the process of value-added support and by streamlining exit opportunities.

${ }_{63}$ This negative impact would be reduced if American investors, such as pension funds, invested in Canadian venture capital funds (rather than making direct investments in Canadian entrepreneurial firms) or invested as part of a syndicate in which the Canadian fund maintained some control.
} 
However, an important barrier to the participation of private venture capital firms is the low level of funding provided to them by institutional investors.

\section{1-2-4. Sources of Funds}

Institutional investors (pension funds, insurance companies, and endowments) are the major sources of funds for venture capital funds in the United States. In Canada, however, financial institutions have not played an active role. ${ }^{64}$ In 2002 , for example institutional investors accounted for 89 percent of new capital raised in the United States venture capital sector but only for 18 percent in Canada (Industry Canada, 2004). Between 2002 and 2005, 63 percent of total fundraising in Canada was accounted for by contributions from individual investors, 19 percent from Canadian institutional investors, five percent from foreign investors, and ten percent from governments (Duruflé, 2006). ${ }^{65}$

Falconer (1999) and Macdonald \& Associates (2004) identify impediments to pension funds' asset allocations to venture capital, obstacles that appear to reside in both the venture capital market and the regulatory environment. Impediments include:

1. Costs associated with deal selection, due diligence, monitoring, and evaluation.

\footnotetext{
${ }^{64}$ For international comparison of sources of venture capital funds, see Mayer, Schoors, and Yafeh (2005).

${ }^{65}$ The breakdown of fund sources is, however, quite different for private independent funds: 59 percent from Canadian institutional investors, 20 percent from foreign investors, seven percent from governments. With this figure, involvement of all institutional investors in Canada is still lower than those in the United States, and what venture capital investment that institutions do make is often at the upper end of the "private equity" spectrum, notably Ontario teachers' pension fund's direct investment in the BCE buyout.
} 
2. Insufficient familiarity with, or support for, venture capital investment activity among trustees, sponsors and pension fund managers.

3. Lack of market infrastructure, such as reliable advisors, specialists and agents (e.g., gatekeepers) and pooling vehicles (e.g., fund of funds, a pool of institutional assets managed by professionals).

4. Limited availability of information with which pension managers can make investment decisions and monitor performance, such as long-term risk-adjusted return data (see II-1-2-8).

5. Difficulty in portfolio rebalancing due to the illiquid nature of investments and lack of universally recognized standards for financial performance (valuation practices vary widely across venture capital funds and in some cases lack clarity and transparency).

6. Concerns about performance and a perception that such high-risk investment activity is inconsistent with fiduciary responsibilities to pension plan members. In part, this concern relates to the possibility of high profile failures and liabilities, low returns, and a perception that there are not enough high quality entrepreneurial firms to warrant pension fund participation. This is fed, in part, from negative experiences during the 1980s when many pension funds first made capital commitments to private equity funds, which resulted in poor returns and conflicts with investment professionals. In contrast, Macdonald \& Associates' 
(2004) report that American institutional investors have developed confidence in the ability of private equity investments to deliver superior returns and diversification benefits over the long term.

7. Concerns about the possibility of misalignment between pension funds' (potential general partners) and limited partners' interests in private equity funds.

8. The tax and regulatory environment (e.g., the tax definition of limited partnerships views such partnerships as foreign property unless otherwise specified).

9. Concerns that high-risk investment activity may violate the spirit of government prudential regulations. ${ }^{66}$

In the United States, Lerner, Schoar, and Wong (2005) provide evidence that financial institutions have benefitted from investments in venture capital. Their findings suggest that the presence of experienced limited partners facilitates a better resource allocation in, and, therefore, the growth of, the venture capital industry.

\footnotetext{
${ }^{66}$ In the United States, Gompers and Lerner (1999a) report that the Department of Labor's clarification of the Employment Retirement Income Security Act's (ERISAs) "prudent man" rule (in 1979) had strong positive effect on contributions to venture capital funds by pension funds. Through 1978, the rule stated that pension fund managers had to invest with the care of a "prudent man," so that many pension funds avoided investing in venture capital entirely, as it was felt that a fund's investment in an entrepreneurial firm could be seen as imprudent. In early 1979, the Department of Labor ruled that portfolio diversification was a consideration in verifying the prudence of an individual investment (i.e., investments would be judged prudent, not by their individual risk, but by their contribution to portfolio risk). Therefore, the ruling implied that an allocation of a small fraction of a portfolio to venture capital funds would not be seen as imprudent, and opened the door for pension funds to invest in venture capital.
} 
Industry Canada (2004) and the CVCA (Macdonald \& Associates, 2004) recognize the low participation of institutional investors (particularly pension funds) in Canada as a problem to be addressed. Industry Canada (2004: 158) states that "[G]iven the importance and size of institutional investors, and based on the American experience, the growth and vitality of the Canadian VC industry will depend on the increased participation of institutional investors and private independent funds". To achieve this, it is important to demonstrate the industry's ability to deliver attractive returns to those investors; however, returns to venture capital investment has been low in Canada. Duruflé (2006), therefore, suggests that a significant enlargement of Canadian institutional funds base may be difficult and that private independent funds' increased funding would have to come from foreign sources, governments, and to a lesser extent, Canadian institutional funds. Moreover, Cumming and MacIntosh (2006) suggest that the presence of LSVCC funds may lead institutions to shy away from venture capital investments. This point is discussed in the following section.

\section{1-2-5. Labour Sponsored Venture Capital Corporations}

One of the major characteristics of the Canadian venture capital industry is the presence of "Labour Sponsored Venture Capital Corporations (LSVCCs)." LSVCCs draw their funding from individuals who receive substantial front-end tax credits for investing in an LSVCC. LSVCCs are classified as "retail funds" by the Canadian Venture Capital 
Association because they operate like a mutual fund. The major goal of the LSVCC programs is the expansion of the aggregate pool of venture capital in Canada to foster the growth of small- and medium-sized firms (Cumming and MacIntosh, 2006).

Many governments have launched programs that seek to promote venture capital financing (Gilson, 2003; Lerner, 1999, 2002; Leleux and Surlemont, 2003; Cumming, 2007a). Keuschenigg (2004a, b) and Keuschenigg and Nielsen (2001, 2002, and 2003) present theoretical treatments of government and tax policy towards venture capital. LSVCCs are a particular form of government subsidization of venture capital, created pursuant to special legislation of the federal government and of the five provinces that have passed enabling legislation for such funds (Cumming and MacIntosh, 2001a, 2002)..$^{67}$ LSVCCs are characterized as follows (Cumming and MacIntosh, 2001a, 2002, 2006):

1. Unlike private independent limited partnerships, LSVCCs are set up as corporations and so they are perpetual. Hence, their managed funds are structured as open-ended mutual funds and are subject to investor redemptions.

2. An LSVCC must have a labour union as sponsor. ${ }^{68}$ The union nominally controls the fund yet its substantive involvement is often only to 'rent' its name to the fund in return for a fixed fee or a small percentage of net asset value ("rent-a-union"

\footnotetext{
${ }^{67}$ Provincial LSVCCs are not permitted to operate in Alberta, and federal LSVCCs are not permitted to operate in Quebec, British Columbia, and Alberta (Cumming and MacIntosh, 2006).

${ }^{68}$ The union holds a class of shares in the fund that does not receive dividends and is not entitled to share in the assets upon winding up, but it is entitled to elect a majority of the directors (all jurisdictions require that it appoint a majority of the board).
} 
funds). The professional managers hired under contract by the union manage the fund's operations more-or-less autonomously. In many cases, the impetus to establish a fund comes from the company that will manage the fund, not from the union sponsor.

3. Funds are capitalized exclusively by the contributions of individuals and most LSVCC contributions are made through the vehicle of a registered retirement savings plan.

4. Contributions have largely been induced by generous tax benefits to investors both by the federal and participating provincial governments (contributions made through an RRSP receive additional tax benefits).

Tax benefits attached to LSVCCs have induced a large flow of funds from individual investors into LSVCCs. LSVCCs have enjoyed enormous growth since their introduction in the 1980 s, accounting for 25 to 50 percent of the new capital raised by the industry every year over 1992-1995 period (Cumming and MacIntosh, 2001a). In 2007, when private independent funds raised $\$ 447$ million $\mathrm{CDN}$, the amount of new capital commitments raised by LSVCCs was $\$ 741$ million CDN, which accounted for 62 percent of venture capital fundraising in Canada (Thomson Financial, 2008). ${ }^{69}$ LSVCCs have been the dominant form of venture capital firm in Canada since the early 1990s (Cumming and MacIntosh, 2006; Brander, Egan, and Hellmann, 2008).

\footnotetext{
${ }^{69}$ The difference has, however, narrowed. In 2003 , the amount of new capital commitments was $\$ 1,486$ million CDN for LSVCCs, while $\$ 276$ million CDN for private independent funds.
} 
The role of LSVCCs has been under considerable debate. First, there are questions with respect to whether LSVCCs have been effective in expanding the pool of venture capital. Kanniainen and Keuschnigg $(2003,2004)$ suggest that there is a trade-off between the number of companies and the value of managerial advice. They conclude that a rapid expansion of the venture capital industry may cause a scarcity of skilled venture capitalists and a consequent dilution of quality of advice received by entrepreneurial firms (at least in the short-run). To this point, Cumming and MacIntosh (2006, 2002, 2001a) also argue that the rapid influx of capital into LSVCCs resulted in many of these funds hiring inexperienced managers. They report that some LSVCC funds hired graduates directly from MBA programs to work as venture capital managers.

Second, there is an argument whether the LSVCCs have "crowded out" other forms of venture capital firms and have decreased the overall supply of venture capital from what might otherwise have obtained. Cumming and MacIntosh (2006) maintain that LSVCCassociated tax benefits partially compensate investors thereby reducing LSVCCs' required rate of return compared to other types of funds. This, they maintain, allows an LSVCC to outbid a competitor fund with taxable investors, lowering aggregate returns and thus discouraging the establishment of non-LSVCC funds. If institutional investors are risk averse and commit capital prior to knowing the increase in LSVCC fundraising each year, they over estimate the extent of LSVCC fund raising (and consequent crowding out), and reduce their commitments to private venture capital funds. 
Cumming and MacIntosh (2006) present empirical observations consistent with this argument. First, they report that between 1992 and 2001, the share of capital under management controlled by LSVCCs increased dramatically (from 24.2 percent in 1992 to 50.7 in 1996 , and then 41.6 in 2001), while the share of private independent funds, as well as other types of funds, dropped (from 45.5 percent in 1992 to 20.0 in 1998 , and then 25.3 in 2001 for private funds). Second, by estimating the supply and demand equations for venture capital, Cumming and MacIntosh conclude that LSVCCs have crowded out other forms of venture capital funds, resulting in no overall increase in the pool of venture capital in Canada and that the presence of federal LSVCCs has resulted in more than 400 fewer venture capital investments per year (Canada wide), representing nearly one billion Canadian dollars in value, almost all of which represents lost start-up and expansion financing.

If the LSVCCs are an organizational form that is capable of generating returns superior to other fund types, crowding out would not necessarily be a bad thing. However, there is a strong consensus among researchers that performance of LSVCCs is particularly poor (Smith, 1997; Vaillancourt, 1997; Brander et al., 2002; Cumming, 2006; Cumming and MacIntosh, 2006; Brander, Egan, and Hellman 2008). Cumming and MacIntosh (2006) provide a litany of reasons as to why poor performance is the norm. Reasons include:

- LSVCCs are required to be formed as corporations. The use of the corporate form sacrifices the discipline that the limited life span of a partnership imposes on management and diminishes contractual flexibility. Many covenants suitably 
designed to mitigate opportunistic behaviour in limited partnership venture capital funds are absent in LSVCCs. Those include: (1) restrictions on the use of debt; (2) restrictions on co-investment by the organization's earlier and later funds; (3) restrictions on co-investment, fundraising, and other actions by fund managers. In limited partnerships, the use of those covenants varies depending on the characteristics of fund manages (i.e., the intensity of potential agency problems) and the supply-demand conditions in the venture capital industry (Gompers and Lerner, 1996). In LSVCCs, covenants are inflexible across fund managers and invariant over time (subject to statutory change). ${ }^{70}$

- Ownership and control are separated. As the ownership of LSVCCs is highly atomized, few shareholders have the incentives to monitor and discipline fund managers. The sponsoring union controls the fund despite the fact that its economic interest is limited to collecting an annual fee for renting its name to the fund. Cumming and MacIntosh report that many unions in fact have contractually delegated their power to appoint directors to the management company that is contractually engaged to manage the fund. Moreover, many LSVCCs contract with external parties for the supply of vital functions such as investment management, creating additional slack in the investor-manager relationship.

\footnotetext{
${ }^{70}$ Another aspect of LSVCCs is that they are expensive to operate. They require expensive venture capital investment managers and, unlike other types of venture capital funds, a substantial infrastructure to manage the accounts and relationships with the many individuals investors to the fund. Duruflé (2006) reports that LSVCCs have risk averse compensation schemes and missions that lead them to 'spray' more than concentrate on most promising firms.
} 
- LSVCC funds operate under a number of statutory constraints that do not apply to private funds. Those include:

- Investee firms, in general, must be situated in the same jurisdiction as the LSVCC fund and entrepreneurial firms eligible for LSVCC investment are restricted in terms of the nature of business such as size and industry (see Vaillancourt, 1997, Table 2). ${ }^{71}$

- The typical LSVCC lock-in is eight years, shorter than that of private funds (usually ten years). ${ }^{72}$

- The number of allowable funds is restricted in certain jurisdictions.

o LSVCC funds must invest 60 to 80 percent of contributed capital in private entrepreneurial firms within certain deadlines (usually one or three years), and place any balance that remains uninvested in specified low risk investments, such as risk-free short-term government and corporate debt obligations.

\footnotetext{
71 "Eligible investments" excludes shares of a foreign corporation. This means that, when the venture capitalist sells its ownership of an investee firm to a foreign company (through an acquisition or a secondary sale), it must receive cash as consideration (not shares of the acquiring company). Cumming and MacIntosh (2002) argue that the venture capitalist's exit price may be reduced by this constraint, which forces the venture capitalist to accept consideration in currency that is less than the nominal amount of corporate shares that it might otherwise have received.

72 That is: investors can withdraw after eight years. The likelihood of early withdrawal of contributed funds (before the elapse of the lock-in period) is substantially lowered by the fact that such withdrawal results in all tax credits repayable, plus, fund penalties (typically six percent).
} 
- The size and nature of investment in any given entrepreneurial firm is constrained.

Finally, Cumming and MacIntosh (2006) argue that there is a tendency of the LSVCCs to invest a non-trivial portion of their capital in relatively low risk instruments such as treasury bills and short-term corporate debt obligations, and in some cases to maintain a significant part of their invested portfolios in publicly traded securities, rather than private entrepreneurial companies. Moreover, LSVCCs show a preference for more mature later stage investments (Cumming and MacIntosh, 2002, 2001a). They attribute these tendencies to: (1) lack of skill of LSVCC managers, i.e., their inability to identify promising investments; and, (2) LSVCCs' shorter investor lock-in period, which creates a need to maintain a greater percentage of portfolios in liquid form compared to private funds. The deadline for investments also abridges the time during which due diligence is undertaken; this may lead to poor investment selections and prompt the fund to limit its purview to investments in larger, older, and less risky firms. Further, lower competencies of LSVCC managers imply that they are less likely to act effectively at any of the three stages at which venture capitalists' expertise is applied: choosing investments, providing value-added services, and exiting investments (Cumming and McIntosh (2002).

The inefficient statutory governance structure implies higher agency costs (Cumming and MacIntosh, 2006). The combination of statutory constraints, the inefficient statutory governance structure, and unskilled managers associated with LSVCCs has caused many to question this initiative. Cumming and MacIntosh (2006) estimate that the tax 
expenditures made on the LSVCC programs totaled approximately $\$ 3.3$ billion CDN between 1992 and 2002.

All the studies reviewed above have expressed negative views regarding LSVCCs. On the other hand, there is a study that recognizes some LSVCCs' contributions to Canadian social and economic welfare. Hebb and Mackenzie (2001) divide LSVCCs into two groups: rent-a-union funds and non-rent-a-union funds, arguing that the latter has made significant contributions to the Canadian society and economy.

Rent-a-union funds are LSVCC funds in which unions and associations act as sponsors with only nominal involvement in the fund activities. In fact, rent-a-union LSVCCs characterized by Hebb and Mackenzie (2001) are those described by Cumming and MacIntosh (2001a, 2002, 2006) as LSVCC funds in general. According to Hebb and Mackenzie (2001), rent-a-union funds are located mainly in Ontario and they do not usually have explicit objectives of creating and saving jobs or promoting worker environment. ${ }^{73}$

Non-rent-a-union funds are LSVCC funds in which the sponsored union has control, rather than nominal sponsorship. For these funds, federations of labour (not individual unions) are the sponsors, and are actively involved in the funds' operations. Fonds de

\footnotetext{
${ }^{73}$ Unlike other provinces, Ontario has no restriction on the number of funds within its jurisdiction that can be sponsored by trade unions or associations. This has created a larger number of LSVCCs in Ontario than in other provinces.
} 
solidarité (FTQ) in Quebec is representative of non-rent-a-union LSVCCs. ${ }^{74}$ Other characteristics of non-rent-a-union LSVCCs, according to Hebb and Mackenzie (2001), include:

- The initiative for their creation came from a defined labor body, which serves as its sponsor and promoter.

- They emphasize investments in small- and medium-sized companies, many of which are engaged in traditional manufacturing and labor intensive businesses.

- Non-rent-a-union funds usually have economic and social goals including job retention, job creation, and regional economic development. ${ }^{75}$

Hebb and Mackenzie (2001) argue that non-rent-a-union LSVCCs have worked effectively to attain their goals, as they have improved employment, productivity, worker education, and labor-management relations.

A comparison of Hebb and Mackenzie (2001) with other studies that express negative views about LSVCCs, suggests two things. First, typical LSVCC funds described by most studies are what Hebb and Mackenzie (2001) characterize as rent-a-union LSVCCs. This leads to a hypothesis that the negative impacts of LSVCC funds detected by other studies might be mainly driven by the subset of LSVCC funds that are rent-a-union

\footnotetext{
${ }^{74}$ Non-rent-a-union LSVCCs include Fonds de solidarité (FTQ) in Quebec, Working Opportunity Fund in British Columbia, Crocus Investment Fund in Manitoba, Working Investment Fund in New Brunswick, and First Ontario Fund in Ontario, which have collectively have formed a coalition called the LSIF Alliance.

${ }^{75}$ Moreover, investors in Fonds de solidarité (FTQ) and FundAction (another non-rent-a-union LSVCC in Quebec) are allowed no withdrawal until retirement (early withdrawals incur tax penalties), while most other provinces allow for withdrawal from the fund without penalty after eight years.
} 
LSVCCs. A future study could examine this possibility; it is an important issue to investigate as the presence of LSVCC funds in the Canadian venture capital market is significant.

Second, LSVCC funds, non-rent-a-union LSVCCs in particular, are significantly different from venture capital funds in general. More specifically, the objectives of venture capital funds (profit maximization) and those of non-rent-a-union LSVCCs (such as job retention and creation) are so distinct that comparisons of fund performance based on rates of returns or successful exit rates are probably misleading. ${ }^{76}$

In short, the impact of LSVCC funds in the Canadian society, economy, and venture capital market is still inconclusive and thus there remain issues to investigate. The full evaluation of the LSVCC programs requires examination from various perspectives, such as costs (including tax expenditure), benefits other than financial profits (e.g., job creation), impacts on fund contributors, potential investee firms, and other players in the venture capital community. ${ }^{77}$

\footnotetext{
${ }^{76}$ Yet Hebb and Mackenzie (2001) claims that LSVCCs that deliver collateral benefits (non-rent-a-union LSVCCs) have greater returns on average than those within the same asset class that do not deliver such benefits.

${ }^{77} \mathrm{Hebb}$ and Mackenzie (2001) quote studies that performed cost-benefit analyses on non-rent-a-union LSVCC funds. These studies find positive impacts of non-rent-a-union LSVCCs (the cost incurred by the governments was repaid quickly, cost for each job a non-rent-a-union LSVCC created was far less than the cost for a job creation by most venture capital funds, etc.). However, some of those studies were conducted by a non-rent-a-union LSVCC or its affiliate, and/or lack a thorough comparison between non-rent-a-union LSVCCs and other types of venture capital funds.
} 


\section{1-2-6. Fund Managers' Skill}

As discussed in II-1-2-1, the Canadian venture capital market is relatively young and small compared to the American market so Canadian general partners tend to have shorter track records and less experience and industry knowledge than their American counterparts. According to Duruflé (2006) many Canadian venture capitalists have not gone through many cycles of the venture capital fundraising-investment process. Duruflé reports that: (1) Canadian venture capitalists tend to be less demanding than American counterparts; (2) Canadian venture capitalists are slower to enter new sectors (in 1996, when 30 percent of American venture capital firms were investing in Internet-related companies, none were doing so in Canada); and, (3) there are differences in mindsets between American and Canadian venture capitalists. According to Duruflé Canadian venture capitalists tend to: (a) focus on the CEO; (b) deal with companies as if they were public; (c) view CEO/management change as traumatic; (d) think that the board of directors is a watchdog; and, (e) be Canada-centric. All are in contrast to American venture capitalists who tend to: (a) focus on the entire senior team; (b) treat the companies as if they owned/ran them; (c) view $\mathrm{CEO} /$ management change as expected; (d) think that the board has to add value; and, (e) are Global centric. 


\section{1-2-7. Entrepreneurial Base}

According to the Global Entrepreneurship Monitor (GEM, 2008), Canada has a relatively strong entrepreneurial base and a high rate of entrepreneurship compared to other developed countries. Bosma, Acs, Autio, Coduras, and Levie (2009) report that the United States, New Zealand, Iceland, and Canada have the highest levels of high-growth expectation entrepreneurial activity among all innovation-driven economies. ${ }^{78}$

However, Industry Canada (2004) reports that Canadian venture capitalists perceive few entrepreneurial firms as being ready due to a lack of management skills or unwillingness to share ownership. Duruflé (2006) also argues that Canadian entrepreneurs (and board members) are less skilled than their American counterparts and that Canadian venture capitalists invest in companies with a B-rank management team relatively more frequently. ${ }^{79}$ This is consistent with either or both of the views that Canadian venture capitalists are less demanding than their American counterparts and that there are some talent gaps in Canadian companies in terms of senior management. Duruflé (2006) and

\footnotetext{
${ }^{78}$ The "high-growth expectation early-stage entrepreneurial activity (HEA)" score is measured by the percentage of age 18 to 64 population accounted for by nascent entrepreneurs and owner-manager of a new business who expect to employ at least 20 employees five years from now.

"Innovation driven economies" include: Australia, Belgium, Canada, Denmark, Finland, France, Germany, Greece, Hong Kong, Iceland, Ireland, Italy, Japan, Netherlands, New Zealand, Norway, Singapore, Slovenia, Spain, Sweden, Switzerland, the United Kingdom, and the United States.

${ }^{79}$ Duruflé does not provide definitions of A- and B-rank players.
} 
Industry Canada (2004) also point out the lack of serial entrepreneurs in the Canadian industry (most are first time entrepreneurs). ${ }^{80}$

\section{1-2-8. Rates of Return}

In contrast with the United States, where performance data have been available since the early 1990s, no such data were available in Canada until 2003 (Industry Canada, 2004) when the CVCA started publishing performance data semi-annually. The data, however, show only aggregated returns for early, balanced, and later stage venture capital, mezzanine and buyout funds. ${ }^{81}$

For the United States the average ten-year horizon annualized rate of return over the past 37 years (1969 to 2005) is 27.6 percent, for the European Union 6.5 percent, and for Canada -3.1 percent (-1.4 percent for LSVCC funds) (Duruflé, 2006). For this period annual returns on the S\&P 500 and TSX were 8.2 and 8.1 percent, respectively. ${ }^{82}$ For the 1995 to 2005 sub-period, the average return is still higher for the United States (16.6

${ }^{80}$ Duruflé also argues that Canadian entrepreneurs: (1) are more risk averse than their US counterparts; and, (2) do not have the same operational expertise and access to information to mitigate risk. However, Duruflé does not provide the rationale behind on his argument.

${ }^{81}$ Cumming and MacIntosh $(200 \mathrm{lb})$, based on survey data comprising exits from 112 portfolio companies from 13 venture capital firms in the United States and 134 portfolio companies from 22 venture capital firms in Canada, find that the amount of venture capital investment, exit values, and real returns (both gross and annual), and variance in real return are greater in the United States than in Canada.

${ }^{82}$ However, the comparison is biased in favour of the United States (and Europe to a lesser extent) because funds formed before 1995 represent 46 percent of the sample in the United States, 32 percent in Europe, but only eight percent in Canada. Hence, Canada is under-weighted pre-1995 when returns were better. Duruflé estimates that this explains approximately 11 percent of the 31 percent difference between Canada and the United States, and seven percent of the ten percent difference between Canada and Europe. 
percent) than for Canada ( -3 percent), mainly due to the performance of best American funds (those in the first quartile) (Duruflé, 2006). However, there are some positive indications:

- Median returns for overall sample and returns for funds in the lowest quartile are very similar between the United States and Canada (the median is -2.3 percent for the United States and -2.4 percent for Canada, the average for the lowest quartile is -14.0 percent for the United States and -13.9 percent for Canada);

- As of the end of 2006 , the average ten-year horizon return was 1.8 percent (increased from -3 percent, the 1995 to2005 period average);

- The average return of the Canadian first quartile funds (based on performance) is 19.2 percent, well above that of the TSX and S\&P. ${ }^{83}$

- Starting in 1999, Canadian returns are similar to or, in some cases, better than, American returns (before then, Canada's returns are always lower than those in the United States and Europe).

Duruflé (2006) suggests several possible factors negatively affect Canadian returns, besides the timing issue, including: (1) the industry is young; (2) the money is not concentrated with the best managers in Canada (in the United States, the top performing funds were the largest funds, implying that the money is directed to performing

\footnotetext{
${ }^{83}$ The average return of the American and European Union first quartile are 76.6 and 38.1 percent, respectively.
} 
managers, while in Canada it is the worst performing quartile among Canadian private independent funds $){ }^{84}$ (3) the size of each financing round is small, limiting the growth of portfolio companies; (4) capital allocation by stage (i.e., the early stage focus) appears inefficient, as the number of early stage investments, later stage investments, and exits are all smaller for Canada than in the United States, and the discrepancies become larger when moving towards exits (i.e., the ratio of Canada to the United States is 0.37 for the number of early stage investments, 0.16 for later stage, and 0.11 for exits).

Gompers and Lerner (1999a) and Kaplan and Schoar (2005) find that fund performance has significantly positive effects for the size of the fund and on the probability of raising a new fund (see II-2-5-2 and II-3-2-8). Industry Canada (2004), therefore, argues that it is crucial for the Canadian venture capital industry not only to provide solid and credible performance and other industry information but also to demonstrate its ability to generate appealing returns (compared to other investment options such as the public market), in order to attract more capital especially from institutional and foreign sources.

\section{1-3 Conclusion -Does Small Size Cause Capital Constraint Problems?}

The key characteristics of the Canadian venture capital industry can be summarized in the following manner:

\footnotetext{
${ }^{84}$ Cumming and MacIntosh (2006) argue that the fact that LSVCCs have attracted far more capital than their major competitor (private funds) while exhibiting serious underperformance suggests that venture capital has been inefficiently allocated in the Canadian market.
} 
- Small and young as compared to the American market.

- Comprised of a large number of small funds and small number of large funds and the majority of large funds are government-affiliated. ${ }^{85}$

- The average deal size is about the half that of in the United States

- High-technology sector (e.g., information technology, biopharmaceutical, and other life science) focus.

- Early stage focus.

- Follow-on investment focus.

- Concentrated in Ontario, Quebec, and British Columbia.

- Reliance on foreign venture capital funds' investments, especially at later stages.

- A relatively high level of the government-affiliated LSVCC funds' activity and low level of private independent funds' activity.

- Lower level of institutional investors' involvement.

- Lack of experience and industry knowledge of fund managers (as compared to their American counterparts).

\footnotetext{
${ }^{85}$ Duruflé (2006) argues that Canadian private independent funds are too small and others are less equipped
} to take the lead. 
- Few venture capital-ready entrepreneurial firms (many lack management skills and are unwilling to share ownership).

- Lower rates of return.

It appears that many of those characteristics are inter-related. Small fund sizes limit the capacity of venture capitalists to support and fund their investee firms on an ongoing basis, as manifested in relatively small average deal sizes. Small sizes also create the necessity to rely on large foreign venture capital funds when the investee firms grow and thus need larger amounts of financing (as well as for investments in firms requiring large investments from the early phase of their development, such as life sciences companies). In addition, small sizes lead venture capitalists to focus on early stage and follow-on investments.

Institutional investors' reluctance to participate in venture capital is possibly one of the important issues related to relatively small size of this private independent segment of the Canadian sector. The presence of LSVCCs may be one factor that prompts institutional investors to shy away from the venture capital market (Cumming and MacIntosh, 2006). Moreover, a lack of talented entrepreneurs implies that there may be fewer good investment opportunities and fewer potential venture capital fund managers, both leading to lower rates of return for the industry. Lower rates of return and lack of experience and industry knowledge of venture capitalists can also make it difficult to increase inflows of capital into the industry, which, in turn, results in small fund size. 
Those relationships have been suggested by some studies (e.g., Duruflé, 2006); however, they have not been fully empirically investigated. This dissertation, therefore, addresses this gap. It empirically examines whether being small, in fact, limits Canadian venture capitalists' capacity to support their portfolio companies and leads to a reliance on large foreign funds, and considers possible consequences of such limitation and reliance. The empirical examination of those issues will be done through an examination of Canadian venture capitalists' syndication and exit behaviours. The following sections, therefore, review the literature on those two crucial aspects in the venture capital investment process. 


\section{Syndication Practice in Venture Capital}

This section reviews literature on venture capital syndication, focusing on the motivations behind it. Among the hypotheses as to why venture capitalists syndicate investments, two competing theories are frequently discussed. One considers syndication as a device that allows venture capitalists to achieve diversification for their portfolios (the risk sharing hypothesis). The other regards syndication as a means to combine the differing expertise and knowledge among several venture capitalists (the resource-based view).

To structure the review of these literatures, the first subsection (2-1) provides key definitions. The two following subsections review in turn the two prevailing theories (2-2) and then the existing empirical evidence (2-3). Subsection 2-4 discusses difficulties associated with empirical tests of motives of syndication. Subsection 2-5 considers syndication as a more complex decision-making and formation process, one that may be influenced by multiple factors and one in which both the risk sharing and the resourcebased motives may both pertain. This section concludes (2-6) with a review of research findings consistent with the idea that small fund sizes affect venture capitalists' syndication behaviors via capital constraint problems. 


\section{2-1. Definitions}

Venture capitalists usually make investments alongside other investors. Syndicates are a frequent form of inter-firm alliance in which two or more venture capital firms co-invest in a firm and share a joint pay-off (Wright and Lockett, 2003). The term "syndication" usually means that two or more venture capitalists share a particular round of financing, but it is sometimes used more broadly to refer to situations where different venture capitalists invest in a given project at different times (Brander, Amit, and Antweiler, 2002). The Canadian Venture Capital Association (CVCA) uses the narrower definition, i.e., it defines syndication as two or more investors being in a given transaction, and this dissertation follows the CVCA.

Syndication is an important phenomenon. Manigart et al. (2004) report that more than 60 percent of venture capital investments in the United States in 2000 were syndicated, as were almost 30 percent in Europe and 13 percent in the United Kingdom. Hochberg, Ljungqvist, and $\mathrm{Lu}$ (2007) report that approximately 50 percent of venture capital investments involved syndicated funding in the United States. In Canada, Brander, Amit, and Antweiler (2002) report that syndication is increasingly common, with about 30 percent of the 200 (new) investments made in 1991 syndicated and 60 percent of the 1200 investments made in 1997, results consistent with those of Cumming (2005c). Brander, Amit, and Antweiler further note that syndication occurs soon after initial investment. 
Typically, syndication proceeds with one venture capital firm originating a deal and then looking to bring in other venture capital firms (Gompers and Lerner, 1999b). Within the syndicate, one investor usually takes the role of lead venture capitalist. In general, lead investors are more likely to have larger equity stakes, receive information about the investee firm (in particular in relation to order books, debt repayment schedules, and capital expenditure plans), interact more frequently with investee firms (through both formal board meetings and informal contact), and be represented on the board and hands-on in monitoring (Wright and Lockett, 2003). They require more control rights than non-leads (Cumming, 2002), and devote much more time than do non-lead investors (Gorman and Sahlman, 1989).

\section{2-2. Theoretical Rationales for Syndication: Risk-Sharing versus Resource-Based}

\section{Motives}

There is a large volume of literature that considers motives behind the formation of venture capital syndicates. Among a number of hypotheses, two rationales are discussed and empirically investigated particularly frequently. One argues that risk sharing is the major motive for syndication, emphasising the importance of diversification in venture capital investing considering the high risk and the low liquidity of such investments. The other views syndication as a mechanism for managing portfolio companies more effectively, focussing on the non-financial contributions made, and asymmetric 
information problems faced, by venture capitalists. This subsection looks at those two, sometimes considered competing, ideas.

\section{2-2-1. The Risk-Sharing Hypothesis}

The risk sharing perspective contends that syndication is a means by which portfolio diversification can be enhanced, thereby reducing risk without reducing return (Gompers and Lerner, 1999b; Lockett and Wright, 1999, 2001; Manigart et al., 2004, among others) ${ }^{86}$ The illiquidity of venture capital investments hinders easy portfolio adjustment, making risk diversification at the time of the portfolio construction crucial (Lockett and Wright, 1999), which is, however, difficult due to asymmetric information problems. Given the size of a venture capital fund, syndication allows each venture capital investor to invest in more firms, thereby reducing the exposure to any single investment.

Diversification normally requires making a large number of investments (the smaller the fund size the smaller the size of each investment); however, several factors limit the minimum size of a given investment. These include scale problems (Huntsman and Hoban, 1980), transaction costs (Lockett and Wright, 2001), costs of ongoing

\footnotetext{
${ }^{86}$ The importance of diversification in venture capital portfolios is substantiated by Huntsman and Hoban (1980). Their simulation analysis finds that: (1) the rate of return on venture capital portfolios is highly sensitive to the number of very successful investments it contains; and, (2) a significant number of portfolios containing ten randomly-selected investments produced a rate of return that was less than zero. Huntsman and Hoban conclude that an attractive rate of return can be generated over time by welldiversified portfolios, but adequate diversification requires greater minimal capital levels than may be the case for portfolios containing securities of more mature enterprises with readily marketable securities.
} 
management and monitoring (Huntsman and Hoban, 1980), the need for a lead investor to have control (Lockett and Wright, 2001), the need for agreement or consensus regarding terms and conditions (Lockett and Wright, 2001). Moreover, excessively complicated finance arrangements reduce negotiation room with potential new syndicate partners and may dissuade additional investors (Cumming, 2002).

Risk diversification through syndication appears to be particularly vital for venture capitalists that manage a relatively small fund. When an entrepreneurial firm requires a large capital infusion in comparison to the size of the venture capital fund, syndication may be the only way for the fund to invest in the firm while maintaining a reasonable level of diversification of its portfolio (Lockett and Wright, 1999; Manigart et al., 2004). Larger venture capital firms have fewer incentives to syndicate as they can more easily diversify their own portfolios (Bruining, Verwaal, Lockett, Wight, and Manigart, 2006).

\section{2-2-2. The Resource-Based View}

The resource-based rationale views syndication as a response to the need to share or access information necessary for the venture capital investment process (Lockett and Wright, 1999, 2001; Manigart et al., 2004, among others). The benefit of involving coinvestors is derived from heterogeneous skills, networks, and information that different venture capitalists have, which can be shared among them and each of which can be contributed to the management of investee firms. There are three phases in the venture 
capital process, in which sharing different expertise, contacts, and knowledge benefits venture capitalists.

First, syndication improves access to deal flow and greater access to deal flow allows the venture capitalist to select from a wider range of investment opportunities. Venture capitalists invite their colleagues to invest in their deals in expectation of reciprocation and being invited to join other syndicates in the future (Lerner, 1994a; Lockett and Wright, 1999, 2001; Manigart et al., 2004, among others). Lockett and Wright (1999, 2001) argue that access to deal flow becomes increasingly important in times of intensified competition for deals and greater availability of money to invest.

Second, syndication arguably improves deal selection. Lerner (1994a) was the first to suggest this deal-selection-related rationale for syndication, which is referred to as the "second opinion" hypothesis. When the quality of an enterprise is assessed by different venture capitalists combining their heterogeneous skills and information, the evaluation is likely to be more accurate than when it is assessed by a single investor (Sorenson and Stuart, 1999; Lockett and Wright, 1999, 2001; Brander, Amit, and Antweiler, 2002; Manigart et al., 2004; Hopp and Rieder, 2006; among others). ${ }^{87,88}$

\footnotetext{
${ }^{87}$ However, Casamatta and Haritchabalet (2003) argue that disclosing the presence of the investment opportunity to a second investor (in seeking for the second opinion) is harmful since she or he might become a competitor later (the second investor could compete with the initial venture capitalist to obtain exclusive financing of the project). Their model predicts that experienced venture capitalists are more reluctant to syndicate, as they can evaluate the quality of the potential investee firm more precisely and accurately.

${ }^{88}$ Admati and Pfleiderer (1994) provide a rationale for syndication at later stages of financing, considering a situation where venture capitalists make optimal decisions as to whether the project is continued or abandoned. They show that the venture capitalist makes optimal continuation decisions if and only if she or
} 
Finally, syndication creates complementarities of venture capitalists' skills, knowledge, information, contacts, etc., that can be employed to better monitor, manage, and advise the funded firms (Lockett and Wright, 1999, 2001; Brander, Amit, and Antweiler, 2002; Manigart et al., 2004; Hopp, 2006; Bruining, Verwaal, Lockett, Wright, and Manigart, 2006, among others). ${ }^{89}$

Access to expertise may be particularly important for:

- Early stage investments. Early stage deals have greater need of venture capitalists' assistance and monitoring (Lockett and Wright, 1999, 2001; Hopp and Rieder, 2006) and early stage investors attach more importance in value-adding services (Elango, Fried, Hisrich, and Polonchek, 1995; Sapienza, Manigart, and Vermeir, 1996; Cumming and MacIntosh, 2001b). Lockett and Wright (1999) speculate that the resource-based motive of syndication is more important for venture capital firms with smaller minimum investment preferences, because they are

he holds a fixed-fraction contract, where she or he always received a fixed fraction of the project's payoff and finance that same fraction of future investments. If the fraction of new investment that the venture capitalist puts up is higher than the fraction of the final payoffs she or he is promised, in some situations the venture capitalist would abandon the project that should be continued. If the venture capitalist obtains a higher fraction of the payoff than the fraction of the investment she or he puts up, there would be projects that she or he would choose to continue, even if it would be optimal to abandon them. If the entrepreneur retains a stake in the project (if the venture capitalist is not the sole investor), this contract requires that outside investors are involved in later financing stage. Lerner (1994a) observes that the ownership stake of venture capitalists frequently stays constant in later rounds, confirming the prediction of Admati and Pfleiderer.

${ }^{89}$ Brander, Amit, and Antweiler (2002) hypothesize another rationale for syndication, related to the resource-based motive (the collusion hypothesis): by banding together rather than competing, venture capitalists might improve their bargaining power with entrepreneurs. However, studies suggest that conflict of interest, moral hazard, and free riding behaviors among syndicate members are problems in syndicating investments (see II-2-4-4). 
more likely to invest in risky earlier stage firms, for which venture capitalists need more informational resources to monitor and add value.

- Geographically dispersed investments. Distant deals require intense monitoring in order to mitigate information asymmetries (Bruining, Verwaal, Lockett, Wright, and Manigart, 2006; Hopp and Rieder, 2006). ${ }^{90}$ Syndication makes geographically dispersed investments easier as the distant venture capitalist's unfamiliarity with the market is made up for by the skills and expertise of local venture capitalists in the syndicate (Sorenson and Stuart, 2001). ${ }^{91}$

- Investments outside of the venture capitalist's specialization (Bruining, Verwaal, Lockett, Wright, and Manigart, 2006). Tykvová (2005) points out that the knowledge transfer between partners is an important economic benefit from syndication. Likewise, Hopp and Rieder (2006) argue that venture capitalists get access to deals in unfamiliar industries by complementing their existing resources with partners' capabilities, which enables the venture capitalist to make investments in new industries worthwhile.

\footnotetext{
${ }^{90}$ Lerner (1995) and Cumming (2006) provide evidence consistent with the view that the oversight of an investee firm is more costly when it is located at a distance. The venture capitalist is less likely to be a board member when he or she is further away from the investee firm (Lerner, 1995). Canadian funds investing more frequently in out-of-province firms tend to have smaller number of companies in their portfolios (consistent with the view that, because distant investments requires extra effort to monitor, they lower the number of entrepreneurial firms venture capitalists effectively manage (Cumming, 2006).

${ }^{91}$ This also suggests, as Sorenson and Stuart (2001) argue, that syndication allows venture capitalists to build up their social networks beyond geographic boundaries, thereby they expand the spatial radius from which they obtain investment opportunities (i.e., syndication facilitates access to deal flow).
} 
- Younger venture capital firms. Syndication provides access to the superior expertise of other venture capital firms, thereby improving the quality of selection, management, and monitoring of investments (Bruining, Verwaal, Lockett, Wright, and Manigart, 2006). Larger venture capital firms are less likely to need external expertise and therefore have a less incentive to syndicate their investments. Seppä and Jääskeläinen (2002) argue that economic actors are willing to form exchange relationships with high-status firms because: (1) a firm's reputation and its ability to mobilize resources are likely to improve when it cooperates with prestigious exchange partners; (2) a firm associated with high-status partners is likely to be conceived to be of higher status than that without such an association; and thus (3) a firm's performance is affected by the status levels of its close associates.

\section{2-3. Risk-Sharing versus Resource-Based Motives - Empirical Evidence}

Both the risk sharing and the resource-based rationales have been empirically tested extensively. Many studies view those as two competing views and thus test whether risk diversification or acquiring (non-financial) resources is the major driver for syndication. 


\section{2-3-1. Empirical Evidence Supporting the Risk-Sharing Hypothesis}

Lockett and Wright (1999, 2001), Manigart et al. (2004), and Bruining, Verwaal, Lockett, Wright and Manigart (2006) find evidence supporting the view that diversifying the risk of the portfolio is the dominant motive for syndication. It is noteworthy that these studies all use data collected from surveys of European venture capitalists. In all studies, risksharing-related motives are scored by fund managers as more important, on average, than resource-based motives. For example, when venture capitalists syndicate in a deal, "the large size of the deal in proportion to the size of funds available" and "the requirement for additional rounds of financing" are the two most important factors. Similarly, risksharing-related factors are more important on average than resource-based-factors when venture capitalists decide not to syndicate out a deal, with the most importance given to "the small size of the deal" (Lockett and Wright, 2001).

\section{2-3-2. Empirical Evidence Supporting the Resource-Based View}

There are two types of studies that provide evidence supporting the resource-based motive. One category empirically shows the importance of acquiring (non-financial) resources as a motive for syndication, in comparison with the importance of the risksharing motive. The other focuses on a particular purpose of syndication within the category of resource-based motives, such as access to deal flow, deal selection and management of investee firms. 
Importance of the Resource-based Motive in Comparison with the Risk-Sharing Motive

Bygrave (1987, 1988) and Norton and Tenenbaum (1993) provide evidence consistent with the view that accessing other venture capitalists' networks, expertise, and knowledge is the primary reason to syndicate. Note that those studies are carried out in the United States. Bygrave's (1987) findings include:

- The average number of syndicate members per portfolio company is significantly higher for venture capital firms that invest mainly in high innovative technology companies than those that invest mainly in low innovative companies - even though the average total investment in high innovative technology firms (\$1.6 million US) is significantly less than in low innovative firms (\$2.4 million US).

- Similarly, the average amount invested in early stage firms (\$1.7 million US) is smaller than that in late stage firms (\$2.0 million US), but the average number of syndicate members is significantly greater in investments in early stage than late stage firms.

- While there is almost no difference in the average amount invested between computer (\$1.4 million US) and consumer companies (\$1.5 million US), the average number of syndicate members is significantly greater in investments in companies in the computer industry than those in the consumer industry. 
Bygrave (1987) concludes that these findings support the notion that syndication is driven much more by the need to share expertise than by the need to spread financial risk. ${ }^{92}$ Moreover, he finds no difference in number of syndicate partners between small (fund managing $\$ 3$ million to $\$ 46$ million US) and large (fund managing $\$ 50$ million to $\$ 230$ million US) venture capital firms. Since the risk diversification motive predicts that small venture capital firms have greater need for syndication, as larger venture capital firms have a greater capacity to spread financial risk internally. Thus, Bygrave argues that this finding also supports the notion that sharing of expertise is more important than spreading of financial risk. ${ }^{93}$

In a following study, Bygrave (1988) finds that the top 21 venture capital firms that invest mainly in high innovative technology companies (HIVCs) are more tightly bound together than the top 21 venture capital firms that invest mainly in low innovative technology companies (LIVCs). ${ }^{94}$ Bygrave argues that this finding is a reflection that HIVCs shoulder more uncertainty and therefore have a greater need to share information with one another. Similarly, De Clercq and Dimov (2004) find that venture capital firms that tend to invest in companies at earlier stages of development are more likely to

\footnotetext{
${ }^{92}$ We argue, however, that those empirical observations could also be consistent with the risk-sharing motive, as making riskier investments may require greater diversification of venture capital portfolios.

${ }_{93}$ However, Bruining, Verwaal, Lockett, Wright, and Manigart (2006) argue that larger venture capital firms may have more management expertise and, therefore, lesser need for syndicating a deal in order to acquire expertise from other venture capital firms. To the extent that Bruining et al's argument holds empirically, this finding of Bygrave is inconsistent with the sharing of expertise motive for syndication.

${ }^{94}$ Of that group, the nine HIVCs located in California are most tightly bound together. The HIVCs cluster in the northeast and California, while the LIVCs are spread more evenly throughout the United States.
} 
syndicate. ${ }^{95}$ They argue that this is consistent with the resource-based rationale for syndication, as sharing knowledge is essential for the venture capital firms when facing higher uncertainty, which is associated with earlier stage investments. Likewise, Norton and Tenenbaum (1993) examine data from a survey of 98 American venture capitalists, providing empirical observations in favor of the resource-based view (information sharing motive). ${ }^{96}$

The following section reviews studies that focus on one of several non-financial benefits of syndication, such as access to deal flow, better deal selection, and better management of investee firms, and investigates how syndicates help venture capitalists in that aspect.

\section{Deal Flow}

Sorenson and Stuart (2001) investigate geographic and industrial boundaries in venture capitalists' investment opportunities, and find empirical evidence consistent with the deal

\footnotetext{
${ }^{95}$ De Clercq and Dimov (2004) also find that venture capital firms that tend to invest in later rounds for their first time use syndication to a higher degree, which they consider evidence supporting the risk-sharing argument (i.e., entrepreneurial firms at later rounds typically require larger amounts of capital and such increased investment requirements often cannot be met by one venture capital firm). However, this result may not be related to the risk-sharing motive. In order for a venture capital firm to invest at the second or later round for the first time, a syndicate (or one venture capital firm's investment) must have already existed, and the positive association between a venture capital firm's propensity to syndicate and the average round number of its first time investments seems a natural consequence of this.

${ }^{96}$ For example, Norton and Tenenbaum find that venture capitalists that are heavily involved in seed round financing diversify their portfolio across fewer numbers of firms and industries. They argue that the risksharing motive predicts that venture capitalists that make early stage investments will be more diversified to compensate for their risky individual investments; on the other hand, the resource-based view implies that such venture capitalists have a narrow focus or industry specialization, in order to gain access to information flows and deal flows in networks through their reputation in their specialization, thereby managing operating and technical risks.
} 
flow motive of syndication. ${ }^{97}$ More specifically, they find that: (1) the likelihood that a venture capitalist invests in an entrepreneurial firm drops sharply as the entrepreneurial firm moves away from the venture capitalist in either geographic or industrial space; ${ }^{98}$ but, (2) a venture capitalist is more likely to invest in a far off entrepreneurial firm when there is a colleague, with whom the venture capitalist has previously co-invested, in the syndicate of the entrepreneurial firm; (3) the closer the syndicate partner (with whom the venture capitalist has previously co-invested) to the entrepreneurial firm, the more likely the venture capitalist is to invest in the geographically distant entrepreneurial firm. ${ }^{99}$ Sorenson and Stuart (2001) argue that information about potential investment opportunities circulates within geographic and industry spaces, but syndication diffuses information across such boundaries and thus expands the spatial radius of exchange. ${ }^{100}$ Syndication allows a venture capitalist to rely on the evaluations of another venture

\footnotetext{
${ }^{97}$ Sorenson and Stuart (2001) argue that because: (1) entrepreneurs at previously funded start-ups and contacts generated from working in an industry represent important sources for the identification of new investment opportunities; and, (2) venture capitalists typically perform due diligence and monitoring more expeditiously and successfully when they have prior investment experience, industry represents another dimension that delimits information flow (see II-2-5-3).

${ }^{98}$ For example, a venture capitalist invests in companies ten miles from his or her office at twice the rate of ones situated 100 miles away, and a venture capitalist that specializes completely in the same industry in which the entrepreneurial firm operates is nearly six times more likely to invest in a target than one that has never before invested in the entrepreneurial firm's industry. Sorenson and Stuart (2001) measure industry distance as the percentage of previous investments that the venture capitalist has made in industries other than the one in which the entrepreneurial firm operates.

${ }^{99}$ Sorenson and Stuart (2001) also find that:

- Geographic (and industrial) distance has less of a negative effect on the probability of investing in a far off entrepreneurial firm for highly central venture capitalists.

- The age and experience of a venture capitalist, two variables that have significantly positive effect on the likelihood that the venture capitalist invest in a geographically far off entrepreneurial firm, becomes insignificant when the specification includes the variable for the venture capitalist's network position. They interpret this finding as a reflection that experience primarily influences the geographic scope investing through the development of one's network via syndication.

100 This also allows venture capitalists to diversify the risk specific to regional or industrial economic cycles.
} 
capitalist, with whom the former has established a trust relationship and who is closer to the entrepreneurial firm in industrial or physical space.

Guler and Guillén (2006a, 2006b) obtain similar results. They analyze American venture capital firms' investment behaviour in foreign countries, and find that the greater the number of entrepreneurial firms invested in a country by the venture capital firm's syndication partners, the more likely the venture capital firm is to make investments in the country. Guler and Guillén (2006b) conclude that, while venture capital firms always prefer countries with lower uncertainty, firms whose syndication partners have already entered the foreign market are more tolerant towards the level of political uncertainty in the country.

Hochberg, Ljungqvist, and $\mathrm{Lu}$ (2007) find evidence suggesting that inviting many venture capitalists into one's syndicates creates many future syndication opportunities: the one-year lagged number of other venture capitalists the venture capitalist invited into its own syndicates is significantly positively associated with the venture capital firm's current tendency to be invited into other venture capitalists' syndicates.

Lerner (1994a) considers one aspect of venture capital deal flow, proposing a rationale for venture capitalists to enter into an existing syndicate at later financing rounds. He argues that venture capitalists may decide to participate to a syndicate at later rounds, shortly before the entrepreneurial firm goes public. They do so in order to increase the number of successful exits in their portfolios (even if the financial returns are low), i.e., 
"window-dress" their performance, for easier future fundraising activities. Early venture investors (those who have already invested in the promising firm) may curry favour with their colleagues by permitting them to invest in later-round financings of promising firms, in the hope that the colleague will in turn offer them opportunities to invest in later rounds of their deals.

Lerner (1994a) argues that if this window dressing hypothesis holds, venture capitalists should offer shares in the best deals to those firms most able to reciprocate (i.e., wellestablished venture capital firms), and thus an empirical implication of this hypothesis is that experienced venture capitalists will invest in the later rounds of deals particularly likely to go public. Lerner observes that, when the firm is performing well (i.e., the firm's valuation has increased over the prior venture round), experienced venture capitalists are more likely to invest in the firm for the first time in later stage, and valuation changes are negative and insignificant in explaining the probability of investments by less established firms.

\section{Selection of Investment}

Lerner (1994a) investigates the deal-selection-related rationale for syndication (the "second opinion" hypothesis) exclusively. He claims that, if venture capitalists were looking for a second opinion, they should be careful in their choice of first-round syndication partners, i.e., they would want to get a second opinion from someone of similar or better ability, certainly not from someone of lesser ability. That is: (1) 
established venture capitalists should disproportionately syndicate first-round investments with other established (rather than inexperienced) venture capital organizations; and (2) seasoned venture capitalists should invest with both experienced and inexperienced venture capitalists in later rounds; (3) experienced venture capitalists should be reluctant to invest in the later rounds of deals begun by their less seasoned counterparts (inexperienced venture investors should be brought into later round financings by experienced organizations, but not vice versa). Lerner finds that: (1) the smallest and youngest quintile of venture capital organizations is disproportionately likely to undertake early round transactions with each other; but, (2) this pattern becomes less pronounced with each subsequent round; (3) the typical later-round syndication involves smaller, or younger, or less industry-experienced venture capitalists investing in a deal begun by larger, or older, or more industry-experienced organizations. ${ }^{101}$ Lerner claims that these results are consistent with the view that syndication is a device through which established venture capitalists obtain information to decide whether to invest in firms.

Hopp (2006) finds in Germany that when a particular round of investment is made by a syndicate, the duration to the next round is longer, and the amount provided is larger, than when it is made by a single venture capital firm. Hopp (2006) interprets this as a reflection that involving partners in the decision-making process before the decision to

\footnotetext{
${ }^{101}$ Lerner uses age, size (committed capital in the year of the investment as a percentage of the total pool of venture capital), and industry-experience (the number of firms in which the organization have previously invested) as proxies for the degree to which the venture capital organization is established.
} 
fund a new investment proposal or an additional round of financing reduces the potential risk of asymmetric information and mitigates agency problems (increases the venture capitalists' confidence in the funded firm, i.e., reduces their incentive to monitor the firm more closely), and thus leads them to provide more financing for a longer period of time on average. Those results are, therefore, consistent with the view that syndication, which involves partners into the decision-making process, improves deal selection (i.e., Lerner's (1994a) second opinion Hypothesis) as well as any decision-making at the time of an additional round of financing. ${ }^{102}$

\section{Management of Investee Firms}

Brander, Amit, and Antweiler (2002) argue that a second opinion is valuable when the quality of the project under assessment is in the intermediate range, i.e., when the project quality is apparently low or high, there is no point in seeking a second opinion. This implies that, if venture capitalists syndicate their investments in seeking a second opinion, the most promising projects are taken up as standalone investments, while projects of more moderate promise are put in the syndication pool. Thus, standalone projects should, on average, yield higher returns than syndicated projects, if better deal selection is the dominant motive for syndication. On the other hand, if access to management expertise is the dominant motive for syndication, syndication allows venture capitalists to add value to investee firms more effectively than standalone investment,

\footnotetext{
${ }^{102}$ Hopp finds that more experienced venture capital firms (measured by capital under management) are more likely to have a higher average number of financing rounds per investee firm.
} 
thus syndicated projects should have higher rates of return than standalone projects. ${ }^{103}$ Brander, Amit, and Antweiler (2002) investigate returns (the annualized arithmetic real rate of return) on Canadian venture capital investments during the period from 1992 to the first quarter of 1998. They find that syndicated investments earn, on average, significantly higher returns than standalone investments, and a larger number of venture capitalists is associated with higher returns. They conclude that the value-added hypothesis seems more relevant than the Second Opinion Hypothesis. ${ }^{104}$

${ }^{103}$ This argument holds when venture capitalists are risk-neutral. However (as Brander, Amit, and Antweiler admit), it is also plausible that venture capitalists are risk averse. In this case, an empirical observation of higher returns for syndicated investments (rather than standalone investments) is consistent not only with the view that access to management expertise hypothesis but also the risk-sharing hypothesis (i.e., venture capitalists might seek syndication over high risk (and high return) investments. In fact, they find that the standard deviation of returns to syndicated investments (100.2) is significantly higher than that of standalone investments (80.3), consistent with the risk-sharing hypothesis (if risk sharing is the major motive for syndication, venture capitalists would seek syndication over more risky investments so as to allow themselves more diversification).

${ }^{104}$ Lockett and Wright $(1999,2001)$ and Manigart et al. (2004) report the relative strength of a particular non-financial motive compared to others. For example:

- Consistent with Brander, Amit, and Antweiler (2002), Lockett and Wright (1999) find that venture capitalists in the United Kingdom rate "the need to access specific skills in order to manage the investment" as significantly more important than "the need to seek the advice of other venture capital firms before investing," suggesting that the ex post management of investments is more important than deal selection as a motivation for syndication.

- Manigart et al. (2004) find that European venture capitalists score access to deal flow as more important than better deal selection and post-investment management as a motive of syndication. However, Lockett and Wright (2001) find that venture capitalists in the United Kingdom rate the deal flow motive as more important than the resource-based motive.

- Lockett and Wright (1999) find that venture capitalists in the United Kingdom rate "not having experience of the industry sector, investment stage or geographical region" as less important than "having experience of the industry sector, investment stage or geographical region" when they make a decision to join a syndicate. This may suggest that venture capitalists do not join syndicates in order to gain experience of industry sectors, investment stages or geographical regions in which they do not have experience. 


\section{2-4. Challenges to Testing Motives for Syndication}

The above literature review has discovered that there are empirical studies supporting both the risk-sharing motive and the resource-based view. A universally concurred view as to whether sharing risk or acquiring additional (non-financial) resource is the dominant rationale for syndicating venture capital investments, has not yet been obtained.

It is worth noting that there is a geographical difference in empirical findings. Studies investigating outside of the United States find the financial (risk-sharing) motive a more important driver for venture capitalists to syndicate (Lockett and Wright, 1999, 2001 (the United Kingdom); Manigart et al., 2004 (six European countries); Bruining, Verwaal, Lockett, Wright, and Manigart, 2006 (six European countries), while those examining the American practice find the resource-based motive dominating over the risk-sharing motive (Bygrave, 1987, 1988; and Norton and Tenenbaum, 1993). This may be a reflection of a difference in venture capital investment practice between the United States and outside interests (Europe). Or, it may be because of the difference in the definition of venture capital between Europe and North America: for example, the United Kingdom studies, Lockett and Wright $(1999,2001)$, include firms that invest in MBO/MBI only into their analysis.

Or, it may result from a methodological issue: European studies use survey data, while American studies use outcome data (performance or investment patterns) and infer investment decisions from the outcomes. Survey data are more likely to be subject to 
self-reporting bias, reflecting venture capitalists' perceptions and intended investment strategies. Outcome data reflect realized strategies, but they generally require inferences about associations between a venture capital firm's (or an investee firm's) characteristics and a particular motive for syndication (e.g., small venture capital firms need to syndicate more often as it is more difficult for them to diversify their portfolios by their own), based on which conclusions are drawn as to the dominant syndication motive (e.g., because small venture capital firms syndicate more often, risk sharing is the dominant motive for syndication). However, it appears problematic to make such associations. For example:

- Both the risk sharing and resource-based hypotheses predict that larger venture capital firms are less likely to syndicate their deals (Bruining, Verwaal, Lockett, Wright, and Manigart, 2006). Larger firms are better able to diversify their investments, ${ }^{105}$ have more management expertise, and more access to deal flow thanks to their central network positions, all of which lower need to syndicate their investments.

- Both the risk sharing and resource-based hypotheses expect that venture capitalists jointly invest in firms exhibiting higher risk (Hopp and Rieder, 2006). The higher the uncertainty over the expected outcome, the more venture

\footnotetext{
${ }^{105}$ Gupta and Sapienza (1992) find that larger venture capital firms prefer greater industry diversity and broader geographic scope. In 1987, Bygrave predicts that "[v]enture capitalists will increasingly specialize according to type of companies in which they invest. Only the largest firms with many venture capitalists will be like "department stores," which invest in all types of companies. The smaller firms, with only a few venture capitalists, will tend to be more like "boutiques" which invest in specific types of companies, or in specific geographical regions around the world (pp. 139-140)."
} 
capitalists are inclined to syndicate the investment. At the same time, the more likely conflicts with the entrepreneur are, the more value can be gained by involving a partner into the ex ante selection or the ex post management of investments. $^{106}$

- It is unclear whether less or more established venture capital funds have stronger risk aversion, i.e., stronger motive to share risk (Lerner, 1994a). A new venture organization may believe that a follow-on fund is difficult to raise unless it performs very well, thus make high-risk high return investments by itself. Alternatively, an established venture organization may believe that its reputation will allow it to raise a later fund even after a disastrous performance, and thus be willing to invest alone in risky but promising projects. Lerner (1994a) argues that we would need to know about the utility function of the venture capitalists, the status of their current funds, and their future fundraising plans, in order to analyze empirically the relationship between risk aversion and syndication.

- It is unclear whether less or more established venture capital funds have stronger needs to acquire non-financial resources of other venture capital firms. Lockett

\footnotetext{
${ }^{106}$ Hopp and Rieder (2006) find that: (1) syndication is more pronounced in investment in younger firms, biotech, pharmaceutical, Internet, software, and medical firms, and firms with lower sales per employee, and are less pronounced in more established and mature industry investments, such as industry products and services, and financial; and, (2) venture capital firms focusing on non-high technology companies syndicate less. However, it is uncertain whether those results are the reflection of venture capitalists' desire to spread risk of more risky investments (consistent with the risk-sharing hypothesis) or their need of a complementary skill set to overcome asymmetric information problems, which are more severely associated with those investments where more specific knowledge is required (consistent with the resourcebased motives).
} 
and Wright (2001) argue that venture capitalists with greater experience and reputation may be less motivated to syndicate because they believe that their expertise will generate superior returns by making in sole investments. Similarly, Casamatta and Haritchabalet (2003) argue that, to the extent that more experienced venture capitalists obtain more precise and accurate evaluation on the quality of the potential investee firm, they are more reluctant to syndicate. On the other hand, experienced venture capitalists may still be motivated to syndicate because they place importance on reducing the variance of their returns and/or gaining access to deal flow (Lockett and Wright, 2001).

- It is unknown, from outcome data, whether a venture capitalist's tendency to syndicate deals is a reflection of their need/desire to syndicate, or an indication of the syndication opportunities available to them. For example, small venture capital firms may have stronger desire to syndicate due to either higher need to spread risks among a larger number of investments or acquire expertise, but may be less welcomed to a syndicate for their lower reputation (Hopp and Rieder, 2006). ${ }^{107}$ In contrast, large venture capital firms may have less need to syndicate,

${ }^{107}$ Bruining, Verwaal, Lockett, Wright, and Manigart (2006) argue that smaller venture capital firms are relatively less welcome in a syndicate as they are more likely to: (1) increase the number of syndicate members involved; (2) change their investment focus if their relatively smaller funds are fully invested; (3) be perceived to have higher risk of opportunism (Nootebroom, 1993); and, (4) presents a greater risk of default because of a lesser spread of risk (Nootebroom, 1993), all of which increase the risk of discontinuity towards syndicate partners. Hochberg, Ljungqvist, and Lu (2007) find observations suggesting that a venture capital firm has to prove its ability to find and produce winners in order to invite other venture capitalists into its syndicates, those are: (1) the one-year lagged number of IPO and M\&A transactions have a positive association with the number of other venture capitalists the venture capitalist has invited into its own syndicates; (2) the one-year lagged number of portfolio companies that received follow-on funding lead-managed by outside venture capitalists (proxies the venture capitalist's ability to 
as they are likely better equipped either with knowledge and expertise or larger portfolios (or both) enabling them to spread risks by themselves. However, such venture capital firms are also more likely to be invited to a syndicate due to their well-established central position within the venture capital community (Lerner, 1994a; Sorenson and Stuart, 2001; Hochberg, Ljungqvist, and Lu, 2007), or they need to syndicate in order to maintain these positions (Manigart et al., 2004). It is possible that size influences syndication behaviour in both ways in practice, cancelling out the size effect on syndication behaviour when statistically analyzed. $^{108}$

The ambiguity in association between venture capitalists' (and investee firms') characteristics and a particular motive of syndication appears to be a major challenge in empirical investigation on the dominant rationale behind syndicating behaviour from outcome data. On the other hand, questionnaire-based studies are subject to self-reporting

persuade outside venture capitalists to lead-manage a follow-on funding round, i.e., his or her ability to prove the investment is successful) is significantly positively associated with its network position.

${ }^{108}$ Bruining, Verwaal, Lockett, Wright, and Manigart (2006) find an inverse U-shaped relationship between venture capital firm size and the degree of syndication: the proportion of syndicated deals increases as the firm size becomes large up to a certain point, and beyond that point the proportion of syndicated deals decreases as firm size increases (using the number of venture capital firm executives as the size measure). This may imply that the effect of smaller firms being less welcome in a syndicate overweighs the effect of their stronger need of syndication, and the effect of larger firms having lower incentive to syndicate overweighs the effect of them being more frequently invited to a syndicate. On the other hand, Hopp and Rieder (2006) find that, in Germany, a U-shaped (rather than an inverse U-shaped) relationship between the propensity to syndicate and experience (as measured by the total amount of capital that have been invested in Germany by the venture capital firm), which suggests that less and more experienced venture capitalists make more use of syndication, while those in the middle do less. They argue that for smaller, less experienced firms, the higher need for syndication outweighs the potential costs of deal coordination, behavioral uncertainty and low reputation, while for larger, experienced venture capital providers the lower incentive to syndicate is outweighed by the potential to benefit of syndication (i.e., the potential deal flow from reciprocating partners, since they are more likely to have a more central network position within the $\mathrm{VC}$ community). 
bias, reflecting venture capitalists' perceptions and intended investment strategies. ${ }^{109}$ Again, this section reveals that American studies find that accessing other venture capitalists' deal flow network, expertise, and information is the dominant motive for syndication, while European studies find risk diversification a major purpose. Further research is necessary to make it clear whether this difference in findings truly reflects the difference in syndication practice between the two continents, or whether it results from a definition of venture capital, or a difference in research methodologies.

\section{2-5. Syndication Decision-Making as a Complex Process}

Studies reviewed so far try to determine the dominant motive for syndication, whether syndication is driven by the risk diversification purpose or acquiring other venture capitalists' (non-financial) resources. However, there are views that venture capitalists' decision to syndicate is not driven by one motivation but through a more complex process involving several factors inter-relating with each other. For example, Hopp and Rieder (2006) argue that financial (risk-diversification) and non-financial resource driven motives may exist simultaneously and both might at the same time have an impact on the observed syndication pattern. Bruining, Verwaal, Lockett, Wright, and Manigart (2006)

\footnotetext{
${ }^{109}$ Brander, Amit, and Antweiler argue that testing the risk-sharing hypothesis requires an investigation of the contribution of a given investment to the venture capitalist's overall portfolio risk, which depends on the investment's covariance structure vis-à-vis other investments in the portfolio. Lerner (1994a) argues that to analyze empirically the relationship between risk aversion and syndication, it is necessary to know the utility functions of the venture capitalists, the status of their current funds, and their future fundraising plans.
} 
suggest that different venture capitalists likely have different strategic positions; this also suggests different venture capitalists use syndication in different ways. Moreover, there are views that the tradeoffs exist between risk diversification and management of investee firms, as well as between diversification and portfolio specialization, and that syndication plays a role of mitigating such tradeoffs. Finally, some studies argue that there are costs associated with syndication, creating a trade-off between costs and benefits within the decision-making process whether to syndicate a deal.

All those arguments suggest that the decision to syndicate may not be driven by a single motivation but involves multiple factors affecting the costs and benefits of syndicating investment. The following reviews those arguments.

\section{2-5-1. Simultaneous Presences of the Risk-Sharing and the Resource-based Motives}

Studies that try to determine which is the dominant motive for syndication, the risksharing motive, or the resource-based one, implicitly assume that those two motivations are mutually exclusive. Hopp and Rieder (2006) argue, however, that both motives might be present at the same time. Their argument seems plausible as risk diversification, access to deal flow, deal selection, and management of investee firm, all are crucial aspects of venture capital investment. 
Hopp and Rieder (2006) find, in Germany, empirical observations consistent with both the risk-sharing hypothesis and resource driven motives. As evidence supporting the risksharing motive, they observe:

- The size of the investee firm (as proxied by the number of employees at the time of the investment) has a significantly positive impact on both the propensity to syndicate and the number of investors per deal. Hopp and Rieder (2006) argue that the number of employees reflects the size of the deal (i.e., the size of the acquirable stake), and thus this finding is in line with the risk-spreading perspective: larger deals require venture capitalists to take a much higher exposure, and venture capital firms make use of syndication in order to reduce size exposure..$^{110}$

As evidence supporting resource-based motive, Hopp and Rieder (2006) observe:

- Experienced venture capital firms (measured by the number of investments that have been undertaken by the firm) are less likely to syndicate, while the size of the firm (measured by the amount of capital under management) does not influence the firm's propensity to syndicate. Hopp and Rieder (2006) interpret those results as an indication that experience reduces the need to rely on partners for complementary skills and knowledge.

\footnotetext{
${ }^{110}$ However, in Hopp and Rieder (2006) other measures of firm size (sales at the time of the investment and sales per employees) have no impact on the syndication behaviour.
} 
- Non-German investors (those with a foreign origin and not operating from a German branch) are significantly more likely to syndicate investments in Germany. Likewise, a higher percentage of investments in Germany are negatively associated with propensity to syndicate. Both are consistent with the view that a certain familiarity is necessary for successful management of venture capital funds, and that syndication as part of an entry strategy can help venture capitalists to overcome the lack of experience in a foreign market.

- Syndication has a positive impact on sales growth for the funded firms. Firms that can benefit from the complementary skill set of syndicate partners are associated with a higher level of sales growth after the funding events.

Moreover, Hopp and Rieder (2006) find that on one hand, venture capitalists that have a greater number of co-investors with whom she or he has undertaken a deal tend to have less concentrated portfolios; on the other hand those who syndicate their deals more frequently tend to have a more concentrated portfolio. These results imply that venture capitalists diversify their portfolios through working with a greater variety of partners outside his or her scope of industries, while they also strengthen focus on their specialized industries through syndication. Hopp and Rieder (2006) conclude that financial and resource driven motives are present at the same time, as both play a significant role simultaneously for the decision to jointly co-invest. 
Manigart et al. (2004) argue that the motive to syndicate may be different between lead and non-lead investors. A lead investor is typically more involved in the investee firm, taking responsibility for close monitoring, value adding, board interaction, relationship building, working towards an exit, etc., and therefore the ultimate performance of the investment. Manigart et al. therefore argue that a lead investor is more likely to syndicate out a deal when she or he has the necessary resources to manage the investee firm successfully (if not, they might risk losing their reputation in the investment community).

On the other hand, joining a syndicate initiated by a respected lead investor may increase the legitimacy of the non-lead investor, i.e., the fact that the venture capitalist is chosen by a respected lead may send a signal of his or her quality and of the value of the resources she or he brings to the syndicate. Moreover, the venture capitalist is able to learn from other syndicate members. This suggests that venture capitalists may join syndicates when they need to access additional (non-financial) resources. Manigart et al. (2004) group venture capitalists in accordance with whether they are active as a lead investor or as a non-lead investor, and find that the active non-lead considers the resource based motives as more important than the active lead (while European venture capitalists in general view the risk-sharing motive more as important than the resource-based motives (see II-2-3-1). They further find that venture capitalists who consider the financial motive important are significantly more likely to act as a lead investor, while those who consider the resource-based motive important are significantly more often to act as non-lead. Findings of Hopp and Rieder (2006) and Manigart et al. (2004) suggest 
the simultaneous presence of the risk-sharing and the resource-based motives, and that syndication motives and behaviours may be different across different types of venture capital firms and on different occasions.

\section{2-5-2. Trade-offs between Diversification and Dilution of Human Capital}

Investing in multiple ventures, as opposed to a single project, allows venture capitalists to diversify their portfolios. However, any addition to a portfolio is costly as it is associated with transaction costs, in particular, the dilution of the quantity and quality of managerial advice to each entrepreneurial venture (Lockett and Wright, 1999, 2001; Manigart et al., 2004; Bernile, Cumming, and Lyandres; 2007; Hopp and Rieder, 2006, among others). Kanniainen and Keuschnigg $(2003,2004)$ develop a model of an optimal venture capital portfolio size with a trade-off between the number of companies and intensity of advice. $^{111}$

There is empirical evidence suggesting the presence of dilution of human capital. Kaplan and Schoar (2005) find that: (1) the top performing funds in the private equity industry grow (in terms of capital under management) less in proportion to the increase in performance than do the lower performers; (2) the relationship between fund size (capital under management) and performance is increasing and concave, suggesting decreasing returns to scale; and, (3) persistence in performance. They argue that the better funds may

${ }^{111}$ Several studies consider the optimal size of venture capital portfolios. See, for example, Fulghieri and Sevilir (2005) and Bernile, Cumming, and Lyandres (2007). 
voluntarily choose to stay smaller, in order to reduce dilution of human capital: by growing relatively less rapidly than the market on a performance-adjusted basis, top funds are able to avoid moving into regions of diminishing returns. ${ }^{112}$

Similarly, Jääskeläinen, Maula, and Seppä (2006) find an inverse U-shaped relationship between the number of investments per partner and the performance of the venture capital firm (measured by the number of IPOs out of investments), suggesting the presence of an optimal portfolio size (an optimal number of investee firms per manager) beyond which the inclusion of additional portfolio companies results in negative marginal returns.

Cumming (2006) finds: (1) returns to scale are decreasing in the number of entrepreneurial firms in a venture capital portfolio, i.e., an increase in inputs (such as amount of funds raised) increases the number of portfolio companies but in a diminishing fashion; (2) the number of entrepreneurial firms in a venture capital portfolio and the number of managers in the fund are positively related; (3) venture capital funds that monitor portfolio companies more intensively (e.g., those utilizing staged financing more frequently, those investing proportionally more heavily in high-tech firms, those tending to obtain a greater ownership interest) and funds for which monitoring activity is more

\footnotetext{
112 Another possible reason Kaplan and Schoar (2005) point out is limited number of good deals in the economy at each point in time.
} 
costly (e.g., those making more out-of-province investments) have less entrepreneurial firms in their portfolios. ${ }^{113}$

Knill (2005) finds that: (1) portfolio diversification facilitates venture capital firms' growth (venture capital firms that diversify their portfolios in a greater degree show faster growth, as measured by the percentage change in value of capital under management from the previous to current years); ${ }^{114}$ however, (2) diversification imposes significantly negative influences on the probability of the investee firm's successful exit (IPO or M\&A) and significantly positive influences on the probability of the investee firm staying private. Those results are consistent with the view that diversification might limit venture capitalists' ability to advise each portfolio company effectively and efficiently.

The above studies suggest that striking a balance between portfolio diversification and effective management of investee firms is an important consideration for venture capitalists. In this regard, there are views that syndication is a means to mitigate this trade off. Jääskeläinen, Maula, and Seppä (2006) argue that syndication offers a mechanism to reduce the time required to manage an individual venture by sharing the workload with syndicate partners. In particular, by participating in syndicates as a non-lead investor and entrusting a part of the value-added and monitoring jobs to the lead investor, the venture

\footnotetext{
${ }^{113}$ Elango, Fried, Hisrich, and Polonchek (1995) report that the minimum acceptable size of an investment for large funds is 3.7 times greater than that for smaller funds ( $\$ 1.2$ versus $\$ 0.3$ million US), which implies the presence of dilution of human capital resulting from an increased number of portfolio companies.

114 Knill considers several dimensions of diversification, such as international, geographical (within the United States), across stages, across industries, and volume (through increasing number of investees in a portfolio). He also finds that international diversification offers the most extensive marginal effect, but it appears to be particularly damaging to portfolio companies.
} 
capitalist is able to increase the number of investments with a lesser negative effect on performance.

Consistent with the above view, Manigart et al. (2004) find a negative association between the number of investments per investment manager and the proportion of lead investments to total syndicated deals (Table 8). Jääskeläinen, Maula, and Seppä (2006) find that the interaction term of the syndication frequency and the number of portfolio companies per partner is positively associated with higher performance (as measured by the number of IPOs out of new company investments), supporting the hypothesis that syndication increases the number of portfolio companies a venture capitalist can effectively manage. Moreover, in a different specification, the interaction term of the frequency of syndication as a non-lead investor and the number of portfolio companies per partner is significantly and positively related to the performance, while the interaction term of the frequency of syndication as a lead investor and the number of portfolio companies per partner is not. This is consistent with the view that the effect of syndication to increase the number of portfolio companies a venture capitalist can effectively manage comes from reduced workload when participating in a syndicate in a non-lead role. 


\section{2-5-3. Trade-offs between Diversification and Portfolio Focus}

While portfolio diversification is an important means to control risk exposure by reducing unsystematic or specific risks, maintaining a high degree of specialization is also useful for controlling risk as well as for gaining access to networks, information, and deal flow from other venture investors (Norton and Tenenbaum, 1993). A trade-off, therefore, may also exist between diversification and specialization of venture capital investments. ${ }^{115} \mathrm{On}$ one hand, focusing on certain industries or investment stages has the following advantages: creating complementarities across portfolio companies (Cumming, 2006), improving venture capitalists' competencies in a particular industry (or stage) - which allows them to conduct better risk assessment and monitoring (Manigart, et al., 2002) as well as to provide the investee company with a higher quality of advice (Hopp and Rieder, 2006). Sorenson and Stuart (2001) argue that entrepreneurs at previously funded start-ups and contacts generated from working in an industry represent important sources for the identification of new investment opportunities, and that venture capitalists typically perform due diligence and monitoring more expeditiously and successfully when they have prior investment experience. However, portfolio focus reduces the dimensions across which she or he can diversify his or her portfolio. ${ }^{116}$

\footnotetext{
${ }^{115}$ Hopp and Rieder (2006) also find that venture capital firms that invest more heavily within the country exhibit a lower portfolio concentration, arguing that firms that do not invest extensively across borders receive less benefit from cross country diversification, and are, therefore, more inclined to diversify across industries within the country.

${ }^{116}$ Fulghieri and Sevilir (2005) argue that portfolio focus allows venture capitalists to reallocate resources from one start-up to another more efficiently, which is beneficial when, for example, one of the portfolio companies fails. Moreover, a high degree of portfolio focus reduces the opportunity costs of divesting (or
} 
Again, there is a view that syndication helps venture capitalists in mitigating this tradeoff. Hopp and Rieder (2006) argue that, for venture capitalists focusing on certain industries or investment stages, syndication can be a device to expand the portfolio radius without stretching their specialization over many different industries or investment stages. By syndicating investments, the venture capitalist devotes his or her effort to firms in industries of his or her specialization (acting as sole or lead investor), and invests money in other industries to achieve diversification benefits where a partner takes more effort in advising the funded firms. Hopp and Rieder (2006) find that venture capital firms that have many connections with other venture capitalists (i.e., a greater number of co-investors with whom the venture capitalist has undertaken a deal) tend to have a less concentrated portfolio. It seems that portfolio diversification is achieved through working with a greater variety of partners outside his or her scope of industries. ${ }^{117}$

terminating) a start-up at the interim stage, even when it is successful. This increases competition among portfolio companies and allows the venture capitalists to extract more rents.

Manigart et al. (2002) find that specialization is associated with lower required returns for early-stage ventures. This suggests that the positive effect of specialization (i.e., providing venture capitalists a better understanding of the specifics to a particular stage) is greater than the negative effect (i.e., decrease the level of diversification). Consistent with this view, Gupta and Sapienza (1992) find that venture capital firms specializing in early stage investments prefer less industry diversity and narrower geographic scope.

${ }^{117}$ Hopp and Rieder (2006) point out two ways in which syndication helps venture capitalists in relation to portfolio specialization. First, as mentioned above, it mitigates the negative effect of specialization, i.e., reduction of risk diversification. Second, it serves as a mean to strengthen specialized areas, i.e., syndicating with a more specialized partner can help to lever up on capabilities and competency of the venture capitalist. Manigart et al. (2004), Hopp (2006), and Hopp and Rieder (2006) find that venture capital firms specialized in particular industries are associated with a higher propensity to syndicate. Moreover, specialized venture capital firms are more likely to act as lead investors (Manigart et al.). These results are consistent with the view that syndication serves as a mean to enhance the ability to manage investee firms within the focal industries. 


\section{2-5-4. Costs of Syndication}

Lockett and Wright (2001) and Bruining, Verwaal, Lockett, Wright, and Manigart (2006) point out costs of syndication, which include:

- Increased chance of delays in decision-making: decision-making takes time as it involves discussion and re-negotiation among investors and other stakeholders, which may increase the risk of crucial decisions being delayed. ${ }^{118}$

- Higher likelihood of conflicts of interests among investors.

Both imply that the governance system of a firm backed by a syndicate is less flexible and more complex than one backed by sole investor.

Moreover, there is a possibility of agency problems, including free riding and moral hazard problems among venture capitalists in a syndicate, as well as misrepresentation of information between lead inside and follow-on outside venture capitalists (Wright and Lockett, 2003; and Cumming, 2006). Cumming finds that Canadian funds that make syndicated investments more frequently tend to have smaller number of companies in

\footnotetext{
${ }^{118}$ Bruining, Verwaal, Lockett, Wright, and Manigart argue that smaller venture capital firms may be more suited to early stage deals, where the level of uncertainty is higher and which requires capabilities to handle unexpected events, as they may be more efficient in responding to unanticipated events thanks to their structural simplicity that facilitates speed and flexibility in organizational processes.
} 
their portfolios, and attributes this somewhat surprising result to the moral hazard problems among investors. ${ }^{119}$

Those above suggest that the decision to syndicate involves a cost-benefit trade-off. The capacity to create value from the resources provided by the syndicate might be constrained by the complexity of the syndicate's governance structure (Bruining, Verwaal, Lockett, Wright, and Manigart, 2006). An addition of a venture capital firm to the syndicate increases the potential for value creation. However, the costs associated

119 There is an argument that the incentive to maintain better relationships and reputation within the banking community discourages bankers from taking moral hazard and free-riding behaviours. In the context of investment banking syndicates, Pichler and Wilhelm (2001) demonstrate that the selection of a lead banker acts as a monitoring mechanism that threatens those who might shirk in their day-to-day efforts with a loss of reputation and future quasi-rents, because: (1) there are long, stable, and informal relationships among banks, and members in different syndicates are extensively overlapped; (2) the identity of the lead banker changes from deal to deal; (3) leadership carries greater responsibility for the outcome of the deal, and thus the leader attracts attention of the community.

It seems likely that Pichler and Wilhelm's (2001) argument applies to the case of venture capital syndicates, as: (1) the network ties within venture capital community is well documented (e.g., Shane and Cable, 2002; Ferrary, 2003; Gompers, Kovner, Lerner, and Scharfstein, 2005; Hochberg, Ljungqvist, and Lu, 2007); (2) venture capital syndicates are also recurring among partners, with the participants alternating between the roles of lead and non-lead investor (Wright and Lockett, 2003; and Jääskeläinen, Maula, and Seppä, 2006); (3) reputation plays a crucial role in several aspects of venture capital process (see II-3-2-4). Jääskeläinen, Maula, and Seppä (2006) argue that the role of a lead investor is to coordinate and manage the investor group, solving the potential problem of "free riding," making sure that that the benefits of the efforts contributed to the investment are shared among all participants. Wright and Lockett (2003) argue that non-legal sanctions, especially the reputation effects linked to repeat syndication, are important in helping to minimize opportunistic behaviour by lead syndicate members, and find that potential damage to future reputations is the most important factor in getting other members of the syndicate to act in accordance with the terms of the investment agreement. Lockett and Wright (1999) find that partner selection is far more influenced by past interaction with the partner, as well as the partner's reputation and investment style than by the partner's resource-base and financial characteristics. On the other hand, Tykvová (2005) argues, based on her theoretical analysis, that syndication may be impeded in some cases because reputational concerns do not always outweigh the temptation to renege on a given contract. 
with an additional venture capitalist may outweigh the benefit such that the rate of increase may decline as the number of venture capital firms in the syndicate increases. ${ }^{120}$

\section{2-6. Conclusion - Small Size Causing Capital Constraint Problems?}

The literature reviewed in this section has suggested that there is no consensus as to whether sharing risk or acquiring additional (non-financial) resources is the dominant rationale for syndicating venture capital investments. While methodological issues might explain differences in findings, the decision to syndicate may not simply be driven by a single motivation but involve multiple factors. Motives for syndication may vary across different types of venture capitalists facing particular strategic positions with divergent resources. Others argue that venture capitalists face trade-offs between portfolio diversification and dilution of human capital, and between diversification and portfolio specialization, and that syndication helps in mitigating such tradeoffs. Syndication involves costs incurred by venture capitalists, and, therefore, the decision to syndicate requires costs-benefits analysis. All those arguments suggest that the decision to syndicate is a complex process involving several interacting factors. Those arguments also present a need to investigate the process by which venture capitalists choose syndicate partners and how syndicates are managed (Lockett and Wright, 2001).

\footnotetext{
${ }^{120}$ Those suggest that a syndicate that consists of a few large venture capital firms is more manageable and adaptive to changing conditions than a syndicate including a large number of small venture capital firms (Lockett and Wright, 2001; and Bruining, Verwaal, Lockett, Wright and Manigart, 2006), as the complexity of managerial issues and the diversity of objectives of investors are likely to increase (i.e., the flexibility of a syndicate is likely to decrease) with the number of partners in the syndicate.
} 
One limitation of existing empirical studies is that they generally assume the syndication decision is endogenous to the venture capitalist but exogenous to the entrepreneur of the firm. Results could be different, or have different implications, when the entrepreneur's participation in the decision-making process is taken into consideration. In fact, Riding's (2006a) case study describes how entrepreneurs join in the discussion on whether to add new investors to the syndicate.

Another gap in the literature is that very little research considers fund size-related capital constraints as a reason for which venture capitalists syndicate their investments. Due to its small fund size, a venture capitalist may not have enough resources on hand to fully finance large companies (or portfolio companies that have been getting large), which makes syndication inevitable. While no study thoroughly investigates this possibility, several studies report signs consistent with the idea that small venture capitalists face financial constraints (even though those studies do not explicitly acknowledge these signs). For example, the risk-sharing (portfolio diversification) motive is more important for smaller venture capital firms (Bruining, Verwaal, Lockett, Wright, and Manigart, 2006) and for firms with smaller minimum investment preferences (less than $£ 5$ million likely smaller firms) than for those with greater preferences (Lockett and Wright, 1999). Lockett and Wright argue that because venture capitalists with smaller minimum investment preference are more likely to invest in early stage firms, which are associated with higher level of uncertainty, risk diversification by syndication is more important for those venture capitalists. However, it is also possible to interpret their results as a 
reflection that availability of capital reduced by small fund size makes venture capitalists more inclined to smaller deals and syndicate investments, in order to maintain a reasonable level of diversification in a portfolio.

Based on this literature review, the only study that explicitly considers the possibility of capital constraints as a reason for venture capital syndication is that of Brander, Amit, and Antweiler (2002). They speculate on the possibility that a venture capitalist might not have enough financial resources on hand to fully finance a large entrepreneurial venture, from which syndication arises. Brander, Amit, and Antweiler find that entrepreneurial firms are typically small compared to venture capitalists (see Table II-1). They therefore conclude that capital constraints would rarely be an issue for larger venture capitalists (who are also those doing most venture capital investing), although it cannot be ruled out that in some cases such constraints could be important. ${ }^{121}$

Table II-1: Brander, Amit, and Antweiler's (2002) Size Statistics ( $\$$ CDN in millions)

\begin{tabular}{cccccc}
\hline Population & Mean & $20^{\text {th }}$ percentile & Median & $80^{\text {th }}$ percentile & Number \\
\hline Ventures & 2.74 & 0.27 & 1.04 & 3.99 & 2889 \\
Venture & 40.92 & 4.97 & 15.66 & 67.09 & 114 \\
capitalists & & & & & \\
\hline
\end{tabular}

However, Brander, Amit, and Antweiler's results (Table II-1) indicate a problem small venture capital firms may face. Very young start-ups typically require a small amount of capital; they require a larger amount as they grow. Thus, entrepreneurial firms in the $20^{\text {th }}$

${ }^{121}$ In addition, Brander, Amit, and Antweiler find that neither the total investment in the venture by all venture capitalists nor the number of employees in the venture is significantly related to the return (but the dummy variable, whether the investment is syndicated or not, is significant). Thus, they reject the possibility that syndication allows venture capitalists to invest a larger amount of capital, giving rise to larger ventures, and thus realizes higher returns. 
percentile in the Brander, Amit, and Antweiler's statistics are likely to be young, and those in the $80^{\text {th }}$ percentile are mature. In this case, the fact that larger ventures are significant in size relative to the smaller venture capitalists, as illustrated by their statistics, suggests that small venture capitalists become unable to provide necessary capital to their investee firms as those firms grow, unless they syndicate in later rounds. Brander, Amit, and Antweiler indeed report that syndication occurs at the early growth stage or later more commonly than at the seed or start-up stage, consistent with this argument). In other words, the statistics suggest smaller venture capitalists' inability to grow their investee firms into a mature corporation suitable for an appropriate, profitable exit.

The plausibility of this argument is supported by such empirical evidence as: (1) early stage deals and smaller venture capital firms are associated (Bruining, Verwaal, Lockett, Wright, and Manigart, 2006, Table 2); and, as mentioned, (2) the financial motive is more important for smaller venture capital firms (Bruining, Verwaal, Lockett, Wright, and Manigart, 2006) and for firms with smaller minimum investment preferences (Lockett and Wright, 1999); and, (3) syndication occurs at the early growth stage or later more commonly than at the seed or start-up stage (Brander, Amit, and Antweiler, 2002). Lockett and Wright (1999) report that venture capitalists with smaller minimum investment preferences (likely smaller firms) score "the requirement for additional rounds of financing", as well as "the larger size of the deal in proportion to the size of funds available," as factors in influencing their decision to syndicate significantly more 
importantly than those with greater preferences. Hopp (2006) finds that the amount of capital infusion is greater and the interim to the next financing round is longer when a financing round is syndicated than when it is made by a single venture capital firm. While Hopp views this finding as an indication that syndication mitigates informational asymmetry, but it is also possible to interpret this as a reflection that syndication allows for a greater capital infusion at a time. Riding (2006a) reports that small funds typically make relatively small investments requiring more frequent tranches of investment, due to their limited ability to invest large sums. Finally, the geographic difference in empirical findings (i.e., American studies find the resource-based motive the dominant determinant for syndication, while European studies find risk diversification a major purpose) may be a reflection that European venture capitalists, which presumably manage smaller funds than the American counterpart, are constrained in financial resources, which makes the risk diversification motive more important for them. ${ }^{122}$

Smaller venture capital firms' inability to bring up their investee firms to be suitable for an profitable exit may not be a problem if two conditions are met: (1) a large venture capital firm, which is able to provide large capital infusion in later rounds, can be easily found; ${ }^{123}$ and (2) there is no hold up problem by the entrant (later stage investor) against

\footnotetext{
${ }^{122}$ Bygrave and Quill (2007) report that, in 2005, 71 percent of all the venture capital invested among the G7 nations was in the United States, and that while the average amount of venture capital invested per company in the United States was $\$ 8.6$ million US, the average among the other G7 countries was $\$ 1.8$ million US per company (Bygrave and Quill, 2007).

${ }^{123}$ Hopp and Rieder (2006) argue that syndication combines the financial resources of the foreign investor with the skills and expertise of local venture capitalists. Their argument may be suggestive of the scarcity of large funds in the German market as well as the difficulty German venture capitalists face in finding later stage investors.
} 
the incumbent small venture capitalists (early stage investor). It would be difficult to meet the first condition if the venture capital community is mainly comprised of small funds, and/or the majority of large funds in the community are government affiliated. ${ }^{124}$ Both are the case in Canada. Riding's case study (2006a) describes venture capitalists' (and entrepreneurs') struggle to find additional syndication partners who are able to invest large amounts of capital.

Inaccessibility to 'larger pocket' investors within the local market would lead venture capitalists to search for such capital outside. In fact, all entrepreneurial firms reported in Riding's case study (2006a) at least consider American funds as potential investors. Thomson Financial (2008) presents 2007's top ten largest venture capital deals (deal sizes ranging from $\$ 23.6$ to $\$ 160$ million $\mathrm{CDN}$ with average $\$ 63.1$ million $\mathrm{CDN}$ ), and reports that foreign investors participated in all of those ten deals and they provided, collectively, 76 percent of the total dollar amount invested in those ten companies.

Relying on foreign (American) funds would not be a problem for Canadian venture capitalists if there were no hold up problem associated with it. ${ }^{125}$ However, Riding

\footnotetext{
${ }^{124}$ Syndicating investments with a large number of small funds is costly (see II-2-5-4), and statutory constraints under which government-affiliated funds operate may prevent them from taking the deals originated by independent funds. For example, all LSVCCs are constrained to invest in the sponsoring jurisdiction, and entrepreneurial firms eligible for LSVCC investment are typically restricted in terms of the nature of business such as size and industry (see II-1-2-3). Brander, Egan, and Hellmann (2008) document segmentation in the Canadian venture capital market: only nine percent of all deals originated by private funds ever receive any funding from government-affiliated funds. Similarly, only 15 percent of all deals originated by government-affiliated funds ever receive any funding from private funds. The segmentation of the market appears more dramatic for low technology firms than for high technology firms.

${ }^{125}$ Bruining, Verwaal, Lockett, Wright, and Manigart (2006) argue that syndication networks may help to combine the relative strengths of small and large venture capitalists. Smaller venture capitalists can use their relative advantage in flexibility and niche-filling capacity in early stage investments, and may deliver
} 
(2006b) argues that when small venture capitalists bring in larger venture capitalists on their deals, their inability to supply enough capital may put them in a weaker position at the negotiation table. Riding's argument is supported by Manigart et al. (2004), who find empirical evidence indicative of a positive relation between the amount of money that an investor is able to bring to the table and its power in a syndicate, and they speculate that investors contributing a small amount - often early stage investors - lose their position as lead investor in subsequent financing rounds when larger amounts are invested. ${ }^{126}$ In his report on Silicon Valley's movement, Hibbard (2004) forecasts "[m]ost of the big venture capital firms will use smaller ones as pipelines to deliver them promising new companies to invest in."

If these are the situations smaller venture capital firms face, small fund sizes - inability to bring up their investee firms to be suitable for an exit - is a serious problem, given that venture capitalists realize most of their returns through successful exits. This dissertation tests this hypothesis. Before Chapter III presents the testable hypotheses and their conceptual rationales, the next section reviews the literature on venture capital exit, in order to establish a solid background necessary for the examination of how capital constraints induced by small fund sizes, if exist, affect venture capitalists' exit decisions.

promising seeds and start-ups to larger venture capitalists that are able to provide large sums of money at subsequent financing rounds. This dissertation argues that such collaboration may work if large venture capitalists do not hold up the smaller ones.

${ }^{126}$ Manigart et al. (2004) find that venture capital firms investing larger amounts in a single project do not syndicate more than those investing smaller amounts but act more often as leads of their syndicates. Similarly, Wright and Lockett (2003) find that lead investors are more likely to have larger equity stakes, which gives him or her residual powers. 


\section{Exit Activities in Venture Capital}

The preponderance of venture capitalists' returns arises in the form of capital gains when they exit their investments. Successful exits are therefore vital to ensuring attractive returns for investors in venture capital funds and to future fundraising. ${ }^{127}$ Indeed, the existing literature provides evidence that the ability to make a profitable exit lies at the heart of the venture capital investing process (Black and Gilson, 1998; MacMillan, Siegel, and Narasimha, 1985, Carter and Van Auken, 1994; Kahn, 1987; Bruno and Tyebjee, 1985; among others). Understanding the means by, and process through which, venture capitalists exit their investments is crucial to an understanding of the entire venture capital process as well as the financial markets for early-stage capital in a country.

This section reviews the literature on the venture capital exit process. It focuses on factors influencing the means by which venture capitalists exit their investments. The first subsection (3-1) outlines the five major means of venture capital exit. The second and third subsections (3-2 and 3-3) summarize previous studies with respect to factors influencing venture capitalists exit outcomes and time to exit. This section concludes with a search for existing studies' empirical observations that could be signs that

\footnotetext{
${ }^{127}$ Most venture capital funds are closed end, requiring liquidation of the investments before the end of the fund's life. Aghion, Bolton, and Tirole (2004) point out additional reasons why exit is important. First, successful start-ups generally require new capital for their further growth beyond the capacity venture capital funds could provide. Second, venture capital managers usually do not have special expertise in managing matured firms.
} 
financial constraints induced by small fund sizes affect venture capital investment exits (3-4).

\section{3-1. Types of Venture Capital Investment Exits}

In general, venture capitalists exit their investments by one of the following five methods (Cumming and MacIntosh, 2002).

1. Initial Public Offerings (IPOs), the sale of shares of the firm to public investors for the first time, generally accompanied by a listing on a stock exchange. ${ }^{128}$

2. Merger and Acquisitions (M\&As) through which the entire firm is sold to a third party. ${ }^{129}$ In the majority of cases the purchaser is a strategic acquiror. ${ }^{130}$

3. Secondary sale through which the venture capitalist sells his or her shares to a third party. A secondary sale differs from an M\&A in that only the shares of the venture capitalist are sold to the third party; the entrepreneur and other investors retain their investments. The seller is often a minority shareholder, i.e., a non-

\footnotetext{
${ }^{128}$ The venture capitalist generally retains its shares at the date of the public offering, selling shares into the market in the months or years following the IPO (Barry et al., 1990; and Megginson and Weiss, 1991; and Lin and Smith, 1998).

${ }^{129}$ Following most studies on venture capital exit, this dissertation uses the terms "an M\&A" and "an acquisition" interchangeably (strictly speaking, an acquisition is the establishment of control in one business entity by another, and a merger is the strategic combination of one business entity with another (CVCA. http://www.cvca.ca/resources/glossary.aspx, accessed April 2, 2009)).

${ }^{130}$ A strategic acquirer is an entity in a business complementary to that of the acquired firm and intends to meld the firm's product or technology with its own in order to create synergistic gains. It is typically larger and often has some prior contractual relationship with the acquired enterprise or it may be a competitor, supplier or customer.
} 
controlling venture capitalist. The buyer is typically a strategic acquiror (in many cases with a view to making a future acquisition if the technology proves successful), and in some (relatively infrequent) cases another venture capitalist.

4. Buyback in which the venture capitalist sells his or her shares back to the entrepreneur or the company.

5. Write-offs involving the failure (bankruptcy and consequent disappearance) of the firm.

An IPO is usually considered the most profitable (and thus most desirable) means of exit (Barry, 1994). An IPO is also generally viewed as an exit vehicle exclusively for rapid growth firms that need the large current and future capital investments that public markets can supply on a large scale while spreading risk (e.g., Pagano, Panetta, and Zingales, 1998; Cumming and MacIntosh, 2002). The other side of the situation is that firms must have sufficiently attractive investment projects available to justify their need for new funds, which may restrict the availability of an IPO to firms surpassing a hurdle growth rate. IPOs may be limited to the "most promising ventures" or "home runs" from which venture capitalists derive most of their returns (Cumming and Macintosh, 2002; Schwienbacher, 2005).

Cumming and MacIntosh (2002) report that exit values are highest for IPOs and lowest for write-offs in both Canada and the United States. Das, Jagannathan, and Sarin (2003) find that the exit multiples of venture capital-backed firms (the ratio of the value of the 
firm upon successful exit to the amount of financing) for acquired firms are usually much lower than multiples for IPOs.

An M\&A is usually recognized as the second most desirable form of exit. It may be attractive when the entrepreneurial firm fails to meet the hurdle growth rate demanded by the public market or when it is too small to be of interest to institutional investors (Cumming and McIntosh, 2002). An M\&A may represent a more common exit route than an IPO as it is not only for the "most promising" but also for "less promising" ventures (Schwienbacher, 2005). While this is the generally held view, in some situations M\&As could be more appealing than IPOs. Black and Gilson (1998) and Cumming and McIntosh (2002) maintain that an M\&A might provide higher rate of return than an IPO when the acquiror sees an opportunity to create synergy by combining the entrepreneurial firm's technology with those possessed by the acquiror. Likewise, Amit, Brander, and Zott (1998) and Makri, Junkunc, and Eckhardt (2007) argue that M\&A have an informational advantage: that the information asymmetry between the seller (the entrepreneur and the venture capitalist) and the buyer is relatively less severe for M\&As than IPOs, as the buyer in an M\&A is typically in a business related to that of the entrepreneurial firm.

Buybacks are often triggered by the venture capitalist's exercise of put rights embedded in the original deal contract (Cumming and McIntosh, 2002). Such rights are typically exercised when the venture capitalist is of the view that the investment no longer has significant upside potential. The underlying cause may be a function of the nature of the 
firm's technology and the market in which it competes, or of the differing preferences of the entrepreneur and the venture capitalist. A buyback puts a strain on the firm's or entrepreneur's cash resources, so it can involve substantial borrowing in order to retire the venture capitalist's shares.

While a write-off is the least desirable form of exit, it appears to occur with surprising frequency. The average venture capital fund writes off 75.3 percent of its investments (Ljungqvist and Richardson, 2003) so venture capital funds earn their capital gains from a small subset of their portfolio companies-those exited via an IPO or a sale to another company (Hochberg, Ljungqvist, and Lu, 2007).

The following subsections review previous studies regarding factors that influence venture capital exit routes, exit timing, and investment duration.

\section{3-2. Factors Affecting Exit Routes, Exit Timing, and Investment Duration}

Previous research has found that the means and timing of exit are subject to at least eight factors:

1. Information asymmetry here referring to differences in the information available to sellers of the venture-backed firm and the buyers.

2. Contractual provisions. 
3. Monitoring and involvement.

4. Reputation.

5. Network ties.

6. The Exit environment, such as stock market activities and legal environment.

7. Deal and investee firm characteristics, such as sector, alliances the investee firm has, entrepreneur's experience, and stage of firm's development.

8. Attributes of venture capital firm/fund, such as venture capitalist's experience, organizational type, compensation scheme, and other attributes, as well as "the life cycle of a venture capital fund."

\section{3-2-1. Information Asymmetry}

Information asymmetries can arguably affect both the form of exit and, within exit types, the exit valuation. Jensen and Meckling's (1976) seminal article shows that the price which prospective shareholders will pay for shares will reflect the monitoring costs and the effect of the divergence between the manager's interest and theirs. Binks and Ennew (1996) argue that enterprise growth, a common attribute of venture-backed companies, increases information asymmetry; also, Makri, Junkunc, and Eckhardt (2007) argue that the technology regime of an industry affects the extent of knowledge asymmetries 
between insiders and outsiders. Accordingly, venture capital exits may be considered as being especially subject to information asymmetries.

The literature on firms' decision to go public considers asymmetric information as one of the key factors affecting such a choice (Chemmanur and Fulghieri, 1999; Chemmanur, He, and Nandy, 2007; Roel, 1996). Amit, Brander, and Zott (1998) argue that if venture capital investments are made in situations where informational asymmetries are important, it may be difficult to sell shares in a public market where most investors are relatively uninformed. They further argue that this may lead venture capitalists to exit their investments through sales to relatively informed investors, such as to other firms in the same industry or to the venture's own management or owners. Likewise, Cumming and MacIntosh (2001b, 2002) maintain that strategic acquirors are better positioned than public investors to resolve information asymmetries, evaluate the firm's potential, monitor and discipline managers post-exit, and make strategic decisions about how best to deploy the firm's product or technology.

Conversely, Black and Gilson (1998) suggest that venture capitalists play a role in mitigating informational problems in public market offerings: that venture capitalist involvement with an investee firm is a signal of the firm's quality to outside investors. Similarly, Megginson and Weiss (1991) argue that since venture capitalists repeatedly bring firms to the public market, they can credibly stake their reputations on the quality of the issuing firms (they can certify to investors that the firms they bring to market are not overvalued). The literature provides some evidence consistent with this view: 
- Underwriters of venture-backed firms are significantly more experienced than the underwriters of comparable non-venture offerings (Barry et al., 1990; Megginson and Weiss, 1991; Lin and Smith, 1998; Bradley and Jordan, 2001; and Lee and Wahal, 2002). The underwriter compensation as well as the expenses of obtaining legal counsel, auditing services and printing (each as a percentage of the offer price) are lower and institutional holdings after the IPO are higher for venture capital-backed firms than comparable non-venture capital-backed companies (Megginson and Weiss, 1991). These results suggest that underwriters, institutional investors, and other market participants give credit to venture capitalbacked IPOs.

- Venture capitalists are able to make firms public that are younger (Megginson and Weiss, 1991; Lin and Smith, 1998; and Lee and Wahal, 2002), smaller (Lin and Smith, 1998; and Lee and Wahal, 2002), and with lower ratios of revenue to assets (Lin and Smith, 1998) than non-venture capital-backed firms.

In addition, Megginson and Weiss (1991) find that venture capital-backed firms exhibit a lower degree of short-term underpricing. Barry et al. (1990) report that IPO underpricing is negatively related to the number of venture capitalists owning equity in the issuer firm, the time the lead venture capitalist has served on the issuer firm's board, and the fraction of the issuer firm's equity owned by venture capitalists before the IPO. To the extent that informational asymmetry determines the magnitude of underpricing needed to sell shares (Ritter and Welch, 2002, and Ljungqvist, 2008), this is consistent with the view that the 
presence of a venture capital reassures public investors as to the quality of the offering and monitoring by venture capitalists is recognized by capital markets through lower underpricing.

However, empirical evidence on how information asymmetry affects venture capital investment exits is scarce and inconclusive (findings by Amit, Brander, and Zott (1998) as well as Cumming and MacIntosh $(2002,2003)$ are not compelling). The pool of literature on venture capital exits and firms' decision to go public suggest more severe information asymmetry problems in IPO exits. While venture capitalists may be able to mitigate those problems to a certain extent, asymmetric information could still potentially affect their decisions about this exit route.

\section{3-2-2. Contractual Provisions ${ }^{131}$}

Smith (2005) finds that during the initial phase of the investment relationship, venture capitalists have limited rights to initiate exit. After the initial phase, however, venture capitalists begin to exert more direct control over exit decisions by acquiring control over the board of directors and obtaining contractual exit rights (e.g., put rights). Kaplan and Stromberg (2003) provide empirical evidence that venture capital control increases in later rounds. These studies suggest increasing importance of the allocation of control

\footnotetext{
${ }^{131}$ There is substantial literature on venture capitalist-entrepreneur contracts. See II-1-1-6 and II-1-1-7.
} 
rights (specifying which party has control over the exit decision) in venture capital contracts. $^{132}$

Several studies investigate connections between contract terms and investment outcomes. However, there is little consensus among studies, making it difficult to draw an overall picture as to how contractual arrangements affect venture capital investments. For example, Cumming (2002) finds that a higher venture capital ownership percentage increases the IRRs to the venture capitalists, while Amit, Brander, and Zott (1998) observe that investee firms' performance is significantly negatively correlated with the venture capitalist's ownership share. In Cumming (2002) and Schwienbacher (2005), use of convertible securities and tight control is not associated with a favourable exit/return outcome, suggesting that they may not be optimal instruments in venture capital investments. On the other hand, Kaplan, Martel and Stromberg (2004) find that venture

\footnotetext{
${ }^{132}$ There are often conflicts of interest between the entrepreneur and the venture capitalist concerning exit. Issues associated with such conflicts include: control, dilution, and difficulties in valuing the potential of the investee firm. There may be differences of opinion, between the entrepreneur and the venture capitalist (and/or among venture capitalists) as to when an exit should be implemented, i.e., each investor may have a different sense of timing on the issue, based on facts peculiar to that investor (Aghion, Bolton, and Tirole, 2004).

Therefore, the regulation associated with exit is an important aspect of the contracting relationship between the venture capitalist and the portfolio company, and the means of providing eventual liquidity are almost always attached to securities sold in venture capital transactions (Aghion, Bolton, and Tirole, 2004). Such means include:

- Demand and piggyback registration rights, which give the venture capitalists the right to register their shares at some point or points in the future, or at the same time as the company (Sahlman, 1990).

- A put right, which gives the venture capitalist to sell his or her shares to the entrepreneur after: the elapse of a stated time period, the failure to achieve performance targets, or the failure to go public.
}

Those rights facilitate liquidity of venture capitalists' shares (Sahlman, 1990). 
capitalists that use US-style contracts (characterized by convertible securities and stronger control) fail significantly less often. ${ }^{133}$

The inconsistency described above raises the question as to what comprises the optimal contract arrangement in venture capital investments. In this regard, Gilson and Schizer (2002) argue that it is doubtful that control over exit can be fully contracted. ${ }^{134}$ Inconsistency in findings across different studies may reflect the organic dynamisms in the venture capital investment/exit process.

\section{3-2-3. Monitoring and Involvement}

Monitoring activity may also affect exit outcomes. Schwienbacher (2005) finds that IPOs are relatively more frequent among venture capitalists that are more actively involved (for example, replacing the management more frequently, requesting more reports, providing financing with shorter duration between rounds). He also suggests that, compared with American venture capital firms, European venture capitalists are less actively involved in investee firms.

\footnotetext{
${ }^{133}$ US-style contracts are those that: (1) use convertible or participating preferred; (2) include anti-dilution protection; (3) use vesting provisions; (4) have a liquidation preference; (5) have exit provisions; and (6) do not keep the founder in control of the board.

${ }^{134}$ For example, it may be extremely difficult to secure an underwriter for an IPO if the venture capitalist opposes the offering. Similarly, negotiating an acquisition may be extremely difficult if management opposes the transaction; they may be uncooperative in the buyer's due diligence activities and in transition efforts.
} 


\section{3-2-4. Reputation}

Reputation plays a crucial role in several aspects of venture capital exit process. First, reputation of a venture capital organization appears to affect its ability to raise funds in the future (Gompers and Lerner, 1999a) because a reputation for competence and honesty allows venture capitalists to establish enduring relationships with pension fund managers and other institutional investors: such investors are also among potential purchasers of venture-backed IPOs (Megginson and Weiss, 1991). The fund's reputation is also important for its own dealings with other venture capitalists in syndicating investments in portfolio companies and in negotiating with entrepreneurs (Sahlman, 1990; Lerner, 1994a; and Black and Gilson, 1998). Moreover, reputation is also a factor in forging relationships with lawyers, investment bankers, auditors and others who are capable of providing useful services to portfolio firms (Cumming and MacIntosh, 2002).

Second, the reputation of a venture capitalist also serves as an indicator of quality of its investee firms (Shiller, 1990; Lerner, 1994b). Sahlman (1990) maintains that successful venture capitalists bring instant credibility. Black and Gilson (1998) argue that talented managers are more likely to invest their human capital in a company financed by a respected venture capital fund, and suppliers are more willing to risk committing capacity and extending trade credit to a firm with respected venture capital backers. Finally, the reputation of a venture capital firm is inversely associated with underpricing (Barry et al., 1990; Lin and Smith, 1998). 
Third, reputation appears to help venture capitalists attract more promising entrepreneurial firms (Hsu, 2004).

Finally, Lin and Smith (1998) find that venture capitalist's reputation supplants the need to retain an equity position in the portfolio company after the IPO. ${ }^{135}$ In deciding whether to sell, venture capitalists balance the costs of continued managerial and monitoring involvement (including loss of opportunities to re-deploy capital and advisory talent to other entrepreneurial firms) against the possible adverse reaction to selling (e.g., market participants may interpret venture capitalists' selling decision as stock price being overvalued). ${ }^{136}$ In such a situation, only venture capitalists with established reputations can afford to sell, because their reputation limits the adverse reaction, allowing them to reassure investors that the venture capitalist is not selling merely because the stock is overpriced. Consistent with this argument, Lin and Smith find that venture capitalists without an established reputation are less likely to sell shares at the time of the IPO.

These studies suggest that venture capitalists' reputation could affect performance of their investment, which, in turn, influences reputation. Gompers (1996) argues that one efficient way of signalling ability to build reputation is to take the portfolio companies

\footnotetext{
${ }^{135}$ Venture capitalists typically retain some fraction of their equity holdings subsequent to the IPO, because the negative signal that would be sent to the market by an insider "cashing out" would prevent a successful offering (Barry et al., 1990; Megginson and Weiss, 1991; Lin and Smith, 1998).

${ }^{136}$ Barry et al. (1990) argue that by retaining their share ownership after the offering, the venture capitalists can provide assurance of continued monitoring and can credibly signal their belief in the firm's prospects. Gompers and Lerner (1999b) and Megginson and Weiss (1991) claim that the retention of large stakes of equity after the IPO is a "bonding mechanism" that increases the effectiveness of the venture capitalist's certification. These studies imply that sale of shares might convey a signal that: (1) the venture capitalist lacks confidence in the company's prospects; (2) the company is overvalued; and (3) the firm's performance will be poor in the future as it looses the venture capitalist's continued monitoring.
} 
public. He also argues that the desire to develop a good track record and reputation (for future fund raising) is stronger for younger venture capital firms, and that desire leads them to "grandstand" in an attempt to signal their ability to potential investors and build reputation. Accordingly, he hypothesizes, and finds evidence that, young venture capital firms take companies public earlier than do older venture capital firms. Hochberg, Ljungqvist, and $\mathrm{Lu}$ (2007) have recently confirmed these results.

Gompers (1996), as well as Hochberg, Ljungqvist, and Lu (2007; see also Lee and Wahal, 2002), suggest that an incentive to obtain publicity and build reputation sometimes leads venture capitalists to take actions that do not necessarily maximize their returns. Venture capitalists are willing to bear costs (premature IPOs or under pricing) in order to build good public recognition.

Venture capitalists may also have an incentive to effect an acquisition earlier than would maximize their return. Helwege and Packer (2004) point out that a benefit of IPO and acquisition is that venture capital funds can obtain a third-party valuation of their investments, which is helpful in establishing a credible measure of returns for the limited partners. An acquisition exit also provides venture capitalists publicity, although it is not as widespread as what an IPO offers (Cumming and MacIntosh, 2002), suggesting that grandstanding may also manifest itself in acquisition exits. 


\section{3-2-5. Network Ties}

Network ties feature prominently in the venture capital industry. Gompers, Kovner, Lerner, and Scharfstein (2005) argue that a critical part of venture capital practice is nurturing a network of industry contacts to identify good investment opportunities and the know-how to manage these investments, both of which come only from long-standing experience doing deals in an industry:

- Venture capitalists cultivate a deal flow based on networks of contacts and relationships (Sahlman, 1990; see II-2-2-2 and II-2-3-2) thus, through the process of information transfer, network ties influence selection of entrepreneurial firms (Shane and Cable, 2002).

- Venture capitalists draw on their networks of service providers (headhunters, patent lawyers, consultants, etc.) to help investee firms (Gorman and Sahlman, 1989, Sahlman, 1990).

- Venture capitalists maintain close ties to investment bankers who can assist with IPOs and acquisitions (Sahlman, 1990).

Hochberg, Ljungqvist, and Lu (2007) provide three reasons to expect syndication networks to improve the quality of deal flow (see II-2-2-2 and II-2-3-2):

1. Venture capitalists invite others to invest in their promising deals in expectation of future reciprocity - as Lerner's (1994a) window dressing hypothesis suggests. 
2. By checking each other's willingness to invest in potentially promising deals, venture capitalists can pool correlated signals and thereby may select better investments - as Lerner's (1994a) second opinion hypothesis suggests.

3. Individual venture capitalists tend to have investment expertise that is both sectorspecific and location-specific. Syndication helps diffuse information across sector boundaries and expands the spatial radius of exchange, allowing venture capitalists to diversify their portfolios (Sorenson and Stuart, 2001).

As well, Hochberg, Ljungqvist, and Lu (2007) offer two reasons to expect syndication networks to help venture capitalists add value to their portfolio companies:

1. Syndication networks facilitate sharing information, contacts, and resources among venture capitalists (Bygrave, 1988) through, for example, expanding the range of customers, service providers, or strategic alliance partners for their portfolio companies.

2. Syndication networks improve the chances of securing follow-on venture capital funding for portfolio companies.

Network ties and geographic location may also be important for venture capitalists to identify an appropriate merger candidate or acquirer. Gompers and Xuan (2006) document that acquirors of private venture capital-backed companies, compared to the acquirors of other private companies, tend to: (1) be larger; (2) be in the business related 
to the acquired firms (i.e., strategic acquirors); and, (3) have higher Tobin's Q. They also show that acquirors of venture capital backed companies have positive risk-adjusted stock returns over the three-year period following acquisition and continue to have high industry-adjusted capital expenditure as well as higher Tobin's Q, indicating that these firms continue to have significant investment opportunities. The results are consistent with the idea that the network ties venture capitalists possess help identify well-suited acquirors for their portfolio companies. ${ }^{137}$ These observations, together with findings of Hochberg, Ljungqvist, and Lu (2007) indicate the importance of having robust networks and being located in a well-developed entrepreneurial community for venture capital investment success.

\section{3-2-6. The Exit Environment}

\section{Stock Market Activities}

Black and Gilson (1998) and Jeng and Wells (2000) emphasize that well-developed stock and IPO markets, which permit venture capitalists to exit through IPOs, are essential for an active and well-performing venture capital market. The possibility of an IPO exit leaves the entrepreneur with the perceived opportunity of being able, ultimately, to retrieve control over the firm from the venture capitalists. In addition, the possibility of

\footnotetext{
${ }^{137}$ The results are also consistent with the view that: (1) reputational capital provided by venture capitalists help portfolio companies in attracting better acquirors; and (2) the presence of venture capitalists helps acquirors in solving adverse selection problems caused by information asymmetries.
} 
the financial returns from going public provides incentives for entrepreneurs to work harder. ${ }^{138}$ An active IPO market also provides venture capitalists more opportunities to exit portfolio companies, and is a more efficient recycling mechanism for their both financial and non-financial resources. This rationale is inherent in Michelacci and Suarez's (2004) conceptual model where a stock market facilitates business creation, innovation, and growth by allowing the recycling of "informed capital (venture capitalists' and banks' expertise, reputation, and wealth)."139

\section{Legal Environment}

La Porta et al. (1997) and Jeng and Wells (2000) find that countries with poor investor protection have smaller capital markets, and that the Rule of Law and anti-director rights have a large positive effect on the number of per capita IPOs. This result is consistent with studies that include, among others, Cumming, Schmidt, and Waltz (2006), Cumming, Fleming, and Schwienbacher (2006), and Glaeser, Johnson, and Shleifer (2001), which report that a high quality legal environment is an essential factor to speed up deal origination, facilitate syndication and control, and consequently fostering the mutual development of IPO markets and venture capital markets.

\footnotetext{
${ }^{138}$ Myers (2000) demonstrates that the decision by private equity investors to go public is rational and efficient because it reduces outside equity investors' bargaining power and thus preserves the proper incentives for the insiders who have to build the business (i.e., there is no point to go public if the new shareholders reclaim the power of the initial private investors).

${ }^{139}$ Faure-Grimaud and Gromb (2004) suggest that the expectation that the stock will be traded actively following an IPO increases venture capitalists' incentives to engage in value-enhancing activities. Aghion, Bolton, and Tirole (2004) maintain that stock markets serve not only a role as liquidity providers but also a critical role in the valuation of new ventures.
} 
In Canada, Cumming, and MacIntosh (2002) identify several factors that make Canadian venture capitalists favour American IPOs, including:

- IPO stock valuations are generally higher in the United States.

- The size of the pool of investors that an issuer company may access in, as well as the liquidity of, the American public market, are substantially greater.

- American investors have greater appetites for risk (American institutions are more willing to trade in risky technology and small stocks).

- Once the company has acquired a public profile in the United States, future financing efforts are facilitated.

- American offerings give a firm greater visibility and acceptability to potential customers (for this reason, Canadian firms sometimes reincorporate in the United States and become an American corporation). ${ }^{140}$

In this context, Riding (2006a) describes issues faced by Canadian entrepreneurial firms transforming themselves into American-based (in order to attract American investors or

${ }^{140}$ Canadian stock markets are characterized by very small issues, averaging just $\$ 2.5$ million CDN (Industry Canada, 2004), and lack of liquidity, which is likely to affect exit values (and thus returns on venture capital investments). Furthermore, it appears that characteristics of underwriters are different between Canada and the United States. Cumming and MacIntosh (2001a) claim that most underwriters in Canada are generalists (in contrast with the United States, where many small firm underwriters specialize in technology offerings, or even in particular types of technology offerings), and that generalist underwriters are less able to credibly certify the quality of IPOs. Cumming and MacIntosh (2002) argue that there may be relatively fewer underwriters willing to bring firm public in Canada than in the United States. Karolyi, Foerster and Weiner (1999) discover that accessing capital, enhancing corporate credibility, and improving corporate image are the three major reasons for Canadian firms already listed on Toronto Stock Exchange to list their stocks on American exchanges. 
American M\&A market participants). The cost of such transformation is the loss of tax advantages entitled to Canadian enterprises. Hence, legal issues are also likely to play a crucial role in international exits. ${ }^{141}$

\section{Windows of Opportunity}

It is well known that the IPO market exhibits cyclical patterns over time (also known as hot and cold issue markets), and that much of this clustering is associated with the relative valuation level of publicly traded securities (see Loughran, Ritter, and Rydqvist (1994) for an international comparison). ${ }^{142}$ There appear to be at least two possible explanations for this positive correlation between IPO volumes (i.e., the probability of a firm to go public) and the stock market valuation of firms in the same industry (Pagano, Panetta, and Zingales, 1998). First, rational investors place a high valuation on the future growth opportunities in the industry, which enhances both the demand for, and supply of, capital to new public companies. Second, entrepreneurs attempt to time the market. Ritter (1991) suggests that if there are periods in which stocks are mispriced, firms recognizing that other firms in their industry are overvalued have an incentive to go public, taking advantage of these "windows of opportunity." To the extent that entrepreneurs manage

\footnotetext{
${ }^{141}$ Schwienbacher (2005) argues that the greater propensity of investing domestically for European venture capitalists may stem from tax and legal issues, which differ significantly from country to country.

${ }_{142}$ A "hot issue market" is said to exist when either average initial returns (e.g., Ibbotson and Jaffe, 1975; Ritter, 1984; Loughran and Ritter, 2002) or the number of IPOs (e.g., Helwege and Liang, 2004; Paster and Veronesi, 2005) in a particular month is above some threshold. There appears a lead-lag relationship between average underpricing and volume: periods of high under pricing are typically followed by high IPO volume (Lowry and Schwert, 2002). However, Helwege and Liang (2004) warn about defining a hot issue period based on the average underpricing and that based on IPO volume interchangeably, as the underpricing distribution is highly skewed.
} 
to exploit this overvaluation, one would expect a firm to be more likely to go public when the market for comparable firms is particularly buoyant. ${ }^{143}$

Ritter and Welch (2002) conclude that market conditions are the most crucial factor in firms' decision to go public. Lerner (1994b) points out several benefits that successful timing of the IPO market provides to venture capitalists. First, of course, taking companies public when equity values are high escalates the returns on the investment. Second, it minimizes the dilution of the venture capitalists' ownership stake. Third, the deliberate underpricing of a new issue, which may be easier to accomplish in a hot market, may "leave a good taste" with investors. ${ }^{144}$ Lerner (1994b) provides empirical support to his argument that venture capitalists time the IPO market when taking firms public.

Lerner (1994b) also finds that experienced venture capitalists are more likely to bring firms public at market peaks than less experienced counterparts. While Lerner (1994b) interprets this as a reflection of seasoned venture capitalists' superior proficiency to time IPOs, he recognizes the possibility of alternative interpretations. One alternative rationale is that inexperienced venture capitalists may not wait until the market is optimal to take firms public because they need to signal their quality to potential investors in follow-on funds (that is, they "grandstand"). The second is that less experienced venture capitalists

${ }^{143}$ Studies find evidence consistent with the latter explanation. Those include: Loughran, Ritter, and Rydqvist (1994), Jain and Kini (1994), Rydqvist and Hogholm (1995), Rajan and Servaes (1997), Pagano, Panetta, and Zingales (1998), Lowry (2003), and Helwedge and Liang (2004).

${ }^{144}$ This is similar to the notion that greater underpricing is associated with greater publicity (Lee and Wahal, 2002) and increased analyst following (Rajan and Servaes, 1997). 
may also wish to take firms public at market peaks, but may be unable to command the attention of investment bankers (which could be plausible if underwriting services are rationed in key periods). Here, this dissertation suggests an additional interpretation of Lerner's finding; less experienced venture capitalists may wish, and have the ability, to take firms public at market peaks, but may be constrained by the shortage of capital. Inexperienced venture capitalists do not typically have a large amount of capital they can rely on (to sustain the investee firm) while waiting for the market to peak. ${ }^{145}$ While this interpretation may not apply to American venture capitalists, it may pertain to the Canadian setting where the majority of venture capitalists manage funds of less than $\$ 200$ million (as of September 2009).

Conceivably, stock market conditions might also affect the probability and the timing of other forms of exit, such as M\&As. Schwienbacher (2005) observes that in both Europe and the United States, a large number of M\&As occurred during the booming 1997 to 2000 period. This suggests that good market conditions open up more opportunity of not only IPO exits but also acquisition exits with better prices. To this point, Giot and Schwienbacher (2006) find that stock market conditions significantly reduce time to exit for all exit routes (IPOs, M\&As, and liquidation, stronger for the first two). They argue that the exit of investment tends to speed up at time of more favourable IPO market conditions, as venture capitalists are eager to capitalize on better exit chances and redirect their human capital towards new investment opportunities.

\footnotetext{
${ }^{145}$ Lerner (1994b) uses age and size of the venture capital organization as a proxy measure for experience.
} 


\section{3-2-7. Deal and Investee Firm Attributes}

Deal and investee firm characteristics that have also been found to influence exit outcomes include the following:

- Sector. While there appears to be little consistency across studies, various sets of researchers have reported sectoral effects. These include:

- Das, Jagannathan, and Sarin (2003) report that high-growth, new economy type firms have relatively lower probabilities of successful exit (an IPO or an acquisition), shorter times to exit, but higher exit multiples.

- Laine and Torstila (2003) find that funds with a traditional industry focus are associated with lower successful exit rates than those with information technology and medical (including biotechnology) focus.

o Cumming and MacIntosh (2001b) find that firms in the medical sub-sector in the high-technology industry have a longer time to exit of any form, a result consistent with the general view that medical products take longer to develop (Lerner, 1994b; Giot and Schwienbacher, 2006).

- Makri, Junkunc, and Eckhardt (2007) find that venture capitalists are more likely to exit an investee firm via M\&A when the firm competes in an industry with high levels of technological diversification and high degrees of 
cumulativeness of technological knowledge where new firms are limited to enter.

- Alliances. Entrepreneurial firms sometimes have value-added investors in addition to venture capitalists (Hochberg, Ljungqvist, and Lu, 2007). Stuart, Hoang, and Hybels (1999) find that venture capital-backed biotechnology firms with prominent strategic alliance partners and organizational equity investors (i.e., alliance partners with equity stakes in the firm) go public faster and earn greater valuations at IPO than those lack such connections.

- Entrepreneur's Experience. Gompers, Kovner, Lerner, and Scharfstein (2006) find that entrepreneurs who have previous experience in starting a venture capitalbacked company, especially those with successful experience (i.e., those who have started a previous venture-backed company that went public), are more likely to bring his/her current company public.

- Stage of Investee Firm's Development. Venture capital firms that make more early stage investments have a lower percentage of exits through IPO and a higher percentage of liquidation (Schwienbacher, 2005). Companies backed by venture capital funds with early stage-focus are significantly less likely to go public (Cumming, Fleming, Schwienbacher, 2006). Firms in later stages and later rounds have a higher probability of exit (an IPO or an acquisition), a shorter time to exit, and lower exit multiples (Das, Jagannathan, and Sarin, 2003). Similarly, net sales 
at the time of the exit are significantly and positively associated with the probability of an IPO, as opposed to an acquisition (Makri, Junkunc, and Eckhardt, 2007).

- Achievement of Milestone. Giot and Schwienbacher (2006) find that the achievement of milestones in past rounds accelerates not only an IPO or an acquisition exit but also liquidation.

- Amount Invested. Makri, Junkunc, and Eckhardt (2007) find that the total amount of capital already invested in the firm by the time of the exit are significantly and positively associated with the probability of an IPO, as opposed to an acquisition. Giot and Schwienbacher (2006) find that the larger the total amount of money received by the investee firm at the given round the shorter the time to an IPO. ${ }^{146}$

- Number of Investors. IPOs are more likely when a greater number of venture capitalists are in the syndicate (Cumming, 2002). More syndicate partners help achieve a faster exit of all types (IPO, acquisition, and liquidation) but the greatest impact is for IPOs (Giot and Schwienbacher, 2006). ${ }^{147}$

\footnotetext{
${ }^{146}$ Several different interpretations are possible for this positive association between amount invested and the probability of an IPO. Those include: (1) an IPO is easier for a firm in which a greater amount of capital has been already invested, as investors in IPO markets rely on observable attributes thought to reflect the innovation potential of these firms (Makri, Junkunc, and Eckhardt, 2007); (2) amount invested and growth of the investee firm are positively correlated, and firms at later stage of development have higher probability of an IPO exit; (3) IPOs are restricted to firms that surpass a certain hurdle size, or, IPOs are relatively more advantageous to larger firms, and that growing into a certain size requires a larger capital infusion (see III-5-2).

${ }^{147}$ The correlation between number of investors and an IPO (or an exit of any type) may be a reflection that: (1) number of syndicate members and growth of the investee firm are positively correlated (as a more
} 


\section{3-2-8. Attributes of Venture Capital Firm/Fund}

Several venture capital fund/firm characteristics have also been found to influence exit outcomes. These include the following:

- Experience. It is a generally held view that more skilled venture capitalists attract higher ability entrepreneurs, have a better deal screening, monitor, and add value ability, and provide higher quality of reputational capital to investee firms. To this perspective, Gompers, Kovner, Lerner, and Scharfstein (2005) find that investments by the most experienced venture capitalists are most responsive to public market signals of investment opportunities and investments made by experienced venture capitalists tend to be more successful in general (i.e., exited via an IPO or an acquisition). Sorensen (2007) carries out a comprehensive examination of venture capitalists' experience, and finds that experience positively influences the probability of an IPO exit. ${ }^{148}$

mature firm requires greater capital infusion, and firms at later stage of development have higher probability of (and shorter time to) an IPO or an exit of any form; (2) greater complementarities of venture capitalists' expertise available for a syndicate with a greater number of investors increase the chance of successful exit, as well as time to an exit of any form (because greater complementarities facilitate an efficient decision-making).

${ }_{148}$ Kaplan and Schoar (2005) document that: (1) performance increases with the general partner's experience (as measured by fund sequence number); and, (2) returns on venture capital funds are persistent across funds managed by the same firm. They point out several forces might make it difficult to compete with established funds: (1) established venture capitalists may have better access to deal flow (i.e., are able to invest in better investments); (2) if highly competent fund managers are scarce, differences in returns among funds, resulting from differences in the quality of management or advisory inputs that venture capitalists provide, could persist; (3) established venture capitalists may get better deal terms when negotiating with start-ups (Hsu, 2004). 
- Organizational Type. Cumming, Fleming and Schwienbacher (2006) find that bank or corporate captive venture capital firms are more likely to experience write-offs and less likely to experience IPOs. Hochberg, Ljungqvist, and Lu (2007) report that firms backed by corporate venture capitalists are significantly less likely to survive at the second investment round. Cumming, Fleming, Schwienbacher (2006) argue that captive funds typically have inefficient organizational structures relative to limited partnerships (e.g., less performancebased compensation, internal control decision-making autonomy, and conflicting objectives), which render them less suitable investments.

- Compensation. Laine and Torstila (2003) report that there is a minority of funds that do not rely only on investment performance but also charge direct fees (e.g., closing fees and service fees) from the portfolio companies. Those funds have significantly lower rates of successful exits (IPOs and acquisitions) and a lower proportion of IPO exits relative to acquisitions.

- Other Attributes. The finding that experience affects exit outcomes is consistent with several studies that examine the effects of measures that are arguably correlated with experience. These include age (Schwienbacher, 2005) and size (Cumming, Fleming, Schwienbacher, 2006 and Hochberg, Ljungqvist, and Lu, 2007), among many others (see IV-1-1-7). 
- The Life Cycle of a Venture Capital Fund (and the Fire Sale Problem). Cumming and MacIntosh (2002) argue that exit behaviour is affected by the time horizon to fund termination. As a fund approaches its termination date, pressure to exit the fund's investments, in order to return to the limited partners their capital contributions and associated profits in liquid form, increases. This may lead the venture capitalist to exit an investment via an inferior form and/or with an inferior valuation. A firm may be brought to the public market earlier than optimal. A firm that in a year or two might be suitable for the public market might instead be sold in an inferior acquisition exit, or investments that might have been exited via acquisitions might be exited via secondary sales or buybacks. Cumming and McIntosh (2002) refer to this as the "fire sale" problem. ${ }^{149}$ The only study that appears to have examined an issue related to the fire sale problem is the research pursued by Laine and Torstila (2003), who find that fund with a longer lifetime have more IPO exits relative to acquisitions. They argue that a longer lifetime allows venture capitalists to wait longer for favourable IPO market conditions; however, such a strategy has a shortcoming, i.e., waiting longer deteriorates the fund's IRR.

\footnotetext{
${ }^{149}$ In order for limited partners to assure that they receive returns in liquid form, partnership agreements often include provisions that prevent re-deployment of capital harvested from old investments into new investments (reinvestment is often allowed only in the first few years of the fund, or with the approval of the unit holders). Those provisions are a testimony to the limited partners' serious concern about the liquidity of their investments, given the opportunity costs associated with holding cash for a period that might run into years (Cumming and MacIntosh, 2002).
} 


\section{3-3 The Duration of Venture Capital Investments}

Research on venture capital investment exits is not exclusively focused on the determinants of exit route and timing. It has also investigated how long it takes from the first venture capital infusion to the investee's exit. Giot and Schwienbacher (2006) analyze the time-to-exit through IPO, M\&A, and liquidations. They find that for IPOs, the instantaneous probability of an IPO at time $t$ exhibits a strong, inverse U-shaped pattern across time (it increases very quickly and again decreases sharply right after it peaked). That is, as time flows, venture capital-backed firms first exhibit an increasing likelihood of exiting to an IPO; after having reached a plateau (after around $2.75-4.0$ years), investments that have not yet exited have progressively fewer possibilities of IPO exits as time increases. Giot and Schwienbacher (2004) interpret this as evidence that IPO candidates tend to be selected relatively quickly; if they do not achieve a public listing fast enough, their chances of doing so quickly decrease.

In contrast, hazard functions for M\&As reach their maximum much later (6.8 to 11 years), and decrease much more slowly thereafter. Giot and Schwienbacher (2004) argue that this is consistent with the view that venture capitalists first target the IPO as the preferred way of cashing out on investment, i.e., M\&As are second-best choices.

On the other hand, Das, Jagannathan, and Sarin (2003) find that the probability of an IPO is quite stable among early, expansion, and later stage investments, and that the probability of acquisition/buyout increases as firms move from the early to later stage. 
The difference in findings between the two studies may stem from differences in statistical assumptions or from the fact that Das, Jagannathan, and Sarin's (2003) sample includes not only venture capital but also buyout funds.

Cumming and MacIntosh (2001b) also investigate investment duration using American and Canadian data. They report that in Canada, the average duration of an investment that exited by acquisition is 6.94 years, by buyback 6.34 years, by IPO 5.86 years, by writeoff 4.07 years, and by a secondary sale 3.08 years. In the United States, the average duration for an investment resulting in a secondary sale is 6.33 years, acquisition 5.17 years, an IPO 4.70 years, a write-off 4.36 years, and a buyback 4.00 years. The duration to an exit by any means was statistically longer in Canada than in the United States, and average investment duration to each firm development stage (from the first venture capital investment) is also significantly longer in Canada.

\section{3-4. Conclusion - Small Size Causing Capital Constraint Problems?}

Previous studies identify a variety of factors that affect venture capitalists' exit behaviour, their choice of exit vehicle, and exit values. However, no study has explicitly considered the possibility that small venture capital funds may be limited in their financial resources and the potential impacts of such a limitation on their investment outcomes. 
There are, however, observations (presented as evidence supporting hypotheses other than small funds being financially constrained), which could possibly be interpreted as a manifestation that small venture capitalists' limited financial capacity has impacts on their investment outcomes. For example, Gompers' (1996) finding, that the time to IPO is shorter for young venture capital firms than established ones, is consistent with his grandstanding hypothesis (i.e., young venture capital firms have incentive to perform early IPOs to establish a reputation). However, this may also reflect young (often small) venture capitalists' limited financial capacity, which leads them to early IPOs seeking a deeper well of capital. Similarly, Lerner (1994b) finds that seasoned venture capitalists are more proficient at timing IPOs, which, Lerner argues, implies seasoned venture capitalists' superior ability to perceive when the market is hot. However, it may also suggest seasoned venture capitalists' greater financial capacity that allows them to time IPOs (i.e., unseasoned (small) venture capitalists' limited financial capacity does not allow them to rely on private financings when the market is unfavourable). The negative association between venture capitalists' early stage focus and the probability of an IPO, reported by Schwienbacher (2005) and Cumming, Fleming, Schwienbacher (2006), may be a manifestation that small fund sizes (small venture capitalists are likely to focus on early stage investments) limit portfolio companies' growth.

Moreover, and more importantly, there is Canadian evidence consistent with the view that venture capitalists' financial capacity has an impact on their investment performance. The value of Canadian venture capital-backed companies is substantially different 
between when they are backed solely by Canadian funds than when they are backed also by foreign (American) funds.

Table II-2: Comparison of Exit Value, Amount of Capital Infusion, and Frequency of American Exit between Companies with Foreign Investors and Those without

\begin{tabular}{lll}
\hline & Companies with Foreign Investors & Companies without Foreign Investors \\
\hline Exit Value & & \\
IPO & $\$ 152$ million CDN & $\$ 11$ million CDN \\
M\&A & $\$ 126$ million CDN & $\$ 41$ million CDN \\
\hline Amount received & & $\$ 26$ million CDN \\
IPO on TSX & $\$ 72$ million CDN & N/A \\
IPO on NASDAQ & $\$ 62$ million CDN & $\$ 13$ million CDN \\
M\&A in Canada & $\$ 28$ million CDN & $\$ 12$ million CDN \\
M\&A in US & $\$ 48$ million CDN & \\
\hline \multicolumn{2}{l}{ Frequency of American Exit } & $0 \%$ \\
IPO on NASDAQ & $22 \%$ & $48 \%$ \\
\hline
\end{tabular}

Source: Duruflé (2006).

Table II-2 is created based on Duruflé's (2006) research. It compares the average exit value, the average amount of venture capital received, and the frequency of exit located in the United States between Canadian venture capital-backed firms with foreign investors and those without. The comparisons are striking. First of all, the value of a Canadian venture capital-backed company at the time of the exit is substantially higher when it has foreign investors than when it does not. In the case of IPOs, the average exit value is 1.37 times higher for companies with foreign investors than those without, and in the case of acquisitions, it is three times higher for firms with foreign investors. Duruflé (2006) reports that overall, the average exit value for a company that has foreign investors is 2.5 times higher than that for companies without foreign investors. ${ }^{150}$

${ }^{150}$ Duruflé $(2006,2007)$ also compares exit values between Canada and the United States. 
Second, a Canadian venture capital-backed company receives a substantially larger amount of venture capital when it has foreign investors. The average amount of venture capital received by a company exited through an IPO is almost three times higher when it has foreign investors. The average amount received by a firm exited through an American M\&A is four times as high, and the average amount received by a firm exited through a Canadian M\&A is twice as high, when it has foreign investors. Duruflé (2006) observes that an investment by a foreign fund in Canada is on average three times larger than an investment by a Canadian fund. ${ }^{151}$ Moreover, the frequency for a Canadian venture capital-backed company to have an American IPO or M\&A is much higher when there are foreign investors.

These observations are consistent with the view that foreign funds' deeper pockets allow Canadian entrepreneurial firms to grow more and be of greater value at the time of their

Table II-3: Comparison of Exit Value between Canada and the United States (\$ CDN in millions)

\begin{tabular}{llll}
\hline IPOs & & & \\
& $\begin{array}{l}\text { Canadian firm listed on } \\
\text { TSX }\end{array}$ & $\begin{array}{l}\text { Canadian firm listed on } \\
\text { NASDAX }\end{array}$ & $\begin{array}{l}\text { US firm listed on } \\
\text { NASDAQ }\end{array}$ \\
\hline $\begin{array}{l}\text { Exit } \\
\text { value }\end{array}$ & 122 & 301 & 481 \\
\hline M\&As & & & \\
\hline & Canadian firm acquired by & $\begin{array}{l}\text { Canadian firm acquired by } \\
\text { US firm }\end{array}$ & US firm acquired by US \\
$\begin{array}{l}\text { Exit } \\
\text { value }\end{array}$ & 40 & 77 & 100 \\
\hline
\end{tabular}

Source: Duruflé (2006).

${ }^{151}$ Table II-4: Average Size of an Investment by a Single Investor ( $\mathrm{CDN}$ in thousands)

\begin{tabular}{lllll}
\hline & Seed & Start-up & Other early stage & Late Stage \\
\hline Foreign & 638 & 4502 & 2877 & 4207 \\
$\begin{array}{l}\text { All (Canadian and } \\
\text { Foreign) }\end{array}$ & 703 & 844 & 868 & 1216 \\
\hline
\end{tabular}

Source: Duruflé (2006). 
exits. The relatively small and thus limited financial capacity of Canadian venture capitalists may restrict the growth of their investee firms.

Large inflows of foreign venture capital would not be a problem if such inflows work only as a resolution for small sizes of Canadian funds and have no negative impacts on Canadian venture capital industry and the economy as a whole. However, as mentioned in II-2-6, Riding (2006b) argues that when small and large funds are at the negotiating table over a deal, small funds are likely to be in a weak position. He points out the possibility that foreign investors' involvement in a deal allows the Canadian entrepreneurial firm to grow, but in such a case, small (Canadian) investors, also participating in the same deal (and often the initiators of the deal, who discovered and financed the viable Canadian company at the early stage of its development), might not receive much of the benefits from it.

In fact, Duruflé (2006) shows that there are Canadian venture capital-backed companies that have generated large exit values, but a significant part of the profits goes to foreign investors. He demonstrates that during 2002 to 2005 period, foreign investors are present in 25 percent of exits, taking 45 percent of the total exit value of Canadian venture capital-backed companies. In 2006, they represent 28 percent of all M\&A exits in number and 42 percent in value, and, 40 percent of all M\&A exits located in the United States and 89 percent in value (Duruflé, 2007). These findings suggest that small sizes of Canadian venture capital funds lead to Canadian investors' reliance on large foreign 
funds and that this would, in turn, be counterproductive for further development of the Canadian venture capital industry.

Duruflé $(2006,2007)$ work, however, is suggestive and not conclusive. It is premature to conclude, from his reports, that: (1) small size of Canadian venture capital funds limits the growth of Canadian entrepreneurial firms; and (2) reliance on foreign funds has a negative influence on the Canadian venture capital industry. The difference in exit values between firms with foreign investors and those without may result from not only foreign investors' larger pockets, but alternatively from better deal selection and value-added services. For example, the higher frequency of American exits for companies with foreign investors is probably a product of American funds' better network positions in the American community. Their reputation is also likely to contribute to the higher exit values of Canadian companies exited in the United States. To what extent foreign funds' deeper pockets contribute to Canadian entrepreneurial firms' growth, and to which extent relatively small Canadian funds' limited capacity to finance restricts their growth? If, for example, foreign investors' better deal selection and value-added, rather than their deeper pockets, creates higher exit value of Canadian entrepreneurial firms, then the issue faced by the Canadian venture capital industry is not small fund size but lack of skilled fund managers. In such a case, a large inflow of foreign capital should be welcomed as it gives Canadian fund managers opportunities to learn from foreign investors through syndicating investments. 
Accordingly, further research is necessary in order to determine whether Canadian venture capitalists are limited in growing their portfolio companies and disadvantaged due to their small fund sizes. If a significant part of the profits goes to foreign investors, as Duruflé observes, is it because of Canadian venture capitalists' weak position at the negotiation table? Does the Canadian venture capital industry receive benefits from foreign investors' participation, and are such benefits greater than the costs?

This dissertation addresses the question of how small fund sizes affect syndication patterns and exit outcomes and examines plausible alternative hypotheses. The next two chapters discuss the conceptual basis, data and methodology employed to address this question. 


\section{CONCEPTUAL RATIONALES AND TESTABLE HYPOTHESES}

With very few exceptions, the investment record of early-stage funds world-wide has been very poor.

Murray, Venture Capital and Government Policy (2007)

\section{Introduction: On the Size of Venture Capital Funds}

Previous academic research has shown that there is a minimum bound for the size of a venture capital fund if reasonable rates of return are to be expected. In particular, Murray and Marriott (1998) simulate the investment activity of early stage investment funds using industry-supplied costings and probabilities of capital gains for various rounds. Figure III-1 (reproduced from Murray, 2007) illustrates the simulated relationship.

Figure III-1: Effect of Fund Size on Management's and Private Partners' Returns (reproduced from Murray \& Marriott, 1998)

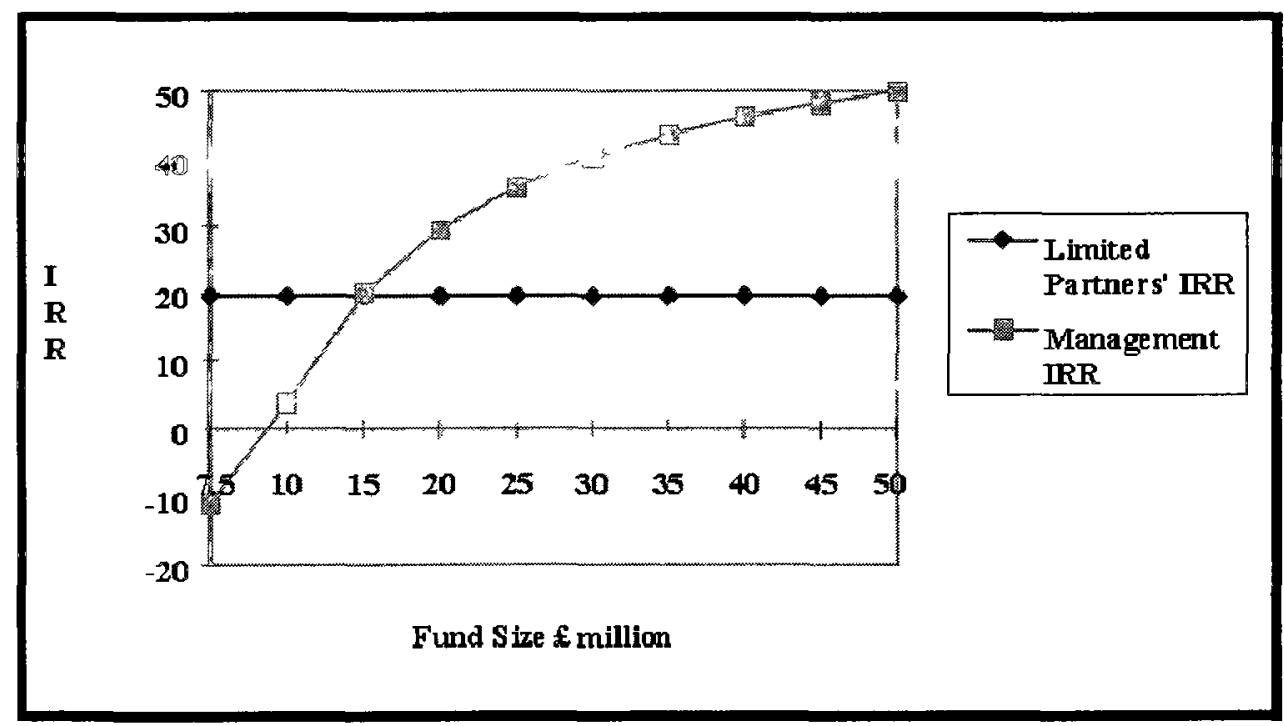


Their simulation demonstrates that fixed costs have a severe effect on the net performance of small venture capital funds. The figure shows that if the limited partners are to obtain a given return, the impact of fixed costs falls on the general partner. In further research on this topic, Dimov and Murray (2006) find that large and well established American funds are able to exploit scale and scope economies, and that the top five performing American seed capital venture capital investors are large funds, with an average of 92 seed investments and average funds under management of nearly $\$ 4$ billion US. Likewise, Söderblom and Wiklund (2005) review more than 120 academic papers, finding that large fund size is consistently associated with successful professional equity investments. By contrast, the Canadian venture capital sector is comprised of relatively small venture capital funds so findings of ongoing poor performance are consistent with this research (Duruflé, 2006; see also II-2-3-8).

In subsequent work, Murray (2007) lists the following among the disadvantages of small fund sizes:

- The high fixed costs of reducing information asymmetries in immature, complex and dynamic markets.

- The high levels of management support and guidance required by early-stage investees.

- The skewed risk/return profile resulting in the need for a substantial success by the venture capitalist. 
- The limited ability to attenuate project risks by fully diversifying the venture capital fund.

- The long development cycle and its implications on fund structure, performance and the limited ability to provide follow-on financing in a successful new firm.

- The limited ability to invest large sums early in the life cycle of the investee firm.

- The danger of excessive dilution of ownership for the original investors.

In the last four bullet points, Murray (2007) indicates the possibility that small venture capital funds - in spite of what might seem like a large amount of capital - may face capital constraints. 


\section{Capital Constraints?}

Chapter II has shown that there is a considerable body of research regarding venture capital. However, there appears to be little research that has considered the possibility that smaller venture capital funds may be limited in the amount of capital available to their portfolio companies, or about problems associated with such a financial constraint. Perhaps this is because the vast majority of research on venture capital has been in the context of the United States, where annual investment rates total $\$ 25-30$ billion CDN in 2,000-3,000 entrepreneurial firms. Arguably, capital constraints are less likely to be present in the large funds that characterize the American venture capital market.

As noted, a positive and significant association between size and performance is reported in the literature (for example, Laine and Torstila, 2003; Hochberg, Ljungqvist, and Lu, 2007), but it is generally interpreted either as a manifestation that successful past performance enables them to raise large funds (Kaplan and Schoar, 2005), or as a reflection that a larger universe of investments to choose from enables larger funds to fund more attractive opportunities (Laine and Torstila, 2003). ${ }^{152}$ Those interpretations make sense, as venture capitalists must demonstrate their talent in order to raise followon funds, and larger fund sizes enable venture capitalists to make larger individual investments while maintaining sufficient diversification (i.e., widen the size of the

\footnotetext{
${ }^{152}$ Kaplan and Schoar (2005) and Hochberg, Ljungqvist, and Lu (2007) find that the relationship between fund size and performance is increasing and concave. Kaplan and Schoar argue that fund size picks up some aspect of fund quality and/or past performance, and the better funds may voluntarily choose to stay smaller, in order to reduce dilution of human capital (see III-2-5-2).
} 
universe of investment opportunities available to the fund (Laine and Torstila, 2003)). ${ }^{\mathbf{1 5 3}}$ Nevertheless, an alternative explanation for the positive size-performance relationship-a capital constraint faced by small funds - has not been ruled out as previous studies do not control for this possibility.

Financing constraints are consistently considered a severe problem in many other areas of finance, economics, and entrepreneurship. Previous research has explored whether such constraints exist, and if so, what the consequences are. For example:

- The liquidity constraint literature suggests the presence of a financing hierarchy even among publicly traded corporations (internal funds are seen as advantageous over new equity and debt (for example, Fazzari, Hubbard, and Peterson, 1988; Hoshi, Kashyap and Scharfstein, 1991; Oliner and Rudebusch, 1992; Carpenter, Fazzari, and Peterson, 1994; and Schaller, 1993)).

- The credit rationing literature (for example, Jaffee and Russell, 1976; Jensen and Meckling, 1976; Stiglitz and Weiss, 1981; Myers and Majluf, 1984; Watson, 1984; and Williamson, 1987a, 1987b) points to factors such as information gaps in financial markets that may limit a firm's ability to raise external capital.

\footnotetext{
${ }^{153}$ Gupta and Sapienza (1992) argue that because: (1) the growth in a venture capital firm's size comes about almost exclusively through infusions of fresh capital by outside investors; and (2) new investors are unlikely to overlook the history of a venture capital firm's performance, some venture capital firms become large because they have demonstrated a successful track record in their past investments. Similarly, Barry et al. (1990) argue that to attract resources, venture capitalists must convince investors of their expertise and their ability to discover and monitor investment opportunities; the amount of resources a venture capitalist controls may therefore serve as a proxy for expertise as perceived by investors in venture capital funds. Consistent with the above view, Gompers (1996), Gompers and Lerner (1999a) and Kaplan and Scholar (2005) observe that better performing partnerships are more likely to raise follow-on funds and/or larger funds.
} 
- The literature of small- and medium-sized business financing generally views small firms as being relatively more subject to information asymmetry so they have more difficulty obtaining capital, or suffer from higher cost of capital.

- There might be some types of enterprises such as growing firms and firms with high R\&D intensity, for which risk assessment is more difficult and for which access to finance is, therefore, even more restricted (for example, Binks and Ennew, 1996, Westhead and Storey, 1997; Moore, 1994; and Oakey, 1984).

- In the entrepreneurial activity literature, there appears to be a positive association between the probability of people becoming self-employed and their available assets (for example, Evans and Jovanovic, 1989; Bernhardt, 1994; and Blanchflower and Oswald, 1998), and a positive association between owners' personal assets and their firms' survival rate (Evans and Jovanovic, 1989; Black, de Meza, and Jeffreys, 1996; Blanchflower and Oswald 1998; Holts-Eakin et al., 1994a, 1994b), suggesting the presence of financial constraints.

- Cooley and Quadrini (2001) show that capital constraints can potentially explain why small firms pay lower dividends, are more highly levered, have higher Tobin's $\mathrm{Q}$, invest more, and have investments that are more sensitive to cash flows (see also, Cabral and Mata, 2003; Desal, Gompers and Lerner, 2006; and Parker and Praag, 2005). 
It therefore seems hard to believe that capital constraints may be so generally prevalentbut not for venture capital financing. Yet no study appears to have taken into account the possibility of capital constraints with respect to venture capital syndication and exits.

Due to small fund sizes, prudent diversification limits the amount of capital that each fund can allocate to any one investment. As investee firms grow and require larger amounts of financing, venture capitalists, as well as the managements of the investee firms, face challenges as to how to fill the gap between the amounts required and what incumbent investors can afford to provide. This chapter contemplates this "bottleneck" hypothesis, developing a theoretical framework of the impacts of small fund sizes and consequent capital constraints on venture capital syndication and exit practices. 


\section{The Bottleneck Hypothesis}

In a series of case studies, Riding (2006a) records challenges faced by the founders of Canadian enterprises and their venture capital providers when the firms grow and require additional capital for further growth. Riding (2006a,b) hypothesizes that small funds may be limited in the amount of capital that a given fund can allocate to an investee firm, weakening the funds' ability to bring an investee firm to an optimal exit by itself. This compels syndication; however, large venture capital funds are rare in Canada and are often limited in terms of geographical reach (especially true of labour-sponsored venture capital corporations). Thus, when substantive growth of an investee firm requires more financing than its current investors can provide, the firm, together with its investor syndicate, may have to resort to wider syndication and even to foreign sources of capital.

While syndication holds advantages, syndicating in order to alleviate capital constraints may disadvantage incumbent investors, including earlier-stage venture capitalists, business angels, and founders. New investors have a vested interest in driving down the valuations of the incumbents' investment, diluting incumbents' interests and reducing their rates of return at exit. ${ }^{154}$ This may also create dysfunctional conflicts within the governance team. At the extreme, early investors and founders may be tempted to sell the firm, rather than invite new large investors to the syndicate. Selling the firm may be a

\footnotetext{
${ }^{154}$ The term "an incumbent" or "an early stage" investor refers to a risk capital supplier that has already invested in an entrepreneurial firm. The term "a new", "an entrant" or "a later stage" investor refers to an investor who enters into a deal, initiated by an incumbent venture capitalist, at a later stage.
} 
rational alternative to dilution and being under-funded in the face of entrenched wellfinanced competitors. ${ }^{155}$

The following sections develop a conceptual framework for venture capitalists' syndication practice (section four) and exit behaviours (section five) when venture capital funds are small and thus restricted in the amount of capital they can allocate to an investee. Those sections consider how financial constraints consequent on small fund sizes increase the necessity of syndication and hinder venture capitalists from making full use of their ability to grow the investee firm and bring it to an optimal exit, especially in an environment where large funds are rare. The final section (section six) synthesizes the discussions and proposes a model describing a sequence of events triggered by small venture capital fund sizes. It forms a vicious circle where capital constraints in an environment with a scarcity of large funds result in unprofitable exits, which discourages venture capital fundraising activity and thus promotes small fund sizes. This sequence of events is termed the "bottleneck chain".

155 This explanation is consistent with the widespread belief that Canadian firms sell out early to foreign acquirers. 


\section{Syndication Practice}

This section considers the impacts of fund size on venture capital syndication behavior. Capital constraints are defined such that the less financing a venture capitalist can provide to each of its portfolio companies, the greater the capital constraint. First, following on the previous discussion, it is hypothesized that smaller venture capital funds are more likely to be financially constrained.

Hypothesis 1: Smaller venture capital funds are more likely to be capital constrained (that is, to have smaller amounts of capital available to each of its portfolio companies).

Part of the rationale for Hypothesis 1 has been provided by Murray and Marriott (1998) and Dimov and Murray (2006) in their work regarding scale and scope economies (see section one of this chapter).

Another rationale is that a venture capital fund must maintain a minimum number of investee firms in its portfolio. There are at least two reasons for this requirement. The first reason relates to contractual constraints on venture capital funds that often proscribe the placement of more than a given proportion (often ten percent) of the fund in any one investment (Murray, 1999). The second reason is associated with the need for maintaining a reasonable level of diversification. According to Huntsman and Hoban's (1980) simulation results: ten investments are probably inadequate to obtain relatively 
stable portfolio returns for venture capital portfolios. ${ }^{156}$ Because the number of companies needed for portfolio diversification is relatively inelastic to its size, less capital under management implies less capital that the venture capital fund can allocate to any one portfolio company. Consistent with this, Elango, Fried, Hisrich, and Polonchek (1995) report that the maximum acceptable size of an investment is seven times greater for large funds than that for small funds (\$9.7 versus $\$ 1.4$ million US). Laine and Torstila (2003) argue that larger funds are able to make larger individual investments while maintaining sufficient diversification and therefore large investment opportunities are available only to large funds. From this, it seems logical that smaller funds face constraints on the amount of capital it can invest in an individual investee firm.

To the extent that small funds are systemically unable to allocate sufficient financing to its investee firms founders and incumbent investors must seek additional sources of financing. This implies that smaller venture capital funds are more likely to syndicate investments. Accordingly, the second hypothesis advanced is that:

Hypothesis 2: Small venture capital funds syndicate more often.

Previous results consistent with this hypothesis include the findings of Bruining, Verwaal, Lockett, Wright and Manigart (2006) and Lockett and Wright (1999), findings that may reflect that smaller funds have less money available to each investee firm due to

\footnotetext{
${ }^{156}$ Huntsman and Hoban also conclude that adequate diversification for portfolios consisting of new or very young companies requires greater minimal capital levels than may be the case for portfolios containing more mature enterprises with readily marketable securities.
} 
diversification needs; hence, syndication becomes necessary to provide sufficient financing to portfolio companies.

An entrepreneurial firm typically requires greater amounts of venture capital as it grows (Duruflé, 2007; Giot and Schwienbacher, 2004; Gompers, 1995; Lockett and Wright, 2001). Thus, the growth of an investee firm increases the likelihood that the amount of capital the firm requires exceeds the venture capitalist(s)' capacity, and therefore the likelihood that the venture capitalist(s) (and the entrepreneur) must seek an additional investor(s) who can fill the difference between what the firm requires and what the incumbent investor(s) can provide. ${ }^{157}$ Hence, the third hypothesis is:

\section{Hypothesis 3: The frequency of syndication is higher for later financing rounds (as investee firms grow).}

A large number of investors is necessary to combine each investor's resources and provide sufficient financing when venture capital funds are small. It has been argued that venture capitalists prefer a small number of investors in a syndicate to a large number; however, it can be hypothesized that small venture capital funds are compelled to syndicate with large numbers of investors when prospective syndicate partners are also small funds (possibly to the point where costs associated with forming and managing a syndicate are high). An investee firm requires more capital as it grows; this tendency will be stronger. Thus:

\footnotetext{
${ }^{157}$ Giot and Schwienbacher (2006) find that most venture capital deals are syndicated and the size of the syndicate tends to become larger as the investee firm gets more developed and requires a greater amount of capital.
} 
Hypothesis 4: A larger number of investors are involved in syndicates comprised of smaller funds (especially for later stages of financing as the investee firms grow).

Costs of syndication are higher when many participants are involved, not only because of the fixed costs associated with any one addition of syndicate partner but also due to (see II-2-5-4): higher levels of agency problems; increased risk of conflicts of interests and of delayed decision-making; and potential diffusion of control (Bruining, Verwaal, Lockett, Wright and Manigart, 2006; Cumming, 2006; Lockett and Wright, 2001; Wright and Lockett, 2003). This, as noted, suggests that venture capitalists prefer a syndicate consisting of a small number of investors to one comprised of many participants, and thus further implies that the entrant investor is likely sufficiently large when it joins a syndicate in order to ensure follow-on financing of a deal originates by small venture capital funds. Bruining, Verwaal, Lockett, Wright and Manigart (2006) argue that this type of syndicate formation may combine the relative strengths of small and large investors. Smaller venture capitalists can use their relative advantage in flexibility and niche-filling capacity in early stage investments, and may deliver promising seed and start-up opportunities to larger venture capitalists that are able to provide large sums of money at subsequent financing rounds. This leads to the following hypothesis:

Hypothesis 5a: The smaller the incumbent investor(s), the more likely that a new investor added to the syndicate is larger than the incumbent(s), especially at later stages of financing (as the investee firm grows).

While Hypothesis $5 a$ contends that small venture capital funds have reason to look to larger funds as a first choice of syndicate partner, there are also reasons to expect 
incumbent investors to seek syndicate partners from within the immediate "community." Chapter II has revealed the importance of network ties in venture capital investments (see 2-3-2 and 3-2-5 in particular). Within a community, venture capitalists are repeat players exchanging information and introducing promising deals to each other, thereby reducing uncertainty (Bygrave, 1988; Florida and Kenney, 1988; Lerner, 1994a). Hence, a critical part of venture capital investing is maintaining the network of industry contacts (Gompers, Kovner, Lerner, and Scharfstein, 2005) and geographic clustering of venture capitalists enhances their ability to share information, make deals, and mobilize resources quickly (Florida and Kenney, 1988).

It is therefore expected that when a venture capitalist seeks additional investors, it prefers to do so from within its networked community. Offering an investment opportunity to a venture capitalist in the same community allows building further close ties (Hochberg, Ljungqvist, and Lu, 2007), minimizes the risk of conflicts of interests among investors, and reduces agency costs (Seppä and Jääskeläinen, 2002). Seppä and Jääskeläinen (2002) argue that forming alliances among actors that have previously co-operated with each other can significantly reduce the quality uncertainty about partners and Lockett and Wright (1999) note that partner selection is influenced by previous interactions and partners' reputations for trustworthiness. Costs associated with searching a new investor are also arguably lower when venture capitalists do so within their community.

These are compelling arguments. They beg the question, therefore, of why venture capital funds ever syndicate from outside their communities. Yet, recent Canadian experience is 
that foreign investors (especially those from the United States) are a significant and growing presence and are more likely to be in later stage deals than early-stage investments (Industry Canada, 2004; see II-1-2-3). One explanation, hypothesized here, is that with the Canadian community comprised mainly of small funds it may be difficult to find a large investor with sufficient financial resources. This may oblige Canadian funds to seek sources of capital from beyond the community, especially in later rounds.

This may be reinforced if foreign investors (for example, those based in the United States) operate within an environment of a relatively plentiful supply of venture capital. From the viewpoint of outsiders, opportunities to invest in later round deals outside of their community might be attractive if the outsider is situated in a community experiencing an increase in commitments to venture capital, as - until quite recently has been the case for the United States venture capital industry. Any one fund manager can only monitor a given number of deals and effectively serve on a limited number of boards. Moreover, the supply of fund managers is inelastic in the short-run. Therefore, an increase in capital available to the venture capital community may make venture capital firms human resource constrained (Kanniainen and Keuschnigg, 2003, 2004; Cumming and MacIntosh, 2001), This may intensify pressure to make larger investments, 
increasing demand for the limited supply of promising later round investment opportunities within the outsider community (Gompers, 1998). ${ }^{158}$

In summary, small and financially constrained venture capitalists in a community with few large funds may (be obliged to) seek deeper pockets externally in order to finance later stage deals. Meanwhile, venture capitalists in an industry having plenty of large funds and experiencing a rise in commitments are under pressure to finance later stage companies. This induces a flow of venture capital between the two communities, from the latter to the former. This may be the case between Canada and the United States. At the micro level, it is predicted that when a venture capitalist is small, limited in financial resources, and part of an industry with scarcity of large funds, it initially seeks additional investors from within the local industry; however, as the investee firm grows and requires yet more financing, it resorts to sources of capital from beyond the local community.

Hypothesis 5b: When incumbent investors are small and are part of a community comprising relatively few large funds, foreign venture capital funds are more likely to participate at later stages of financing (as the investee firms grow).

The next section considers how small fund sizes and subsequent capital constraints may affects venture capital investment exit outcomes.

\footnotetext{
${ }^{158}$ Gompers and Lerner (2000) show a strong positive relation between the valuation of venture capital investments and capital inflows. Lauterbach, Welpe, Calanog, and Wahrenburg (2006) report that increased capital inflows increase amount per financing round and funds' speed of capital allocation.
} 


\section{Venture Capital Exits}

\section{5-1. Conceptual Rationale}

This section considers how the size, and thus capital availability, of a venture capital fund may affect its investment outcomes. The discussion develops a series of testable hypotheses based on research questions regarding:

1. How fund size affects a venture capitalist's bargaining power and agency costs associated with operating a syndicate, both of which may affect the timing and type of exit;

2. How venture fund size may impact the investee firm's growth, which, in turn, affects the likelihood and type of exit; and,

3. How the structure of the venture capital community influences the impacts of small fund sizes considered above.

As discussed, the need to add new investors to a deal in which the incumbent is financially limited is a setting in which the bargaining power of the incumbent is weak relative to that of a potential entrant. Potential entrants seek to "buy low" to improve their rates of return (thereby reducing the incumbents' rates of return), resulting in a dilution of the incumbents' interests. According to Murray (1999: 360),

"[t]he parlous financial position of the original VC investor makes the negotiation over the pricing of equity to the follow-on co-investor potentially difficult. In an 
extreme case, the original investor may have to accept an aggressively low equity revaluation and thus a significant dilution of the seed fund's initial investment in order to persuade the necessary follow-on investor to participate in the deal".

Under these circumstances the incumbent early stage investors bear the highest level of risk but potentially receive inadequate compensation (Murray, 1999). Duruflé's (2006) findings (for example, that foreign investors took 45 percent of the total exit value of Canadian venture capital-backed companies but were present in only 25 percent of exits) are consistent with the view that large foreign funds drive down values of early stage investments taking advantage of their stronger bargaining power. ${ }^{159}$

As noted, small fund sizes may compromise growth potential of portfolio firms, for four reasons.

1. The time and energy of the founder(s) and early investor(s) are diverted from development of the firm to seeking out additional financing.

2. Conflicts among stakeholders may result and these could negatively affect venture capital investors' value-added activities and increase uncertainty associated with

\footnotetext{
${ }^{159}$ Under the assumption that the venture capitalists are not financially constrained, Admati and Pfleiderer (1994) argue that entrants are in general informationally disadvantaged, which may boost the incumbents' interest in driving up the firm's valuation when entrants are added, resulting in a higher returns for the incumbents at the cost of the entrants' returns. We argue that, in the presence of financial constraints, such an opportunistic behaviour may not be feasible for small incumbent funds.
} 
the firm's future growth. Excessive dilution may reduce the motivation and efforts of the founding team. ${ }^{160}$

3. Small fund sizes may result in underinvestment if additional sources of capital are not found or if the early stage investors are averse to the participation of large investors (anticipating dilution of their interests and potential dysfunctional conflicts). ${ }^{161}$ In addition, small funds typically make relatively small investments requiring more frequent tranches of investment, due to their limited ability to invest large sums. ${ }^{162}$ These dynamics may place the firm at a competitive disadvantage with respect to better-funded competitors.

4. Finally, early stage investors - anticipating dilution of their interests and potential dysfunctional conflicts - may rationally prefer to sell the investee firm at a premature stage of development, rather than being "crammed down" by new entrants.

All of these outcomes potentially reduce the growth potential and the chance of a successful exit (an IPO in particular) of investee firms.

\footnotetext{
${ }^{160}$ Even if the entrant's undervaluation does not occur, costs associated with managing the syndicate increases if it consists of a large number of investors, which could negatively affect investors' value-adding activities (see II-2-5-4).

${ }^{161}$ The risk of the firm is also increased because of greater uncertainty about the feasibility of follow-on rounds.

${ }^{162}$ Hopp (2006) finds that the amount of capital infusion is greater and the duration to the next financing round is longer when a financing round is syndicated than when it is made by a single venture capital firm.
} 
Finally, we argue that the possible impacts of small funds sizes, as conjectured above, are more likely to manifest when the small fund is situated in the context of a community where large funds are rare. This is because the dilution of the incumbent investors' interests is especially likely to follow when a new entrant comes from outside of the community of the incumbent.

As discussed in the previous section (section four of this chapter, also see II-2-5-4, II-3-24, and II-3-2-5), venture capitalists are repeat players within the community and driving down the value of an investment opportunity originated by a local colleague not only reduces the likelihood that the colleague will offer useful information or good deals again, but also harms the venture capitalist's reputation and threatens the position it has established within the network. Thus, when the entrant is located in the same community as the incumbent, the reputational effects may reduce the extent to which an entrant holds up an incumbent. Moreover, an outside entrant is more likely to be invited when the incumbent is in a community consisting mainly of small funds, that is, where the supply of large size financings is scarce (as posited in Hypothesis $4 b$ ). This gives the entrant more monopoly power and a yet stronger incentive to hold up the incumbent (Rajan, 1992; and Pagano, Panetta, and Zingales, 1998).

Hence, dilution of incumbent investors' interests is more likely brought about by an outsider entrant, yet small venture capital funds in a community short of large funds may have no choice but to rely on foreign investors if they want to take the investee firm to the optimal exit. They are therefore more likely to experience the dilution of their 
interests and dysfunctional conflicts among investors when inviting a new investor to their syndicate. Anticipating those possible outcomes, small funds in such a community may choose premature exits from their investments rather than further capital infusions with additional large investors. This, plus more difficulty in finding an additional large source of capital and the higher possibility that it is not found, all imply that investee firms are more likely limited in growth when backed by small venture capital funds in a community where large funds are rare.

The following section proposes testable hypotheses based on the above arguments.

\section{5-2. Testable Hypotheses}

The preceding section argues that small fund sizes and consequent liquidity constraints may reduce the likelihood and extent of firm growth. A successful exit requires the firm to be of a relatively large size; hence restricted growth is likely to decrease the chance of successful exits (acquisitions and IPOs) and increase the likelihood of unsuccessful ones (write offs and buybacks). Hence:

Hypothesis 6: Entrepreneurial firms backed by small funds receive smaller amounts of venture capital than those backed by large funds by the time of their exits.

Hypothesis 7: Successful exits are less likely when early investors are small funds. 
It is also follows that, between the two forms of "successful" exit (IPOs and acquisitions), lower growth of an entrepreneurial firm due to its investors' small fund sizes decreases the relative likelihood of an IPO, and increases the relative probability of exits by acquisition or merger.

\section{Hypothesis 8: Relative to IPO exits, acquisition exits are more likely when early investors are small.}

The rationale for Hypotheses 8 is that a firm must achieve a particular level of development in order to reach the point for either an IPO or an acquisition exit (Cochrane, 2005; Giot and Schwienbacher, 2006), and the required level of development is higher for an IPO than for an acquisition exit (Gompers, 1995; Makri, Junkunc, and Eckhardt, 2007; Schwienbacher, 2005). Gompers (1995), Giot and Schwienbacher (2006) and Makri, Junkunc, and Eckhardt (2007) have found that the total quantity of venture capital received is significantly positively associated with the likelihood of an IPO exit but not with the likelihood of an M\&A exit. To the extent that small fund sizes slow the growth of investee firms and decrease the likelihood of becoming sufficiently large for an IPO, small fund sizes increase the possibility of an M\&A while reducing the chance of an IPO. Moreover, it has been also noted that incumbent (early stage) investors might prefer to sell an investee firm early over seeking additional financing that dilutes their holdings. This argument therefore suggests that small fund sizes increase the possibility of an M\&A while decreasing the chance of an IPO. 
Studies also suggest that, while there is a threshold scale for going public, just exceeding the threshold may not be enough to reap the full benefits of an IPO exit. IPOs are relatively more advantageous to larger or older firms (Cumming and MacIntosh, 2002; Gompers, 1996; Megginson and Weiss, 1991; Pagano, Panetta, and Zingales, 1998; Ritter, 1987). However, for the reasons advanced above, small fund sizes may hinder the investee from growing to this level. Adding a new, large investor to the deal may solve the small funds' liquidity constraints and enable them to grow the investee to that level, but they may prefer an earlier exit to further syndication, in anticipation of dilution of interests and dysfunctional conflicts by an additional investor.

The above discussion leads to the hypothesis that IPOs backed by smaller funds are less mature (smaller in size) than those backed by large funds with abundant financial resources. Gompers (1996) finds that young venture capital firms bring their investee companies public earlier than older ones. He argues that this could be young venture capital firms' effort to establish a reputation and to help raise capital for new funds. However, this may also be due to limited financial resources young (and thus typically small) venture capital firms have available. Small venture capitalists may also have an urgent necessity to exit the firm, in order to provide financing to their other portfolio companies.

Furthermore, the strategy that venture capitalists often seek (to bring firms public at market peaks (Lerner, 1994b)), is possible only when the venture capitalist has financial resources to draw from while valuations are low. If small venture capitalists are less able 
to time the market, due to their limited available capital, valuations of firms at the time of the offering will tend to be relatively lower for those brought forward by small venture capitalists. Also for this reason, it is hypothesized that the value (size) of the investee at the time of IPO is lower for those backed by small venture capitalists than those with deeper pocket investors.

A parallel argument can be applied to the case of an M\&A exit. That is: small venture capital funds, due to their limited availability of capital, are more likely to sell the investee firm for a price lower than the price for which they could possibly sell it in the future. Younger firms have shorter track records, less information available for evaluation by potential buyers, and thus are surrounded by greater uncertainty (Gompers, 1996). Those suggest that there are costs associated with a premature M\&A exit. However, venture capitalists with small fund sizes may find it difficult to grow the investee firm sufficiently large to take the full advantage of an M\&A exit. As it is the case for an IPO, small incumbent venture capitalists may avoid adding a new large investor, with which they could grow the investee to a high level, in anticipation of dilution of interests and dysfunctional conflicts from adding an investor. These arguments prompt Hypotheses 9 and 10.

Hypothesis 9: Firms backed by small venture capital funds are smaller than those backed by large funds, in terms of market capitalization or issue size at the time of their IPOs.

Hypothesis 10: The price at which a portfolio company is acquired is lower for firms backed by small venture capital funds than those backed by large funds. 
When a small fund is located in a setting in which large funds are rare, it is more difficult to find an additional large source of capital. Thus, small funds' problems of diversion of management time and effort as well as underinvestment are more likely to manifest in a community short of large funds. In addition, new large investors are more likely to drive down the valuations of the incumbent venture capitalists and the entrepreneur when they are outsiders with respect to the community of the incumbent (when the new investor is located within the same community as the incumbent, reputational effects may militate against a new investor from opportunistic actions). This implies that potential consequences of adding a new large investor are more likely to be experienced by small venture capital funds in a community with scarcity of large funds (as it obliges small funds to rely on foreign investors). For such funds, adding a large foreign investor could result in dilution of their interests and dysfunctional conflicts, yet not adding a foreign investor could bring about underinvestment and potentially a premature exit - in either case the growth of portfolio companies may be compromised. Taken together, the effects of small fund sizes predicted in this subsection (i.e., Hypothesis $6 \sim 10$ ) are more likely to be manifest in a community comprised by a relatively small number of large funds and a large number of small funds.

Hypothesis 11: The effects of capital constraints specified in Hypothesis 6, 7, 8, 9, and 10 are more likely to manifest in a community or industry comprised of small funds than in a community or an industry of large funds. 
The Canadian venture capital sector consists of a large number of small funds and a small number of large funds. Hence, these hypotheses may explain why the percentage of unsuccessful exits (write offs and buybacks) is greater for Canada (50.7 percent) than for the United States (34.8 percent, Cumming and MacIntosh, 2002). Low rates of return are also an important issue associated with the Canadian industry (see II-1-2-8). Duruflé (2006) finds that a significant part of the profits generated by Canadian venture capitalbacked companies goes to foreign investors (see II-3-4). Those are observations consistent with the view that small fund sizes and scarcity of large funds in a venture capital market lead to relatively unsuccessful investment outcomes for the reasons discussed above. However, this dynamic has not yet been fully investigated. ${ }^{163}$ This dissertation seeks to address this gap.

${ }^{163}$ For the comparison of successful exit rates, Cumming and MacIntosh (2002) neither condition on size nor control for other factors influencing the probability of a successful exit such as experience of venture capitalists. It is therefore premature to attribute Canada's poor performance (relative to the United States) to its structural deficiency. Similarly, Duruflé (2006) does not scrutinize what is going on behind his finding. 


\section{The Bottleneck Chain}

Previous sections have considered the impacts of small fund sizes on venture capitalists' syndication practices and exit activities in an environment where large funds are rare. In this final section, the discussion is summarized and synthesized into a sequence of events. Figure III-2 illustrates this sequence, starting with a small fund size that restricts the amount of capital the venture capitalists can allocate to an investee firm.

As hypothesized, a small venture capitalist is likely to encounter a situation where the amount of capital necessary for an investee firm's growth exceeds the amount of capital it can provide. This requires the venture capitalist (and the founder(s)) to add new sources of financing to a deal. However, searching for additional financing is costly and diverts the founder's and investors' time and energy from development of the entrepreneurial firm. Moreover, even if an additional source of capital is found, there might be some negative consequences following an addition of a new investor. Entrant investors have a vested interest in driving down the valuations of the incumbent investors' investments. It is argued here that incumbent investors must add investors to a deal in order to take the portfolio company to an optimal exit. This weakens the incumbents' bargaining power against the entrant, boosting the entrant's incentive to drive down the valuation of incumbents' investments and thus dilute their shares. This may further bring about dysfunctional conflicts within the governance team. 
Those consequences are more likely to follow when the entrant is an outsider with respect to the incumbents' community. Entrants are more likely to undervalue the incumbents' investments when they are outsiders, as reputational effects prevent insider entrants from opportunistic behaviours. For this reason (and because of lower agency and search costs associated with alliances within network ties) incumbent venture capitalists prefer an entrant who is within its community. However, it is difficult to find a sufficiently large, local, additional source of capital when the community is short of large funds.

Those arguments suggest that small funds are disadvantaged especially when they are surrounded by an environment where large funds are rare. They invest in very early stage firms, bearing the highest level of risk. Then, they must incur costs associated with searching for additional (large) sources of capital as the investee firm grows and requires a larger amount of financing; such costs including diversion of management time and effort. If a large investor is found within their community, the incumbent venture capitalists' liquidity constrain problems are resolved. In the Canadian setting, however, this is unlikely because of the scarcity of large funds. Thus, incumbent investors are obliged to seek sources of capital outside of the community, even if costs are higher for an inter-community rather than an intra-community search. If an additional deeper-pocket investor is not found, underinvestment problems arise. Even if it an investor is found, addition of an outside investor brings about dilution of incumbents' interests. Or, anticipating those negative consequences, the early stage investors are averse to the participation of large investors. Whichever case follows, the growth of the portfolio 
company is compromised. Thus, the bottleneck hypothesis predicts that small venture capital funds increase the likelihood of less profitable forms of exit and thus lower returns on those funds, especially when they are in a community with scarcity of large funds. ${ }^{164}$

Because the industry is comprised of many small funds, low returns on small funds are translated into low returns on the industry as a whole, this, in turn, discourages venture capital fundraising. Here, the sequence of events closes, forming a vicious cycle - small fund sizes result in less profitable exits and low returns that discourage venture capital fundraising activity, which causes venture capitalists to have small funds. This sequence is referred to as the "bottleneck chain".

This bears significant implications for the community. A bottlenecked sector ultimately dissuades wealthy individuals from making early stage investments, discourages individuals with good ideas from starting businesses and limits growth prospects for existing firms. These results weaken the entrepreneurial base of the community.

This dissertation empirically tests this "bottleneck chain" in the Canadian context. The Canadian venture capital industry is an ideal case, as it is comprised of a relatively large number of small funds and a small number of large funds, and Canadian venture capital funds invest substantially smaller amounts than their American counterparts in each of their portfolio companies (see II-1-2-1). Thus, whether small fund sizes result in unfavourable investment outcomes via liquidity constraints, and whether this is

\footnotetext{
${ }^{164}$ Additions of large investors may make it possible to take the investee firm to an optimal exit, but returns to early stage investors might be low if such additions bring about dilution of their shares.
} 
exacerbated by the absence of large funds are examined here. The following chapter discusses the data and the methodology employed. 
Figure III-2: The Bottleneck Chain

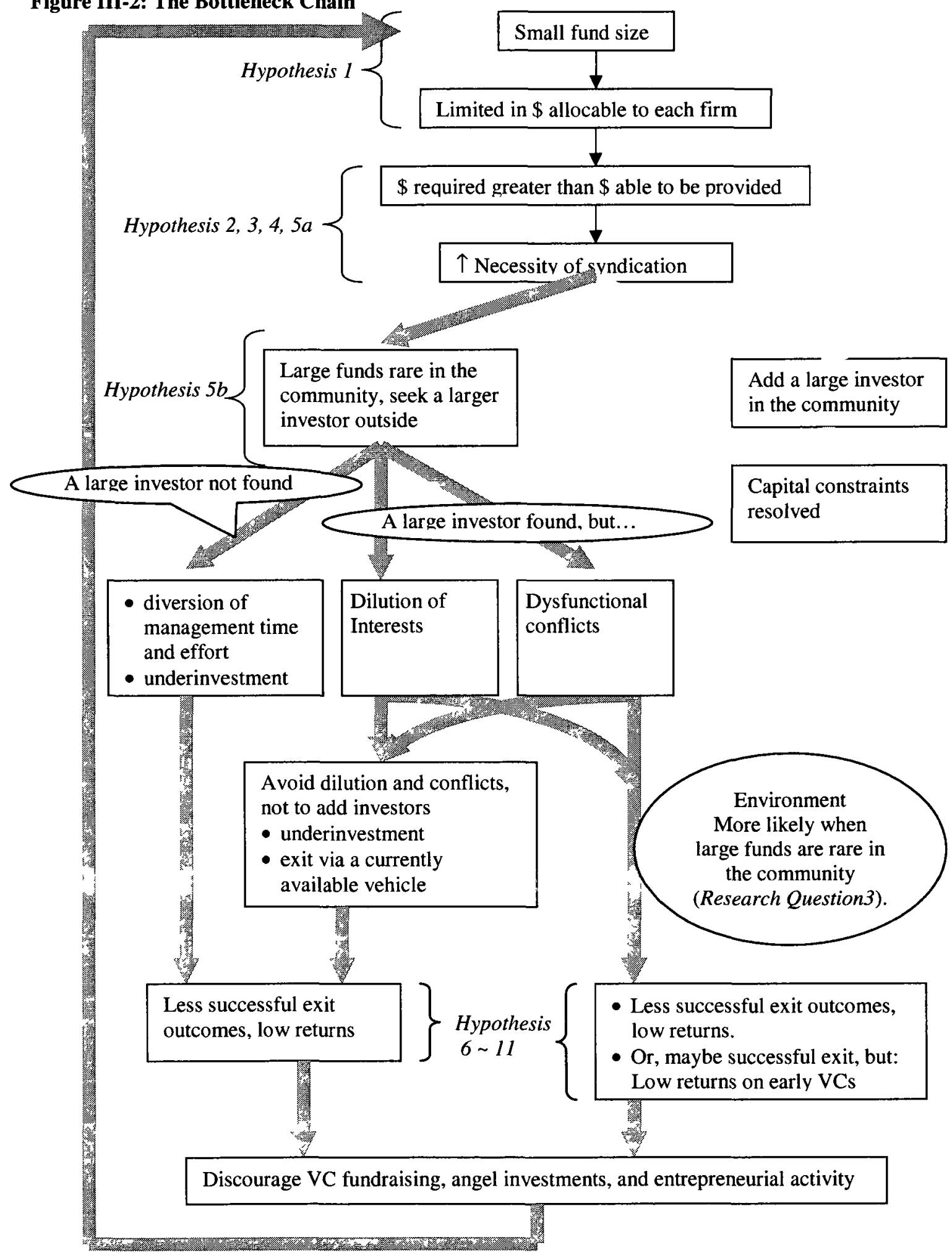




\section{DATA}

This chapter describes the data used for this research. The three datasets employed are introduced in the first section; and, salient descriptive statistics are presented in the second.

\section{Data}

The empirical analyses in this dissertation used three datasets:

1. Thomson-Reuters Financial VCReporter data for Canadian funds;

2. Venture Economics SDC (Securities Data Company) Platform data for American and Canadian funds; and,

3. MoneyTree Report data for American funds, data which, in turn, was sourced from Venture Economics, a division of Thomson-Reuters.

The Thomson Financial Canadian data was used for the Canadian analyses and for testing all the hypotheses proposed within the Canadian venture capital industry. The latter two datasets were used for the analyses comparing Canadian and American practices. The following three sub-subsections describe the datasets in turn. 


\section{1-1. Thomson Financial VCReporter}

The Thomson Financial VCReporter database provides six search engines, enabling the extraction of six data tables, including:

1. A list of venture capital transactions made by Canadian funds since January $1^{\text {st }}$, 1999 ("Deal" data);

2. A list of venture capital-backed IPOs and M\&As in Canada since January $1^{\text {st }}$, 1999 ("Exit" data);

3. A list of Canadian venture capital firms that have made investments since January $1^{\text {st }}, 1999$ ("Management Company" data);

4. A list of Canadian venture capital funds that have made investments since January 1st, 1999 ("Fund" data);

5. A list of the amount raised and the amount of capital under management every year for Canadian funds since January 1st, 2001 ("Capital Supply" data); and,

6. A list of companies that have received financing by Canadian venture capital funds since January 1, 1999 ("Portfolio Company" data).

In addition, VCReporter has a keyword search facility that facilitates access to details on venture capital firms, funds, and portfolio companies. The information contained in each of the above six datasets and that extracted using the keyword search facility, were 
combined in a way suitable for the analyses of Canadian venture capital syndications and exit practices. Table IV-5 lists the specific variables provided by each of the six data tables. The variables available through the keyword search are listed in Table IV-6. Table IV-7 summarizes all the variables available via the six datasets and the keyword search facility.

\section{1-2. Venture Economics SDC Platform}

The Venture Economics SDC Platform data was used for US-Canada comparisons of the number of portfolio companies as part of the testing of Hypothesis 1. The platform provides a list of Canadian and American private equity funds as of December $31^{\text {st }}, 2009$. The list contains 374 Canadian and 9,418 American funds, along with the following information on each: name of the management company of the fund, size (amount of capital under management), investment stage focus, year fund founded, known amount invested, number of companies invested, fund sequence number, and fund raising status. From this list, classic venture capital funds were extracted (5,334 American and 237 Canadian funds) and used for the analysis. ${ }^{165}$

\footnotetext{
${ }^{165}$ That is: buyout, mezzanine, and other "non-"classic" venture capital funds were excluded. For the
} definitions of private equity and classic venture capital funds, see II-1-1-2. 


\section{1-3. MoneyTree Report}

Every calendar quarter, the MoneyTree Report reports all the venture capital deals that occurred in the United States during the preceding quarter. A list of all the entrepreneurial firms in the United States that received venture capital financing during the first quarter of 2010 was downloaded from this report. ${ }^{166}$ The downloaded list contains information on the amount invested, the number of investors, and the investment stage associated with each deal. The data were used for the part of Hypothesis 4 that compared Canadian and American funds in relation to the number of investors involved per deal.

${ }^{166}$ https://www.pwcmoneytree.com/MTPublic/ns/index.jsp 


\section{Descriptive Statistics}

This section reports the salient descriptive statistics for Canadian venture capital investments. The statistics are based on the data extracted from the Thomson Financial VCReporter database.

According to Thomson Financial VCReporter, 6,472 investments were made by Canadian venture capital/private equity funds in 3,225 entrepreneurial companies during the period between January 1999 and December 2009. Of those investments, the following are excluded from the analyses:

- Investments in non-Canadian companies; ${ }^{167}$

- Investments in companies that received one or more acquisitions/buyouts and/or turnaround/consolidation financing; ${ }^{168}$

- Investments in companies for which investors are all unknown for all financing rounds;

- Investments made in 1999 and 2000; ${ }^{169}$

- Investments in companies that received venture capital financing prior to $1999 ;^{170}$

\footnotetext{
${ }^{167}$ Motives for syndication and factors influencing exit decisions are arguably different between domestic and international investments.

${ }_{168}$ The focus of this study is on classic venture capital (see II-1-1-2).

${ }^{169}$ Thomson Financial VCReporter "Capital Supply" data, which provides information on fund size (capital under management), covers the period from 2001 to present. Thus, data on fund size is unavailable for deals made in 1999 and 2000 . The other reason to exclude 1999 and 2000 is the possibility that venture capital funds behaved differently during the Internet bubble period.

${ }^{170}$ Data were unavailable for deals made prior to January 1999. Moreover, in many cases, companies that received venture capital prior to 1999 are old, with long time-lags between successive investment rounds.
} 
- Investments that were made after the firm was exited; and,

- Investments in public companies. ${ }^{171}$

After those exclusions, 2,315 investments in 1,240 companies remain in the data.

\section{2-1. Investee Companies}

Table IV-1 provides a breakdown by industry and location of the 1,240 venture capitalbacked companies in the data.

Table IV-1: Industry and Location Breakdowns of Investee Firm

\begin{tabular}{lrrlrr}
\hline Industry & Frequency & Percent & Province & Frequency & Percent \\
\hline Life Sciences & 209 & 16.9 & AB & 74 & 6 \\
IT & 575 & 46.4 & BC & 134 & 10.8 \\
Other & 122 & 9.8 & MB & 39 & 3.1 \\
Technologies & & & & & \\
Traditional & 334 & 26.9 & NB & 32 & 2.6 \\
Total & 1240 & 100 & NF & 5 & 0.4 \\
& & & NS & 31 & 2.5 \\
& & & ON & 396 & 31.9 \\
& & PE & 1 & 0.1 \\
& & QC & 492 & 39.7 \\
& & SK & 36 & 2.9 \\
& & & Total & 1240 & 100 \\
\hline
\end{tabular}

Consistent with the notion that venture capital is generally characterized as financing for high-risk, high-return investments and thus is associated with high-technology

For example, one such company founded in 1989 received its first venture capital investment in 1993 and its follow-on investment in 2002.

${ }^{171}$ See II-1-1-1 for definitions of venture capital. 
entrepreneurial firms (see II-1-1-1), Canadian venture capital investments are concentrated in high-technology companies. Almost three quarters of the investments were in life sciences, IT, and other technology sectors. ${ }^{172}$ As expected (see II-1-2-2), venture capital-backed companies were concentrated in Quebec and Ontario, followed by British Columbia. The three Prairie provinces (Alberta, Manitoba, and Saskatchewan) had 149 venture capital-backed companies collectively, and the four Atlantic provinces (New Brunswick, Newfoundland, Nova Scotia, and Prince Edward Island) had only 69.

\section{2-2. Investment Deals}

Among the 2,315 venture capital investments, 1,431 (61.8 percent) were follow-on investments. ${ }^{173}$ Foreign venture capital funds participated in 521 deals (22.5 percent).

The frequency of venture capital investments appears to be decreasing over time (Table IV-2). Until 2007, the number of investments was decreasing but the average amount invested per round was increasing. However, in 2008 and 2009, both the number of investments and the amount invested dropped. In 2009, there were only 62 venture

\footnotetext{
172 "Life Sciences" includes biopharmaceuticals, healthcare, medical devices and equipment, and medical/biotech software and information services. "IT" includes communications and networking, electronics and computer hardware, internet focus, semiconductors, software, and other IT services. "Other Technologies" includes energy and environmental technologies and other technologies. "Traditional" includes consumer and business services, consumer products, finance, manufacturing, retailers, and miscellaneous.

${ }^{173} \mathrm{~A}$ follow-on investment is a supplementary round of financing in a portfolio company that builds on its original financing, generally in line with business growth and development (CVCA, http://www.cvca.ca/resources/glossary.aspx, accessed Oct. 19, 2009). Venture capital-backed companies are often engaged in multiple follow-on financings (see II-1-1-8, "Staged Investment").
} 
capital investments, with an average amount of $\$ 6.3$ million CDN invested per round. The following rationale may explain the recent decrease. First, the so-called global financial crisis has prompted a generalized tightening of all financial markets as well as a move to less risky forms of investment. Second, recent legislative changes, and announcements of pending changes, have effectively diminished the attractiveness of LSVCCs such that LSVCC funds' ability to raise further capital has been reduced substantially. ${ }^{174}$ Finally, the low rates of return that have characterized the venture capital sector have curtailed financial institutions' willingness to subscribe to new funds.

Table IV-2 also exhibits a high level of syndication activity in the Canadian venture capital industry. While the frequency of syndication varies over time, syndicated deals have accounted for 64.5 to 83.5 percent of all deals, and the average amount of venture capital invested per deal is significantly greater for syndicated investments than for sole investments. ${ }^{175}$ In $2007,83.5$ percent of investments were syndicated, the highest rate observed between 2001 and 2009), and the average amount invested for syndicated investments also reached its peak of $\$ 10.7$ million CDN.

\footnotetext{
174 The Ontario government reduced the percentage of the tax credit granted to the investors in LSVCC funds, and announced its further reduction over the next ten years.

${ }^{175} \mathrm{t}$-tests show the significance in differences for all years.
} 
Table IV-2: Number of Investments and Average Amount Invested per Year

\begin{tabular}{|c|c|c|c|c|c|c|c|c|c|c|}
\hline & Total & & & Sole & Investmer & & Syndi & ated Inve & tments & \\
\hline Year & $\mathbf{N}$ & $\begin{array}{l}\text { Mean } \\
\text { Amount } \\
\text { Invested }\end{array}$ & S.E & $\bar{N}$ & $\begin{array}{l}\text { Mean } \\
\text { Amount } \\
\text { Invested }\end{array}$ & S.E & $\mathbf{N}$ & $\begin{array}{l}\text { Mean } \\
\text { Amount } \\
\text { Invested }\end{array}$ & S.E & $\begin{array}{l}\% \\
\text { Syndicated }\end{array}$ \\
\hline 2001 & 470 & 5.08 & 0.5501 & 154 & 1.03 & 0.1176 & 316 & 7.05 & 0.7933 & $67.23 \%$ \\
\hline 2002 & 366 & 5.00 & 0.5478 & 102 & 1.40 & 0.2761 & 264 & 6.38 & 0.7347 & $72.13 \%$ \\
\hline 2003 & 209 & 4.44 & 0.4392 & 45 & 1.07 & 0.2941 & 164 & 5.37 & 0.5318 & $78.47 \%$ \\
\hline 2004 & 154 & 6.31 & 0.8222 & 36 & 1.38 & 0.1844 & 118 & 7.81 & 1.0335 & $76.62 \%$ \\
\hline 2005 & 139 & 6.61 & 0.8494 & 37 & 1.67 & 0.5367 & 102 & 8.39 & 1.0895 & $73.38 \%$ \\
\hline 2006 & 118 & 6.85 & 0.7222 & 25 & 1.95 & 0.3486 & 93 & 8.17 & 0.8625 & $78.81 \%$ \\
\hline 2007 & 121 & 9.30 & 1.3056 & 20 & 2.17 & 0.3324 & 101 & 10.71 & 1.5251 & $83.47 \%$ \\
\hline 2008 & 106 & 5.81 & 0.5736 & 25 & 2.45 & 0.6356 & 81 & 6.84 & 0.6863 & $76.42 \%$ \\
\hline 2009 & 62 & 6.32 & 1.0197 & 22 & 4.60 & 1.7752 & 40 & 7.27 & 1.2339 & $64.52 \%$ \\
\hline Total & 1745 & 5.72 & 0.2480 & 466 & 1.54 & 0.1327 & 1279 & 7.24 & 0.3246 & $73.30 \%$ \\
\hline
\end{tabular}

* Mean Amount Invested is the average dollar amount of venture capital invested per deal (in million CDN).

* Total number of observations is less than 2,315 due to missing values for the amount invested variable.

\section{2-3. Venture Capital Funds/Firm}

Among the 2,315 venture capital transactions used for the analyses, 373 Canadian and 404 foreign funds were involved. Of the Canadian venture capital funds, 202 funds (54.2 percent) were private independent limited partnerships, 69 (18.5 percent) were corporateaffiliated (such as institutional, corporate financial, or corporate industrial investors), 54 (14.5 percent) were government affiliated, including LSVCCs and provincial venture capital corporations, ${ }^{176}$ and 31 (8.3 percent) were government funds. ${ }^{177}$ Geographically,

\footnotetext{
176 Government affiliated funds are those established with the benefit of government tax credits to individuals. Government funds are those organized through a federal or provincial agency or crown corporation (see II-1-2-3).

${ }^{177}$ Type of fund is unknown for 17 funds.
} 
168 funds (45.0 percent) were located in Ontario, 62 (16.6 percent) were in British Columbia, 92 (24.7 percent) were in Quebec, and 45 (12.1 percent) were in either the Prairie or Atlantic provinces. ${ }^{178}$

Table IV-3 shows that "large" funds (those with capital under management of at least $\$ 165$ million $\mathrm{CDN}$ ) are concentrated in Quebec and Ontario. In particular, the six largest venture capital funds are all located in Quebec, the size of which ranges from $\$ 723$ million CDN to $\$ 17.8$ billion CDN (see Table IV-4 below for the list of the 29 top funds in Canada). ${ }^{179}$ Compared with these "big six", the size of large funds located in other provinces ranges from $\$ 170$ to 470 million CDN with the average being $\$ 296$ million CDN. There are only two "large" funds in Alberta, one in each Saskatchewan and Manitoba, and none in the Atlantic provinces.

\footnotetext{
${ }^{178}$ Location is unknown for 6 funds.

${ }^{179}$ In terms of the number of funds, Quebec is not dominated by government-affiliated funds. However, in terms of activity, Quebec is dominated by government-related venture capital funds. This is because of the presence of Fonds de solidarité (FTQ) National as well as Regional, Capital regional et cooperative, and FondAction, which collectively participated in 448 out of 866 deals made in Quebec.

Ontario has a relatively large number of government-affiliated funds. This is probably because, unlike other provinces, Ontario has no restriction on the number of funds within its jurisdiction that can be sponsored by trade unions or associations (Hebb and Mackenzie, 2001; see II-1-2-5).
} 
Table IV-3: Size, Type, and Geographic Distribution of Canadian VC Funds

\begin{tabular}{|c|c|c|c|c|c|c|}
\hline & & \multicolumn{4}{|c|}{ Type of Fund } & Total \\
\hline \multirow{3}{*}{$\begin{array}{l}\text { Size } \\
\text { Category } \\
\mathbf{x}<\mathbf{3 0}\end{array}$} & & Private & Corporate & Government & Government & \\
\hline & & Independent & Affiliated & Affiliated & & \\
\hline & ON & 19 & 0 & 6 & 0 & 25 \\
\hline & BC & 7 & l & 8 & 0 & 16 \\
\hline & QC & 6 & 1 & 0 & 0 & 7 \\
\hline & Other & 7 & 0 & 1 & 1 & 9 \\
\hline & Total & 39 & 2 & 15 & 1 & 57 \\
\hline $30<=x<75$ & ON & 11 & 2 & 8 & 0 & 21 \\
\hline & $\mathrm{BC}$ & 7 & 1 & 5 & 0 & 13 \\
\hline & QC & 8 & 3 & 0 & 0 & 11 \\
\hline & Other & 5 & 0 & 0 & 1 & 6 \\
\hline & Total & 31 & 6 & 13 & 1 & 51 \\
\hline $75<=x<165$ & ON & 11 & 1 & 6 & 0 & 18 \\
\hline & BC & 3 & 0 & 1 & 1 & 5 \\
\hline & QC & 8 & 1 & 0 & 2 & 11 \\
\hline & Other & 2 & 0 & 3 & 1 & 6 \\
\hline & Total & 24 & 2 & 10 & 4 & 40 \\
\hline $165<=x$ & ON & 4 & 2 & 2 & 1 & 9 \\
\hline & BC & 2 & 1 & 2 & 0 & 5 \\
\hline & QC & 2 & 3 & 4 & 2 & 11 \\
\hline & $\begin{array}{l}\text { Prairies } \\
\text { and } \\
\text { MT }\end{array}$ & 3 & 0 & 0 & 1 & 4 \\
\hline & Total & 11 & 6 & 8 & 4 & 29 \\
\hline
\end{tabular}

Table IV-4 demonstrates that "large" funds generally have a high number of entrepreneurial firms in their portfolios (except for private independent funds). Of the 2,315 venture capital transactions used for the analyses in this study, the "big six" funds participated in 890 deals (38.4 percent), eight "large" government affiliated funds showed up themselves in 746 deals ( 32 percent), and the total of 29 "large" funds were involved 
in 1,375 deals (59 percent). This may be because: (1) government and government affiliated funds (non-rent-a-union LSVCCs in particular) tend to pursue objectives rather than profit maximization, such as job retention and creation (Hebb and Mackenzie, 2001), and (2) the "large" funds are often sought out as potential syndicate partners by small funds. ${ }^{180}$

Table IV-4 also shows that "large" funds are prone to intra-province investments. ${ }^{181}$ This is consistent with Cumming (2006), who identifies a strong tendency for Canadian private equity investors to finance entrepreneurs who reside in the same province as they do. This also reflects the regional economic development objective often typical of nonrent-a-union LSVCC funds (Hebb and Mackenzie, 2001).

The analyses of the Canadian venture capital industry described in the next chapter (Chapter V) were carried out based on the data described above. Chapter V presents the specific methodologies along with the findings for each of the hypotheses advanced in Chapter III.

${ }^{180}$ For LSVCCs and Provincial VCCs, statutory constraints that restrict their investments to small companies, which typically require a smaller amount of capital, can be another reason to have a large number of portfolio companies (Vaillancourt. 1997: see II-1-2-5). However, specific reasons for institutional investors, such as CDP Capital, maintaining a large number of portfolio companies are not clear. This is beyond the scope of this study but an area for future research.

${ }^{181}$ This is probably for ease of monitoring, controlling, and adding value to the portfolio companies and, in the case of government-affiliated funds, due to statutory constraints (see II-1-2-5 and II-2-2-2). 
Table IV-4: Canadian Funds with Capital under Management Greater than or Equal to \$165 million CDN (as of Dec.2009)

\begin{tabular}{|c|c|c|c|c|c|c|c|}
\hline Fund Name & Type & Mgmt Company & Location & $\begin{array}{l}\text { Cap under } \\
\text { Mgmt (in } \\
\text { millions) }\end{array}$ & \# of PC & $\begin{array}{l}\text { \# of Local } \\
\text { PC }\end{array}$ & $\begin{array}{l}\text { \% of Local } \\
\text { PC }\end{array}$ \\
\hline CDP Capital Private Equity & $\begin{array}{l}\text { Institutional } \\
\text { Investor }\end{array}$ & $\begin{array}{l}\text { CDP Capital Private } \\
\text { Equity }\end{array}$ & $\mathrm{QC}$ & $17,800.00$ & 745 & 504 & $67.65 \%$ \\
\hline Fonds de solidarité (FTQ), National & LSVCC & $\begin{array}{l}\text { Fonds de solidarité } \\
\text { des travailleurs du } \\
\text { Québec (FTQ) }\end{array}$ & QC & $3,702.60$ & 586 & 560 & $95.56 \%$ \\
\hline CDP Capital - Technology Ventures & $\begin{array}{l}\text { Institutional } \\
\text { Investor }\end{array}$ & $\begin{array}{l}\text { CDP Capital Private } \\
\text { Equity }\end{array}$ & $\mathrm{QC}$ & $3,250.00$ & 194 & 109 & $56.19 \%$ \\
\hline CDP Capital - Communications & $\begin{array}{l}\text { Institutional } \\
\text { Investor }\end{array}$ & $\begin{array}{l}\text { CDP Capital Private } \\
\text { Equity }\end{array}$ & $\mathrm{QC}$ & $1,477.00$ & 96 & 47 & $48.96 \%$ \\
\hline BDC Venture Capital Group & Government & $\begin{array}{l}\text { Business } \\
\text { Development Bank of } \\
\text { Canada (BDC) }\end{array}$ & $\mathrm{QC}$ & 840.00 & 395 & 137 & $34.68 \%$ \\
\hline Capital regional et cooperatif & $\begin{array}{l}\text { Provincial } \\
\text { VCC }\end{array}$ & $\begin{array}{l}\text { Desjardins Capital de } \\
\text { risque }\end{array}$ & QC & 722.96 & 288 & 286 & $99.31 \%$ \\
\hline Manulife Capital & $\begin{array}{l}\text { Institutional } \\
\text { Investor }\end{array}$ & Manulife Capital & ON & 470.00 & 34 & 20 & $58.82 \%$ \\
\hline FondAction & LSVCC & FondAction & $\mathrm{QC}$ & 436.88 & 161 & 161 & $100.00 \%$ \\
\hline GrowthWorks Canadian Fund Inc. & LSVCC & $\begin{array}{l}\text { GrowthWorks Capital } \\
\text { Ltd. }\end{array}$ & $\mathrm{BC}$ & 416.79 & 258 & 189 & $73.26 \%$ \\
\hline ARC Energy Venture Fund 4 & $\begin{array}{l}\text { Private } \\
\text { Independent }\end{array}$ & $\begin{array}{l}\text { ARC Financial } \\
\text { Corporation }\end{array}$ & $\mathrm{AB}$ & 403.00 & 5 & 3 & $60.00 \%$ \\
\hline $\begin{array}{l}\text { Celtic House Venture Partners Fund } \\
\text { II }\end{array}$ & $\begin{array}{l}\text { Private } \\
\text { Independent }\end{array}$ & $\begin{array}{l}\text { Celtic House Venture } \\
\text { Partners }\end{array}$ & ON & 375.00 & 21 & 12 & $57.14 \%$ \\
\hline Innovatech du Grand Montreal & Government & Multiple Capital Inc. & $\mathrm{QC}$ & 350.00 & 219 & 205 & $93.61 \%$ \\
\hline Multiple Capital & $\begin{array}{l}\text { Private } \\
\text { Independent }\end{array}$ & Multiple Capital Inc. & $\mathrm{QC}$ & 350.00 & 8 & 7 & $87.50 \%$ \\
\hline RFG Private Equity LP No.1 & $\begin{array}{l}\text { Private } \\
\text { Independent }\end{array}$ & Richardson Capital & MB & 325.00 & 7 & 0 & $0.00 \%$ \\
\hline
\end{tabular}




\begin{tabular}{|c|c|c|c|c|c|c|c|}
\hline ARC Energy Venture Fund 3 & $\begin{array}{l}\text { Private } \\
\text { Independent }\end{array}$ & $\begin{array}{l}\text { ARC Financial } \\
\text { Corporation }\end{array}$ & $\overline{\mathrm{AB}}$ & 310.00 & 2 & 2 & $100.00 \%$ \\
\hline Victoria Park Capital & Government & Victoria Park Capital & SK & 300.00 & 92 & 81 & $88.04 \%$ \\
\hline Clairvest Equity Partners III L.P. & $\begin{array}{l}\text { Private } \\
\text { Independent }\end{array}$ & Clairvest Group Inc. & ON & 300.00 & 8 & 1 & $12.50 \%$ \\
\hline RoyNat Capital Inc. & $\begin{array}{l}\text { Corporate } \\
\text { Financial }\end{array}$ & Roynat Capital Inc. & ON & 298.00 & 294 & 154 & $52.38 \%$ \\
\hline VenGrowth Investment Fund II & LSVCC & $\begin{array}{l}\text { VenGrowth Private } \\
\text { Equity Partners Inc. }\end{array}$ & $\mathrm{ON}$ & 285.95 & 78 & 72 & $92.31 \%$ \\
\hline Working Opportunity Fund & LSVCC & $\begin{array}{l}\text { GrowthWorks Capital } \\
\text { Ltd. }\end{array}$ & $\mathrm{BC}$ & 281.24 & 124 & 120 & $96.77 \%$ \\
\hline $\begin{array}{l}\text { Celtic House Venture Partners Fund } \\
\text { III }\end{array}$ & $\begin{array}{l}\text { Private } \\
\text { Independent }\end{array}$ & $\begin{array}{l}\text { Celtic House Venture } \\
\text { Partners }\end{array}$ & $\mathrm{ON}$ & 280.00 & 19 & 11 & $57.89 \%$ \\
\hline Ventures West 8 & $\begin{array}{l}\text { Private } \\
\text { Independent }\end{array}$ & $\begin{array}{l}\text { Ventures West } \\
\text { Management Inc. }\end{array}$ & $\mathrm{BC}$ & 250.00 & 31 & 9 & $29.03 \%$ \\
\hline HSBC Capital Canada & $\begin{array}{l}\text { Corporate } \\
\text { Financial }\end{array}$ & $\begin{array}{l}\text { HSBC Capital } \\
\text { (Canada) Inc. }\end{array}$ & BC & 247.80 & 4 & 1 & $25.00 \%$ \\
\hline Ventures West 7 & $\begin{array}{l}\text { Private } \\
\text { Independent }\end{array}$ & $\begin{array}{l}\text { Ventures West } \\
\text { Management Inc. }\end{array}$ & $\mathrm{BC}$ & 235.00 & 33 & 17 & $51.52 \%$ \\
\hline Fonds de solidarité (FTQ), Regional & LSVCC & $\begin{array}{l}\text { Fonds de solidarité } \\
\text { des travailleurs du } \\
\text { Québec (FTQ) }\end{array}$ & QC & 217.80 & 587 & 575 & $97.96 \%$ \\
\hline $\begin{array}{l}\text { VenGrowth Advanced Life Sciences } \\
\text { Fund }\end{array}$ & LSVCC & $\begin{array}{l}\text { VenGrowth Private } \\
\text { Equity Partners Inc. }\end{array}$ & ON & 213.73 & 18 & 14 & $77.78 \%$ \\
\hline Novacap II, LP & $\begin{array}{l}\text { Private } \\
\text { Independent }\end{array}$ & $\begin{array}{l}\text { Novacap Investments } \\
\text { Inc. }\end{array}$ & QC & 210.00 & 22 & 18 & $81.82 \%$ \\
\hline Summerhill Ventures I LP & $\begin{array}{l}\text { Private } \\
\text { Independent }\end{array}$ & $\begin{array}{l}\text { Summerhill Venture } \\
\text { Partners }\end{array}$ & ON & 175.00 & 15 & 1 & $6.67 \%$ \\
\hline EDC Equity Fund & Government & $\begin{array}{l}\text { Export Development } \\
\text { Canada }\end{array}$ & ON & 170.00 & 14 & 8 & $57.14 \%$ \\
\hline
\end{tabular}
province in which the fund is located) count all the investments the fund made, including Mezzanine and Buyout financing. 
Table IV-5: Data Available via VCReporter Data Tables

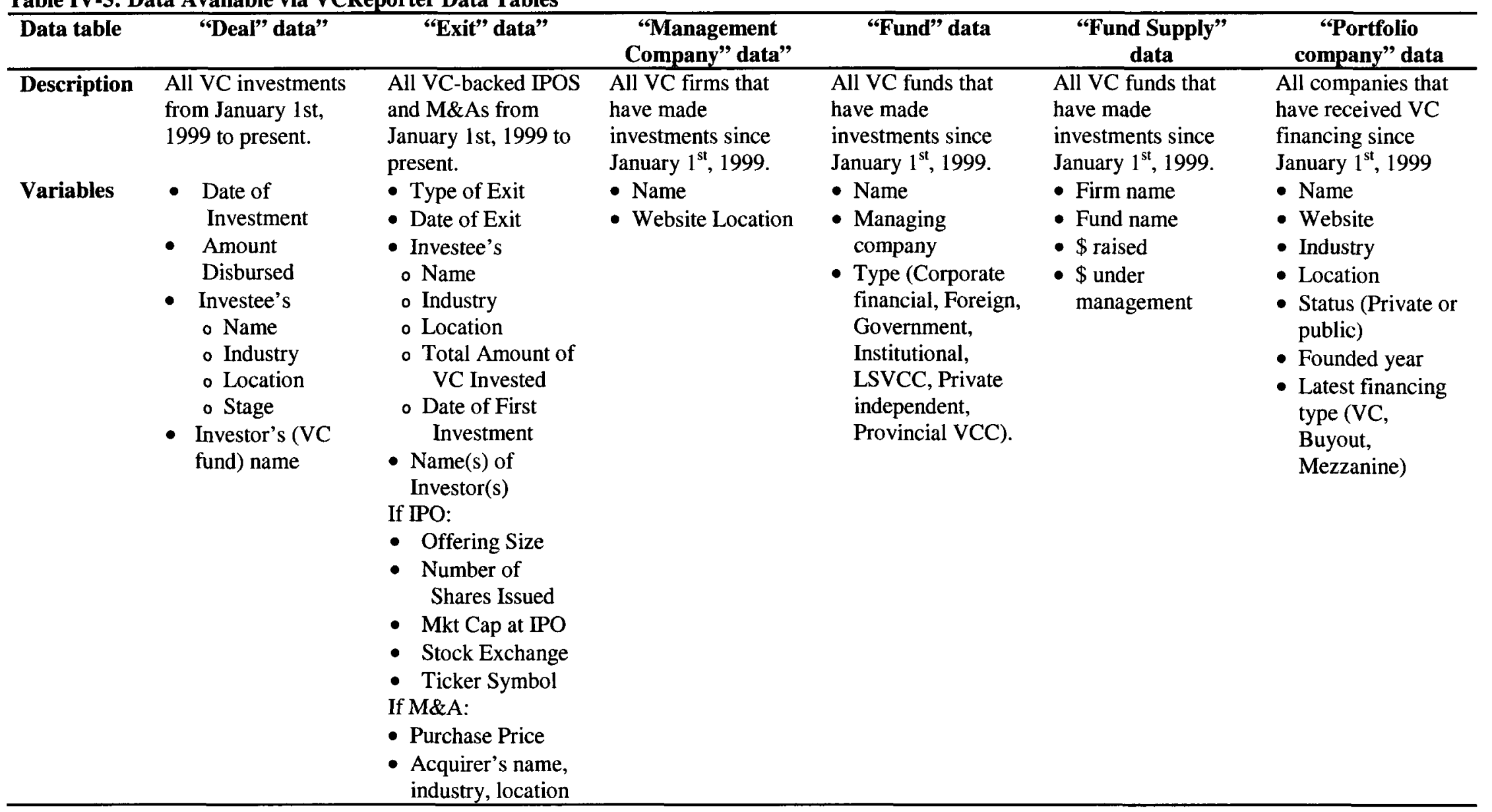


Table IV-6: Variables Available via VCReporter Keyword Search Facility

\begin{tabular}{l} 
VC firm \\
\hline - Year founded \\
- Location \\
- Website \\
- Names of executive officers \\
- Names of managing funds \\
- Breakdown of portfolio companies by sector, \\
location, stage, type (VC)
\end{tabular}

- Fund type

- Management company

- Year founded

- Capital under management

- Preferred investment size (for some funds)

- Investment preference (market (VC), sector, region, stage)

- Breakdown of portfolio companies by sector, location, stage, financing type (VC)

- Number of IPOs and M\&As
Portfolio company

- Year founded

- Status (private or public)

- Location

- Website

- Sector

- VC financing history

- Names of executive officers

- Number of exit 
Table IV-7: Variables Available via VCReporter Database Analyses for Syndication

\begin{tabular}{|c|c|}
\hline Deal & $\begin{array}{l}\text { Date of investment } \\
\text { - Amount disbursed }\end{array}$ \\
\hline Investee firm & $\begin{array}{l}\text { - Name } \\
\text { - Industry } \\
\text { - Location } \\
\text { - Stage } \\
\text { - Website } \\
\text { - Founded year } \\
\text { - Names of executive officers (Keyword search) }\end{array}$ \\
\hline VC firm & $\begin{array}{l}\text { - Name } \\
\text { - Location } \\
\text { - Year founded (Keyword search) } \\
\text { - Investment focus by geography, industry, stage( Keyword search) } \\
\text { - Names of executive officers (Keyword search) } \\
\text { - Names of managing funds (Keyword search) } \\
\text { - Breakdown of portfolio companies by sector, location, stage, type (VC) (Keyword } \\
\text { search)Number of exits (Keyword search) }\end{array}$ \\
\hline \multirow[t]{2}{*}{ VC fund } & $\begin{array}{l}\text { - Name } \\
\text { - Managing company } \\
\text { - Type } \\
\text { - \$ raised } \\
\text { - } \text { S under management } \\
\text { - Year founded (Keyword search) } \\
\text { - Investment preference by market (VC), sector, region, stage (Keyword search) } \\
\text { - Breakdown of portfolio companies by sector, location, stage, financing type (VC) } \\
\text { - } \text { (Keyword search) } \\
\text { - Number investment size (for some funds) (Keyword search) } \\
\end{array}$ \\
\hline & Analyses for Exit \\
\hline Deal & $\begin{array}{l}\text { - Type of Exit (IPO or M\&A) } \\
\text { - Date of Exit }\end{array}$ \\
\hline Investee & $\begin{array}{l}\text { - Name, Industry, Location, Website } \\
\text { - Founded year } \\
\text { - Total amount of Venture capital invested } \\
\text { - Date of first investment } \\
\text { - VC financing history (Keyword search) } \\
\text { - Executive officers (Keyword search) }\end{array}$ \\
\hline VC fund & $\begin{array}{l}\text { - Name } \\
\text { - Managing company } \\
\text { - Type (Corporate financial, Foreign, Government, Institutional, LSVCC, Private } \\
\text { independent, Provincial VCC). } \\
\text { - \$ raised } \\
\text { - \$ under management } \\
\text { - Year founded (Keyword search) } \\
\text { - Preferred investment size (for some funds) (Keyword search) }\end{array}$ \\
\hline
\end{tabular}


- Investment preference by(market (VC), sector, region, stage (Keyword search)

- Breakdown of portfolio companies by sector, location, stage, financing type (VC) (Keyword search)

VC firm - Name, Website, Location

- Year founded (Keyword search)

- Names of executive officers (Keyword search)

- Names of managing funds (Keyword search)

- Investment focus by(sector, location, stage (Keyword search)

- Breakdown of portfolio companies by sector, location, stage, type (VC) (Keyword search)

- Number of exit (Keyword search)

If IPO: - Offering size

- Number of shares issued

- Market cap at IPO

- Stock exchange

- Ticker symbol

If M\&A: - Purchase price

- Acquirer's name, industry, location 


\section{EMPIRICAL ANALYSES AND FINDINGS}

This chapter describes the analytical techniques employed to test the various hypotheses advanced in Chapter III and presents the associated empirical findings. The first section presents the findings with respect to syndication practice (Hypotheses 1 5); the second section shows findings regarding exit patterns (Hypotheses 6 11); and, the third describes a range of robustness checks. A particular challenge of this study is to gauge the size of a syndicate; accordingly, the third section discusses the difficulties associated with the measurement of the syndicate size; the rationales behind the measures of syndicate size used in this study; and, the various alternative approaches employed to check the robustness of the results presented in the first two sections.

\section{Results: Syndication Practice}

\section{1-1. Hypothesis 1}

\section{1-1-1. Analysis of the Canadian Data}

The following is the first hypothesis that was tested.

Hypothesis 1: Smaller venture capital funds are more likely to be capital constrained (that is, to have smaller amounts of capital available for each of its portfolio companies). 
The amount of capital a venture capital fund has available for a given investment is usually unobservable to outsiders. While data on fund size, the number of deals and deal sizes are observable, the amounts of individual funds' investments in syndicated deals are not normally reported. Moreover, a venture capital fund's capital availability should ideally be considered from a number of perspectives, including the fund's current, as well as its future, planned portfolio composition, its risk-reward posture, its current status and future fundraising plans. However, the availability of data restricts this. Accordingly, testing Hypothesis 1 required a proxy measure. This is not unusual in the literature on financial constraints. ${ }^{182}$ Accordingly, a venture capital fund's capital availability was measured in the following four alternative ways:

1. The difference between capital under management of the fund and capital already disbursed (Cap-CC[\$Dis]). Capital committed was estimated as the sum of [the total amount disbursed in a particular (usually syndicated) investment round divided by the number of investors] for all financing rounds in which the fund participated. That is:

\footnotetext{
${ }^{182}$ Previous studies of capital constraints have used a variety of proxies to measure the degree of financial constraints. For example, Fazzari, Hubbard, and Peterson (1988), Hoshi, Kashyap, and Scharfstein (1991), Oliner and Rudebusch (1992), Carpenter, Fazzari, and Peterson (1994), and Schaller (1993) used the sensitivity of investment to cash flow as a measure of liquidity constraints faced by publicly traded companies. Evans and Jovanovic (1989), Bernhardt (1994) and Blanchflower and Oswald (1998), Black, de Meza, and Jeffreys (1996), and Holtz-Eakin, Julfaian, and Rosen (1994a, 1994b) used the entrepreneur's personal assets (i.e., the smaller the assets, the more financially constrained the firm). Guiso (1998) used the likelihood of the rejection of a loan application. Binks and Ennew (1996) and Westhead and Storey (1997) used an indicator variable derived from business managers' perceived (reported) financial constraints.
} 


$$
\begin{aligned}
& (\text { Cap }-C C[\$ D i s])= \\
& \text { Capital under Management - } \\
& \sum \frac{\text { Amounts Invested by syndicates }}{\# \text { of Investors in syndicates }}
\end{aligned}
$$

2. An alternative measure of capital under management of the fund less capital already committed was also employed (Cap-CC[\$Ave]). Here, financing rounds were classified by sector, stage, location, year and the number of investors, and the average of the amounts invested was calculated for each of those combinations. Capital already committed was proxied by the sum of [the average size of the investments corresponding to the characteristics of the financing round in which a fund participated divided by the number of investors in each round] for all financing rounds in which the fund participated. That is:

$$
\begin{aligned}
&(\text { Cap }-C C[\$ A v e]) \\
&=\text { Capital under Management } \\
&-\sum \frac{\text { Average Amount Invested }}{\# \text { of Investors }}
\end{aligned}
$$

3. A third measure was simply the number of companies in the fund's portfolio (\#PC).

4. The final alternative measure was the average of [the amount disbursed divided by the number of investors] for all the financing rounds in which the fund participated (Ave\$Dis). 
The four measures of capital availability above were estimated at the point in time when the fund was three years old (three years after its founding). While somewhat arbitrary, it was necessary to select a standard fund age, since capital availability might appear greater for funds at earlier stages of existence simply because they have just been founded and thus have made few investments. The three-year mark was selected as Gompers (1996a) reports that funds typically invest all their capital within the first five years and harvest investments during the last five. ${ }^{183}$

The first measure used the actual dollar amount invested to estimate a fund's capital availability. This may have limited the measure's ability to show the capital shortage problems the fund may have been facing because the amounts invested could be smaller when a fund has limited financial recourse. The second measure addressed this point by taking the average amount invested for counterpart rounds rather than the actual amount invested.

The first and second measures were closer to the ideal - but unobservable - capital availability measure in the sense that they estimated what was left over after the fund had allocated capital during its first three years. A limitation of these measures is that they include the amount of capital under management of a fund, with which those measures are then compared. Thus, even if a significant relation between those two measures and size (capital under management) had been found, it would not have been perfectly clear if the significance represented the fact that the amount of capital a fund manages affected

\footnotetext{
${ }^{183}$ In the case of private independent limited partnerships.
} 
the fund's financial availability, or whether it was simply an artefact of two variables sharing the same value. To address this point, the third and fourth measures, which do not have capital under management as a component, were employed.

Table V-1 shows the estimated correlation coefficient between fund size (measured as the natural $\log$ of capital under management of the fund) and each of the four measures of capital availability. For the entire sample, all four measures of capital availability were positively correlated with size at a one percent p-value, suggesting larger funds have more capital available than smaller funds. The fact that both the number of companies in the fund's portfolio (\#PC) and the average amount disbursed by the fund (Ave\$Dis) were significantly correlated with size indicates that large size allows a venture capital fund not only to invest in a larger number of entrepreneurial firms but also to invest a larger amount of capital in those companies.

A significant correlation between size and each of the four capital availability measures was confirmed by alternative analytical approaches (ANOVA, OLS, and Poisson regression), the results of which are displayed in Appendix III. For ANOVA, funds were classified in quartiles based on their size, and the average value of each of the four capital availability measures for each size quartile for the entire sample were compared. For the OLS models, each of the three constraint measures (Cap-CC[\$Dis], Cap-CC[\$Ave], and Ave\$Dis) were used, alternatively, as dependent variables, with independent variables comprising dummy variables corresponding to fund size categories, and control variables 
reflecting type of fund and fund location. The Poisson model regressed the number of portfolio companies against fund size along with control variables.

Table V-1: Estimated Correlation Coefficient between Size of Fund and Measures of Capital Availability

\begin{tabular}{llllll}
\hline & Capital Availability & \#PC & $\begin{array}{l}\text { Cap- } \\
\text { CC[\$Dis] }\end{array}$ & $\begin{array}{l}\text { Cap- } \\
\text { CC[\$Ave }]\end{array}$ & Ave\$Dis \\
\hline $\ln ($ Size) & Entire Sample (N=91) & $.303^{* * *}$ & $.454^{* * *}$ & $.460^{* * *}$ & $.320^{* * *}$ \\
$\ln ($ Size) & Private Independent Only $(\mathrm{N}=65)$ & .191 & $.437^{* * *}$ & $.443^{* * *}$ & $.437^{* * *}$ \\
\hline
\end{tabular}

When the subset of private independent funds was examined, similar results were obtained with one exception. While three measures of capital availability (Cap-CC[\$Dis], Cap-CC[\$Ave], Ave\$Dis) remained significantly and positively correlated with size, the number of portfolio companies (\#PC) was not correlated with size to a statistically significant extent. The insignificance of \#PC, along with the significant positive correlation between Ave\$Dis and size, demonstrates that Canadian private independent

${ }^{184} \mathrm{~A}$ factor analysis identified two components into which the four measures of capital constraint can be categorized: the first group consists of Cap-CC[\$Dis] and Cap-CC[\$Ave]; the second consists of Ave\$Dis and \#PC (see Table V-2 below). This is not surprising as all measures in the first group uses capital under management and those in the second group do not. Ave\$Dis and \#PC were negatively correlated since the amount invested is likely to decrease as the number of companies in the fund's portfolio increases.

Table V-2: Rotated (Varimax) Component Matrix of Capital Availability Measures

\begin{tabular}{lrr}
\hline & Component 1 & Component 2 \\
\hline Cap-CC[\$Dis] & 0.996 & 0.084 \\
Cap-CC[\$Ave] & 0.995 & 0.096 \\
Ave\$Dis & 0.034 & 0.773 \\
\#PC & -0.100 & -0.688 \\
\hline
\end{tabular}

${ }^{185}$ The correlation coefficient estimations, as well as the ANOVA tests, were also attempted by employing natural-log transformed values of capital availability. The results were similar to those with raw values, except for the variable Ave(\$Dis) (insignificant with log transformation and significant without). However, the normal Q-Q plot exhibited closer normality when not transformed to natural $\log$, suggesting that the results with raw valuables are more consistent. 
funds appear to increase the amounts they invest, rather than increase the number of entrepreneurial firms in their portfolios, when they raise a greater amount of capital. The corollary is that small funds may be inclined to make small (possibly insufficient) amounts of investments in a relatively higher number of entrepreneurial firms rather than large amounts of investments in a few entrepreneurial firms; this is, probably, for the purpose of diversification. This finding, therefore: (1) supports the presence of a minimum number of portfolio companies a venture capital fund must have in its portfolio in order to maintain a reasonable level of diversification, as suggested by Murray (2007), Laine and Torstila (2003), Huntsman and Hoban (1980), among others; ${ }^{186}$ and, (2) suggests that Canadian entrepreneurial firms may not be receiving venture capital financing sufficient for their growth when backed by small funds.

The significance of \#PC for the entire sample and its insignificance for private independent funds may reflect the differences in objectives and statutory covenants between private independent and non-private independent funds. The latter are less concerned with profit maximization (Siegel, Siegel, and Macmillan, 1988; Wang, Wang, and Lu, 2002; see II-1-2-3). ${ }^{187}$ In particular, government-affiliated funds, such as

\footnotetext{
${ }^{186}$ This result is also consistent with Elango, Fried, Hisrich, and Polonchek (1995), who report that the maximum acceptable size of an investment is seven times greater for large funds than it is for small funds (\$9.7 versus $\$ 1.4$ million US).

187 For example, Cumming and MacIntosh (2002) argued that governments are more concerned with strengthening the entrepreneurial sector than with profit maximizations.
} 
LSVCCs, are more likely to have objectives additional to profit maximization and to be restricted to investments in smaller entrepreneurial firms (see II-1-2-5). ${ }^{188}$

\section{1-1-2. Comparisons with the United States ${ }^{189}$}

So far, this research has investigated the Canadian case and obtained findings consistent with the hypothesis that, compared to large funds, small funds are relatively more likely to be capital constrained. This section reports on a comparison of capital availability between Canadian and American venture capital funds.

Figure V-1 compares the average number of companies in venture capital fund portfolios across different size categories in Canada and the United States. ${ }^{190}$ It shows that the number of portfolio companies increases with size in both countries, a result consistent with Hypothesis 1. A larger amount of capital under management means more capital available, allowing the fund to allocate financial resources to a larger number of

\footnotetext{
${ }^{188}$ Detailed Consideration of how funds` objectives and covenants are related to the portfolio structure and increases in the number of portfolio companies for non-private independent funds is beyond the scope of this study; however, it is an interesting area for future research.

${ }^{189}$ As discussed in Chapter IV, the analyses in this dissertation use the data extracted from the Thomson Financial VCReporter database described previously. However, as the Thomson database does not provide information on American venture capital funds, the comparison between the Canadian and the American cases performed here uses data drawn from the Venture Economics SDC Platform. The number of funds used for this comparison is therefore different from the number of funds used in the analysis of the Canadian data (extracted from Thomson). The data from SDC provides fewer variables, making it impossible to analyze the American case in the same way as the Canadian case. In the comparison performed here, the number of portfolio companies is the only variable available to explore Hypothesis 1 .

${ }^{190}$ Because fund founded year and past capital under management are not available in the data from SDC, the number of portfolio companies and the size are based on the data dating back to December 2009 for all funds. This means that the fund age is not constant across funds (as it was in the Canadian analysis described in the previous section).
} 
entrepreneurial firms. The correlation coefficient between natural log transformation of size (capital under management) and number of portfolio companies was .364 for Canada and .310 for the United States; both of which are significant (p-value $=0.000$ for both). ANOVA also revealed significant $(p-v a l u e=0.000)$ differences in the number of portfolio companies across different size categories for both samples. ${ }^{191}$

Figure V-1: Average Number of Portfolio Companies by Size Categories; All Fund

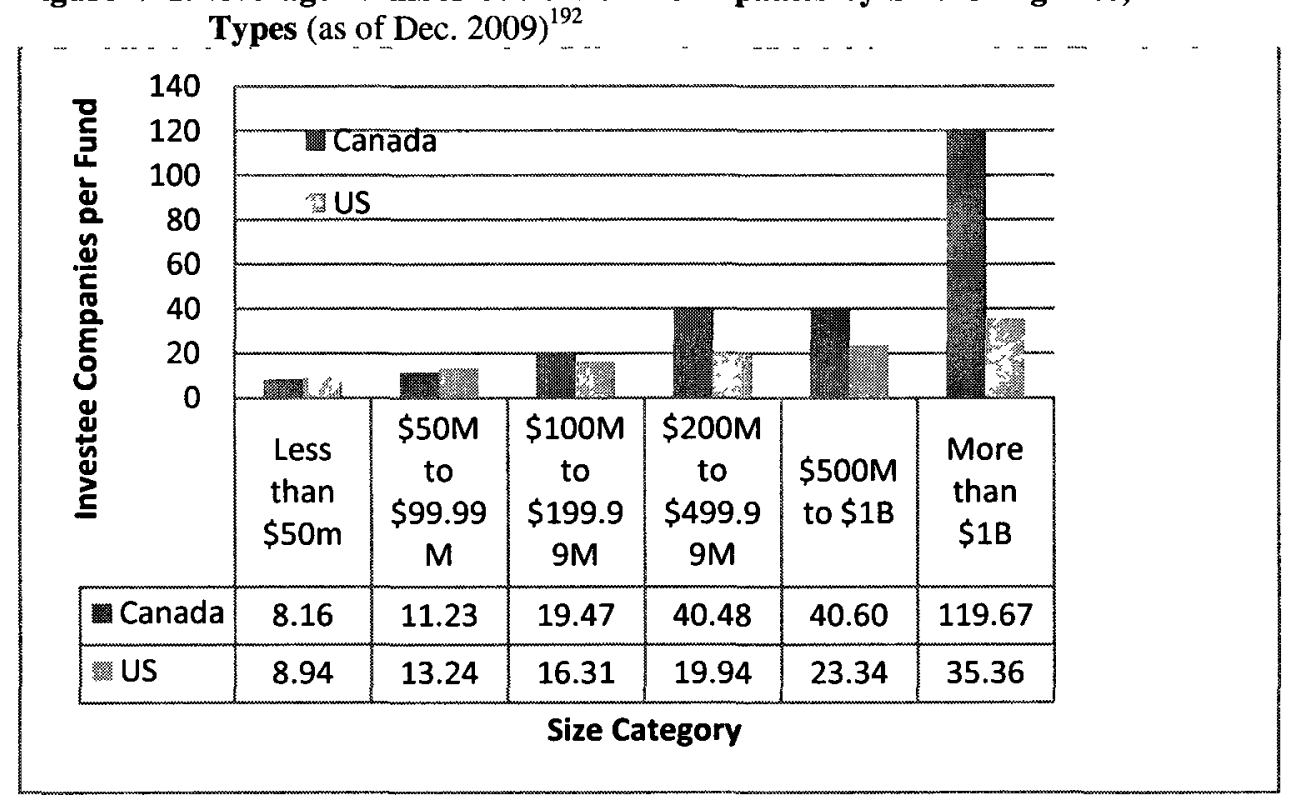

Although both samples support the view that smaller venture capital funds are more likely to be capital constrained, the difference between the two is striking. The number of companies in the portfolio increases with size much more rapidly in Canada than in the United States. For the category of capital under management of more than one billion

\footnotetext{
${ }^{191}$ For the sake of brevity, the results of ANOVA and the post-hoc t-tests are not included here but are available upon request. The correlation coefficient estimations, as well as the ANOVA tests, were also attempted with the natural log transformation of the number of portfolio companies. The results were the same.

${ }^{192}$ US dollars were converted to Canadian dollars using the Bank of Canada nominal exchange rate as of December $31^{\text {st }}, 2009$.
} 
dollars, the average number of portfolio companies is 3.4 times larger for Canadian funds than it is for American funds.

Table V-3 presents the Poisson regression estimate of the number of portfolio companies. The coefficient for the interaction term between the country (US) dummy and size was significantly larger for Canada than it was for the United States (t-value=33.315, pvalue $=0.000$ ). This further supports the above observation: the number of portfolio companies increases with size more rapidly in Canada.

Table V-3: Poisson Regression on Number of Portfolio Companies

\begin{tabular}{|c|c|c|c|c|}
\hline & $\overline{\mathbf{B}}$ & S.E. & Wald Chi-Square & Sig. \\
\hline Intercept & 2.624 & 0.004 & 421279.895 & 0.000 \\
\hline Canada*size & 1.374 & 0.033 & 1784.764 & 0.000 \\
\hline US*size & 0.285 & 0.004 & 6619.541 & 0.000 \\
\hline US dummy & -0.038 & 0.020 & 3.513 & 0.061 \\
\hline Goodness of fit measures & Value & df & Value/df & \\
\hline Deviance & 69522 & 4707 & 14.8 & \\
\hline Scaled Deviance & 69522 & 4707 & & \\
\hline Pearson Chi-Square & 104580 & 4707 & 22.2 & \\
\hline Scaled Pearson Chi-Square & 104580 & 4707 & & \\
\hline Likelihood Ratio Chi-Square & 4754 & 3 & & 0.000 \\
\hline
\end{tabular}

* The dependent variable was the number of portfolio companies of a fund.

* US dummy takes the value 1.0 if the deal was made in the United States, 0.0 in Canada.

* Canada*size and US*size are the interaction terms between the country (US) dummy and the size of the fund.

This result begs the question as to why Canadian venture capital funds, especially large funds, spread their capital among so many entrepreneurial firms. One possible reason is that, in Canada, the majority of large funds are not private independent funds. As discussed, non-private independent funds are typically less concerned with profit 
maximization. Moreover, government direct investors (for example, BDC and EDC) and government-affiliated funds may have statutory remits that limit their investments to small companies, which are likely to require relatively small amounts of capital. To address this point, the above analysis was repeated for the private independent funds with the results shown in Figure V-2.

Figure V-2: Average Number of Portfolio Companies by Size Categories; Private Independent Funds (as of Dec 2009)

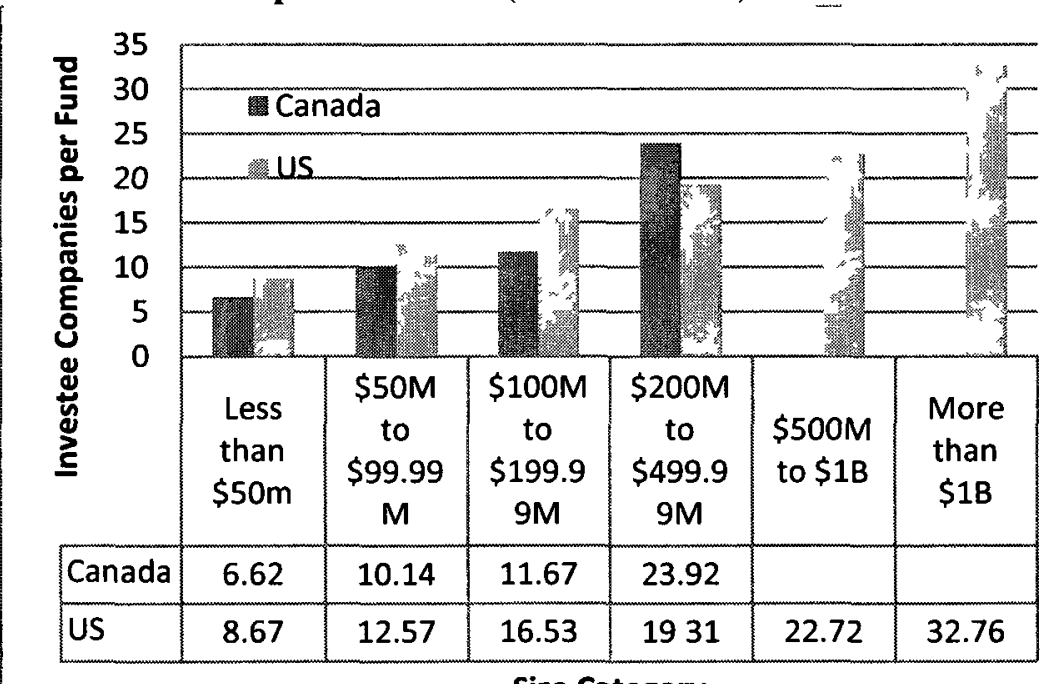

Size Category

There is only one private independent fund that manages capital greater than $\$ 500$ million in Canada. ${ }^{193}$ For the $\$ 200$-to- $\$ 500$ million size category, the discrepancy in the average number of portfolio companies between Canadian and American funds shrinks, and for smaller size categories, the average number of portfolio companies turns out to be

\footnotetext{
${ }^{193}$ The only private independent fund with a size more than $\$ 500$ million, RFG Private Equity L P. II, was omitted from the analysis of the average portfolio companies for six size categories of private independent funds (shown in Figure V-2, because the average of one fund is likely to cause a biased result (in fact, RFG Private Equity L.P. II has capital under management of $\$ 720$ million, yet has invested in only one company as of Dec 2009).
} 
larger for American funds than for Canadian funds. Therefore, it appears that Canadian large funds that have many entrepreneurial firms in their portfolios are non-private independent. ${ }^{194}$

In Canada, large funds are rare and small funds need (preferably large) syndicate partners in order to provide sufficient amounts of capital to their investee firms. Therefore, the relatively few large Canadian funds are, arguably, frequently sought-after as syndicate partners and make syndicated investments with many different small funds, thereby increasing the number of companies in their portfolios while complying with their small investment mandates. To address this point further, the distribution of funds by fund size was investigated.

Figure V-3 shows that the Canadian venture capital industry is comprised of more small funds and fewer large funds than the American industry. In Canada, per 100 small funds, only 7.8 large funds are available as potential syndicate partners. In contrast, in the United States, 22.2 large funds are available as potential syndicate partners per 100 small

194 The number of portfolio companies was significantly correlated with size for the United States (correlation coefficient $=0.338$, p-value $=0.000$, significance for the ANOVA test $=0.000$ ). It was significant also for Canada (correlation coefficient $=0.388, \mathrm{p}$-value $=0.000$, significance for the ANOVA test $=0.000$ ). This is inconsistent with the result of the Canadian analysis using the data from the Thomson database reported in the previous sub-subsection: the correlation between the number of portfolio companies and size was not significant. This discrepancy is probably due to the fact that in the Canadian analysis with the Thomson data the correlation was examined at the point when the fund was three years old while in this US-Canada comparison using the SDC data, it was investigated as of Dec. 2009 (in fact, the correlation was significant for Canadian funds using the Thomson data when the "as of Dec. 2009" cutoff point was used). The analysis with a fixed age appears to be more reliable since the analysis with a variety of ages may have some extreme values for funds at the early stage of their lives (those that have made a small number of investments). However, data constraints do not allow a fixed-age analysis for the US-Canada comparison. The results of correlation coefficient estimates, ANOVA and post-hoc t-tests for private independent funds obtained here are available upon request. 
funds. The structural difference between the two industries is more dramatic when only private independent partnerships are taken into account (Figure V-4).

Figure V-3: Distribution of VC Funds by Size; All Fund Types (as of Dec. 2009)

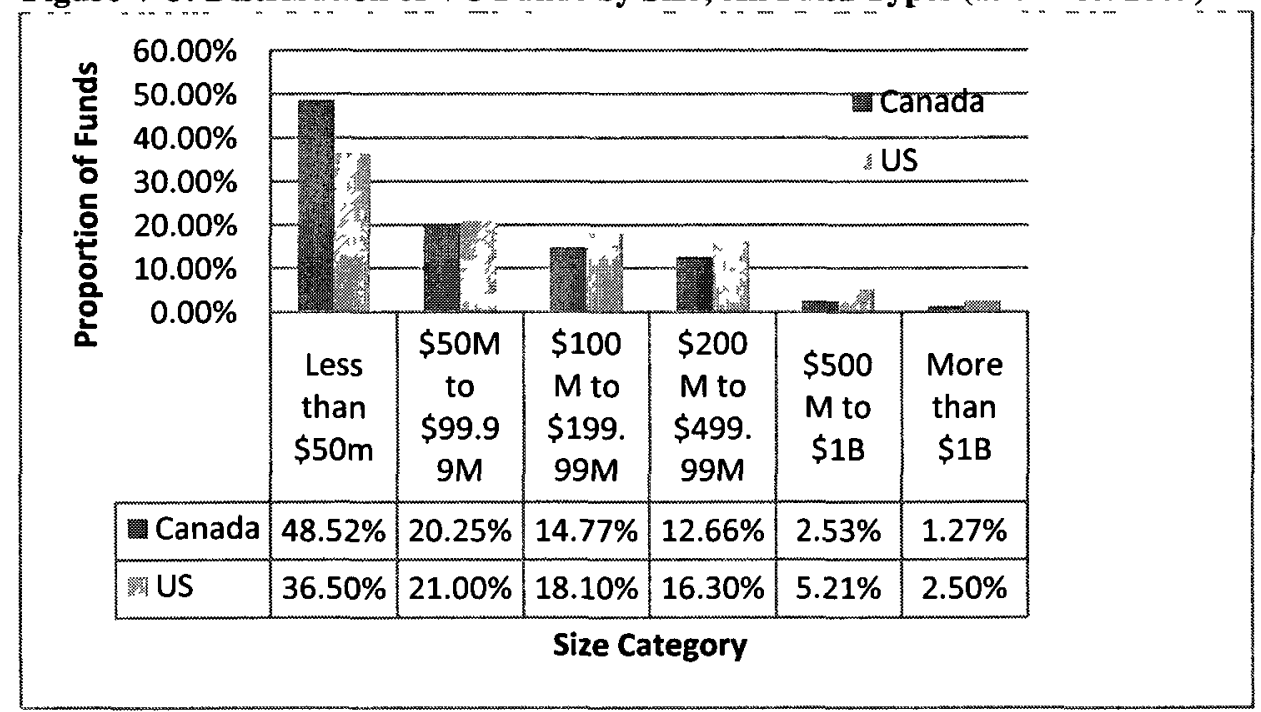

Figure V-4: Distribution of VC Funds by Size; Private Independent Funds (as of Dec. 2009)

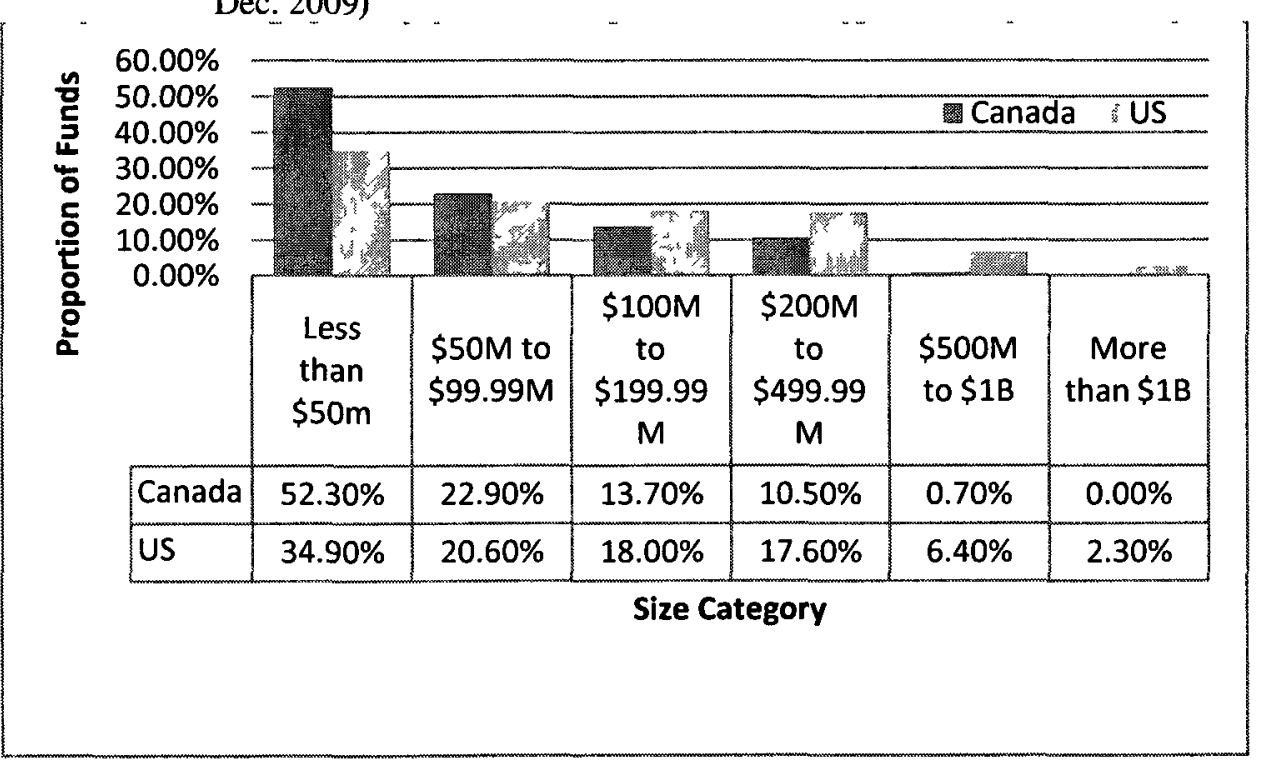


It therefore seems plausible that large Canadian funds have a greater number of portfolio companies not only because they are non-private independent and restricted to small investments but also because they are frequently sought after by smaller funds as syndicate partners (as investee firms grow and require additional capital) due to the relative scarcity of large funds in the industry.

\section{1-1-3. Summary of Results: Hypothesis 1}

The results of testing Hypothesis 1 are summarized as follows:

- For the entire sample, all four capital availability measures were positively and significantly correlated with size. This is consistent with Hypothesis 1 that smaller venture capital funds are more likely to be financially constrained.

- For the sample of private independent funds, three out of four measures of capital availability were positively and significantly correlated with size, again supporting Hypothesis 1. However, one of the four measures, namely that of the number of portfolio companies, was not significantly related with size. This suggests that Canadian private independent partnerships increase the amount they invest per financing round rather than increase the number of entrepreneurial firms in their portfolios. In other words, small funds tend to invest relatively smaller (and possibly insufficient) amounts in relatively more companies rather than invest more capital in a few entrepreneurial firms. This further implies that 
Canadian entrepreneurial firms may not receive sufficient financing to support firm owners' growth aspirations when backed by small funds. This result is also consistent with the idea that a venture capital fund must maintain a minimum number of portfolio companies for diversification purposes, as suggested by Murray (2007) and others.

- The significance of the number of portfolio companies for the entire sample and its insignificance for private independent funds arguably reflects the differences in objectives and statutory covenants between private independent and non-private independent funds (the latter is less concerned with profit maximization (Cumming and MacIntosh, 2002; Siegel, Siegel, and Macmillan, 1988; Wang, Wang, and $\mathrm{Lu}, 2002$ ). In particular, LSVCCs are restricted to investments in entrepreneurial firms of a size smaller than a certain threshold, which increases the number of companies in their portfolios.

- The comparison of the average number of portfolio companies in Canadian and American funds revealed that:

- The number of portfolio companies increases with size for both samples, a result consistent with Hypothesis 1: large funds' greater capital availability allows them to invest in a larger number of entrepreneurial firms thereby diversifying their portfolios.

- The number of companies in the portfolio increases with size much more rapidly in Canada than in the United States. For the category of capital 
under management of more than one billion dollars, the average number of portfolio companies is 3.4 times larger for Canadian funds than it is for American funds. This is probably because:

- Large funds in Canada are not private independent and may be restricted to small investments and be less likely to have objectives of profit maximization; and,

- As investee firms grow, large funds are frequently sought after by smaller funds as syndicate partners.

The relatively high number of entrepreneurial firms that Canadian large funds maintain in their portfolios means that:

- The financial capital of large funds is necessarily spread thinly - it is conceivable that there may be few, if any, funds in Canada with the ability to invest a large sum of capital into an investee company; and,

- The ability of managers of large funds to add non-financial value to their investee companies (see II-1-1-4) is also spread thinly.

The finding of relatively more companies in Canadian large funds' portfolios also prompts a re-consideration of syndication behaviour. This dissertation had hypothesized (at the proposal stage) a high syndication activity for small funds in order to provide sufficient capital to their respective investee companies (especially when the company grows successfully and requires a larger amount of financing). However, the high number of portfolio companies for large funds implies that they are frequently sought after by 
smaller funds as syndicate partners. This suggests a high level of syndication activity not only for small but also for large funds.

\section{1-2. Hypotheses 2 and 3}

Hypothesis 2: Small venture capital funds syndicate more often.

Hypothesis 3: The frequency of syndication is higher for later financing rounds (as investee firms grow).

Hypothesis 2 was tested using the following three distinct approaches:

1. Analysis of syndication ratio (the number of syndicated deals divided by the total number of deals in which a given fund has participated) to determine the extent to which a fund's propensity to syndicate is associated with the size of the fund;

2. Logistic regression analysis to determine the extent to which fund size is associated with the likelihood that first round investments are syndicated;

3. Logistic regression analysis to determine the extent to which fund size influences the likelihood of adding a new investor to an existing syndicate.

Logistic regression analyses were also used to test Hypothesis 3 by adding measures of the investee company's development to the models estimated in 2 and 3 above. These estimations seek to investigate the relationship between growth of investee firm and syndication. 


\section{1-2-1. Syndication Ratio}

Following Hopp and Rieder (2002), the relationship between fund size and frequency of syndication is premised on the calculation of a syndication ratio $\left(\operatorname{SYNRATIO}{ }_{i, t}\right)$ : the ratio of the number of syndicated investments to the total number of investments by fund $i$ at time $t$. The higher the ratio the more often a fund syndicates. Three cut-off points were used for $t$ : the fund at three years old, at five years old, and as of December $31^{\text {st }}, 2009$. The first two cut-off points were employed in order to mitigate the bias caused by extreme values (zero, one, or close to zero/one) of the syndication ratio for funds that had just been founded and thus had made few investments. ${ }^{195}$ The last (as of Dec. 2009) cutoff point was used in order to reduce the number of funds that had not made any investments by the time they were three (or five) years old. Figure V-5 shows the distribution of Canadian venture capital funds by syndication ratio.

\footnotetext{
${ }^{195}$ Gompers (1996a) reports that funds typically invest all their capital in the first five years and harvest
} investments during the last five (in the case of private independent limited partnerships). 


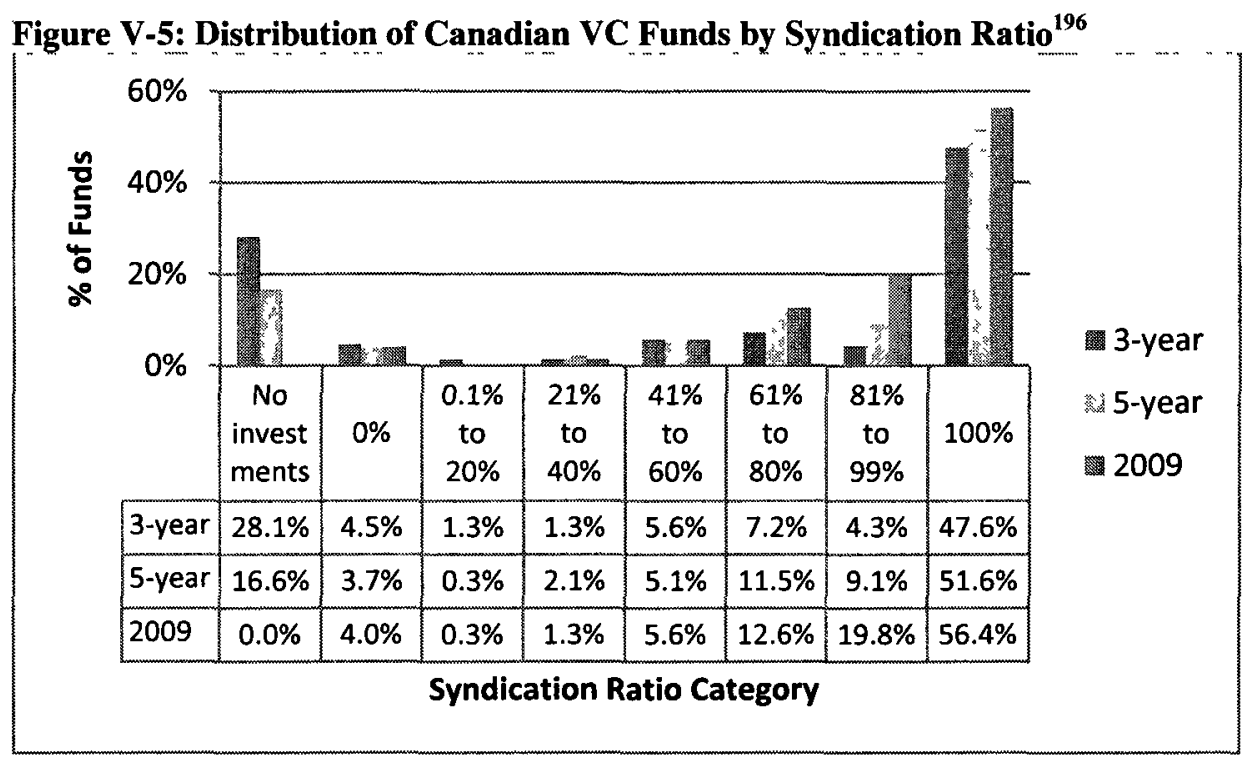

Figure V-5 shows a high level of syndication activity in the Canadian venture capital industry. Three years after founding, 178 of 374 funds (47.6 percent) had a syndication ratio of $100 \%$ (all of their investments were syndicated) and 221 funds (59.1 percent) had a syndication ratio greater than 60 percent. With the five-year cut-off point, 193 out of 374 (51.6 percent) funds had a syndication ratio of $100 \%$ and 270 funds ( 72.2 percent) had a syndication ratio greater than 60 percent. As of December 2009, 211 funds (56.4 percent) had a syndication ratio of $100 \%$ and 332 funds ( 88.8 percent) had a syndication ratio greater than 60 percent. Table V-4 compares the average syndication ratios for Canadian funds with those for German funds in Hopp and Rieder (2006). ${ }^{197}$ A high level of syndication activity is observed in the Canadian venture capital industry. For all types of fund categories, the average syndication ratio was higher for Canada than it was for

\footnotetext{
${ }^{196}$ No investment indicates that the fund did not make any investments prior to the cut-off point. Syndicate ratio of zero means that all the investments the fund made were sole investments.

${ }^{197}$ It would be interesting to compare syndication ratios between Canada and the United States. However, to the author's knowledge, no study has calculated syndication ratios for American funds.
} 
Germany. Canadian private independent funds, for example, had a propensity to syndicate approximately 1.4 times more than did their German counterparts.

Table V-4: Average Syndication Ratios by Type of Funds in Canada and Germany

\begin{tabular}{llcccc}
\hline $\begin{array}{l}\text { Type of } \\
\text { Fund }\end{array}$ & Syn Ratio & $\begin{array}{c}\text { Syn Ratio } \\
(\mathbf{3} \text { yr.) }\end{array}$ & $\begin{array}{c}\text { Syn Ratio } \\
\text { (as of 2009) }\end{array}$ & $\begin{array}{c}\text { Syn Ratio in } \\
\text { Germany* }\end{array}$ \\
\hline Private & Mean & 0.86 & 0.87 & 0.88 & 0.61 \\
Independen & $\mathrm{N}$ & 159 & 177 & 202 & 90 \\
$\mathbf{t}$ & Std. Error. & 0.0219 & 0.0189 & 0.0175 & \\
\hline Corporate & Mean & 0.92 & 0.91 & 0.91 & 0.75 \\
Financial & $\mathrm{N}$ & 13 & 18 & 27 & 26 \\
& Std. Error. & 0.0444 & 0.0362 & 0.0303 & 0.41 \\
\hline Corporate & Mean & 0.80 & 0.85 & 0.88 & 17 \\
Industrial & $\mathrm{N}$ & 23 & 25 & 25 & 0.66 \\
& Std. Error. & 0.0746 & 0.0525 & 0.0466 & 20 \\
\hline Governmen & Mean & 0.70 & 0.73 & 0.80 & \\
t & $\mathrm{N}$ & 18 & 21 & 31 & \\
& Std. Error. & 0.0929 & 0.0759 & 0.0512 & \\
\hline Total & Mean & 0.83 & 0.85 & 0.87 & \\
& $\mathrm{~N}$ & 260 & 303 & 0.05 & \\
& Std. Error. & 0.0183 & 0.0148 & 0.0125 & \\
\hline
\end{tabular}

* Source: Hopp and Rieder (2006).

This level of syndication activity in Canada may be a consequence of the industry structure. The large number of small funds needs syndication partners in order to provide sufficient capital to their investee firms as the firms grow. Thus, a few large funds are sought after by many small funds and, as a result, syndication is frequent.

To explore further potential determinants of syndication frequencies among Canadian venture capital funds, a logistic regression framework was employed using a venture capital fund as the unit of analysis. ${ }^{198}$ The dependent variable was assigned a value of one

${ }^{198}$ The initial plan was to estimate an OLS regression model with syndication ratio as a dependent variable. However, syndication was so frequent in Canada that the originally proposed methodology was not applicable. 
if a fund had a syndication ratio of more than 50 percent, and zero if the syndication ratio was less than or equal to 50 percent. The analysis tests whether the odds ratio of having a syndication ratio greater than 50 percent is higher for funds managing a smaller amount of capital, as per Hypothesis 2. The model is:

$$
\operatorname{logit}\left[\pi\left(S R_{i, t}\right)\right]=\alpha_{0}+\alpha_{1} * S I Z E_{i}+\tilde{\alpha}_{2} * V \tilde{C} \text { charac }_{i}+\varepsilon_{i}
$$

where: $\operatorname{logit}\left[\pi\left(S R_{i, I}\right)\right]=\log \left(\frac{\pi\left(S R_{i, t}\right)}{1-\pi\left(S R_{i, t}\right)}\right)$, where $\pi\left(S R_{i, I}\right)=$ probability for fund $i$ to have $\begin{array}{ll}S I Z E_{i}= & \begin{array}{l}\text { a syndication ratio greater than } 50 \text { percent at time } t . \\ \text { Capital under management of venture capital fund } i .\end{array} \\ V \tilde{C} \text { charac }_{i}=\quad \begin{array}{l}\text { A vector of variables controlling for the characteristics of } \\ \text { venture capital fund } i .\end{array}\end{array}$ The control variables included in the model are: type of fund, location of the fund, and level of experience of the management company of the fund. See Appendix I for a detailed discussion of the control variables used in the analyses of syndication in this study.

The results of the estimation of the logistic regression are presented in Table V-5. ${ }^{200}$ According to Table V-5, no independent variable was found to be significantly associated

\footnotetext{
${ }^{199}$ The size of the fund was measured by the amount of capital under management for the individual fund. Sorenson (2007) argues that the size of the individual fund is a better measure of the capital available for an investment in a company (as compared to the size of the fund management company) as the funds managed by the same management company are usually prevented from investing in the same entrepreneurial firm to avoid conflicts of interest among the participants in different funds. Laine and Torstila (2003) relate the size of a venture capital firm primarily to reputation and experience, and the size of a fund to the breadth of the universe of the investment opportunities available.

${ }^{200}$ For robustness checks, the above analysis (binary logistic regressions with the 50 percent cut-off) was repeated using:
}

- Binary logistic regressions with an 80 percent cut-off; 
with syndication ratio when funds were three years old. Only the location variable was statistically significant in the analysis of syndication ratio when funds were five years old and as of December 2009, with funds situated in the Prairies or the Atlantic provinces being more likely to have low syndication ratios. This may be indicative of the challenge faced by small funds in those regions searching for a large syndication partner (recall that a collective total of only four funds with more than $\$ 165$ million CDN under management were located in those provinces).

The analysis shows that fund size is not a significant determinant of syndication frequency. This finding is not consistent with Hypothesis 2 that small venture capital funds syndicate more often than large ones. However, this result is consistent with the view that many small funds look to the few large funds as syndication partners in order to provide sufficient capital for their investee firms. This results in a high level of syndication activity for all funds, small and large. This view arises directly from the previously noted finding that large Canadian venture capital funds hold an extremely high number of portfolio companies (more than three times as many as counterparts in the United States). Moreover, this finding is consistent with the Bottleneck prediction: that syndication activity is high in communities comprised of a large number of small funds and a small number of large funds. Perhaps the key finding from Table V-5 is that the

- Multinomial logistic formulations (groups = funds that had not made any investments by the time of the measurement. funds with syndication ratio of 100 percent, funds with syndication ratios of zero or more and less than 100 percent);

- OLS regressions (with and without natural $\log$ transformation of syndication ratio).

The findings with respect to the significance of fund size on syndication ratio did not differ across these approaches. The analysis was also repeated for the sub-sample comprising of private independent funds but again. results did not materially differ. The results of these robustness checks are available upon request. 
level of syndication activity is so uniformly high and widespread in Canada that it is almost impossible to detect a significant difference in propensity to syndicate across Canadian venture capital funds. 
Table V-5: Logistic Regression: Syndication Ratio

\begin{tabular}{|c|c|c|c|c|c|c|c|c|c|c|c|c|c|}
\hline & & \multicolumn{4}{|c|}{ Cut-off Point=3 Years } & \multicolumn{3}{|c|}{ Cut-off Point $=5$ Years } & \multicolumn{5}{|c|}{ Cut-off Point=As of 2009} \\
\hline & & B & S.E. & Wald & Sig. & B & S.E. & Wald & Sig. & B & S.E. & Wald & Sig. \\
\hline Type & $\begin{array}{l}\text { Non Private } \\
\text { Independent }\end{array}$ & -1.049 & 0.721 & 2.119 & 0.146 & -0.65 & 0.911 & 0.51 & 0.475 & -0.045 & 0.601 & 0.006 & 0.941 \\
\hline \multirow[t]{4}{*}{ Location } & & & & 2.103 & 0.551 & & & 3.756 & 0.289 & & & 6.942 & 0.074 \\
\hline & $\mathrm{BC}$ & 0.373 & 0.971 & 0.148 & 0.7 & 18.52 & $\begin{array}{r}8242.5 \\
4\end{array}$ & 0 & 0.998 & 0.519 & 0.878 & 0.35 & 0.554 \\
\hline & $\mathrm{QC}$ & 0.136 & 0.937 & 0.021 & 0.885 & -0.173 & 1.24 & 0.019 & 0.889 & 0.062 & 0.78 & 0.006 & 0.937 \\
\hline & $\begin{array}{l}\text { Prairies and } \\
\text { Atlantic provinces }\end{array}$ & -1.214 & 1.008 & 1.45 & 0.229 & -1.801 & 0.964 & 3.489 & 0.062 & -1.522 & 0.718 & 4.5 & 0.034 \\
\hline \multirow[t]{4}{*}{ Size } & & & & 3.658 & 0.301 & & & 0.67 & 0.88 & & & 1.657 & 0.647 \\
\hline & $\begin{array}{l}\text { Very Small } \\
(\mathrm{x}<30)\end{array}$ & -0.436 & 1.347 & 0.105 & 0.746 & -0.299 & 1.37 & 0.048 & 0.827 & -0.545 & 0.931 & 0.343 & 0.558 \\
\hline & $\begin{array}{l}\text { Small } \\
(30<=x<75)\end{array}$ & -1.79 & 1.194 & 2.248 & 0.134 & -0.91 & 1.246 & 0.534 & 0.465 & -1.078 & 0.876 & 1.517 & 0.218 \\
\hline & Large $(165<=x)$ & -1.38 & 1.411 & 0.956 & 0.328 & -0.444 & 1.889 & 0.055 & 0.814 & -0.732 & 1.087 & 0.453 & 0.501 \\
\hline Age & & 0.049 & 0.052 & 0.862 & 0.353 & 0.025 & 0.084 & 0.085 & 0.771 & 0.002 & 0.033 & 0.004 & 0.953 \\
\hline \multicolumn{2}{|l|}{ Constan } & 3.179 & 1.218 & 6.816 & 0.009 & 3.238 & 1.332 & 5.91 & 0.015 & 3.103 & 0.927 & 11.21 & 0.001 \\
\hline $\mathbf{N}$ & & 96 & & & & 95 & & & & 161 & & & \\
\hline \multicolumn{2}{|c|}{ Syndication Ratio $\leq \mathbf{5 0 \%}$} & 11 & & & & 7 & & & & 15 & & & \\
\hline \multicolumn{2}{|c|}{ Syndication Ratio $>50 \%$} & 85 & & & & 88 & & & & 146 & & & \\
\hline \multicolumn{2}{|c|}{-2 Log Likelihood } & 60.138 & & & & 41.028 & & & & 91.728 & & & \\
\hline \multicolumn{2}{|c|}{ Cox \& Snell R Square } & 0.082 & & & & 0.09 & & & & 0.049 & & & \\
\hline \multicolumn{2}{|c|}{ Nagelkerke R Square } & 0.161 & & & & 0.22 & & & & 0.105 & & & \\
\hline
\end{tabular}

* Dependent variable is a binary variable equal to 1 if the syndication ratio is greater than $50 \%$; 0 otherwise. 
* Type is a binary variable equal to 0 if the fund is a private independent (the base category) fund, 1 if it is not (including institutional investor, corporate financial, corporate industrial, LSVCCs, Provincial VCC, government).

* Location is a categorical variable for the fund's location (base category $=$ Ontario).

* Size is the amount of capital under management of the fund at the time of the cut-off point (base category = Middle $(75<=x<165$ in $\$$ million CDN)).

* Age is the age of the management company of the fund at the time of the cut-off point.

* The analyses employ, as alternate specifications, each of the following four measures of experience to ensure robustness of findings: the age of the management company of the fund, the number of funds the management company of the fund has raised, the number of entrepreneurial firms in which the management company of the fund has invested, and the number of exits the management company of the funds has experienced, by the time of each cut-off point. For each of the four measures of experience, a natural log and categorical transformations are also attempted (except for the number of exit variable, which produces a large number of missing values when transformed to the natural logarithm (i.e., there are a number of funds that have not attained a successful exit). For the sake of brevity, however, the specification using age of fund (as a natural number value) as an experience variable is reported here. Results of specifications with other experience measures (and with/without the natural log/categorical transformations) do not differ from the above, and are available upon request. 


\section{1-2-2. Logistic Regression Model: First Rounds}

Hypothesis 2 was also investigated using a logistic regression framework with the individual deal as the unit of analysis. Two logistic models were employed, one for firstround deals and the second for later-round deals. For first-round deals, the dependent variable is a binary variable set equal to 1.0 when the deal is syndicated and set equal to 0.0 when it is made by a sole investor. The full model is specified by:

$$
\operatorname{logit}\left[\pi\left(S Y N ?_{,, 1}\right)\right]=\alpha_{0}+\alpha_{1} * S I Z E_{l / k, l}+\alpha_{2} * S T A G E_{J, l}+\tilde{\alpha}_{3} * \tilde{C}_{\text {ontrol }}
$$

where: $\operatorname{logit}\left[\pi\left(S Y N ?_{,, I}\right)\right]=\log \left(\frac{\pi\left(S Y N ?_{, t}\right)}{1-\pi\left(S Y N ?_{,, t}\right)}\right)$, where $\pi\left(S Y N ?_{, 1}\right)=$ probability that the $1^{\text {st }}$ round investment in entrepreneurial firm $j$ is syndicated.

$S I Z E_{l / k, l}=\quad$ Measures of size of venture capital fund $i$ or syndicate $k$ backing entrepreneurial firm $j$ at $1^{\text {st }}$ financing round.

$S T A G E_{J, I}=\quad$ Measures of the level of development of investee firm $j$ at $1^{\text {st }}$ financing round.

$\tilde{C}_{\text {ontrol }}=\quad$ A vector of variables controlling for the characteristics of the deal, as well as venture capital fund $i$ (or syndicate $k$ ) and entrepreneurial firm $j$ at $1^{\text {st }}$ financing round.

For deals made by one venture capital fund (as in the case of sole investments), the size of the venture capital investor is measured by the amount of capital under the fund's management at the time the deal was made. ${ }^{201}$ For deals made by more than one fund (that is, for syndicated investments), the size of the syndicate is measured by the amount of capital under management of the largest fund in the syndicate (also measured at the time when the deal was made). Deals are then classified into five quintiles based on the

\footnotetext{
${ }^{201}$ In the case of private independent funds, the amount of capital under management is usually fixed over the life of the fund but this is not the case for other types of funds.
} 
investor's/syndicate's size: very small (capital under management less than $\$ 30$ million $\mathrm{CDN}$ ), small (greater than or equal to 30 million, less than 75 million), mid (greater than or equal to 75 million, less than 165 million), large (greater than or equal to 165 million, less than 500 million), and very large (greater than or equal to 500 million). ${ }^{202}$ Hypothesis 2 expects a higher probability of syndication when investors are small.

The above logistic model (2) as well as model (3) (which will be presented in the next sub-subsection: logistic regression for later rounds) are also used to test Hypothesis 3, which predicts more frequent syndication for later financing rounds (as investee firms grow). Venture capitalists - especially smaller funds - become more likely to be financially constrained, and thus face greater necessity of syndication as a portfolio company grows and requires larger amounts of capital. Accordingly, Hypothesis 3 asserts that the frequency of syndication is higher as investee firms grow and require greater amounts of capital for later financing rounds. It therefore includes three measures of the investee firm's level of development as independent variables, defined as follows.

- Financing round. As noted, venture capitalists usually make their financings in several financing rounds that typically coincide with meaningful steps in the development of the entrepreneurial firm; hence, a round number can be interpreted as a measure of investee firm development. A shortcoming of this

202 Descriptive statistics have revealed that Canadian large funds generally have a large number of entrepreneurial firms in their portfolios, participating in a high percentage of venture capital transactions made in Canada (see IV-2-3 and V-1-1). This makes the size distribution close to categorical rather than continuous. See Section three for discussions about the challenges associated with the estimation of size of a syndicate, as well as various alternative measures of the size of a syndicate that were also used for robustness checks. 
variable is that the interval between consecutive rounds (and thus frequency of financing rounds) can vary depending on the characteristics (the risk level, in particular) of the investee's business and the size of the investor (that is, small funds, due to their limited ability to invest large sums, often make relatively small investments requiring more frequent rounds). Moreover, it is likely that entrepreneurial firms receive their first venture capital investment at different points of development.

- Time since the first venture capital investment. The age of the firm is often used in the finance literature as a measure of company progress; however, this measure is unavailable in the data. As a proxy, therefore, this study uses the time since the first venture capital investment. This is not unreasonable in that, for many firms, the business might exist at the idea stage for many years without development (until it receives venture capital). Still, "time since the first investment" is not flawless, as the speed of development is likely to differ across different entrepreneurial firms (for example, Cumming and MacIntosh (2001b) and Lerner (1994b) argue that medical products require longer time to develop). Moreover, as in the case of the financing round number, it is likely that firms receive their first venture capital investment at different points of development.

- Amount of venture capital disbursed. The idea behind Hypothesis 3 is that entrepreneurial firms typically require progressively greater amounts of financing as they grow, increasing the necessity of (additional) syndication. Accordingly, it 
is consistent with this hypothesis to measure the investee's level of development using the amount of capital it required at the time of the financing round, proxied by the amount disbursed. As a caveat, this measure might be misleading because the amount invested might be related to the size of the investor funds: a firm may receive a smaller amount of capital when backed by a smaller venture capital fund. ${ }^{203}$

An investee firm's level of development potentially affects venture capitalists' syndication behaviour in two opposite ways. On the one hand (as hypothesized here), a more mature company generally requires a larger capital infusion and this is likely to necessitate (further) syndication. Conversely, as an investee firm develops, informational asymmetry, uncertainty about future prospects, and the need for assistance and monitoring from venture capitalists all diminish (as discussed in II-2-2-2). If venture capitalists syndicate the investment in order to mitigate informational problems, reduce risks, or provide better assistance to the investee, syndication activities will be reduced with the growth of the investee. Thus, while Hypothesis 3 expects a positive impact of investee company's growth on the probability of the entrance of a new investor into the syndicate (because investee's growth means a greater amount of capital required), there is the possibility that one (or some, or all) of the three measures for investee growth might

\footnotetext{
${ }^{203}$ The "stage of development" variable (seed, start-up, other early stage, expansion, and other stage (see II1-1-2 for detail)) was not used because it is highly subjective and subject to systemic error. A given investment may be labeled as a "later" or "expansion" stage by a very small venture capital fund that specializes in seed stage investments. The same investment might be viewed as an "early" stage by a large fund that specializes in expansion stage investments. In effect. stage is subjective and there are no standards across funds.
} 
exhibit a negative coefficient (because investee's growth means a reduction of uncertainty about its prospects). This discussion highlights the need to interpret carefully the results of the analysis reported here. ${ }^{204}$

In the analysis of first round investments, only the amount disbursed variable is included, as the other two are fixed across observations. For the examination of later round investments (in the following sub-subsection and thereafter), the analysis attempts alternative specifications: using all three measures together, using each of the three measures separately, using two of the measures, etc., since each of the three measures has its own pros and cons. ${ }^{205}$ Hypothesis 3 predicts a positive coefficient for the measures of the investee's development.

Control variables employed in the analysis include the industry sector of the investee firm, the location of the deal, the type of fund/syndicate, the level of experience of the fund/syndicate and the presence/absence of foreign investor(s). See Appendix I for the definitions of, and more detailed discussions on, control variables.

\footnotetext{
${ }^{204}$ Existing studies report inconsistent results as to the relation between investee's development and syndication. Giot and Schwienbacher (2006) observe an increasing number of investors in a syndicate as a firm develops from early to later stages but Bygrave (1987) reports a negative association between the stage of development and the number of investers in a syndicate. Hopp and Rieder (2006) find a negative association between investee age and the probability of syndicate, as well as the number of investors in a syndicate. This result indicates that: (1) the "stage of development" variable may not be a reliable measure for the level of the investee's development (as discussed in the previous footnote); and, (2) while there is a high probability of the investee's level of development having impacts on syndication, its direction of influence is uncertain as there are potentially two opposite ways in which the investee's level of development influences venture capitalists' syndication practices.

${ }^{205}$ For the sake of brevity, the result based on the specification with all three measures is reported here. The results of the other specifications (which excludes one (or two) of these measures) led to the same conclusions and are available upon request.
} 
For the first round investments, an ideal analysis would be an investigation of the relationship between the size of the lead investor (who discovered the entrepreneurial firm and made a decision as to whether the deal should be syndicated) and the probability of the deal being syndicated. However, the data does not provide information on the identity of the lead investors. This makes it infeasible to investigate the relationship between the lead investor's size and the probability of the deal being syndicated; the best alternative is to examine the relationship among the size of all the investors participating in the deal and the probability of the deal being syndicated. This, though, creates a problem in the interpretation of the results. Hypothesis 2 states that smaller funds syndicate more often, expecting a positive and significant coefficient for small fund size on the probability of syndication. However, if in many cases the lead investor, who discovered the entrepreneurial firm in which to invest, is small and thus decides to invite a large fund to the deal, higher odds ratio for syndication for deals with large funds will be observed. For this reason, although Hypothesis 2 expects a positive and significant coefficient for small fund size, it is not conclusive whether the hypothesis should be rejected or not, even if we find a positive and significant coefficient for large fund size. Taking the above shortcoming into account, the results of the first round logistic regression (presented in Table V-6) are considered. 
Table V-6: Logistic Regression on the Odd Ratio of Syndication (First Rounds)

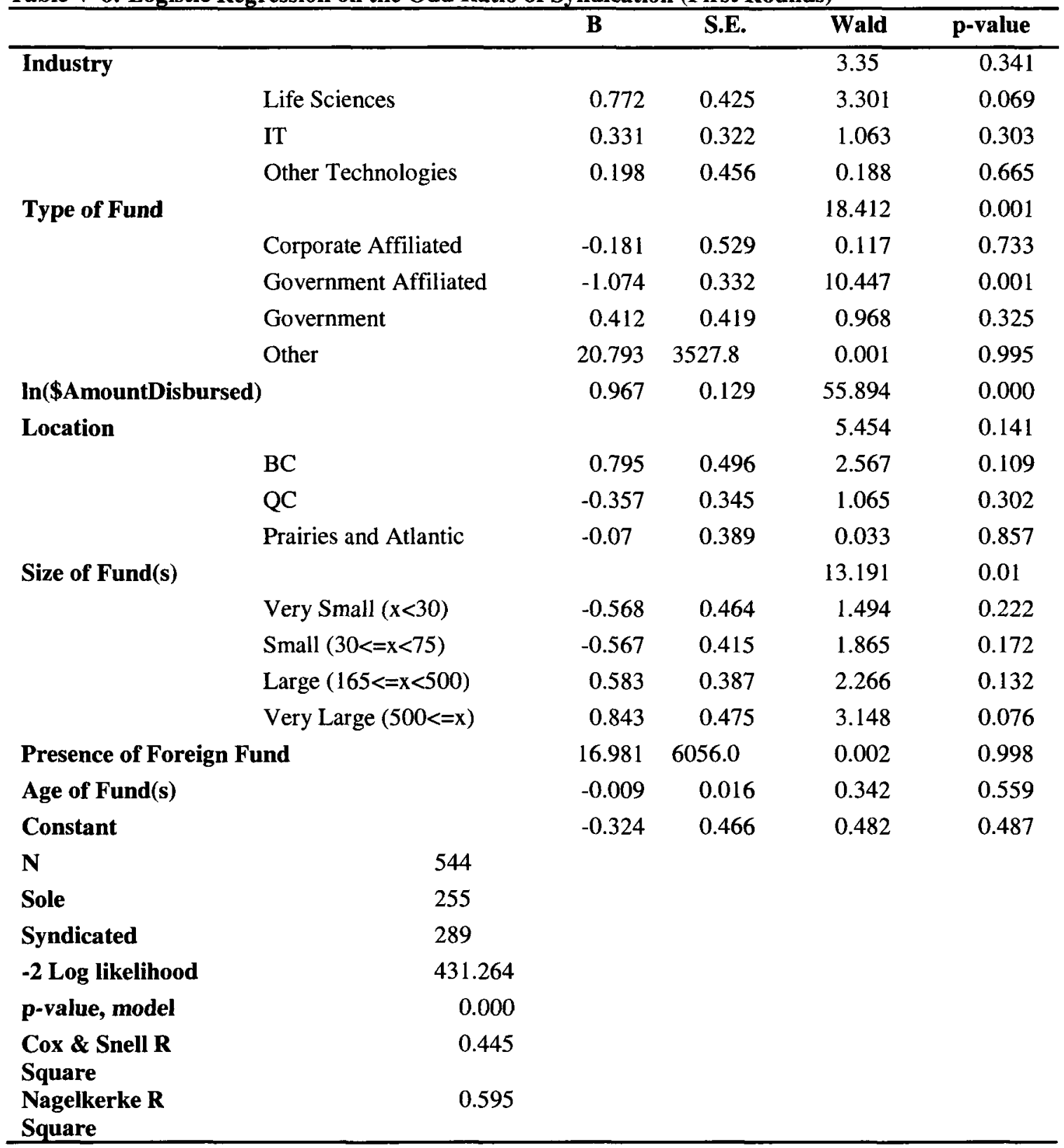

* Dependent variable is a binary variable equal to 1 if the deal is syndicated; 0 otherwise.

* Industry is the sector in which the investee company operates (base category $=$ Traditional).

* Type is a categorical variable for the type of fund (if sole investment) or the type of the funds that form the majority of funds in the syndicate (if syndicated investment, base category = private independent).

* $\ln (\$$ AmountDisbursed) is the natural logarithm of the dollar amount of venture capital disbursed to the investee at the financing round (in million $\mathrm{CDN}$ ).

* Location is the province in which the investee is located (base category = Ontario). 
* Size is the amount of capital under management of the fund at the time the deal was made (if sole investment) or the amount of capital under management of the largest fund in the syndicate at the time the deal was made (if syndicated investment (base category $=$ Middle $(75<=x<165$ in $\$$ million CDN)).

* Presence of foreign investor takes the value 1 if there is at least one foreign fund participating in the deal, 0 otherwise.

* Age is the age of the management company of the fund (if sole investment) or the age of the oldest management company of the funds participating in the deal (if syndicated investment). ${ }^{206}$

${ }^{206}$ The analyses employ, as alternate specifications, each of the following four measures of experience to ensure robustness of findings: the age of the management company of the fund, the number of funds the management company of the fund had raised, the number of entrepreneurial firms the management company of the fund had invested, and the number of exits the management company of the funds had experienced, at/by the time the deal was made. For syndicated deals, experience is measured by the level of experience of the most experienced fund in the syndicate. For each of the four measures of experience, a natural $\log$ and categorical transformations are also attempted (except for the number of exit variable, which produces a large number of missing values when transformed to the natural logarithm, i.e., there are a number of funds that have not attained a successful exit). For the sake of brevity, however, the specification using the age of fund (as a natural number value) as an experience variable is reported. Results of the specifications with other experience measures (and with/without the natural log/categorical transformations) do not differ from the above and are available upon request. 
Several findings are apparent from the estimation of the logistic model presented in Table V-6.

- Investments in the life sciences sector are more likely to be syndicated (p-value0.069). Medical products take longer to develop (Cumming and MacIntosh, 2001b; Lerner, 1994b) so investments in this sector may be viewed as riskier.

- There is no significant difference in syndication activities in terms of the location of the investment.

- First-round deals are less likely to be syndicated when the investor is an LSVCC or a Provincial VCC ( $\mathrm{p}$-value $=0.001$ ). This may be because government-affiliated funds are young (Cumming and MacIntosh, 2006; 2002; 2001a) and, therefore, do not have a well-established network position within the venture capital community through which they could find a syndication partner (see II-1-2-5). Government-affiliated funds may also be willing to make early-stages investments that private-sector funds eschew (Cumming, 2006). Alternatively, recall that eight large government-affiliated funds participated in 32 percent of all deals used for the analyses (see IV-2-3). They are large and have less need for an additional source of capital. This result may be a reflection of those eight funds' participation in a large number of deals.

- The level of experience of the fund/the most experienced fund in the syndicate is insignificant. 
- The dollar amount of venture capital disbursed to the investee is positively related with the probability of syndication ( $p$-value $=0.000$ ), a finding consistent with Hypothesis 3: the more the investee firm grows and the greater the amount of venture capital it requires, the more likely that the deal will be syndicated. ${ }^{207}$

- The coefficient for the dummy variable "presence of foreign fund" is unusually large (though insignificant) because deals with at least one foreign fund were all syndicated (27 observations): no foreign fund invested in an entrepreneurial firm in Canada by itself for a first financing round.

- The coefficients and the p-values for the size of the investor(s) were contrary to Hypothesis 2. While Hypothesis 2 states that small venture capital funds syndicate more often, the empirical observation indicates that large funds are more likely to make syndicated investments. The overall size variable is significant $(\mathrm{p}$-value $=$ 0.01 ), suggesting that large (small) funds were significantly more likely to make syndicated (sole) investments. However, recall that this regression analysis examines the impact of the size of all the investors participating in the deal (rather than the size of the lead investor who discovered the entrepreneurial firm and initiated the deal). It is therefore possible to interpret this result as a manifestation that large funds are more likely to invest in deals initiated by another (presumably

\footnotetext{
${ }^{207}$ As discussed, a two-way interaction between the two variables is likely: (1) because the investee requires a greater amount of capital, the deal is syndicated; and, (2) the greater capital availability of a syndicated deal (as opposed to a sole investment) enables the investee to receive a greater amount of capital.
} 
small) venture capitalist. Arguably, deals are less likely to be syndicated when the (small) lead investor is unable to find a large fund as a syndicate partner or has no need for additional sources of capital (the investee is assumed to be small at the first financing round, requiring a smaller amount of capital). For this reason, it is premature to reach a conclusion, based on this result only, regarding whether Hypothesis 2 is empirically supported. ${ }^{208}$

\section{1-2-3. Logistic Regression: Later Rounds}

For second and later rounds, the following logistic regression model tests Hypotheses 2 and 3 by examining the impacts of the size of the incumbent venture capital funds and the investee's growth on the incumbent investors' decision as to whether to add a new investor in a deal:

$$
\operatorname{logit}\left[\pi\left(A D D ?_{j, t}\right)\right]=\alpha_{0}+\alpha_{l} * S I Z E_{l / k, t}+\alpha_{2} * S T A G E_{j, t}+\widetilde{\alpha}_{3} * \tilde{C}_{\text {ontrol }},
$$

where: $\operatorname{logit}\left[\pi\left(A D D ?_{j, t}\right)\right]=\log \left(\frac{\pi\left(A D D ?_{, t,}\right)}{1-\pi\left(A D D ?_{, t, t}\right)}\right)$, where $\pi\left(A D D ?_{j, 1}\right)=$ probability of new investor entrance (i.e., coded as 1.0 when one (or more) new venture capital fund(s) is added to investment in investee firm $j$ at $t^{\text {th }}$ financing round).

$S I Z E_{i / k, t}=\quad$ Size measure of incumbent venture capital fund $i$ or syndicate $k$ comprised of incumbent funds at $t^{\text {th }}$ financing round.

\footnotetext{
${ }^{208}$ Table V- 6 presents the estimation of the full model. In addition, a base model was estimated, one which omits the size-related variables, namely, size of fund(s) and the presence of foreign fund. The collective addition of the block of variables that seek to measure size significantly improved the goodness of fit (pvalue, block $=0.01$ ).
} 


$$
\begin{array}{ll}
\text { STAGE }_{j, t}= & \begin{array}{l}
\text { Measures for the level of development of investee firm } j \text { at } t^{\text {th }} \\
\text { financing round (see below (1-1-3)). }
\end{array} \\
\tilde{\text { Control }}= & \begin{array}{l}
\text { A vector of variables controlling for the characteristics of the } \\
\text { deal as well as venture capital fund } i \text { (or syndicate } k \text { ) and } \\
\text { entrepreneurial firm } j \text { at } t^{\text {th }} \text { financing round. }
\end{array}
\end{array}
$$

The dependent variable is the odds ratio of the entry of one (or more) new fund(s) to the syndicate. Because it is the incumbent fund(s) that decides whether to add a new investor, the size measure included on the right hand side of the equation accounts for the financial capability of the incumbent(s). As in the previous analysis, the size of the incumbent fund is measured by the amount of capital under management of the fund, and the size of the incumbent syndicate is measured by the amount of capital under management of the largest fund, both measured at the time when the deal was made. Deals are then ranked and classified into five quintiles based on the incumbent investor's/syndicate's size.

In addition, two variables, which are considered to be related to the capital availability of the fund/syndicate, are included: (1) the presence of a foreign investor $(=1.0$ when at least one foreign fund participates in the deal; $=0.0$ for deals with no foreign fund involvement); ${ }^{209}$ (2) the number of venture capital funds involved in the syndicate (a

\footnotetext{
${ }^{209}$ In the previous analysis (model 2), the variable "presence of foreign investor" is a control variable whereas in model 3 , and thereafter, this variable is one of the explanatory variables to measure the size of the incumbent funds. The rationale is as follows. In model 2, the size and characteristics of all the investors in the deal are taken into account. It is expected that foreign funds seldom make a sole investment in a Canadian firm due to costly monitoring and value-adding activities associated with distant investments. This variable is, therefore, expected to have a positive correlation with the probability of a deal being syndicated (meaning: it is used for controlling the effect of distant investments). In fact, no foreign fund made a sole investment in a Canadian entrepreneurial firm for the first financing round. In model 3 , and thereafter, the size and characteristics of only the incumbent funds are taken into account. It is expected that the presence of one (or more) foreign fund in an incumbent syndicate means greater capital availability among incumbent investors, reducing the probability of the entrance of a new investor (meaning: the presence of the foreign investor variable is one of the explanatory variables to measure the size of the
} 
categorical variable with three levels: only one incumbent investor; two to four incumbents; five or more incumbents). All three variables are expected to have a negative and significant impact on the probability of the entrance of a new investor(s) to the syndicate. $^{210}$

As in the previous analysis, the logistic model (3) also tests Hypothesis 3, which predicts more frequent syndication for later financing rounds (as investee firms grow). It therefore includes the three measures of the investee firm's level of development: financing round (a categorical variable with four levels: second round; third; fourth; and, fifth or later round); time since the first venture capital investment; and, the natural logarithm of the amount of venture capital disbursed at the time of the financing round. ${ }^{211}$

\footnotetext{
incumbent syndicate). No first round investment made solely by foreign funds means no incumbent syndicate consisting of only foreign funds (foreign funds have already had one (or more) local investor as a syndicate partner). Thus, it is unlikely that syndicates with a foreign fund(s) will add a new investor to mitigate the problems associated with distant investments. Nevertheless, if the incumbent syndicate consists of a large number of foreign funds, they may decide to add a local investor for a further reduction of the problem of the distant investment. This effect is controlled by one category of "type" variable, namely "Foreign", which takes the value one when the majority of the funds in the incumbent syndicate is formed by foreign funds. This category is expected to have a positive impact on a new investor entry (this and the "presence of foreign fund" variable are correlated, but not perfectly. For example, in the sample used for Model 3, there are 169 (out of 789) cases where at least one foreign fund is present (i.e., "presence of foreign fund" $=1$ ) whereas there are 62 cases where the majority of funds in the incumbent syndicate is formed by foreign funds (i.e., "Foreign" category of type variable $=1$ ).

${ }^{210}$ See section three of this chapter for a detailed discussion on measuring the size of a syndicate.

211 The previous sub-subsection (2-2-2: the analysis of first round investments) pointed out the potential problem associated with the amount disbursed: it may be related to the size of the investors' funds, such that the firm receives a smaller amount of capital if it is backed by a smaller venture capital fund. This problem, however, may be less serious in this analysis of later financing rounds. In the previous analysis of the first round investments, the size of all the investors in the, which could have a direct impact on the amount disbursed, deal is on the right hand side of the equation. On the other hand, in this analysis of the later financing rounds, the size of the incumbent investor(s) only is on the right hand side while the capital availability of the incumbent(s) and entrant(s) collectively has a direct relation to the amount disbursed.
} 
The control variables included in the analysis are the industry sector of the investee, the location of the deal, the type of the fund/syndicate, and the level of experience of the fund/syndicate. See Appendix I for the definitions of, and more detailed discussion on, control variables. 
Table V-7: Logistic Regression on Probability of New Investor Entry (Later Rounds)

\begin{tabular}{|c|c|c|c|c|c|}
\hline \multirow{2}{*}{ Industry } & & \multirow[t]{2}{*}{ B } & \multirow[t]{2}{*}{ S.E. } & \multirow{2}{*}{$\frac{\text { Wald }}{4.319}$} & \multirow{2}{*}{$\begin{array}{l}\text { Sig. } \\
0.229\end{array}$} \\
\hline & & & & & \\
\hline & Life Sciences & 0.182 & 0.361 & 0.253 & 0.615 \\
\hline & IT & 0.352 & 0.333 & 1.112 & 0.292 \\
\hline & Other Technologies & -0.316 & 0.447 & 0.498 & 0.48 \\
\hline \multicolumn{2}{|c|}{$\ln$ (\$AmountDisbursed) } & 0.954 & 0.087 & 121.294 & 0 \\
\hline \multirow[t]{4}{*}{ Round\# } & & & & 11.071 & 0.011 \\
\hline & 3 rd & -0.601 & 0.247 & 5.903 & 0.015 \\
\hline & 4th & -0.832 & 0.301 & 7.621 & 0.006 \\
\hline & 5 th or more & -1.013 & 0.339 & 8.911 & 0.003 \\
\hline \multicolumn{2}{|l|}{ Time since 1st Inv. } & 0.041 & 0.02 & 4.245 & 0.039 \\
\hline \multirow[t]{6}{*}{ Type } & & & & 3.996 & 0.55 \\
\hline & Corporate Affiliated & 0.201 & 0.402 & 0.25 & 0.617 \\
\hline & Government Affiliated & -0.057 & 0.293 & 0.038 & 0.846 \\
\hline & Government & -0.168 & 0.386 & 0.188 & 0.664 \\
\hline & Foreign & 0.732 & 0.431 & 2.877 & 0.09 \\
\hline & Other & 0.061 & 0.282 & 0.046 & 0.829 \\
\hline \multirow[t]{5}{*}{ Location } & & & & 15.233 & 0.004 \\
\hline & $\mathrm{BC}$ & -0.474 & 0.346 & 1.87 & 0.171 \\
\hline & $\mathrm{QC}$ & 0.586 & 0.301 & 3.788 & 0.052 \\
\hline & Prairies and Atlantic & -0.791 & 0.513 & 2.375 & 0.123 \\
\hline & Other & -0.191 & 0.274 & 0.488 & 0.485 \\
\hline \multicolumn{2}{|l|}{ Age } & 0.026 & 0.01 & 7.507 & 0.006 \\
\hline \multirow[t]{5}{*}{ Size } & & & & 24.205 & 0 \\
\hline & Very Small $(x<30)$ & 0.502 & 0.444 & 1.277 & 0.259 \\
\hline & Small $(30<=x<75)$ & 0.877 & 0.373 & 5.532 & 0.019 \\
\hline & Large $(165<=x<500)$ & 0.14 & 0.297 & 0.224 & 0.636 \\
\hline & Very Large $(500<=x)$ & -0.904 & 0.336 & 7.243 & 0.007 \\
\hline \multicolumn{2}{|c|}{ Presence of Foreign Fund } & -0.658 & 0.306 & 4.618 & 0.032 \\
\hline \multicolumn{2}{|l|}{ \# of Incumbents } & & & 2.85 & 0.24 \\
\hline & $2,3,4$ & 0.348 & 0.289 & 1.442 & 0.23 \\
\hline & 5 or more & -0.036 & 0.404 & 0.008 & 0.929 \\
\hline \multicolumn{2}{|l|}{ Constant } & -1.328 & 0.532 & 6.227 & 0.013 \\
\hline \multicolumn{2}{|r|}{789} & & & & \\
\hline \multicolumn{2}{|l|}{ Added } & & & & \\
\hline \multicolumn{2}{|l|}{ Not Added } & & & & \\
\hline-2 Log likelihood & 777.448 & & & & \\
\hline p-value, model & 0.000 & & & & \\
\hline
\end{tabular}




\begin{tabular}{lr}
\hline Cox \& Snell R & 0.321 \\
Square & \\
Nagelkerke R & 0.43 \\
Square & \\
\hline
\end{tabular}

* Dependent variable is a binary variable equal to 1 if one or more new investors enter into the deal at the time of the financing round; 0 otherwise.

* Industry is the sector in which the investee company operates (base category $=$ Traditional).

* $\ln (\$$ AmountDisbursed) is the natural logarithm of the dollar amount of venture capital disbursed to the investee at the financing round (in million CDN).

* Round\# is the financing round number (base category $=2^{\text {nd }}$ round).

* Time since 1st Inv. Is the number of days since the first venture capital investment to the current round (in 100 days).

* Type is the type of fund (if there is one incumbent investor) or the type of funds that form the majority of funds in the incumbent syndicate (if there are more than one incumbent investors, base category = private independent).

* Location is the province in which the fund and the investee are located (if there is one incumbent investor), or the province in which the funds that form the majority of funds in the incumbent syndicate and the investee are located (if there are more than one incumbent investors, base category = Ontario).

* Age is the age of the management company of the fund (if there is one incumbent investor) or the age of the oldest management company of the funds participating in the deal (if there is more than one incumbent investor).

* Size is the amount of capital under management of the fund (if there is one incumbent investor) or the amount of capital under management of the largest fund in the incumbent syndicate at the time the deal was made (base category $=$ Middle $(75<=x<165$ in $\$$ million CDN)).

* Presence of foreign investor takes the value of 1 if there is at least one foreign fund in the incumbent syndicate, 0 otherwise.

* \# of Incumbents is the number of incumbent funds in the deal at the time the deal was made (base category $=$ one).

* The analyses employ, as alternate specifications, each of the following four measures of experience to ensure robustness of findings: the age of the management company of the fund, the number of funds the management company of the fund had raised, the number of entrepreneurial firms the management company of the fund had invested, and the number of exits the management company of the funds had experienced, at/by the time the deal was made. For deals with more than one incumbent fund, experience is measured by the level of experience of the most experienced fund in the incumbent syndicate. For each of the four measures of experience, a natural $\log$ and categorical transformations are also attempted (except for the number of exit variable, which produces a large number of missing values when transformed to the natural logarithm, i.e., there are a number of funds that have not attained a successful exit). For the sake of brevity, however, the specification using the age of the fund (as a natural number value) as an experience variable is reported. Results of specifications with other experience measures (and with/without the natural $\log$ /categorical transformations) do not differ from the above, and are available upon request. 
Table V-7 presents the results of estimation of the logistic model of the probability of adding a new investor(s) to an existing investment. The findings include that:

- The location of the deal was significant ( $p$-value $=0.004)$. When the majority of investors and the investee firms were located in Quebec, a new investor was more likely to be added. The level of significance for the overall location variable as well as the coefficients and significance levels for four location categories suggest that the likelihood of a new investor entry for deals in Quebec is significantly higher than those in Ontario at an approximately five percent level, and is significantly higher than those in other provinces (the Prairie and the Atlantic provinces in particular) at a less than one percent level. This result may reflect, as discussed earlier, the relatively large number of large funds available as potential syndicate partners in the Quebec community;

- The experience of the investor(s), measured by the age of the oldest management company of the funds among incumbents, was also significant ( $\mathrm{p}$-value=0.006). The more experienced the investor/syndicate, the more likely a new investor is added. This is counterintuitive from the "resource-based" view of syndication, which predicts experienced venture capitalists have less need of other venture capitalists' expertise, and thus less incentive to syndicate (see section two of Chapter II). This result is not, however, counterintuitive from the bottleneck hypothesis point of view, which suggests the possibility that experienced venture capitalists' well-established central positions within the venture capital 
community enables them to find additional sources of capital (an additional syndicate partner) relatively easily;

- The type of investor(s) was insignificant ( $p$-value $=0.55$ ), with one category marginally significant ( $\mathrm{p}$-value=0.09). As expected, when the incumbent syndicate is formed mainly by foreign funds, a new investor is more likely to be added in order to further reduce the problems associated with distant investments (costly monitoring and value-adding, severe information asymmetry, etc., Bruining, Verwaal, Lockett, Wright, and Manigart, 2006; Hopp and Rieder, 2006; Sorenson and Stuart, 2001; see II-2-2-2 and II-2-3-2). There was no significant difference in the likelihood of a new investor entrance among investee firms in different sectors;

- The dollar amount of venture capital disbursed at the time of the financing round was positively related to the likelihood of the entry of a new investor ( $p$-value $=$ 0.000). Assuming that the amount disbursed reflects the amount of capital required by the investee, this result strongly supports Hypothesis 3, that the investee firms' requirements for greater amounts of capital increase as they grow, which also increases the need for syndication;

- Time since the first venture capital investment was also positive and significant (p-value $=0.039)$, leading to a similar conclusion as above; 
- The round number variable was also significant (p-value $=0.011$ ) but the coefficients were contrary to what was expected. While Hypothesis 3 predicts a higher probability of new investor entry for later financing rounds, the results show that a new investor is significantly more likely to enter a deal at the second round (the base category) than at subsequent rounds, and the probability of a new investor entrance decreases as round numbers increase. ${ }^{212}$ However, subsequent analyses revealed that small funds were more likely to enter at a second round but larger (and foreign) funds were more likely to participate at later rounds. The result obtained here, therefore, reflects the higher probability of a smaller fund entry at a second round;

- The size of the incumbent investor(s) appears to have a significant negative impact on a entrepreneurial team's decision whether to add a new investor to a deal ( $p$-value $=0.000$ ). Inspection of the coefficient estimates revealed that, in general, additional investors are more likely to be added when the incumbent investor is small, or when the syndicate is based on small venture capitalists rather than when the investor is large or large venture capitalist(s) is/are present in the syndicate. ${ }^{213}$ This is consistent with Hypothesis 2; and,

\footnotetext{
${ }^{212}$ It may also reflect the decreased level of uncertainty about the prospects of the investee (see the previous sub-subsection).

${ }^{213}$ A specification that includes the interaction term between the level of the investee's development (the amount disbursed) and the investor's(s') size was also attempted; however, it was insignificant.
} 
- Finally, the number of incumbent investors was insignificant, suggesting that what matters is not the number of investors a syndicate may include but whether it has one (or more) large fund. The presence of a foreign investor(s) in the syndicate significantly ( $p$-value $=0.032$ ) reduced the odds ratio of an additional new investor. This is as expected; having one (or more) large foreign fund diminishes the syndicate's necessity of a new investor to provide a sufficient amount of capital to the investee. ${ }^{214,215}$

1-2-4. Summary of Results of Hypotheses $2 \& 3$

The results of testing Hypotheses 2 and 3 are summarized as follows:

- In absolute terms, and relative to Germany, the Canadian venture capital industry exhibited a high level of syndication activity;

- The propensity to syndicate did not differ significantly across funds of different sizes, in contravention of Hypothesis 2 which posited that small venture capital funds syndicate more often. However, it became apparent that the small number of large Canadian funds was sought after by the many small funds. This has

\footnotetext{
${ }^{214}$ Note that the "foreign" category of the type variable was positive and significant ( $p$-value $=0.09$ ). When the syndicate is mostly comprised of foreign funds, it needs to add a local investor to reduce problems of distant investments. When a syndicate has a foreign fund along with a sufficient number of local investors, the necessity of additional investors is reduced, thanks to the foreign fund's deeper pockets.

${ }^{215}$ Table V-7 presents the estimation of the full model. In addition, a base model was estimated, one which omits the size-related variables, namely, the size of fund(s) and the presence of foreign fund. The collective addition of the block of variables that seek to measure size improved the goodness of fit to a statistically significant degree ( $\mathrm{p}$-value, block $=0.00$ ).
} 
resulted in a disproportionally higher number of portfolio companies comprising the portfolios of large Canadian funds (relative to funds in the United States) and high levels of syndication even for large funds. This is consistent with the bottleneck hypothesis which predicts high syndication activity in a community scarce of large funds;

- Regional differences were noted with the Prairie and Atlantic provinces exhibiting low syndication frequencies, and Quebec being relatively more likely to add new investors to deals. These results arguably reflect the industry structure of these provinces: Quebec being the province in which most of the large funds are located, and the Prairie and Atlantic provinces being those in which relatively few are located.

- The likelihood of entry of a new investor was significantly and positively associated with the amount of capital disbursed and the time since the investee firm received its first venture capital investment. The former variable was also significantly and positively related to the likelihood for first round deals to be syndicated. These results are consistent with Hypothesis 3: the more the investee firm grows and the greater the amount of venture capital it requires, the more likely that the deal is syndicated or that a new investor is added.

- With respect to first round financings, it was found that smaller funds were more likely to make sole investments whereas larger funds tended to make syndicated investments. While this is not consistent with Hypothesis 2 that suggests more 
syndication when investors are small, the fact that the lead investor could not be identified remains a caveat with respect to this interpretation: the result has alternative interpretations. If the lead investor, who discovered the entrepreneurial firm, is small and successfully finds and adds a large fund to the deal, the deal is recorded as "syndicated"; if the lead investor does not need, or is unable to find, a large fund as a syndicate partner, the deal is recorded as a sole investment.

- On the other hand, the size of the incumbent investor(s) appears to be significantly and negatively associated with the likelihood of adding a new investor to a deal. Small, and very small, incumbent syndicates were significantly more likely to add a new investor, whereas a very large incumbent(s) was significantly less likely to do so. Moreover, the presence of a foreign investor in the syndicate significantly reduced the likelihood of an addition: having one (or more) foreign fund within the syndicate appears to mitigate the need for a new investor in order to provide sufficient financing. These results support Hypothesis 2. 


\section{1-3. Hypothesis 4}

Hypothesis 4: A larger number of investors are involved in syndicates comprised of smaller funds (especially for later stages of financing as the investee firms grow).

Hypothesis 4 was tested using the Canadian sample and by undertaking comparisons between the United States and Canada.

\section{1-3-1. Canadian Analysis}

Hypothesis 4 was tested by estimating a regression model (4) of the number of investors in a syndicate at a given financing round against the size of the syndicate. A Poisson regression was employed because the number of investors is a finite and discrete number. The unit of analysis is a financing round.

$$
\log \left(S Y N D S I Z E_{j, t}\right)=\alpha_{0}+\alpha_{1} * S I Z E_{i / k, t}+\alpha_{2} * S T A G E_{j, t}+\tilde{\alpha}_{3} * \widetilde{C}_{\text {ontrol }},
$$

where: $S Y N D S I Z E_{j, t}=$ Number of investors in syndicate $k$ that finances entrepreneurial firm $j$ at $t^{\text {th }}$ financing round. ${ }^{216}$

$S I Z E_{i k, t}=\quad$ Size measures of syndicate $k$ at $t^{\text {th }}$ financing round.

$S T A G E_{j, t}=\quad$ Measures for the level of development of investee firm $j$ at $t^{\text {th }}$ financing round.

$\tilde{C}$ ontrol $_{t}=\quad \mathrm{A}$ vector of variables controlling for the characteristics of the deal, as well as venture capital fund $i$ (or syndicate $k$ ) and entrepreneurial firm $j$ at $t^{\text {th }}$ financing round.

\footnotetext{
${ }^{216}$ This variable takes the value one for standalone investment which is considered as a syndicate comprised of a single investor.
} 
Hypothesis 4 predicts that the number of investors in a syndicate is negatively related with the size of a syndicate (the smaller the investors in the syndicate, the greater the number of investors). It is also expected that the development of the investee firm increases with the number of investors in the syndicate, since greater amounts of capital are required as the investee firm grows. Table V-8 presents the results. 
Table V-8: Poisson Regression on Number of Syndicate Members (All Rounds)

\begin{tabular}{|c|c|c|c|c|c|}
\hline & & B & S.E. & Wald & Sig. \\
\hline Intercept & & 0.365 & 0.0743 & 24.098 & $\overline{0}$ \\
\hline \multirow[t]{3}{*}{ Industry } & Life Sciences & 0.329 & 0.057 & 33.407 & 0 \\
\hline & IT & 0.249 & 0.0538 & 21.402 & 0 \\
\hline & Other Technologies & 0.23 & 0.0706 & 10.63 & 0.001 \\
\hline \multirow[t]{4}{*}{ Round\# } & 2nd & 0.235 & 0.0454 & 26.732 & 0 \\
\hline & 3rd & 0.325 & 0.0516 & 39.761 & 0 \\
\hline & 4 th & 0.414 & 0.0598 & 48.03 & 0 \\
\hline & 5th or more & 0.496 & 0.0668 & 55.236 & 0 \\
\hline Presence of Foreign Fund & & 0.27 & 0.04 & 45.651 & 0 \\
\hline \multirow[t]{5}{*}{ Type } & Corporate Affiliated & -0.08 & 0.0634 & 1.586 & 0.208 \\
\hline & Government Affiliated & -0.151 & 0.0451 & 11.184 & 0.001 \\
\hline & Government & -0.071 & 0.0644 & 1.231 & 0.267 \\
\hline & Foreign & 0.093 & 0.0492 & 3.581 & 0.058 \\
\hline & Other & -0.014 & 0.04 & 0.13 & 0.719 \\
\hline \multirow[t]{4}{*}{ Location } & $\mathrm{BC}$ & -0.097 & 0.0508 & 3.614 & 0.057 \\
\hline & QC & -0.064 & 0.0421 & 2.315 & 0.128 \\
\hline & Prairies and Atlantic & -0.267 & 0.0817 & 10.669 & 0.001 \\
\hline & Other & -0.137 & 0.0396 & 11.978 & 0.001 \\
\hline \multirow[t]{4}{*}{ Size } & Very Small $(x<30)$ & -0.175 & 0.0805 & 4.703 & 0.03 \\
\hline & Small $(30<=x<75)$ & -0.036 & 0.0639 & 0.321 & 0.571 \\
\hline & Large $(165<=x<500)$ & 0.167 & 0.0489 & 11.619 & 0.001 \\
\hline & Very Large $(500<=\mathrm{x})$ & 0.157 & 0.0531 & 8.728 & 0.003 \\
\hline In(\$AmountDisbursed) & & 0.131 & 0.0121 & 118.735 & 0 \\
\hline Time since 1st Inv. & & 0.015 & 0.0029 & 26.518 & 0 \\
\hline Age & & 0.006 & 0.0014 & 20.838 & 0 \\
\hline \multirow[t]{2}{*}{$\mathbf{N}$} & 1501 & & & & \\
\hline & Value & df & Value/df & & \\
\hline Deviance & 685.466 & 1476 & 0.464 & & \\
\hline Scaled Deviance & 685.466 & 1476 & & & \\
\hline Pearson Chi-Square & 702.938 & 1476 & 0.476 & & \\
\hline $\begin{array}{l}\text { Scaled Pearson Chi- } \\
\text { Square }\end{array}$ & 702.938 & 1476 & & & \\
\hline $\begin{array}{l}\text { Likelihood Ratio Chi- } \\
\text { Square }\end{array}$ & 2211.011 & & & & \\
\hline
\end{tabular}

* Dependent variable is the number of syndicate members who participated in the deal at the financing round.

* Industry is the sector in which the investee company operates (base category = Traditional).

* $\ln (\$ A$ mountDisbursed) is the natural logarithm of the dollar amount of venture capital disbursed to the investee at the financing round (in million $\mathrm{CDN}$ ).

* Round\# is the financing round number (base category $=1$ st round). 
* Time since 1 st Inv. Is the number of days since the $1^{\text {st }}$ venture capital investment to the current round (in 100 days).

*Type is the type of fund (if there is one investor) or the type of the funds that form the majority of funds in the syndicate (if there is more than one investor, base category = private independent).

* Location is the province in which the fund and the investee are located (if there is one incumbent investor), or the province in which the funds that form the majority of funds in the syndicate and the investee are located (if there is more than one investor, base category $=$ Ontario).

* Age is the age of the management company of the fund (if there is one investor) or the age of the oldest management company of the funds participating in the deal (if there is more than one investor).

* Size is the amount of capital under management of the fund at the time the deal was made (if there is one investor) or the amount of capital under management of the largest fund in the syndicate at the time the deal was made (if there is more than one investor, base category = Middle ( $75<=x<165$ in $\$$ million CDN)).

* Presence of foreign investor takes the value 1 if there is at least one foreign fund participating in the deal, 0 otherwise.

* Likelihood Ratio Chi-Square is significant ( $p$-value=0.000) with a degree of freedom of 24.

* The analyses employ, as alternate specifications, each of the following four measures of experience to ensure robustness of findings: the age of the management company of the fund, the number of funds the management company of the fund had raised, the number of entrepreneurial firms the management company of the fund had invested, and the number of exits the management company of the funds had experienced, at/by the time the deal was made. For syndicated deals, experience is measured by the level of experience of the most experienced fund in the syndicate. For each of the four measures of experience, a natural $\log$ and categorical transformations are also attempted (except for the number of exit variable, which produces a large number of missing values when transformed to the natural logarithm, i.e., there are a number of funds that have not attained a successful exit). For the sake of brevity, however, the specification using age of fund (as a natural number value) as an experience variable is reported. Results of specifications with other experience measures (and with/without the natural log/categorical transformations) do not differ from the above, and are available upon request. 
From these results, several observations are in order:

- Investee firms in high-tech sectors (Life Sciences, IT, other technologies) have relatively more investors than those in "Traditional" sectors, ( $p$-value $=0.000$ ), perhaps because investments in high-tech require venture capitalists to share specialized information to a greater degree (Bygrave, 1987, 1988; and Hopp and Rieder, 2006);

- Syndicates comprised primarily of government-affiliated funds (LSVCCs or Provincial VCCs) were associated with relatively fewer investors (pvalue $=0.001$ ). This is in line with the previous finding that first-round deals were less likely to be syndicated when the investor was a government-affiliated fund. Several explanations seem feasible. First, government-affiliated funds are typically young (Cumming and MacIntosh, 2006; 2002; 2001a) and therefore may not have well-established networks within the venture capital community which might facilitate finding syndication partners (see II-1-2-5). Also, governmentaffiliated funds may be willing to make early-stages investments that privatesector funds eschew (Cumming, 2006). Moreover, recall that eight large government-affiliated funds participated in 32 percent of all deals (see IV-2-3). They are typically large and have less need for additional sources of capital. These same eight funds may account for the significance of this variable. However, further investigation is necessary; 
- Syndicates comprised primarily of foreign funds tend to have relatively more investors. This makes sense as foreign funds need local investors as syndicate partners to mitigate problems of distance (costly monitoring, severe information asymmetry, unfamiliarity with the Canadian market, etc., Bruining, Verwaal, Lockett, Wright, and Manigart, 2006; Hopp and Rieder, 2006; Sorenson and Stuart, 2001; see II-2-2-2 and II-2-3-2). Foreign funds may also need more partners (local and non-local) to spread risk associated with distant investments (see II-2-2-1). Also, the network position of the foreign investor in its local community makes it easier to invite other foreign sources of capital to its deals;

- Again, region was a factor associated with the number of funds in a syndicate. The number of syndicate members was greater for deals in Ontario and Quebec than for those in other regions. Deals in British Columbia, the Prairie and Atlantic provinces, or "other" locations, had significantly fewer investors than those in Ontario (p-values of $0.057,0.001,0.001$, respectively). On the other hand, the number of investors involved in Quebec deals was not significantly different from that in Ontario deals. This suggests syndicates have a larger number of investors in regions with a relatively large number of large funds and a smaller number of investors in regions where large funds are scarce. This is contrary to what the bottleneck hypothesis predicts; however, recall that the analysis of Hypothesis 1 (V-2-1) found that large Canadian venture capital funds maintained a large number of companies in their portfolios. This implies that even large funds' 
capital may be spread thinly. If this is indeed the case, the results may mean that incumbent investors and entrepreneurs need to seek out capital from many (possibly large) funds - which is relatively more feasible in Quebec and Ontario than in British Columbia, the Prairies, and the Atlantic provinces.

- The level of experience (measured by the age of the oldest management company of the funds among incumbents) was positively associated with the number of investors in the syndicate $(\mathrm{p}$-value $=0.000)$. This is puzzling from the resourcebased view of syndication (see II-2-2-2) which predicts a greater need for syndication for less experienced venture capitalists. However, this result is consistent with the bottleneck hypothesis in that experienced funds (typically large funds) enter into a syndicate as a last resort - after the syndicate was already comprised of a large number of investors in order to amass capital; ${ }^{217}$

- All three measures of investee firm development were significant with expected signs $(\mathrm{p}$-value all $=0.000)$. Later financing rounds comprised significantly more investors than early rounds. The coefficient becomes larger as it moves from the second to the fifth rounds and thereafter, indicating an increased number of investors for later financing rounds. More investors seem to be necessary the greater the amount of venture capital disbursed and the longer the time since the investee first received its venture capital. All these findings are consistent with

${ }^{217}$ See Appendix IV and V: fund size and the level of fund experience are correlated and large funds are disproportionally parts of syndicates with five or more investors 
Hypothesis 4, that as the investee grows, it requires a greater amount of capital, which necessitates more investors in the syndicate;

- On the other hand, measures indicative of the size (capital availability) of the syndicate did not have coefficients with expected signs. It was expected that a syndicate comprised of small funds (that is, when the largest fund in the syndicate was "very small" or "small") would have relatively more investors because the capital availability of each fund would be low; and a syndicate with one or more "large" or "very large" funds would comprise fewer investors as it would not need to collect money from many small funds. However, the result was contrary to this expectation. Syndicates with one or more "large" or "very large" funds were more likely to have more investors ( $\mathrm{p}$-value $=0.001$ and 0.003 , respectively), and those comprised of "very small" funds were more likely to have fewer investors (pvalue=0.03);

- Moreover, it was expected that the presence of one or more foreign funds would reduce the syndicate size, as foreign funds' deeper pockets would cover the capital requirements of investees. Again, the result was the opposite. Syndicates with one or more foreign funds were more likely to have a larger number of investors $(\mathrm{p}$-value $=0.000){ }^{218}$

Therefore, these results are only partially supportive of Hypothesis 4. On the one hand, the empirical findings do show that more developed investee firms are associated with

\footnotetext{
${ }^{218}$ A specification that includes the interaction term between the level of the investee's development (the amount disbursed) and the investor's(s') size was also attempted; however, it was insignificant.
} 
relatively more investors. On the other hand, Hypothesis 4 predicted a greater number of investors in syndicates comprised of small funds - but the empirical results are contrary to this expectation: large (as well as foreign) funds tend to be involved in syndicates with relatively large numbers of funds.

This result might be explained if large (and foreign) funds join syndicates after syndicates with a large number of investors have already been formed. Supporting this, recall that in Canada syndicates often comprise many investors as early as the second round, ${ }^{219}$ and chi-square tests show that large funds and foreign funds participate disproportionately often in the third, fourth, fifth and later rounds (p-value $<0.01$; see Appendix V; see also next section). Also, because in Canada large funds' financial resources are spread so thinly, i.e., availability of capital is limited even for large funds, investors and entrepreneurs must amass capital from many funds, both large and small. Further investigation is, however, necessary at this point.

\section{1-3-2. US-Canada Comparisons}

This part of the analysis compared the number of investors in syndicates, across financing rounds, in Canada and the United States. ${ }^{220}$ The methodologies used to compare the two

\footnotetext{
${ }^{219}$ A small fund entry is significantly more likely at the second round.

${ }^{220}$ As discussed in Chapter IV, the United States data used here were extracted from the MoneyTree Report (which, in turn, is sourced from Thomson-Reuters), which provides a list of all the venture capital deals in the United States during the first quarter of 2010. The data include the number of investors, the round number, the stage of the investment (seed, start-up, expansion, etc.) and the amount of venture capital
} 
countries included standard t-tests and Poisson regressions. For the t-tests, deals were categorized into four groups based on the amount invested (less than or equal to five million, greater than five million and less than or equal to ten million, greater than ten million and less than or equal to 20 million, greater than 20 million). ${ }^{221}$ The average number of investors in each deal was then compared in Canada and the United States for each "size of investment" category. In the American data, the majority of first round investments were early stage and the majority of later round investments were expansion stage. Thus, the analysis of first round deals compared the number of investors in earlystage investments only, and the analysis of later round deals compared those in expansion-stage only, in Canada and in the United States.

In the Poisson regressions, the dependent variable was the number of investors that participated in the deal. Explanatory variables comprised a binary variable corresponding to the country in which the deal took place (Canada $=0.0, \mathrm{US}=1.0$ ); and the interaction term between the country dummy and the amount invested in the deal. The results are presented in Table V-9 (t-tests) and V-10 (Poisson regressions).

invested in the round. Canadian data were extracted from Thomson-Reuters, the database from which the data for the Canadian analyses was obtained.

${ }^{221}$ US dollars were converted to Canadian dollars using the Bank of Canada's nominal exchange rate as of March 31 ${ }^{\text {st }}, 2009$. 
Table V-9: US-Canada Comparison of Number of Investors per Deal

\begin{tabular}{|c|c|c|c|c|c|c|c|c|}
\hline & Canada & & & U.S. & & & t-test & \\
\hline $\begin{array}{l}\text { Size of } \\
\text { Investments } \\
(\$ 000)\end{array}$ & $\begin{array}{l}\text { Mean } \\
\text { Number of } \\
\text { Investors }\end{array}$ & $\mathbf{N}$ & S.E. & $\begin{array}{l}\text { Mean } \\
\text { Number of } \\
\text { Investors }\end{array}$ & $\mathbf{N}$ & S.E. & $\begin{array}{l}\mathrm{t}- \\
\text { value }\end{array}$ & $\begin{array}{l}\text { p-value } \\
\text { (one- } \\
\text { tailed) }\end{array}$ \\
\hline \multicolumn{9}{|c|}{ First Round Investments } \\
\hline$x \leq 5,000$ & 1.84 & 332 & 0.054 & 1.61 & 95 & 0.103 & 1.98 & 0.024 \\
\hline $5,000<x \leq 10,000$ & 2.89 & 44 & 0.170 & 1.96 & 23 & 0.172 & 3.85 & 0.000 \\
\hline $10,000<x \leq 20,000$ & 4.00 & 16 & 0.354 & 2.53 & 15 & 0.376 & 2.85 & 0.004 \\
\hline$x>20,000$ & 4.67 & 6 & 1.022 & 2.14 & 7 & 0.508 & 2.22 & 0.024 \\
\hline All Investments & 2.08 & 398 & 0.061 & 1.79 & 140 & 0.092 & 2.63 & 0.004 \\
\hline \multicolumn{9}{|c|}{ Later Round Investments } \\
\hline$x \leq 5,000$ & 1.68 & 114 & 0.099 & 1.54 & 54 & 0.105 & 0.97 & 0.167 \\
\hline $5,000<x \leq 10,000$ & 3.46 & 26 & 0.334 & 2.21 & 29 & 0.201 & 3.21 & 0.001 \\
\hline $10,000<x \leq 20,000$ & 5.04 & 23 & 0.497 & 2.79 & 28 & 0.220 & 4.14 & 0.000 \\
\hline$x>20,000$ & 5.67 & 21 & 0.611 & 3.50 & 16 & 0.456 & 2.85 & 0.004 \\
\hline All Investments & 2.80 & 184 & 0.166 & 2.21 & 127 & 0.115 & 2.92 & 0.002 \\
\hline
\end{tabular}


Table V-10: Poisson Regressions on Number of Investors

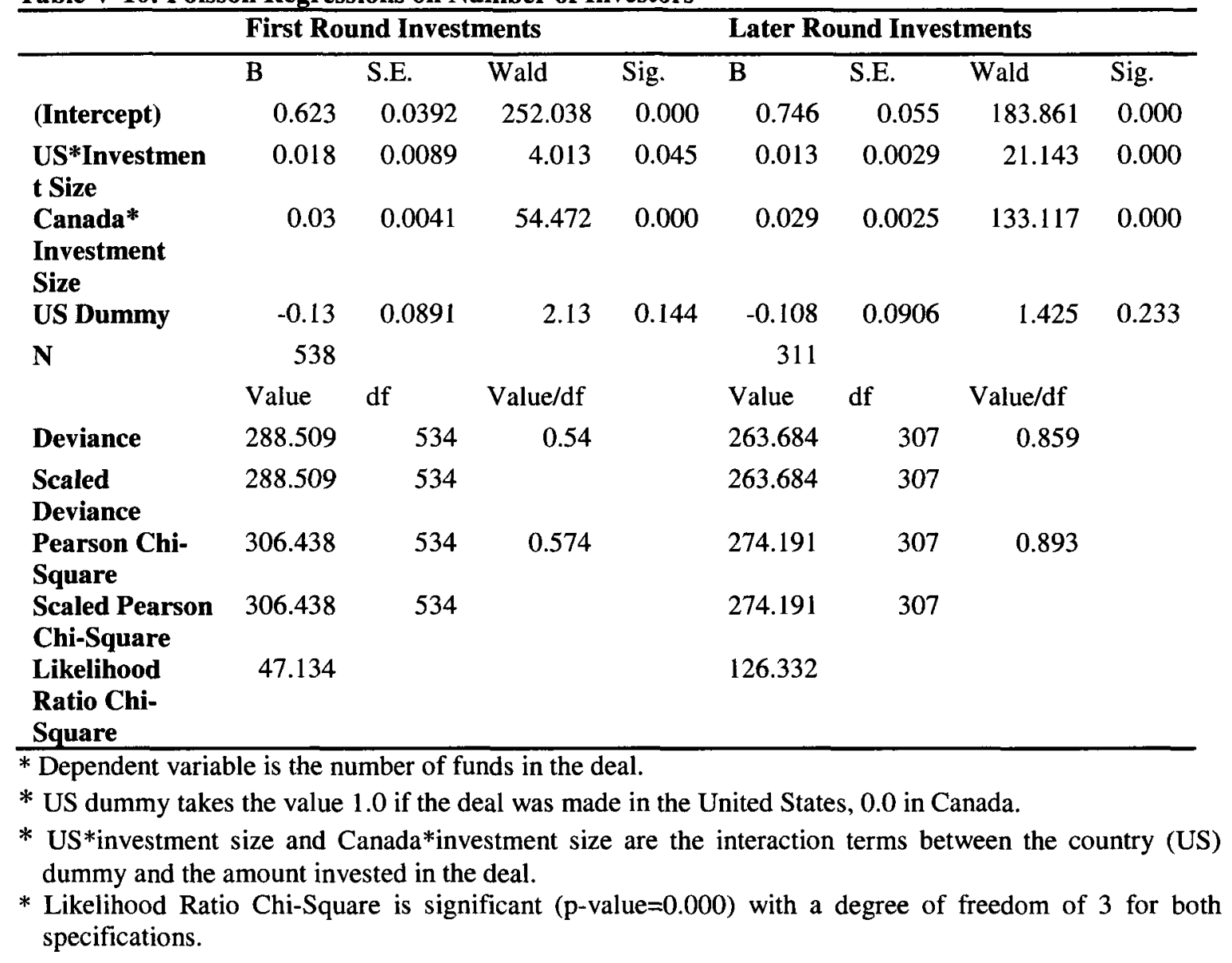

The t-tests show that the average number of investors was significantly greater for the Canadian deals than for those of the American counterparts across all deal size categories. This was true for both the initial and later investment rounds. The Poisson regressions confirms this result and shows that, while investment size was positively correlated with the number of investors in both countries, the number of investors per dollar invested was greater for Canada. For first round investments, the difference in coefficients between the two interaction terms (US*investment size versus 
Canada*investment size) was insignificant $(\mathrm{t}$-value $=1.236$, $\mathrm{p}$-value $=0.110)$, but for the later rounds, it was significant at $\mathrm{p}$-value $=0.000(\mathrm{t}-\mathrm{value}=4.179){ }^{222}$

These results are consistent with Hypothesis 4 in that they reveal relatively more investors involved in syndicates when investors are small and when investee firms require large capital infusions as they grow (recall Figure V-3 in V-2-1-2: Canadian funds are smaller than American funds). Results also support the bottleneck hypothesis prediction that syndication is relatively more likely in a venture capital community comprised of few large funds and many small funds. ${ }^{223}$

\section{1-3-3. Summary of Results of Hypothesis 4}

The results of testing Hypothesis 4 are summarized as follows:

- The number of syndicate members was greater for deals in Ontario and Quebec than for those in British Columbia, the Prairies, and the Atlantic provinces. This may be an indication that because large funds' financial resources are spread so thinly in Canada, investors and entrepreneurs must seek capital from many large

\footnotetext{
${ }^{222}$ This probably reflects: (1) the larger number of observations for greater investment size categories for later financing rounds; (2) for American data, the impact of investment size is smaller for later round investments than for first round investments (probably due to less uncertainty associated with later round investments (De Clercq and Dimov, 2004; Lockett and Wright, 1999, 2001; Hopp and Rieder, 2006; see II2-2-2 and II-2-3-2)), while for Canadian data, the impact of investment size is about the same between first and later round investments.

${ }^{223}$ This part of the analysis is confined to the two cases discussed above (first round investments in reportedly "early" stage firms and later round investments in "expansion" stage firms). Of course, other combinations (such as fourth round investments in "seed" stage firms) are feasible; however, there was insufficient data to explore other combinations of round and stage.
} 
(and small) funds. This is relatively more feasible in Quebec and Ontario than it is in other regions;

- The number of investors increased: (1) as financing moved from the first to later rounds; (2) when the investee firms required larger amounts of capital; and, (3) as time elapsed since investees' receipt of first venture capital investment. These results are consistent with Hypothesis 4 that growing investee firms require greater amounts of capital which necessitates adding to the number of investors in the syndicate;

- Syndicates with one or more large funds were more likely to have more investors and those comprised of very small funds were more likely to have fewer investors. Syndicates with foreign funds were also more likely to have more investors. These results are not consistent with Hypothesis 4. These results may mean that large (and foreign) funds are added as a last resort; that is, they enter a syndicate later, after the syndicate has recruited several investors in order to amass capital from many small funds. Support for this explanation stems from chi-square tests that showed that large funds and foreign funds participated disproportionately in later rounds (see Appendix V). Also, if in Canada large funds' financial resources are spread thinly, availability of capital may be limited even for large funds, and therefore investors and entrepreneurs must amass capital from many large (and small) funds. Further investigation is necessary at this point; 
- The number of investors involved in an investment was significantly higher for Canadian deals than for American deals. The number of investors and the amount invested were significantly positively related for all deals, but the impact of a dollar increase on investment size was greater for Canadian deals. These results are consistent with Hypothesis 4, as well as with the prediction of the bottleneck hypothesis: more syndication activity exists in a venture capital community comprised of few large funds and many small funds;

- Therefore, Hypothesis 4 was partially supported: it was supported by the evidence indicating that more investors were added as firms developed; that the number of investors per deal was significantly larger in Canada than in the United States; and, that the impact of a dollar increase on investment size was significantly greater for Canadian deals. It was not supported by the evidence that found that a higher number of investors were associated with syndicates with large funds.

\section{1-4. Hypothesis $5 a$}

Hypothesis 5a: The smaller the incumbent investor(s), the more likely that a new investor added to the syndicate is larger than the incumbent $(s)$, especially at later stages of financing (as the investee firm grows).

This hypothesis reflects the expectation that as entrepreneurial firms grow, they require progressively greater amounts of financing, such that the ownership team (founders and incumbent investors) have reason to look to larger funds as a first choice of syndicate 
partner, with smaller funds being especially likely to seek larger partners. As a second or alternative - strategy, incumbent early-stage investors might resort to enlarging the syndicate by seeking out a large number of small investors; however, this may be suboptimal given the difficulties associated with managing large investor syndicates (see II2-5-4). Early investors would need to syndicate with larger, or more, investors to procure sufficient financing for growing investee firms but this need would be less acute for larger incumbent investors. Essentially, then, this hypothesis predicts that the size of the investor funds that enter a syndicate increases: (1) when the incumbent funds are small; and, (2) from round to round as the investee firms grow. Two different statistical analyses, a pairwise logistic regression and a multinomial logistic regression, were carried out to test Hypothesis 5a. The following sub-subsections introduce the two models (1-4-1) and then present the results and discuss the findings (1-4-2).

\section{1-4-1. Pairwise and Multinomial Logistic Regression Models}

The first test is a pairwise logistic regression model of the probability of adding large investors. Here, the logistic regression model is similar to model 3 for Hypotheses 2 and 3 but with a different dependent variable. Following Lerner (1994b), a pair of logistic regression models were run for each of $t, t \geq 2$ (second and subsequent rounds of financing) using the same independent and controlling variables but different dependent variables. In the first variation, the dependent variable is a binary variable corresponding 
to whether (or not) a new large investor is added to the syndicate in a particular round; in the second variation, the dependent variable is a binary variable corresponding to whether (or not) a new small investor is added to the syndicate.

$$
\operatorname{logit}\left[\pi\left(A D D ?_{, t, t}\right)\right]=\alpha_{0}+\alpha_{I} * S I Z E_{l / k, t}+\alpha_{2} * S T A G E_{j, t}+\tilde{\alpha}_{3} * \tilde{C}_{\text {ontrol }},
$$

where: $\operatorname{logit}\left[\pi\left(A D D ?_{, t}\right)\right]=\log \left(\frac{\pi\left(A D D ?_{\jmath, t}\right)}{1-\pi\left(A D D ?_{, t}\right)}\right)$, where $\pi\left(A D D ?_{,, l}\right)=$ probability of new investor entrance.

$S I Z E_{l / k, t}=\quad$ Size measures of incumbent venture capital fund $i$ or syndicate $k$ comprised of incumbent funds at the time of $t^{\text {th }}$ financing round.

$S T A G E_{j, t}=\quad$ Measures for the level of development of investee firm $j$ at $t^{t h}$ financing round.

$\tilde{C}$ ontrol $t_{t} \quad \mathrm{~A}$ vector of variables controlling for the characteristics of the deal, as well as venture capital fund $i$ (or syndicate $k$ ) and entrepreneurial firm $j$ at $t^{\text {th }}$ financing round.

The dependent variable for one of the pair of models, "Large_Added", is $\operatorname{logit}\left[\pi\left(A D D ?_{,, t, \text { large }}\right)\right]$ and the other, "Small_Added", is $\operatorname{logit}\left[\pi\left(A D D ?_{, t, \text { small }}\right)\right]$.

$\pi(A D D ?)_{j, t, \text { large }}$ takes the value 1.0 when: (1) the incumbent venture capitalists add a new investor to their syndicate at time $t$; and (2) the entrant is larger than the incumbents. It is 0.0 when: (1) the incumbent venture capitalists do not add a new investor at time $t$; or (2) they do add one but the entrant is smaller than or equal to the incumbents.

$\pi(A D D ?)_{j, t, \text { small }}$ takes value 1.0 when: (1) the incumbent venture capitalists adds a new investor to their syndicate at time $t$; and (2) the entrant is smaller than or the same size as the incumbents. It is 0.0 when: (1) the incumbent venture capitalists do not add a new investor at time $t$; or (2) they do add one but the entrant is larger than the incumbents. 
An alternative approach to testing Hypothesis 5a is to use a multinomial logistic regression framework. In this instance, model 5 is again employed but the dependent variable is redefined as a three-level categorical variable coded as 0.0 when no new investor is added to syndicate $k$ at the $t^{\text {th }}$ financing round; 1.0 when a new venture capitalist is added and the entrant is smaller than or the same size as the largest of the incumbents in the syndicate; and 2.0 when a new venture capitalist is added the entrant is larger than the largest of the incumbents (the reference category is 1.0 ). The multinomial logit model simultaneously refers to all pairs and describes: (1) the odds of an entrance of a new investor that is larger than the incumbent(s) against the odds of an entrance of a new investor that is smaller than (or equal to) the incumbent(s); (2) the odds of an entrance of a new investor that is smaller than (or equal to) the incumbent(s) against the odds of an absence of a new investor; (3) the odds of an entrance of a new investor that is larger than the incumbent(s) against the odds of an absence of a new investor. ${ }^{224}$

Hypothesis 5a predicts that capital constraints of the incumbent venture capitalists, induced by small fund sizes, call for further syndication with larger less financially constrained funds. It therefore expects a significant negative relationship between incumbent venture capital fund size and the probability of one or more large investor's entry.

The next section presents and discusses the results of the estimation of the pairwise regression model and of the multinomial logistic model.

${ }^{224}$ The third pair is redundant (Agresti, 1996). 
1-4-2. Results: Pairwise and Multinomial Logistic Regression Models

The results of the pairwise logistic regression are presented in Table V-11, and those of the multinomial logistic regression are in Table V-12. Since the two models generated similar results, the findings are discussed mainly based on the pairwise logistic regression analysis (that is, unless specified otherwise, the discussion is based on the pairwise regression analysis). 
Table V-11: Pairwise Logistic Regression on Probability of Large (Small) Fund Entry (Later Rounds)

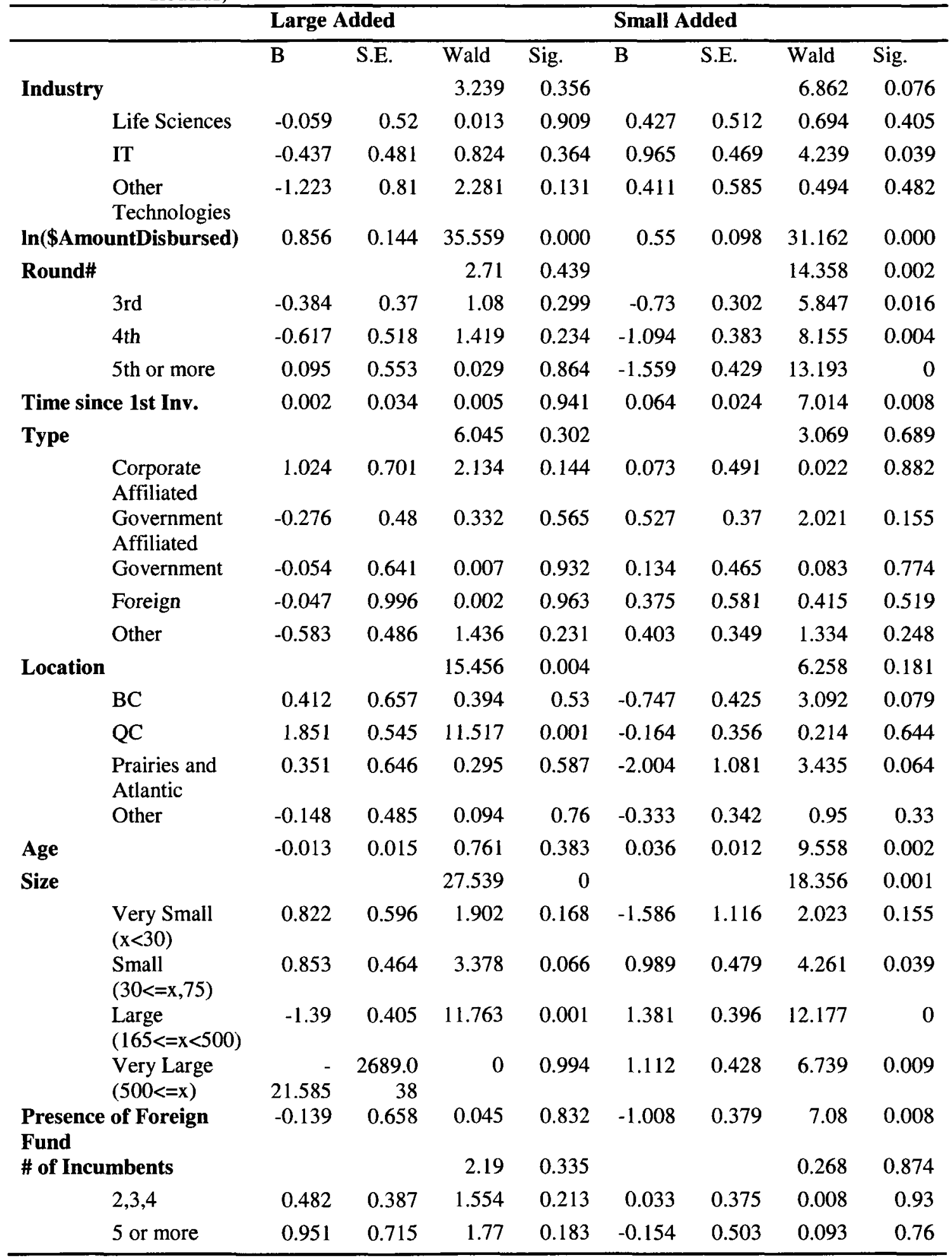




\begin{tabular}{|c|c|c|c|c|}
\hline \multirow[t]{8}{*}{ Constant } & -1.936 & 0.013 & $0.724 \quad 26.308$ & 0 \\
\hline & $\mathbf{N}$ & 599 & $\mathbf{N}$ & 599 \\
\hline & $\begin{array}{l}\text { Not added, or entrant } \\
\text { smaller than or same } \\
\text { size as incumbent }\end{array}$ & 504 & $\begin{array}{l}\text { Not added, or entrant } \\
\text { larger than incumbent }\end{array}$ & 444 \\
\hline & $\begin{array}{l}\text { Entrant larger than } \\
\text { incumbent }\end{array}$ & 95 & $\begin{array}{l}\text { Entrant smaller than } \\
\text { or same size as } \\
\text { incumbent }\end{array}$ & 155 \\
\hline & -2 Log likelihood & 328.200 & -2 Log likelihood & 521.736 \\
\hline & p-value, model & 0 & p-value, model & 0 \\
\hline & Cox \& Snell R Square & 0.279 & Cox \& Snell R Square & 0.239 \\
\hline & Nagelkerke R Square & 0.478 & Nagelkerke R Square & 0.35 \\
\hline
\end{tabular}

* Dependent variable for "Large Added" specification is a binary variable equal to 1 when: (1) the incumbent venture capitalists add a new investor to their syndicate at time $t$; and (2) the entrant is larger than the incumbents. It is 0.0 when: (1) the incumbent venture capitalists do not add a new investor at time $t$; or (2) they do, but the entrant is smaller than or the same size as the incumbents. Dependent variable for "Small Added" specification is a binary variable equal to 1 when: (1) the incumbent venture capitalists add a new investor to their syndicate at time $t$; and (2) the entrant is smaller than or the same size as the incumbents. It is 0.0 when: (1) the incumbent venture capitalists do not add a new investor at time $t$; or (2) they do but the entrant is larger than the incumbents.

* Industry is the sector in which the investee company operates (base category $=$ Traditional).

* $\ln (\$$ AmountDisbursed) is the natural logarithm of the dollar amount of the venture capital disbursed to the investee at the financing round (in million $\mathrm{CDN}$ ).

* Round\# is the financing round number (base category $=2^{\text {nd }}$ round).

* Time since 1 st Inv. Is the number of days since the $1^{\text {st }}$ venture capital investment to the current round (in 100 days).

* Type is the type of tfund (if there is one incumbent investor) or the type of the funds that form the majority of funds in the incumbent syndicate (if there are more than one incumbent investors, base category $=$ private independent).

* Location is the province in which the fund and the investee are located (if there is one incumbent investor), or the province in which the funds that form the majority of funds in the incumbent syndicate and the investee are located (if there are more than one incumbent investors, base category $=$ Ontario).

* Age is the age of the management company of the fund (if there is one incumbent investor) or the age of the oldest management company of the funds participating in the deal (if there are more than one incumbent investors).

* Size is the amount of capital under management of the fund (if there is one incumbent investor) or the amount of capital under management of the largest fund in the incumbent syndicate at the time the deal was made (if there are more than one incumbent investosr, base category = Middle $(75<=x<165$ in $\$$ million CDN)).

* Presence of foreign investor takes the value 1 if there is at least one foreign fund in the incumbent syndicate, 0 otherwise.

* \# of Incumbents is the number of incumbent funds in the deal at the time the deal was made (base category $=$ one).

* The analyses employ, as alternate specifications, each of the following four measures of experience to ensure robustness of findings: the age of the management company of the fund, the number of funds the management company of the fund had raised, the number of entrepreneurial firms the management company of the fund had invested, and the number of exits the management company of the funds had experienced, at/by the time the deal was made. For deals with more than one incumbent funds, experience is measured by the level of experience of the most experienced fund in the incumbent 
syndicate. For each of the four measures of experience, a natural log and categorical transformations are also attempted (except for the number of exit variable, which produces a large number of missing values when transformed to the natural logarithm, i.e., there are a number of funds that have not attained a successful exit). For the sake of brevity, however, the specification using age of fund (as a natural number value) as an experience variable is reported. Results of specifications with other experience measures (and with/without the natural log/categorical transformations) do not differ from the above, and are available upon request. 
Table V-12: Multinomial Logistic Regression on Probability of Large Fund Entry, Small Fund Entry, and No Entry (Later Rounds)

\begin{tabular}{|c|c|c|c|c|c|c|c|c|c|}
\hline & \multicolumn{4}{|c|}{ Large v/s Small (base) } & \multicolumn{4}{|c|}{ No Entry v/s Small (base) } \\
\hline & & B & S.E. & Wald & Sig. & B & S.E. & Wald & Sig. \\
\hline \multicolumn{2}{|l|}{ Intercept } & 1.199 & 0.972 & 1.521 & 0.217 & 3.28 & 0.759 & 18.686 & 0 \\
\hline \multicolumn{2}{|c|}{ In(\$AmountDisbursed) } & 0.343 & 0.162 & 4.495 & 0.034 & -0.749 & 0.109 & 47.081 & 0 \\
\hline \multicolumn{2}{|c|}{ Time since 1st Inv. } & -0.045 & 0.037 & 1.428 & 0.232 & -0.063 & 0.025 & 6.126 & 0.013 \\
\hline \multicolumn{2}{|l|}{ Age } & -0.038 & 0.017 & 4.725 & 0.03 & -0.037 & 0.012 & 8.775 & 0.003 \\
\hline \multirow[t]{3}{*}{ Industry } & Life Sciences & -0.48 & 0.686 & 0.49 & 0.484 & -0.454 & 0.531 & 0.73 & 0.393 \\
\hline & IT & -1.217 & 0.632 & 3.707 & 0.054 & -0.938 & 0.485 & 3.733 & 0.053 \\
\hline & $\begin{array}{l}\text { Other } \\
\text { Technologies }\end{array}$ & -1.537 & 0.937 & 2.691 & 0.101 & -0.205 & 0.604 & 0.115 & 0.735 \\
\hline \multirow[t]{3}{*}{ Round\# } & $3 \mathrm{rd}$ & 0.26 & 0.429 & 0.368 & 0.544 & 0.799 & 0.317 & 6.354 & 0.012 \\
\hline & 4 th & 0.307 & 0.6 & 0.262 & 0.609 & 1.235 & 0.398 & 9.633 & 0.002 \\
\hline & 5 th or more & 1.278 & 0.645 & 3.924 & 0.048 & 1.604 & 0.446 & 12.944 & 0 \\
\hline \multirow[t]{5}{*}{ Type } & $\begin{array}{l}\text { Corporate } \\
\text { Affiliated }\end{array}$ & 0.877 & 0.791 & 1.231 & 0.267 & -0.135 & 0.515 & 0.069 & 0.793 \\
\hline & $\begin{array}{l}\text { Government } \\
\text { Affiliated }\end{array}$ & -0.571 & 0.543 & 1.103 & 0.294 & -0.341 & 0.386 & 0.781 & 0.377 \\
\hline & Government & -0.198 & 0.718 & 0.076 & 0.782 & -0.082 & 0.495 & 0.028 & 0.868 \\
\hline & Foreign & -0.323 & 1.071 & 0.091 & 0.763 & -0.31 & 0.598 & 0.268 & 0.605 \\
\hline & Other & -0.702 & 0.537 & 1.71 & 0.191 & -0.219 & 0.368 & 0.354 & 0.552 \\
\hline \multirow[t]{4}{*}{ Location } & $\mathrm{BC}$ & 0.82 & 0.706 & 1.348 & 0.246 & 0.682 & 0.446 & 2.335 & 0.126 \\
\hline & $\mathrm{QC}$ & 1.69 & 0.594 & 8.108 & 0.004 & -0.241 & 0.379 & 0.404 & 0.525 \\
\hline & $\begin{array}{l}\text { Prairies and } \\
\text { Atlantic }\end{array}$ & 1.879 & 1.184 & 2.517 & 0.113 & 1.924 & 1.097 & 3.074 & 0.08 \\
\hline & Other & 0.086 & 0.533 & 0.026 & 0.871 & 0.249 & 0.358 & 0.485 & 0.486 \\
\hline \multirow[t]{4}{*}{ Size } & $\begin{array}{l}\text { Very Small } \\
(\mathrm{x}<30)\end{array}$ & 2.049 & 1.184 & 2.998 & 0.083 & 1.29 & 1.127 & 1.311 & 0.252 \\
\hline & $\begin{array}{l}\text { Small } \\
(30<=x, 75)\end{array}$ & 0.003 & 0.571 & 0 & 0.996 & -1.245 & 0.514 & 5.879 & 0.015 \\
\hline & $\begin{array}{l}\text { Large } \\
(165<=x<500)\end{array}$ & -2.006 & 0.49 & 16.78 & 0 & -1.032 & 0.42 & 6.026 & 0.014 \\
\hline & $\begin{array}{l}\text { Very Large } \\
(500<=x)\end{array}$ & 24.335 & 0 & 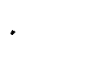 & & -0.287 & 0.461 & 0.388 & 0.533 \\
\hline \multicolumn{2}{|c|}{ Presence of Foreign Fund } & 0.598 & 0.708 & 0.715 & 0.398 & 1.141 & 0.396 & 8.309 & 0.004 \\
\hline \multirow{2}{*}{$\begin{array}{l}\text { \# of } \\
\text { Incumben }\end{array}$} & $2,3,4$ & 0.338 & 0.483 & 0.489 & 0.484 & -0.158 & 0.394 & 0.16 & 0.689 \\
\hline & 5 or more & 0.887 & 0.798 & 1.237 & 0.266 & 0.028 & 0.531 & 0.003 & 0.957 \\
\hline \multicolumn{2}{|l|}{$\mathbf{N}$} & 599 & & & & & & & \\
\hline \multicolumn{2}{|c|}{ Not Added } & 349 & & & & & & & \\
\hline \multicolumn{2}{|c|}{ Small Added } & 155 & & & & & & & \\
\hline \multicolumn{2}{|c|}{ Large Added } & 95 & & & & & & & \\
\hline \multicolumn{2}{|c|}{-2 Log Likelihood } & 779.767 & & & & & & & \\
\hline
\end{tabular}




\begin{tabular}{lr}
\hline Chi-Square & 366.218 \\
df & 50 \\
Sig. & 0.000 \\
Cox and Snell & 0.457 \\
Nagelkerke & 0.537 \\
McFadden & 0.32
\end{tabular}

Dependent variable is a three-level categorical variable coded as 0.0 when no new investor is added to syndicate $k$ at the $t^{\text {th }}$ financing round; 1.0 when a new venture capitalist is added and the size of the new investor is smaller than or equal to that of the incumbent venture capitalists; and 2.0 when a new venture capitalist is added and the new investor is larger than the incumbent venture capitalists. The reference category is 1.0 .

* Independent variables are the same as those in the logistic regression above. 
From estimation of these models, the following observations are noted.

- There was no significant difference in the odds ratio of a large investor entry among investee firms in different industry sectors. As for the odds ratio of a smaller or equal-sized investor entrance, however, the IT sector was significantly higher ( $p$-value $=0.039$ ) than the traditional sector (the base category). The multinomial regression model confirmed this point;

- The association between the likelihood of a large fund entry (as well as that of a small fund entry) and the type of the incumbent fund/funds that predominated in the syndicate was insignificant ( $\mathrm{p}$-value $=0.302$ for "Large-Added" and 0.689 for "Small_Added" model). However, the location of the deal showed interesting results, which appeared to reflect the industry structure of the various Canadian regions. A fund(s) that was larger than the largest fund in the incumbent syndicate was significantly ( $p$-value $=0.001$ ) more likely to enter the syndicate when the majority of the incumbent funds and the investee firm were located in Quebec. Recall that Quebec is the province in which most large funds are located, thus finding a large fund as an additional syndicate partner is relatively easier in Quebec;

- On the other hand, the fund(s) that was smaller than or equal to the largest fund in the incumbent syndicate was significantly less likely to enter the syndicate when the deal was located in British Columbia, the Prairies, or the Atlantic provinces (p-value $=0.079$ for British Columbia, 0.064 for the Prairies and the Atlantic 
provinces). The multinomial logistic regression revealed that deals in the Prairies and the Atlantic provinces: (1) were marginally significantly more likely to add a fund larger than the incumbents, as opposed to a fund smaller than the incumbent (p-value $=0.113) ;(2)$ were more likely not to add a new fund as opposed to adding a smaller fund ( $\mathrm{p}$-value $=0.08$ ). Thus, it seems that deals in the Prairies and the Atlantic provinces are less likely to add a fund of any size, arguably reflecting the industry structure (a smaller number of venture capital funds especially large funds - existing in the Prairies), but they tend to choose a larger fund when they do add a new investor;

- The age of the incumbent fund management company (the oldest management company in the syndicate) was significantly ( $\mathrm{p}$-value $=0.002$ ) positively related to the probability of an entry of a smaller or equal-sized fund but was not related to the probability of a large fund entry. Smaller funds were more likely to be brought into later round financings by experienced organizations. Assuming that smaller funds are less experienced (see Appendix IV), this is consistent with Lerner's (1994a) "second opinion" hypothesis that contends that deals initiated by inexperienced venture capitalists are less attractive to other venture capitalists (their judgments as to the investee firm's prospects are viewed as less trustworthy by, in particular, experienced venture capitalists);

- The amount of venture capital disbursed (a measure of the investee firm's level of development) had a significant and positive impact on both the odds ratio of a 
larger fund entrance and a smaller-or-same-sized fund entrance ( $p$-value $=0.000$ for both models), with the coefficient greater for the large fund entrance. The Wald chi-square statistic for testing the null hypothesis that the two coefficients are the same (3.09) had an associated p-value of 0.079. ${ }^{225}$ Confirming this point, the multinomial logistic regression revealed that the greater the amount of venture capital required, the more likely it was that a larger fund (as opposed to a smalleror-equal-sized-fund(s)) entered the syndicate $(\mathrm{p}$-value $=0.034)$. Thus, a larger fund is significantly more likely to enter the syndicate when the investee requires a greater amount of capital. This is consistent with Hypothesis 5a;

- Smaller-or-equal-sized-funds were significantly more likely to enter at the second round $^{226}$ and the probability of smaller-or-equal-sized-fund entrances decreases as the financing round number grows (smaller funds become less attractive syndicate partners as investee firms grow and require larger amounts of capital). Round number was not significant in the "Large_Added" model, however, the multinomial regression revealed that a larger fund (as opposed to a smaller fund) was more likely to enter at the fifth round or later $(\mathrm{p}$-value $=0.048)$. These findings are consistent with Hypothesis 5a;

${ }^{225}$ Wald chi-square statistic $=\frac{\left(b_{\text {large }}-b_{\text {small }}\right)^{2}}{\left[\text { s.e. }\left(b_{\text {large }}\right)\right]^{2}+\left[\text { s.e. }\left(b_{\text {small }}\right)\right]^{2}}=3.09$.

${ }^{226}$ The second round was the base category; p-values of the third, fourth, and fifth and later rounds were, respectively, 0.016, 0.004, 0.000), 
- The longer the time since the investee first received a venture capital investment, the more likely it was that a smaller fund entered ( $p$-value $=0.008$ ). This is not consistent with Hypothesis 5a but may simply reflect the pervasively high level of syndication;

- Compared to mid-sized syndicates (the base category):

○ "large-fund" syndicates were significantly less likely to add a larger fund and more likely to add a smaller or an equal-sized fund ( $p$-value $=0.001,0.000$, respectively); and,

○ "very large" syndicates were significantly ( $\mathrm{p}$-value $=0.009$ ) more likely to add a smaller or an equal-sized fund. ${ }^{227,228}$ Compared to "large" (or "very large") syndicates, "very small" syndicates were more likely to add a larger fund and less likely to add a smaller fund. Moreover, the multinomial regression showed that "very small syndicates were more likely to add a larger fund (as opposed to an equal-sized fund), as compared to mid-sized syndicates (pvalue $=0.083$ ). These results are consistent with Hypothesis $5 \mathrm{a}^{229,230}$

\footnotetext{
${ }^{227}$ By definition, "very large" funds are unable to add a fund that is greater in size than they are, resulting in an unusually large coefficient and a standard error.

${ }^{228}$ The reason why very large and large syndicates add a small fund is beyond the scope of this study but an area for future study.

${ }_{229}$ A specification that includes the interaction term between the level of the investee's development (the amount disbursed) and the investor's(s') size was also attempted for both "Large Added" and "Small Added" models; however, it was insignificant.

${ }^{230}$ Table V-11 presents the estimation of the full model. In addition, a base model was estimated, one which omits the size-related variables, namely, the size of fund(s) and the presence of foreign fund. The collective addition of the block of variables that seek to measure size, improved the goodness of fit statistically significant degree (p-value, block=0.000), for both "Large Added" and "Small Added" models.
} 
- "Small-fund" syndicates seem likely to add a fund of any size, as both the odds ratios of a large fund entry and a small or equal-sized fund entry are significantly higher for small syndicates ( $p$-value $=0.066,0.039$, respectively) than middle-sized syndicates (the base category). The difference in coefficients is insignificant (Wald chi-square $=0.042$, -value $=0.838$ ). Confirming this point, the multinomial regression showed that "small" syndicates were not particularly more likely to add a larger fund, as opposed to adding a smaller fund ( $\mathrm{p}$-value $=0.996$ ), but they were significantly more likely to add a smaller fund, instead of not adding any fund ( $\mathrm{p}$-value $=0.015$ ). This is consistent with Hypothesis 2 .

However, the above results on the effect of the size of a syndicate should be viewed with a caveat. Small funds have a relatively larger number of funds that are larger than they are as potential syndicate partners, and large funds have a relatively high number of funds that are smaller than they are as potential syndicate partners. The results obtained here may simply be a reflection of this.

- There was no significant ( $\mathrm{p}$-value $=0.832$ ) difference in the probability of a large fund entry between incumbent syndicates with one (or more) foreign investor and those without, while incumbent syndicates with a foreign investor(s) were less likely to add a smaller or equal-sized fund ( $p$-value $=0.008)$. While these results are not exactly what Hypothesis 5a predicts, the multinomial logistic regression revealed: 
- no significant difference in the probability of a larger fund entry (as opposed to a smaller fund entry) between syndicates with one (or more) foreign fund(s) and those without;

o the probability of no new fund entry (instead of a smaller fund entry) being significantly higher for syndicates with a foreign fund. Thus, it seems that incumbent syndicates with one (or more) foreign investor(s) are not interested in adding either large or small investors, likely because of the foreign fund's typically deeper pockets. This is consistent with Hypothesis 5a (and Hypothesis 2).

\section{1-4-3. Summary of Results of Hypothesis 5 a}

The results of testing Hypothesis 5a are summarized as follows:

- Quebec deals were more likely to add larger investor(s), arguably a reflection of the industry structure;

- Larger funds were significantly more likely to join a syndicate when the investee required greater amounts of capital. The probability that a smaller fund joined a deal decreased with later financing rounds while larger funds were more likely to enter a deal in the fifth round or later. These results are consistent with Hypothesis 5a; 
- The results regarding the impact of size on a new investor entry were consistent with Hypothesis 5a, but should be viewed with a caveat:

○ A "very small" incumbent investor(s) was more likely to add a larger investor(s) and less likely to add an equal-sized investor(s);

○ "Large" incumbent funds were significantly less likely to add a larger fund and more likely to add a smaller or equal-sized fund;

- "Very large" funds were significantly more likely to add a smaller or equalsized fund; and,Incumbent syndicates with one (or more) foreign investor(s) did not appear to be interested in either large or small fund entry, consistent with Hypothesis 5a.

\section{2-5. Hypothesis $5 b$}

Hypothesis 5b: When incumbent investors are small and are part of a community comprising relatively few large funds, foreign venture capital funds are more likely to participate at later stages of financing (as the investee firms grow).

The testing of Hypothesis $5 \mathrm{~b}$ parallels that of Hypothesis 5a (pairwise logistic regression and multinomial logistic regression), with one change. As was done for Hypothesis 5a, deals were again divided into three groups; however, the basis of the grouping used to test Hypothesis $5 \mathrm{~b}$ was whether or not the entrant was a foreign investor. Hypothesis $5 \mathrm{~b}$ predicts the size of the incumbents to be smaller on average for the financing rounds in which a foreign entrant is involved, and the probability of a foreign fund entry to be 
higher as the investee firm grows. Because this thesis is concerned with the possibility that the Canadian sector is "bottlenecked", a "foreign fund" is defined as a venture capital fund that is not based in Canada. The majority, but not all, such funds are based in the United States.

The following sub-subsections introduce the two models (1-5-1) and present the results and discuss the findings (1-5-2).

\section{1-5-1. Pairwise and Multinomial Logistic Regression Models}

Both the pairwise and multinomial logistic regression frameworks employ model 5 , the model that was used for Hypothesis 5a, but with different dependent variables. In this instance, the dependent variable corresponds to whether a new investor entry to a syndicate is a foreign venture capital firm or a domestic firm. For the pairwise logistic regressions, the dependent variable for one of the pair of models is "Foreign_Added", and the other is "Domestic_Added". The dependent variable for the "Foreign_Added" model is set to 1.0 when the incumbent syndicate adds a new investor to their syndicate at time $t$ and the entrant is foreign. It is set to 0.0 when the incumbent syndicate does not add a new investor at time $t$ or when the syndicate adds a Canadian investor. The dependent variable for the "Domestic_Added" model is set to 1.0 when the incumbent syndicate adds a new Canadian investor to its syndicate at time $t$; and set to 0.0 when the incumbent syndicate does not add a new investor at time $t$ or it adds a foreign investor. 
For the multinomial logistic regression framework, model 5 is again employed but again the dependent variable is redefined as a three-level categorical variable coded as 0.0 when no new investor is added to syndicate $k$ at the $t^{\text {th }}$ financing round; 1.0 when a new venture capitalist is added and the new investor is Canadian; and 2.0 when a new venture capitalist is added and the new investor is foreign. The reference category is 1.0. As noted, Hypothesis $5 \mathrm{~b}$ predicts a significant negative relationship between incumbent venture capital fund size and the probability of foreign investor entry as well as a significant positive relationship between investee's growth and the probability of a foreign fund(s) entry. Capital constraints of the small incumbent venture capitalists call for further syndication with larger less financially constrained funds. However, the structure of the Canadian venture capital industry, with few large funds and many small funds, may oblige small funds to rely on foreign partners.

\section{1-5-2. Results: Pairwise and Multinomial Logistic Regression Models}

The results of the pairwise logistic regression are presented in Table V-13, and those of the multinomial logistic regression in Table V-14. As it was in the case of Hypothesis 5a, the two models generated similar results. The findings are, therefore, discussed mainly based on the pairwise logistic regression analysis unless specified otherwise. 
Table V-13: Pairwise Logistic Regression on Probability of Foreign (Canadian) Fund Entry (Later Rounds)

\begin{tabular}{|c|c|c|c|c|c|c|c|c|c|}
\hline & \multicolumn{4}{|c|}{ Foreign_Added } & \multicolumn{4}{|c|}{ Domestic_Added } \\
\hline & & $\mathrm{B}$ & S.E. & Wald & Sig. & B & S.E. & Wald & Sig. \\
\hline \multirow{4}{*}{$\begin{array}{l}\text { Indust } \\
\text { ry }\end{array}$} & & & & 1.035 & 0.793 & & & 5.526 & 0.137 \\
\hline & Life Sciences & 15.362 & 2948.449 & 0 & 0.996 & 0.149 & 0.327 & 0.209 & 0.648 \\
\hline & IT & 15.721 & 2948.449 & 0 & 0.996 & 0.419 & 0.303 & 1.905 & 0.168 \\
\hline & Other & 14.984 & 2948.449 & 0 & 0.996 & -0.193 & 0.404 & 0.227 & 0.634 \\
\hline \multicolumn{2}{|c|}{ In(\$AmountDisbursed) } & 2.501 & 0.336 & 55.55 & 0 & 0.468 & 0.066 & 50.573 & 0 \\
\hline \multirow{4}{*}{$\begin{array}{l}\text { Round } \\
\#\end{array}$} & & & & 7.723 & 0.052 & & & 17.845 & 0 \\
\hline & 3 rd & 0.438 & 0.596 & 0.541 & 0.462 & -0.573 & 0.219 & 6.82 & 0.009 \\
\hline & 4th & 1.854 & 0.731 & 6.44 & 0.011 & -1.033 & 0.271 & 14.546 & 0 \\
\hline & 5 th or more & 1.156 & 0.822 & 1.978 & 0.16 & -1.107 & 0.305 & 13.202 & 0 \\
\hline \multicolumn{2}{|c|}{ Time since lst Inv. } & 0.07 & 0.039 & 3.27 & 0.071 & 0.028 & 0.017 & 2.677 & 0.102 \\
\hline \multirow[t]{6}{*}{ Type } & & & & 9.241 & 0.1 & & & 5.869 & 0.319 \\
\hline & $\begin{array}{l}\text { Corporate } \\
\text { Affiliated }\end{array}$ & -0.643 & 1.226 & 0.275 & 0.6 & -0.017 & 0.355 & 0.002 & 0.962 \\
\hline & $\begin{array}{l}\text { Government } \\
\text { Affiliated }\end{array}$ & -0.33 & 0.682 & 0.234 & 0.629 & -0.22 & 0.263 & 0.705 & 0.401 \\
\hline & Government & 1.363 & 1.238 & 1.213 & 0.271 & -0.117 & 0.353 & 0.11 & 0.74 \\
\hline & Foreign & -0.317 & 0.737 & 0.185 & 0.667 & 0.454 & 0.377 & 1.454 & 0.228 \\
\hline & Other & 1.192 & 0.555 & 4.611 & 0.032 & -0.338 & 0.25 & 1.826 & 0.177 \\
\hline \multirow{5}{*}{$\begin{array}{l}\text { Locati } \\
\text { on }\end{array}$} & & & & 0.331 & 0.988 & & & 8.076 & 0.089 \\
\hline & $\mathrm{BC}$ & 0.175 & 0.684 & 0.065 & 0.798 & -0.379 & 0.316 & 1.44 & 0.23 \\
\hline & QC & -0.146 & 0.646 & 0.051 & 0.822 & 0.38 & 0.263 & 2.091 & 0.148 \\
\hline & $\begin{array}{l}\text { Prairies and } \\
\text { Atlantic }\end{array}$ & 18.384 & 4003.274 & 0 & 0.996 & -0.501 & 0.469 & 1.139 & 0.286 \\
\hline & Other & -0.206 & 0.581 & 0.125 & 0.723 & -0.048 & 0.243 & 0.039 & 0.844 \\
\hline \multicolumn{2}{|l|}{ Age } & -0.043 & 0.021 & 4.059 & 0.044 & 0.028 & 0.009 & 11.003 & 0.001 \\
\hline \multirow[t]{5}{*}{ Size } & & & & $\begin{array}{r}14.29 \\
1\end{array}$ & 0.006 & & & 14.006 & 0.007 \\
\hline & $\begin{array}{l}\text { Very Small } \\
(x<30)\end{array}$ & 3.886 & 1.067 & $\begin{array}{r}13.25 \\
4\end{array}$ & 0 & -0.212 & 0.396 & 0.286 & 0.592 \\
\hline & $\begin{array}{l}\text { Small } \\
(30<=x<75)\end{array}$ & 0.501 & 0.836 & 0.358 & 0.55 & 0.42 & 0.328 & 1.637 & 0.201 \\
\hline & $\begin{array}{l}\text { Large } \\
(165<=x<500)\end{array}$ & 0.32 & 0.686 & 0.218 & 0.641 & -0.079 & 0.265 & 0.088 & 0.767 \\
\hline & $\begin{array}{l}\text { Very Large } \\
(500<=x)\end{array}$ & 0.444 & 0.753 & 0.347 & 0.556 & -0.757 & 0.298 & 6.438 & 0.011 \\
\hline \multirow{2}{*}{\multicolumn{2}{|c|}{$\begin{array}{l}\text { Presence of Foreign } \\
\text { Fund } \\
\text { \# of Incumbents }\end{array}$}} & -0.545 & 0.548 & 0.991 & 0.32 & -0.499 & 0.274 & 3.304 & 0.069 \\
\hline & & & & 0.176 & 0.916 & & & 5.753 & 0.056 \\
\hline
\end{tabular}




\begin{tabular}{|c|c|c|c|c|c|c|c|c|c|}
\hline & $2,3,4$ & -0.351 & 0.865 & 0.165 & 0.685 & 0.515 & 0.26 & 3.923 & 0.048 \\
\hline & 5 or more & -0.394 & 1.003 & 0.154 & 0.694 & 0.124 & 0.362 & 0.117 & 0.732 \\
\hline \multirow{7}{*}{$\begin{array}{l}\text { Consta } \\
\text { nt }\end{array}$} & & -24.71 & 2948.449 & 0 & 0.993 & -1.021 & 0.472 & 4.668 & 0.031 \\
\hline & & \multicolumn{3}{|l|}{$\mathrm{N}$} & 789 & \multicolumn{3}{|l|}{$\mathrm{N}$} & 789 \\
\hline & & \multicolumn{3}{|c|}{ Foreign_Added } & 57 & \multicolumn{3}{|l|}{ Added } & 406 \\
\hline & & \multicolumn{3}{|c|}{$\begin{array}{l}\text { Not Added, or } \\
\text { Domestic Added }\end{array}$} & 732 & \multicolumn{3}{|c|}{ Not Added } & 383 \\
\hline & & \multicolumn{3}{|c|}{-2 Log likelihood } & 202.090 & \multicolumn{3}{|c|}{$\begin{array}{l}-2 \text { Log } \\
\text { likelihood }\end{array}$} & 937.930 \\
\hline & & \multicolumn{3}{|c|}{ p-value, model } & 0.000 & \multicolumn{3}{|c|}{ p-value, model } & 0.000 \\
\hline & & \multicolumn{3}{|c|}{$\begin{array}{l}\text { Cox \& Snell R } \\
\text { Square }\end{array}$} & 0.231 & \multicolumn{2}{|c|}{$\begin{array}{l}\text { Cox \& Snell R } \\
\text { Square }\end{array}$} & & 0.179 \\
\hline
\end{tabular}

* Dependent variable for "Foreign Added" specification is a binary variable equal to 1 when: (1) the incumbent venture capitalists add a new investor to their syndicate at time $t$; and (2) the entrant is foreign. It is 0.0 when: (1) the incumbent venture capitalists do not add a new investor at time $t$; or (2) they do but the entrant is Canadian. Dependent variable for "Canadian Added" specification is a binary variable equal to 1 when: (1) the incumbent venture capitalists add a new investor to their syndicate at time $t$; and (2) the entrant is Canadian. It is 0.0 when: (1) the incumbent venture capitalists do not add a new investor at time $t$; or (2) they do but the entrant is foreign.

* Independent variables are the same as those in the regressions in the previous subsection (1-4). 
Table V-14: Multinomial Logistic Regression on Probability of Foreign Fund Entry, Canadian Fund Entry, and No Entry (Later Round)

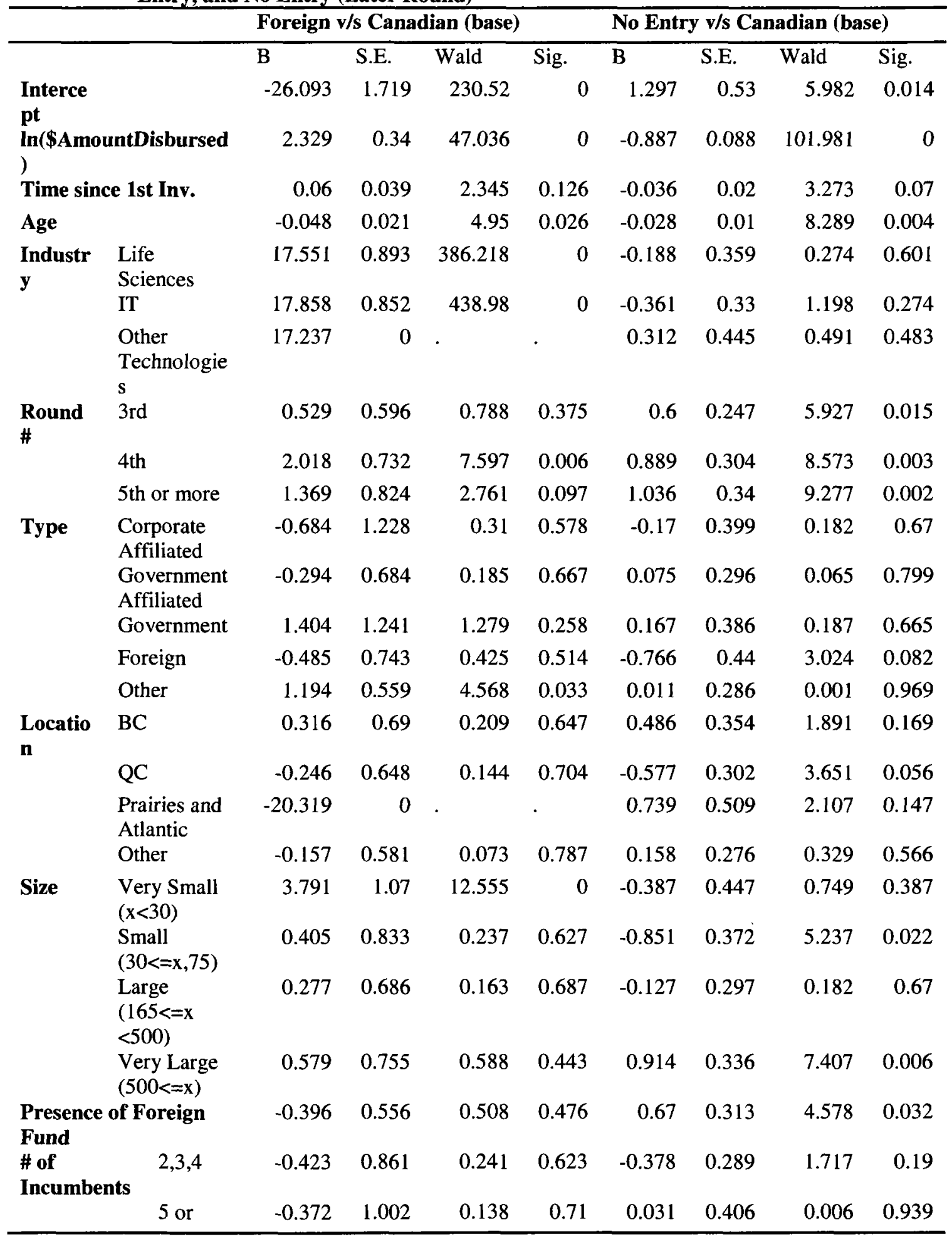




\begin{tabular}{lr}
\hline \multicolumn{1}{c}{ more } & 789 \\
$\mathbf{N}$ & 349 \\
Not Added & 383 \\
Canadian Added & 57 \\
Foreign Added & 961.025 \\
-2 Log Likelihood & 461.502 \\
Chi-Square & 50 \\
df & 0.000 \\
Sig. & 0.443 \\
Cox and Snell & 0.530 \\
Nagelkerke & 0.324 \\
McFadden & Dependent variable is a three-level categorical variable coded as 0.0 when no new investor is added to \\
* & syndicate $k$ at the $t^{\text {th }}$ financing round; 1.0 when a new venture capitalist is added and the new investor is \\
Canadian; and 2.0 when a new venture capitalist is added and the new investor is foreign. The reference \\
category is 1.0. \\
* Independent variables are the same as those in the regressions in the previous subsection (1-4).
\end{tabular}


The following key observations emerge from the estimation of the models. ${ }^{231}$

- In the "Canadian fund entry versus no fund entry" specification of the multinomial regression, the "foreign" category of the fund type variable was significant ( $p$-value $=0.082$ ). That is, when foreign funds form the majority of a syndicate, a Canadian fund was more likely to enter. This is probably in order to mitigate problems associated with distant investment and foreign funds' unfamiliarity with the Canadian market; ${ }^{232}$

- There was no significant difference in the likelihood of a foreign fund entry across deals in different regions. However, the unusually large standard error for the Prairie and Atlantic provinces is likely because no foreign fund entered into deals in those locations. ${ }^{233}$ Further investigation is necessary as to whether this is due to the lack of connections between venture capitalists in those provinces and foreign investors, or the lack of deals attractive to foreign funds. As for the odds

\footnotetext{
${ }^{231}$ Note that the three levels of the industry variable have identical and unusually large standard errors. This is because no foreign fund entered a later round deal in the "traditional" sector. It seems that foreign funds prefer investments in "high tech", while there was no difference in the odds ratio of a Canadian fund entrance across investments in different sectors. Also, the category "other" type-of-fund variable was significantly ( $p$-value $=0.032$ ) associated with foreign fund entry. Recall that this category includes cases of ties (e.g., a syndicate consists of two private independent, two LSVCCs). Accordingly, this finding does not readily lead to useful interpretation.

${ }^{232}$ Note that the "Foreign" category of the type variable was negative and significant, whereas the "presence of foreign fund" variable was positive and significant in the "Canadian fund entry versus no fund entry" specification. When foreign funds are the majority of the incumbent syndicate ( 62 cases), a local investor is more likely to enter to mitigate their distant investment problems. When the incumbent syndicate has one (or more) foreign fund (169 cases), the foreign fund's deeper pockets lessen the need of an additional source of capital.

${ }^{233}$ The large standard error for constant is due to the large standard errors for the industry variable and the "Prairie and Atlantic provinces" category of the location variable. When the sample excludes deals investing in traditional sectors and those in the Prairie and Atlantic provinces, the large standard error for constant disappears.
} 
ratio of a Canadian fund entry, the p-value of the overall "Location" variable is 0.089 , suggestive of a significant difference between deals in Quebec and those in British Columbia and the Prairie and Atlantic provinces. As already discussed, Quebec is the province in which a relatively large number of large funds are located, and British Columbia, the Prairie and Atlantic provinces are provinces where large funds are rare. The result probably indicates the relative ease of finding a large partner for Quebec investors and entrepreneurs; ${ }^{234}$

- The more experienced the incumbent syndicate, the less likely there was foreign fund entry and the more likely Canadian fund entry. This may be because a wellestablished network position of an experienced venture capitalist makes it easier to find a syndicate partner within Canada, diminishing the reliance on foreign funds' deeper pockets (Seppä and Jääskeläinen, 2002; Sorenson and Stuart, 2001; among others). Alternatively, experienced funds have no need to rely on foreign funds because they are usually large (see Appendix IV. also recall: the previous analysis finds that experienced funds were more likely to add a smaller fund than a larger fund); ${ }^{235}$

- As for the level of growth of the investee firm, the amount disbursed was significantly positively associated with the probabilities of both a foreign fund entry and a Canadian fund entry (p-values $=0.000)$. The greater the amount the

\footnotetext{
${ }^{234}$ The multinomial regression shows that Quebec deals were significantly more likely to add a Canadian fund (as opposed to not adding a new fund) than deals in other provinces.

${ }^{235}$ Then, however, a question arises: why would experienced venture capitalists add a small fund to their deal?
} 
investee required, the more likely an additional source of capital was necessary. The coefficient is larger for the probability of a foreign fund entry than that of a Canadian fund entry, and the Wald chi-square statistics indicates that the difference is significant $(35.250$, p-value $=0.000)$. This point was confirmed by the multinomial logistic regression, showing that a foreign fund is significantly more likely to enter as opposed to a Canadian fund ( $p$-value $=0.000$ ), and a Canadian fund is significantly more likely to enter as opposed to no fund entry (pvalue $=0.000$ ), as the amount required by the investee (proxied by the amount disbursed) increases. ${ }^{236}$ This is consistent with Hypothesis $5 b$, a foreign fund is more likely to participate as the investee firm grows and requires a larger amount of capital;

- The coefficients and their significance of the round number categories also support Hypothesis 5b. A foreign fund was significantly (p-value=0.011) more likely to enter at the fourth financing round, whereas a Canadian fund was most likely to enter at the second round than at the third, fourth, fifth or later (pvalue $=0.009,0.000,0.000$, respectively). The multinomial regression also shows that a foreign fund was significantly more likely to enter at the fourth or the fifth or later financing rounds ( $\mathrm{p}$-value $=0.006,0.097$, respectively). Thus, foreign funds tend to participate in deals at later rounds than do Canadian funds;

- The third measure of the level of investee's development, time since the first venture capital investment, had a positive and only marginally significant

\footnotetext{
${ }^{236}$ The reverse is also likely, however, that is: the entry of a foreign fund enables a larger capital infusion.
} 
association with the probabilities of both a foreign fund entry and a Canadian fund entry ( $p$-value $=0.071,0.102$, respectively). The difference of the two coefficients was insignificant. The multinomial regression confirmed this point;

- Finally, the size of the incumbent(s) exhibits an interesting result. ${ }^{237,238}$ For foreign fund entry, the fund size variable was statistically significant (p-value$=0.006$ ) and the pattern of coefficient estimates was consistent with the hypothesis (5b) that entry of a foreign fund was more likely for very-small-fund syndicates (p-value- $=0.000$ ). This may be an indication of the difficulty that very small Canadian funds face in accessing a larger fund as a syndicate partner within Canada, which may oblige them to rely on foreign sources of capital.

- The "syndicate size" variable was also statistically significant for the "Domestic_Added" model (p-value- $=0.007$ ); but the pattern of coefficient estimates was not so clear. However, the multinomial logistic regression revealed followings:

- As for syndicates with one or more very large or foreign fund:

- there was no significant difference in the probability of a foreign fund entry (as opposed to a Canadian fund entry) between syndicates with a

\footnotetext{
${ }^{237}$ A specification that includes the interaction term between the level of the investee's development (the amount disbursed) and the investor's(s') size was also attempted for both "Foreign Added" and "Domestic Added" models; however, it was insignificant.

${ }^{238}$ Table V-13 presents the estimation of the full model. In addition, a base model was estimated, one which omits the size-related variables, namely, the size of fund(s) and the presence of foreign fund. The collective addition of the block of variables that seek to measure size, improved the goodness of fit statistically significant degree ( $\mathrm{p}$-value, block $=0.035$ for the "Foreign Added" model and p-value, block $=0.000$ for the "Domestic Added" model).
} 
foreign fund and those without, as well as between syndicates with a very large fund and mid-sized syndicates;

- syndicates with a foreign/very large fund were significantly more likely not to add any investor (as opposed to adding a Canadian fund) than those without a foreign fund/mid-sized syndicates.

Those suggest that syndicates with a "very large" fund(s) or a foreign investor(s) have less need for an additional source of capital, thus are less likely to add a new investor of any type (foreign or Canadian). This is consistent with Hypothesis 2, and the foreign funds' tendency of not adding a fund of any type is in line with the previous finding (Hypothesis 5a) that foreign funds appear not to add a fund of any size. ${ }^{239}$

- "Small" sized syndicates were not significantly more (or less) likely to add a foreign fund, as opposed to a Canadian fund, but they were significantly more likely to add a Canadian fund, instead of not adding any investor. It appears that small sized syndicates are interested in adding a fund of any type, consistent with Hypothesis 2, and in line with a previously reported finding of Hypothesis 5a: small sized syndicates appear to add a fund of any size.

\footnotetext{
${ }^{239}$ In the pairwise regression, syndicates with a "very large" fund(s) and those with a foreign fund(s) were not significantly more (or less) likely to add a foreign fund ( $\mathrm{p}$-value $=0.556,0.320$, respectively). On the other hand, they were significantly less likely to add a Canadian investor ( $\mathrm{p}$-value $=0.011,0.069$, respectively).
} 


\section{1-5-3. Summary of Results: Hypothesis $5 b$}

The results of testing Hypothesis $5 b$ are summarized as follows:

- Quebec deals have a higher probability of a Canadian fund entry than do deals in British Columbia, the Prairies or the Atlantic provinces. This would seem to reflect the relative ease of finding a (large) syndicate partner in Quebec;

- The probability of a foreign fund entry was significantly higher:

o when the investee required a greater amount of capital infusion;

- at later (the fourth or fifth) financing rounds;

o when the incumbents were very small.

These results are consistent with Hypothesis $5 \mathrm{~b}$ and are also consistent with the view that when incumbent investors are small and are part of a community comprising relatively few large funds (that is, they are part of a Canadian venture capital community), foreign venture capital funds are more likely to participate at later stages of financing as the investee firms grow and require larger amounts of capital. 


\section{1-6. Summary of Results: Syndication Analyses}

The results of the analyses of the Canadian venture capital syndication practices are summarized in Table V-15.

\section{Table V-15: Summary of Results of Syndication Analyses}

\begin{tabular}{|c|c|c|c|}
\hline Hypothesis & Key results & & \\
\hline $\begin{array}{l}\text { Hypothesis 1: Smaller venture } \\
\text { capital funds are more likely to } \\
\text { be capital constrained (that is, } \\
\text { to have smaller amounts of } \\
\text { capital available for each of its } \\
\text { portfolio companies). } \\
\text { Hypothesis 2: Small venture } \\
\text { capital funds syndicate more } \\
\text { often. }\end{array}$ & $\begin{array}{l}\text { Within Canada Analyses } \\
\text { - Measures of capital availability were significantly correlated with size } \\
\text { Within Canada Analyses } \\
\text { - A high level of syndication activity (measured by syndication ratio) was } \\
\text { observed in Canada } \\
\text { Canada-US Comparison } \\
\text { - Large funds in Canada maintained a disproportionally large number of investee } \\
\text { firms in their portfolios, relative to those in the US. } \\
\text { - The number of investors per financing round was significantly larger in Canada } \\
\text { than in the US. The impact of a dollar increase in investment size on the number } \\
\text { of investors is greater for Canadian deals. }\end{array}$ & Consistent & \\
\hline$\ldots$ & $\begin{array}{l}\text { Within Canada Analyses } \\
\text { - Analysis of syndication ratio: There was no difference in propensity to } \\
\text { syndicate between large and small funds (within Canada). }\end{array}$ & Reject $^{240}$ & \\
\hline
\end{tabular}

\footnotetext{
${ }^{240}$ This is probably because in Canada, a large number of small funds need syndication partners in order to provide a sufficient amount of capital to their investees, and thus a small number of large funds are sought after by those small funds - resulting in a high level of syndication activities even for large funds. This is consistent with the Bottleneck hypothesis: syndication activity is high in a community comprised of a large number of small funds and a small number of large funds.
} 
- Analysis of first round investments: syndicated deals were more likely to have Reject $^{241}$ one (or more) large funds and sole deals were more likely to be made by small funds.

- Analysis of later financing rounds:

- When the incumbent syndicate had one (or more) very large fund, a new Consistent investor was significantly less likely to enter.

- When the incumbent syndicate was comprised of small or very small funds, Consistent the probability of a new investor entry was significantly high.

- Incumbent syndicates with a (or more) foreign fund were significantly less Consistent likely to add a new investor.

\footnotetext{
${ }^{241}$ However, due to the lack of information on lead investor (see V-2-2-3 for detail), the logistic regression here analyzes the impact of the size of all the investors (rather than the size of the lead) on the probability of the deal to be syndicated. It is, therefore, possible to interpret this result as: large funds and syndicated investments are correlated because they are more likely to enter a deal initiated by another fund; small funds made a sole investment when they had no need of additional sources of capital (or, they did but were unable to find an additional source of capital) for the first round investment of the deal they discovered.
} 


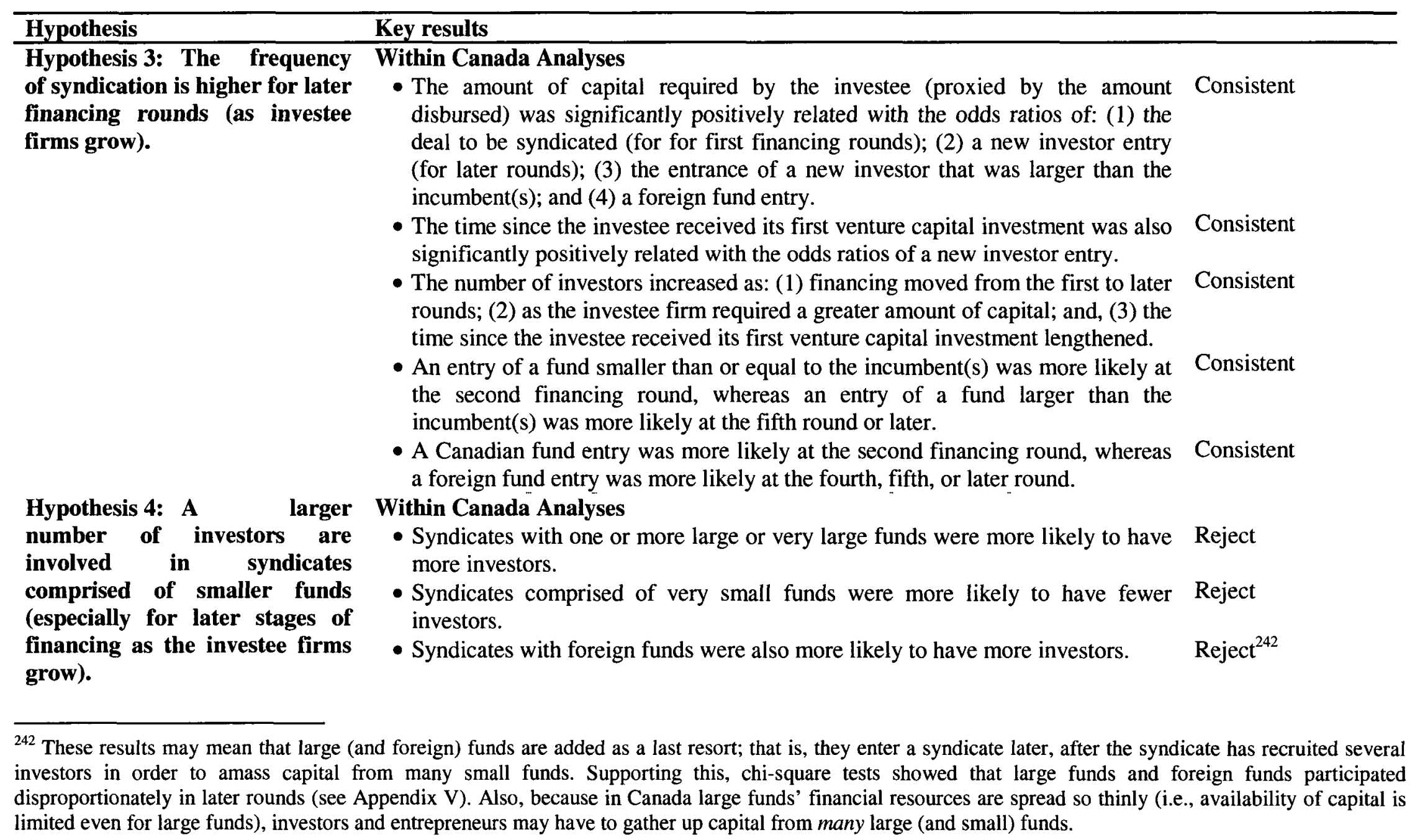




\begin{tabular}{l}
\hline Hypothesis \\
\hline \\
Hypothesis 5a: The smaller the \\
incumbent investor(s), the more \\
likely that a new investor, \\
larger than the incumbent(s), is \\
added to the syndicate, \\
especially at later stages of \\
financing (as the investee firm \\
grows).
\end{tabular}

\section{Hypothesis 5b: When \\ incumbent investors are small}

\section{Key results}

\section{Canada-US Comparison}

- The number of investors per financing round was significantly larger in Canada

\section{Consistent} than the US. The number of investors and the amount invested were significantly positively related for both Canadian and American deals, but the impact of a dollar increase in investment size was significantly greater for Canadian deals.

\section{Within Canada Analyses}

- "Very small" syndicates were significantly less likely to add an equal-sized Consistent fund and more likely to add a larger fund.

- "Large" syndicates were significantly less likely to add a larger fund and more Consistent likely to add a smaller or an equal-sized fund.

- "Very large" syndicates were significantly more likely to add a smaller or an Consistent ${ }^{243}$ equal-sized fund.

- Incumbent syndicates with one (or more) foreign investor(s) appear to be Consistent interested in neither a large nor a small fund entry.

\section{Within Canada Analyses \\ - The probability of a foreign fund entry was significantly higher when the}

\section{Consistent}

\footnotetext{
${ }^{243}$ However, the results should be viewed with a caveat. These results may simply reflect the absolute number of potential syndicate partners for funds in each size category. That is: small funds have a large number of potential syndicate partners that are larger than they are; and large funds have a large number of potential syndicate partners that are smaller than they are.
} 


\begin{tabular}{ll}
\hline Hypothesis & Key results \\
\hline $\begin{array}{l}\text { and are part of a community } \\
\text { comprising relatively few large } \\
\text { funds, foreign venture capital } \\
\text { funds are more likely to } \\
\text { participate at later stages of } \\
\text { financing (as the investee firms } \\
\text { grow). }\end{array}$ \\
$\begin{array}{ll}\text { Other important results } & \begin{array}{l}\text { Funds located in the Prairies and the Atlantic provinces had a lower propensity to syndicate. } \\
\text { - Quebec deals had a significantly higher probability of a new investor entry - a new large (Canadian) } \\
\text { fund entry in particular - than those made in other provinces; }\end{array} \\
& \begin{array}{l}\text { The number of syndicate members was greater for deals in Ontario and Quebec than for those in } \\
\text { British Columbia, the Prairies and the Atlantic provinces. }\end{array} \\
\text { These observations probably reflect the differences in the structure of the venture capital sector across } \\
\text { different provinces. Quebec is the province in which most of the large funds are located (eleven in total, } \\
\text { and six of those are Canada's largest), and Ontario has the second most, namely nine. In contrast, there are } \\
\text { only five large funds in British Columbia, two in Alberta, one in Manitoba, one in Saskatchewan, and } \\
\text { none in any of the Atlantic provinces (see IV-2-3). }\end{array}$ \\
\hline
\end{tabular}

\footnotetext{
${ }^{244}$ This may be an indication that in Canada, investors and entrepreneurs must gather up capital from many large (and small) funds (as large funds' financial resources are spread so thinly). This is relatively more feasible in Quebec and Ontario (since the majority of large funds are located there) than in British Columbia, in the Prairies or in the Atlantic provinces.
} 


\section{2- Results on Exit Practices}

\section{2-1. Hypothesis 6}

Hypothesis 6: Entrepreneurial firms backed by small funds receive smaller amounts of venture capital than those backed by large funds by the time of their exits.

To test Hypothesis 6, the following model of venture capital financing was estimated using ordinary least squares.

$$
\operatorname{Ln}\left(T O T A L \$_{j}\right)=\alpha_{0}+\alpha_{l} * S I Z E_{i / k}+\tilde{\alpha}_{2} * \tilde{C} \text { ontrol }+\varepsilon_{i / k, j},
$$

where: $T O T A L \$_{j}=\quad$ Total amount of venture capital received by investee firm $j$ by the time of its exit.

$S I Z E_{i / k}=\quad \begin{aligned} & \text { A size measure of venture capital fund } i \text { or syndicate } k \text { at the time } \\ & \text { of exit. }\end{aligned}$
$\begin{aligned} & \text { A vector of variables controlling for the characteristics of the } \\ & \text { deal, exit (IPO or M\&A, International or domestic), as well as } \\ & \text { venture capital fund } i \text { (or syndicate } k \text { ) and entrepreneurial firm } j \\ & \text { at the time of exit. }\end{aligned}$
$\begin{aligned} & \text { Error term. }\end{aligned}$

The dependent variable in the model is the natural logarithm of the total amount of venture capital received by an investee firm by the time of its exit. The independent variables of interest are measures of the capital availability of the investor(s). As was the case for the syndication analyses, three such measures were employed:

- Size: the amount of capital under management of the fund (if only one investor) or the amount of capital under management of the largest fund in the syndicate (if 
there is more than one investor) at the time of the financing round prior to the exit. $^{245}$

- The presence of a foreign investor: a dummy variable coded 1.0 when the fund is foreign (if one investor) or when at least one foreign fund participates in the syndicate (if more than one investor), 0.0 for deals with no foreign fund involvement by the time of the financing round prior to the exit;

- The number of venture capital funds involved in the syndicate at the time of the financing round prior to the exit.

Control variables include attributes of the deal, the venture capital funds, and the entrepreneurial firm (see Appendix II for the list of control variables used for the analyses of exit).

A problem associated with this analysis is the small sample size. Of 91 exited entrepreneurial firms, the variable "total amount of venture capital infused by the time of its exit" was available for only 50 firms (39 M\&As and 11 IPOs). The presence of missing values associated with independent and control variables further reduced the sample size to 43 cases (35 M\&As and 8 IPOs). Consequently, if all the originally planned independent and control variables had been included, there would have been too

\footnotetext{
${ }^{245}$ As in the case of the syndication testing, the size of the venture capital investors is measured based on the fund size (capital under management of the fund) rather than the firm size (i.e., the sum of funds managed by the venture capital firm).
} 
many explanatory variables for the number of observations. To accommodate for this, the following two procedures were employed:

1. The number of levels of categorical variables was reduced. For example, the number of levels of the size variable, previously five (very small, small, middle, large, very large) was reduced to two (small and large) in this analysis;

2. A stepwise procedure was used for the inclusion of the control variables. In this procedure, the first predictor to enter the model was the variable with the largest simple correlation with the dependent variable. If this predictor was significant, then the predictor with the largest semi partial correlation with the dependent variable was then considered, and so on. At each stage of the procedure, a test was made of the least useful predictor, that is, the importance of each predictor was reassessed at each stage (Stevens, 1996, p.81). ${ }^{246}$

${ }^{246}$ The explanatory variables (the three measures of the size of the investors) were forced to enter the model, while control variables entered through the stepwise procedure. As robustness checks, the following variations were also employed. One variation involved the re-estimation of the model with the three explanatory (size) variables being forced to enter and control variables entered via forward and backward procedures. In a second variation, all predictors (both independent and control variables) entered via the stepwise, forward and backward procedures. The number of syndication members, Quebec deal, and the second round variables were significant in all attempts while size was insignificant (and instead, the presence of foreign fund variable was significant) in some specifications. The three measures of investor size (size of the largest fund in the syndicate, presence of foreign fund and number of syndication members) were correlated. Foreign funds were more likely to be in a syndicate with a large number of investors and/or a syndicate with a (or more) large fund (see Appendix V). Thus, the multicolinearity problem, exacerbated by the small sample size, makes it difficult to extract the pure effect of each of these three measures. Therefore, again, further research, with a larger sample, is necessary. 
Table V-16: OLS Regression on Amount Invested by the Time of Exit

\begin{tabular}{lrrrr}
\hline & B & \multicolumn{1}{c}{ S. E. } & t-value & \multicolumn{1}{l}{ Sig. } \\
\hline Constant & -0.022 & 0.261 & -0.083 & 0.935 \\
\# of Syndicate Members & 0.409 & 0.072 & 5.707 & 0.000 \\
Presence of Foreign & 0.326 & 0.350 & 0.929 & 0.359 \\
Fund & & & & \\
Size & 0.546 & 0.270 & 2.019 & 0.051 \\
Location_QC & -1.156 & 0.272 & -4.253 & 0.000 \\
Round\#_2nd & 0.573 & 0.249 & 2.307 & 0.027 \\
R & 0.847 & & & \\
R Square & 0.717 & & & \\
Adjusted R Square & 0.679 & & & \\
\hline
\end{tabular}

* Dependent variable is the natural logarithm of the total amount of venture capital invested in the entrepreneurial firm.

* Explanatory variables are: (1) size (a dummy variable equals 1.0 if the amount of capital under management of the fund (if only one investor) or the largest fund in the syndicate (if more than one investor) is greater than or equal to $\$ 165$ million $\mathrm{CDN} ; 0.0$ otherwise); (2) the number of syndicate members; and, (3) the presence of foreign fund (a dummy variable equals 1.0 if there is a (or more) foreign fund in the syndicate; 0.0 otherwise). These variables are forced to enter the equation.

* Control variables include: (1) industry (a dummy variable coded 1.0 if the investee is in the high-tech sector (Life Sciences, IT, Other Technologies), 0.0 if Traditional); (2) number of days since the investee received its first venture capital investment (in 100 days); (3) round number of the financing round prior to the exit (first, second, third or more; two dummies with base case of first); (4) type of fund (if one investor) or the type of the funds that form the majority of funds in the syndicate (if more than one investor). A dummy variable coded 1.0 if not private independent, 0.0 if private independent; (5) location of the deal (four dummies: Ontario, British Columbia, Quebec, the Prairies and the Atlantic provinces, other, with base case of Ontario, see Appendix II for the definition); (6) level of experience of the fund (if one investor) or level of experience of the most experienced fund in the syndicate (if more than one investor), measured by the age of the management company of the fund; (7) exit location (a dummy variable equals 1.0 if the investee was acquired by a non-Canadian corporation or listed on a foreign exchange; 0.0 otherwise); (8) type of exit (a dummy variable equals 1.0 if the investee was exited via an IPO; 0.0 via $M \& A)$. Control variables enter the equation through the stepwise procedure.

* The analyses employ, as alternate specifications, each of the following four measures of experience to ensure robustness of findings: the age of the management company of the fund, the number of funds the management company of the fund had raised, the number of entrepreneurial firms the management company of the fund had invested, and the number of exits the management company of the funds had experienced, at/by the time of the deal was made. For syndicated deals, experience is measured by the level of experience of the most experienced fund in the syndicate. For each of the four measures of experience, a natural $\log$ and categorical transformations are also attempted (except for the number of exit variable, which produces a large number of missing values when transformed to the natural logarithm, i.e., there are a number of funds that have not attained a successful exit). For the sake of brevity, however, the specification using age of fund (as a natural number value) as an experience variable is reported. Results of specifications with other experience measures (and with/without the natural $\log$ /categorical transformations) do not differ from the above, and are available upon request. 
The results are presented in Table V-16. Given the small sample size, they should be viewed with caution and may not be conclusive. ${ }^{247}$

- Among the control variables, the Quebec dummy location variable entered the equation and was negative and significant at $p$-value $=0.000$. The entrepreneurial firms in Quebec received a significantly smaller amount of venture capital by the time of their exits. This appears, at a first glance, surprising given that the previous section (section one) reported a significantly higher level of syndication activity in Quebec attributable to the relatively large number of large funds within the province. The presence of large funds and the high level of syndication activity naturally led to an expectation of a significantly larger amount of venture capital infusion into Quebec entrepreneurial firms; however, the empirical observation exhibited a pattern contrary to this expectation.

This seemingly contradictory result may reflect the characteristics of very large funds in Quebec. Nine out of eleven very large funds in Quebec are non-private independent and hold a large number of portfolio companies (see Table IV-4), implying relatively high syndication activity in Quebec yet small capital infusions in each company. ${ }^{248}$ In particular, three of the nine non-private independent funds, Fonds de solidarité (FTQ) National, Fonds de solidarité (FTQ) Regional, and

\footnotetext{
${ }^{247}$ Ideally, the amount of capital raised should be adjusted for performance by expressing the amount raised as a fraction of a performance measure (such as annual sales revenue) in order to control for scale. However, no pre-exit performance measures were available for M\&A and there were only 11 IPOs. Postexit measures for M\&A were also unavailable, and the measures for IPOs arguably reflected the effects of the capital raised in the issue.

${ }^{248}$ Recall that Canadian large non-private independent funds hold significantly larger number of portfolio companies than the size-comparable American funds (see V-1-1-2).
} 
FondActrion are non-rent-a-union LSVCCs, pursuing objectives other than profit maximization (such as job retention and creations, investing in small-and medium companies in traditional sectors (Hebb and Mackenzie, 2001; see II-1-2-5)). Those funds are probably less likely to pursue aggressively a successful exit by making a large capital infusion in a few promising entrepreneurial firms.

- Entrepreneurial firms exited after a second round of capital infusion received a significantly greater amount of venture capital than those exited after their first, third, or later round of capital infusion. The rationale behind this observation is also unclear. Recall that the syndication analyses of the previous section observed that a new investor was most likely to enter a syndicate at the second financing round. The result obtained here may reflect this higher probability of a new investor entry at the second round. Nevertheless, this rationale does not explain why companies exited after the second round receive more capital than those exited after the third or later round.

- Two out of the three measures of the investors' capital availability were significant. The number of syndicate members was strongly related to the total amount of capital infusion, with p-value of 0.000 . A larger number of investors in a syndicate means that the capital is gathered from more sources, and thus a greater amount of capital infusion is possible. The size of the fund (or the largest fund in the syndicate) was also significantly positively correlated, with p-value = 0.051. Being backed by a large investor with deep pockets enables an 
entrepreneurial firm to receive a greater capital infusion. These are consistent with Hypothesis 6: entrepreneurial firms backed by small funds receive smaller amounts of venture capital than those backed by large funds by the time of their exits.

The above analysis suggests that Canadian entrepreneurial firms (and early venture capital investor funds) amass capital in both of the following two ways: by inviting one or more large fund(s) to their syndicate; and, by inviting many funds to take part in their syndicate. They make full use of syndication (manifested in the form of high syndication measures) in order to take their investee firms to the optimal exit.

\section{2-2. Hypothesis $7 \& 8$}

Hypothesis 7: Successful exits are less likely when early investors are small funds.

Hypothesis 8: Relative to IPO exits, acquisition exits are more likely when early investors are small.

Following Gompers and Lerner (1999b), Gompers, Kovner, Lerner, and Scharfstein (2005), Brander, Egan, and Hellmann (2008), and many others, an IPO or an acquisition is considered a successful exit. The effect of size on the likelihood of a successful exit was estimated using a proportional hazard model of time to exit.

$$
\frac{h_{g}(t)}{h_{j}(t)}=\exp \left(\beta_{1}\left(S I Z E_{g}-S I Z E_{j}\right)+\tilde{\beta}_{2}\left(\tilde{C}_{\text {ontrol }}-\tilde{C} \text { Control }_{j}\right)\right.
$$


where: $\frac{h_{g}(t)}{h_{j}(t)}=$

$$
S I Z E_{f}=
$$

$\widetilde{C}$ ontrol $_{t}=$ the ratio of the hazard function (the hazard ratio) to a successful exit for two subjects $g$ and $j .^{249}$

A size measure of venture capital fund $i$ or syndicate $k$ backing entrepreneurial firm, $i \in g, j, k \in g, j$.

A vector of variables controlling for the characteristics of the deal, exit, entrepreneurial firm, as well as venture capital fund $i$ (or syndicate $k$ ), $i \in g, j, k \in g, j$.

The proportional hazards model was employed as it allows for censoring (unlike static models, such as probit or logistic). The sample includes not only entrepreneurial firms exited via a successful exit but also those exited through a buyback or a write-off (the time to exit is unknown for these observations) as well as an unknown number of entrepreneurial firms that have a finite positive probability of a successful exit but have not yet exited (the latter two are referred to as "censored observations"). ${ }^{250}$ Hazard models are sufficiently flexible to handle these complexities and incorporate information from both censored and uncensored observations to provide consistent parameter estimates. $^{251,252}$

The effect of size was examined on the hazards of each of:

${ }^{249} h_{i}(t)=\lambda_{0}(t) \exp \left(\beta_{1} S I Z E_{i}+\widetilde{\beta}_{2}\right.$ Contro $\left.\tilde{l}_{i}\right)$, where $h_{i}(t)=$ the hazard function for $i$.

$\lambda_{0}(t)=$ the baseline hazard function.

${ }^{250}$ The Thomson Financial VCReporter data does not distinguish between companies exited via a buyback or a write-off and those that are with a positive probability of a successful exit but have not exited.

${ }_{251}$ Excluding censored observations results in non-randomness in the sample and thus biased estimations.

252 Another advantage of the proportional hazards model is that it allows for time-dependent covariates, factors that may influence the probability of exit that vary over time. However, this analysis has no timevarying covariates. 
1. A successful exit (for IPOs and M\&As, treating all other observations as censored: "Exit model");

2. An M\&A exit (treating all other observations (including IPO exits) as censored: "M\&A model"); and,

3. An IPO (treating all other observations (including M\&A exits) as censored: "IPO model").

Three proportional hazard models were, therefore, estimated. The explanatory variables include the three measures of size as used in the analyses of syndication, namely:

1. Size: the amount of capital under management of the fund (if there is only one investor) or the amount of capital under management of the largest fund in the syndicate (if there is more than one investor), at the time of the financing round prior to the exit (or the termination point of December $31^{\text {st }}, 2009$ ). ${ }^{253}$ Deals are then ranked and classified into five quintiles based on the investor's/syndicate's size;

2. The number of venture capital funds involved in the syndicate: a categorical variable with three levels: only one investor, two to four investors, and five or more investors, at the time of the financing round prior to the exit (or the termination point);

\footnotetext{
${ }^{253}$ Two additional specifications were also attempted. One included the three size measures at the time of the first financing round (instead of those at the time of the last financing round). The other included the three size measures at the time of the first financing round and the time of the last round. The results did not change materially from those presented here, and the size measures at the time of the first financing round were insignificant.
} 
3. The presence of a foreign investor: a dummy variable coded 1.0 when the investor fund is foreign (if one investor) or when the investor syndicate has at least one foreign fund (if more than one investor), 0.0 for deals with no foreign fund involvement, by the time of the financing round prior to the exit (or the termination point). ${ }^{254}$

Control variables include the industry sector of the investee, the level of the investee's development (the amount of venture capital disbursed at, and the round number of, the latest financing round), the location of the deal, the type of the fund/syndicate, and the level of the experience of the fund/syndicate. For detailed descriptions of these control variables, see Appendix II.

There were 42 M\&A exits and 12 IPO exits among 426 entrepreneurial firms that received venture capital investments during the period from January $1^{\text {st }}, 2001$ to December $31^{\text {st }}, 2006 .^{255}$ Due to the small number of IPO observations, the results of IPO exits are not conclusive. Hypothesis 7 predicts a positive association between the fund size and the hazard to a successful exit, and Table V-17 presents the results.

\footnotetext{
${ }^{254}$ Duruflé (2006; see also II-3-4) reported that when foreign investors are involved in a deal, a Canadian venture capital-backed company receives a substantially larger amount of venture capital and the value of a Canadian venture capital-backed company at the time of the exit is substantially higher. Moreover, the presence of foreign investors is likely correlated with the exit location, as it is reported to increase the chance of foreign exits through their networks and knowledge on the foreign market.

${ }^{255}$ Entrepreneurial firms that received venture capital investments in or after 2007 were excluded as they were considered too premature to attain a successful exit by the time of the analysis (in fact, there was only one, among those firm in the usable sample, had exited by December $31^{\text {st }}, 2009$ ).
} 
Table V-17: Proportional Hazard Model on Time to Successful Exit, M\&A, IPO

\begin{tabular}{|c|c|c|c|c|c|c|c|c|c|c|c|c|}
\hline & Exit & & & & $\mathbf{M \& A}$ & & & & IPO & & & \\
\hline & B & S.E. & Wald & Sig. & B & S.E. & Wald & Sig. & B & S.E. & Wald & Sig. \\
\hline Industry & & & 3.176 & 0.365 & & & 6.183 & 0.103 & & & 5.356 & 0.148 \\
\hline Life Sciences & 0.535 & 0.556 & 0.928 & 0.335 & 0.072 & 0.693 & 0.011 & 0.918 & 1.103 & 1.214 & 0.825 & 0.364 \\
\hline IT & 0.814 & 0.513 & 2.518 & 0.113 & 1.054 & 0.572 & 3.391 & 0.066 & -0.739 & 1.285 & 0.330 & 0.565 \\
\hline $\begin{array}{l}\text { Other } \\
\text { Technologies }\end{array}$ & 0.125 & 0.861 & 0.021 & 0.885 & -12.576 & 501.744 & 0.001 & 0.980 & 1.039 & 1.388 & 0.561 & 0.454 \\
\hline $\begin{array}{l}\ln (\$ A \text { mountDisburs } \\
\text { ed) }\end{array}$ & 0.200 & 0.136 & 2.173 & 0.140 & 0.185 & 0.161 & 1.317 & 0.251 & 0.227 & 0.298 & 0.580 & 0.446 \\
\hline Round\# & & & 3.810 & 0.283 & & & 3.303 & 0.347 & & & 1.241 & 0.743 \\
\hline $2 \mathrm{nd}$ & 0.389 & 0.385 & 1.021 & 0.312 & 0.110 & 0.429 & 0.065 & 0.798 & 1.077 & 1.039 & 1.074 & 0.300 \\
\hline $3 \mathrm{rd}$ & 0.195 & 0.471 & 0.171 & 0.679 & -0.115 & 0.539 & 0.045 & 0.832 & 1.008 & 1.239 & 0.662 & 0.416 \\
\hline 4th or more & -0.594 & 0.607 & 0.960 & 0.327 & -1.215 & 0.793 & 2.347 & 0.126 & 1.234 & 1.301 & 0.900 & 0.343 \\
\hline Type & & & 3.155 & 0.676 & & & 1.360 & 0.929 & & & 3.049 & 0.693 \\
\hline $\begin{array}{l}\text { Corporate } \\
\text { Affiliated }\end{array}$ & 0.170 & 0.599 & 0.080 & 0.777 & 0.119 & 0.613 & 0.037 & 0.847 & -12.366 & 443.567 & 0.001 & 0.978 \\
\hline $\begin{array}{l}\text { Government } \\
\text { Affiliated }\end{array}$ & -0.087 & 0.441 & 0.039 & 0.843 & -0.290 & 0.488 & 0.354 & 0.552 & 0.302 & 1.165 & 0.067 & 0.795 \\
\hline Government & -0.056 & 0.591 & 0.009 & 0.925 & -0.356 & 0.668 & 0.283 & 0.594 & 0.910 & 1.433 & 0.403 & 0.525 \\
\hline Foreign & -1.840 & 1.084 & 2.882 & 0.090 & -14.735 & 686.250 & 0.000 & 0.983 & -0.030 & 1.495 & 0.000 & 0.984 \\
\hline Other & 0.006 & 0.377 & 0.000 & 0.988 & -0.428 & 0.444 & 0.930 & 0.335 & 1.365 & 0.928 & 2.166 & 0.141 \\
\hline Location & & & 3.115 & 0.539 & & & 3.242 & 0.518 & & & 1.457 & 0.834 \\
\hline $\mathrm{BC}$ & -0.151 & 0.461 & 0.108 & 0.743 & -0.526 & 0.570 & 0.854 & 0.356 & 0.781 & 0.934 & 0.699 & 0.403 \\
\hline QC & -0.734 & 0.451 & 2.641 & 0.104 & -0.905 & 0.521 & 3.017 & 0.082 & -0.465 & 1.049 & 0.197 & 0.657 \\
\hline $\begin{array}{l}\text { Prairies and } \\
\text { Atlantic }\end{array}$ & 0.052 & 0.837 & 0.004 & 0.950 & -0.401 & 1.143 & 0.123 & 0.726 & 0.048 & 1.461 & 0.001 & 0.974 \\
\hline
\end{tabular}




\begin{tabular}{|c|c|c|c|c|c|c|c|c|c|c|c|c|}
\hline Other & -0.278 & 0.442 & 0.395 & 0.530 & -0.366 & 0.509 & 0.517 & 0.472 & -0.050 & 1.084 & 0.002 & 0.963 \\
\hline Age & -0.034 & 0.017 & 3.900 & 0.048 & -0.052 & 0.021 & 6.373 & 0.012 & 0.046 & 0.038 & 1.503 & 0.220 \\
\hline Size & & & 3.650 & 0.455 & & & 9.713 & 0.046 & & & 5.124 & 0.275 \\
\hline $\begin{array}{l}\text { Very Small } \\
(x<30)\end{array}$ & 0.246 & 0.651 & 0.143 & 0.705 & 0.091 & 0.799 & 0.013 & 0.909 & 0.751 & 1.289 & 0.340 & 0.560 \\
\hline Small $(30<=x, 75)$ & -0.110 & 0.656 & 0.028 & 0.867 & -0.235 & 0.865 & 0.074 & 0.786 & 0.298 & 1.190 & 0.063 & 0.802 \\
\hline $\begin{array}{l}\text { Large } \\
(165<=x<500)\end{array}$ & 0.603 & 0.496 & 1.479 & 0.224 & 1.205 & 0.575 & 4.398 & 0.036 & -2.308 & 1.343 & 2.953 & 0.086 \\
\hline $\begin{array}{l}\text { Very Large } \\
(500<=x)\end{array}$ & 1.059 & 0.618 & 2.942 & 0.086 & 2.076 & 0.743 & 7.817 & 0.005 & -2.217 & 1.288 & 2.960 & 0.085 \\
\hline $\begin{array}{l}\text { Presence of Foreign } \\
\text { Fund }\end{array}$ & 0.061 & 0.429 & 0.020 & 0.887 & 0.120 & 0.524 & 0.052 & 0.820 & -0.595 & 0.972 & 0.375 & 0.541 \\
\hline $\begin{array}{l}\text { \#Syndicate } \\
\text { Members }\end{array}$ & & & 4.731 & 0.094 & & & 4.636 & 0.098 & & & 0.905 & 0.636 \\
\hline $2,3,4$ & 1.446 & 0.682 & 4.503 & 0.034 & 1.738 & 0.809 & 4.618 & 0.032 & 0.068 & 1.414 & 0.002 & 0.961 \\
\hline 5 or more & 1.690 & 0.827 & 4.180 & 0.041 & 1.835 & 0.973 & 3.556 & 0.059 & 1.031 & 1.808 & 0.325 & 0.569 \\
\hline $\mathbf{N}$ & & & & 426 & & & & 426 & & & & $425^{256}$ \\
\hline Successful Exit & & & & 54 & & & & 42 & & & & 12 \\
\hline Censored & & & & 372 & & & & 384 & & & & 413 \\
\hline -2 Log Likelihood & & & & 571.993 & & & & 419.617 & & & & 110.596 \\
\hline Chi-square & & & & 59.533 & & & & 70.307 & & & & 31.514 \\
\hline df & & & & 24 & & & & 24 & & & & 24 \\
\hline Sig. & & & & 0.000 & & & & 0.000 & & & & 0.139 \\
\hline
\end{tabular}

* Dependent variable is the ratio of the hazard function (the hazard ratio) to a successful exit, an M\&A, an IPO.

* Industry is the sector in which the investee company operates (base category $=$ Traditional).

\footnotetext{
${ }^{256}$ There is one observation censored before the earliest event in a stratum and thus excluded from the analysis.
} 
* $\ln (\$$ AmountDisbursed) is the natural logarithm of the dollar amount of venture capital disbursed to the investee at the financing round prior to the exit or the termination point of December $31^{\text {st }}, 2009$ (in million CDN).

* Round\# is the round number of the last financing round prior to the exit or the termination point (base category $=1^{\text {st }}$ round).

* Time since 1 st Inv. is the number of days since the $1^{\text {st }}$ venture capital investment to the financing round prior to the exit or the termination point (in 100 days).

* Type is the type of fund (if there is one investor) or the type of the funds that form the majority of funds in the syndicate (if there are more than one investors, base category $=$ private independent) as of the financing round prior to the exit or the termination point.

* Location is the province in which the fund and the investee are located (if there is one investor), or the location in which the funds that form the majority of funds in the syndicate and the investee are located (if there are more than one investors, base category = Ontario) as of the financing round prior to the exit or the termination point.

* Age is the age of the management company of the fund (if there is one investor) or the age of the oldest management company of the funds participating in the deal (if there are more than one investors) as of the financing round prior to the exit or the termination point.

* Size is the amount of capital under management of the fund (if there is one investor) or the amount of capital under management of the largest fund in the syndicate (if there are more than one investors, base category $=$ Middle $(75<=x<165$ in $\$$ million $C D N)$ ) as of the financing round prior to the exit or the termination point.

* Presence of foreign investor takes the value 1 if there is at least one foreign fund participating in the deal, 0 otherwise, as of the financing round prior to the exit or the termination point.

* \# Syndicate Members is the number of venture capital funds in the deal, as of the financing round prior to the exit or the termination point.

* The analyses employ, as alternate specifications, each of the following four measures of experience to ensure robustness of findings: the age of the management company of the fund, the number of funds the management company of the fund had raised, the number of entrepreneurial firms the management company of the fund had invested, and the number of exits the management company of the funds had experienced, at/by the time the deal was made. For syndicated deals, experience is measured by the level of experience of the most experienced fund in the syndicate. For each of the four measures of experience, a natural $\log$ and categorical transformations are also attempted (except for the number of exit variable, which produces a large number of missing values when transformed to the natural logarithm, i.e., there are a number of funds that have not attained a successful exit). For the sake of brevity, however, the specification using age of fund (as a natural number value) as an experience variable is reported. The results of specifications with other experience measures (and with/without the natural log/categorical transformations) do not differ from the above, and are available upon request. 
As expected, while the Exit and M\&A models were significant (the Chi-square statistics was 59.533 and 70.307 , respectively, for each of which the p-value was 0.000 ), the IPO model was insignificant (Chi-square 31.514, p-value 0.139). There was no significant variable in the IPO model. Insignificance of the IPO model was due to the small number of IPO exits; observations of the results here are not conclusive.

The M\&A model and the Exit model were very similar to each other, differing only because the latter included the IPOs. Hence, the significance in the Exit model derived mainly from the M\&A model. Thus, it is the results of the estimation of the M\&A model that are mainly discussed here.

- Entrepreneurial firms in the IT sector had a significantly shorter time to an M\&A (p-value $=0.066$ ). This may be a manifestation that product development takes a relatively shorter time in the IT sector, especially compared to that in the Life Sciences (Lerner, 1994b; Cumming and MacIntosh, 2001b; Giot and Schwienbacher, 2006). Alternatively, the analysis covers the period after the Internet Bubble: when many venture capitalists may have exited their IT investments in a hurry to adapt their investment strategies to the change in climate of the IT industry.

- The "foreign" category of the type variable behaved in a strange way: it was insignificant in the IPO model, insignificant with a large standard error in the M\&A model, and marginally significant in the Exit model. This is because there was no M\&A exit observation associated with this category. A syndicate formed 
mainly by foreign investors (or a foreign fund) investing in a Canadian company may be unable to monitor and add value to the company thoroughly due to the geographic barriers associated with a distant investment (Bruining, Verwaal, Lockett, Wright, and Manigart, 2006; Hopp and Rieder, 2006; Sorenson and Stuart, 2001; see II-2-2-2 and II-2-3-2). Alternatively, this result may be a consequence of dysfunctional conflicts among Canadian and foreign investors. The bottleneck hypothesis predicts that an entrant investor, coming from outside of the incumbents' community, is more likely to undervalue the incumbents' investments, which causes dysfunctional conflicts among investors lowering the probability of a successful exit.

- Quebec deals were less likely (p-value $=0.082$ ) to attain an M\&A. This, along with the results of previous analyses, suggest that: (1) there is a high level of syndication activity in Quebec; yet, (2) entrepreneurial firms in Quebec have a lower chance of a successful exit; and, (3) even when they attain a successful exit, they have received a significantly smaller amount of venture capital at the time of exit. As discussed in the previous subsection (V-2-1), this may reflect the facts that: (1) nine out of eleven very large funds in Quebec are non-private independent funds and hold a large number of portfolio companies (see Table IV4). ${ }^{257}$ This implies a high level of syndication activity in Quebec yet a small amount of capital infusion in each company; and, in particular, (2) three out of the

${ }^{257}$ Recall that Canadian large non-private independent funds hold significantly larger number of portfolio companies than the size-comparable American funds (see V-1-1-2). 
nine very large non-private independent funds (Fonds de solidarité (FTQ) National, Fonds de solidarité (FTQ) Regional, and FondActrion) are non-rent-aunion LSVCCs. These funds have an explicit mandate to create employment, and thus are less likely to pursue aggressively a successful exit of their investee companies (Hebb and Mackenzie, 2001; see II-1-2-5).

- The level of experience of the venture capital investor(s) was significantly negatively related to the hazard of an M\&A (p-value $=0.012$ ), i.e., the less experienced the investor(s), the more likely the attainment of an M\&A. This is contrary to expectation and may be a product of multicollinearity (size and experience are correlated, see Appendix IV).

- The size variable was significant. Entrepreneurial firms backed by a syndicate with one or more "very large" or "large" funds were significantly more likely (quickly) to attain an M\&A exit, as compared to those backed by mid-sized or smaller venture capital funds. The significance level was one percent for the "very large" category and five percent for the "large" category. This result is consistent with Hypothesis 7, which predicts that successful exits are more likely when investors are large. ${ }^{258}$

\footnotetext{
${ }^{258}$ Small funds are more likely to invest in companies at the early stage of their development, i.e., farther away from a successful exit than those at the later stage of their development. To control for this possibility, two measures of the investee's level of development were added in the model: the amount disbursed at, and the round number of, the financing round prior to the exit or the termination point of December $31^{\text {st }}, 2009$. They were, however, insignificant. Moreover, for a robustness check, the three models (Exit, M\&A, IPO) were estimated excluding from the sample entrepreneurial firms that received only one financing round. The results in respect to the size of investors are similar to those in Table V-17.
} 
- Moreover, the number of investors in the syndicate was significantly positively related to the hazard for an M\&A. Recall that the previous analysis (V-1-3-1) revealed that the total amount of venture capital infused was significantly positively associated with the number of investor, as well as the size of the largest fund in the syndicate. A larger amount of capital infusion is possible when many investors are involved, and/or one or more large investors is in the syndicate, which, in turn, speeds an M\&A exit. ${ }^{259}$ An alternative interpretation, however, is possible: venture capitalists' value-adding activities could be more effective and efficient when many investors are involved, which prompts an M\&A exit (see II2-2-2). However, there may be a limit to the positive impact of the number of syndicate members on the quality of the value-adding activities as too large a number of investors involved in a syndicate is likely to increase the cost of managing the syndicate and to generate agency problems among the investors (Lockett and Wright, 2001; Bruining, Verwaal, Lockett, Wright, and Manigart, 2006; Wright and Lockett, 2003; and Cumming, 2006; see II-2-5-4). This may suggest an inverse $\mathrm{U}$-shaped relationship between the number of investors in the syndicate and the quality of the investors' value-adding services (as the number of investors in a syndicate increases, the quality of the value-adding first increases, then decreases), and, therefore, between the number of investors and the

\footnotetext{
${ }^{259}$ This is also consistent with previous studies that find a positive association between the number of investors in a syndicate and the investee's hazard for a successful exit (Giot and Schwienbacher, 2006) as well as between a syndicated (as opposed to a standalone) investment and the investee's growth (Hopp and Rieder, 2006).
} 
probability of a successful exit (as the number of investors increases, the probability of a successful exit first increases, then decreases). However, the coefficients of the "number of syndicate members" categories show a linear-like relationship between the number of investors and the probability of an M\&A. This is more consistent with the interpretation that "more investors mean larger capital infusions and thus a sped up M\&A" rather than "more investors mean better value-adding and thus a sped up M\&A".

- The last size-related variable, the presence or absence of a (or more) foreign fund in the syndicate, was insignificant. As discussed earlier, this may be due to dysfunctional conflicts among investors brought on by the entry of a foreign fund to the syndicate, which slows down the investee's successful exit (the bottleneck hypothesis predicts that large foreign funds tend to undervalue the incumbent investors' interests when entering syndicates, most likely resulting in dysfunctional conflicts between early and later stage investors). Alternatively, this may be due to the multicolinearity among the three size measures. ${ }^{260}$

In sum, the results were consistent with Hypothesis 7: Successful exits were less likely when early investors were small funds. The size and the number of investors in the syndicate were significantly and positively related to the hazard of an M\&A exit. However, the small number of IPO observations and the resultant insignificance of the IPO model made Hypothesis 8 un-testable using only recent Canadian data. It must,

\footnotetext{
${ }^{260}$ Foreign funds are more likely to enter a syndicate with a large number of investors and/or a syndicate with one (or more) large fund (see Appendix V).
} 
therefore, be left for future research. (Nevertheless, given that Canadian funds are small (as compared with those of the United States), few IPOs in Canada are consistent with Hypothesis 8: Acquisition exits are more likely, as compared to IPO exits, when early investors are small). ${ }^{261}$

\section{2-3. Hypothesis 9 and 10}

Hypothesis 9: In terms of market capitalization or issue size at the time of their IPOs, firms backed by small venture capital funds are smaller than those backed by large fund.

Hypothesis 10: The price at which a portfolio company is acquired is lower for firms backed by small venture capital funds than those backed by large funds.

The original plan for testing the above hypotheses was to run two OLS regression models, one for IPOs, the other for M\&As. The dependent variable was exit prices (the performance adjusted issue size for IPOs, the performance adjusted purchased price for M\&As) and explanatory variables, including the size of the venture capital investors. However, the issue size was only available for seven IPOs, and the purchase price for only 28 M\&As. These small numbers of observations rendered the proposed empirical analyses tenuous.

\footnotetext{
${ }^{261}$ The original plan was to compare the coefficient estimate of fund size in the IPO model with that in the M\&A model, using a one-degree-of-freedom Wald chi-square statistic for testing the null hypothesis that the two coefficients are equal (alternatively, a multinomial logistic regression estimate among IPO exits, M\&A exits, and not exited).
} 
Moreover, the large numbers of missing data for exit prices suggest the presence of selfreporting bias. The fact that there was a considerable number of missing values for exit prices may imply that venture capital funds report the exit prices of the exited investment only when they are reasonably high. ${ }^{262}$ The two hypotheses presented above are therefore left as areas for future research. ${ }^{263}$

\section{2-4. Hypothesis 11}

Hypothesis 11: The effects of capital constraints specified in Hypothesis 6, 7, 8, 9 and 10 are more likely to manifest in a community or industry comprised of small funds than in a community or an industry of large funds.

The original plan for testing Hypothesis 11 was to add a variable, namely the percentage of large funds for the incumbents' community, to the regression models employed for Hypothesis $6,7,8,9$ and 10 . More specifically, it was planned that: (1) for each year, the proportion of funds accounted for by large funds (the amount of capital under management greater than or equal to $\$ 165$ million $\mathrm{CDN}$ ) would be calculated for each of Ontario, British Columbia, Quebec, and the Prairies and the Atlantic provinces; (2) the regression models would be re-estimated with this "percentage-of-large-fund" variable (and without the location variable, which, by definition, would be strongly correlated with the new variable).

\footnotetext{
${ }^{262}$ The Thomson Financial VCReporter database is based on the venture capitalists' spontaneous reports on their investments.

${ }^{263}$ Another reason is no performance data is publicly available for entrepreneurial firms exited via M\&As.
} 
However, in hindsight, a deficiency was recognized in the design of the analysis described above. Because for each province the proportion of funds accounted for by large funds is relatively constant over the years, the "percentage-of-large-fund" variable is, for all practical purposes, almost identical to the location variable. ${ }^{264}$

Nevertheless, the analysis was carried out as it was originally planned (the percentage-oflarge-fund variable was added to model 6 and 7 (for Hypothesis 6 and 7, respectively) and the estimations were re-run). The results are summarized as follows:

- Hypothesis 6 (OLS regression on the total amount of venture capital received by the investee by the time of the exit). Recall that it was found that: (1) Quebec is the province where most of the large funds are located; and, (2) when the investee and most investors are located in Quebec, the investee receives a significantly smaller amount of venture capital by the time of its exit than for other regions. When the percentage-of-large-fund variable was included in the regression, it was negative and significant ( $\mathrm{p}$-value $=0.000$ ) simply because it detected this "Quebec" effect. When the estimation was run with the sample excluding the Quebec observations, the percentage-of-large-fund variable was insignificant (p-

\footnotetext{
${ }^{264}$ The proportion of large funds was calculated on a number of funds base since the focus of this study is the availability of large funds as a syndicate partner (as an additional source of capital). Even if this variable is calculated based on the amount of capital under management, it is still almost identical to the location variable, and thus the deficiency of this variable remains.
} 
value $=0.377) .{ }^{265}$ The inclusion of the percentage-of-large-fund variable does not materially alter any of the previous conclusions (see Appendix VI).

- Hypothesis 7 (Proportional Hazard Models on time to exit/M\&A/IPO). The percentage-of-large-fund variable is insignificant (p-value $=0.389,0.533,0.115$, respectively) ${ }^{266}$ The inclusion of the percentage of the large fund variable does not materially alter any of the conclusions. ${ }^{267}$

The effect of the industry structure should probably be examined as part of a thorough international (or interprovincial, if possible) comparison of venture capital industries. Such a comparison would be in a position to consider the various aspects of venture capital communities (legal, cultural, institutional, etc.) and to examine the impacts of those factors, along with the industry structure factor (the percentage of large fund, etc.) on a community's syndication activities and exit practice. In this context, Jeng and Wells (2000) have studied the impacts of legal and economic factors on countries' venture capital fundraising and investing. Cumming, Schmidt, and Waltz (2006) have examined the relationship between legality and venture capital investment activities, and Cumming, Fleming, and Schwienbacher (2006) have investigated the impact of legality on exiting venture capital investments. However, no existing research has carried out an

\footnotetext{
${ }^{265}$ Specifications that include the interaction term between the size and the percentage of large funds were also attempted. The results were the same: the interaction term just replaced the Quebec deal variable. When the sample excluded the Quebec observations, the interaction term was insignificant.

${ }^{266}$ The above p-values are for samples including the Quebec observations. When the Quebec deals were excluded, they were $0.788,0.648,0.908$, for the exit, M\&A and IPO models, respectively. For the sake of brevity, the tables showing the regression results are not included here but are available upon request.

${ }^{267}$ Specifications that include the interaction term between the size and the percentage of large funds were also attempted; the interaction term was insignificant while other results remained unchanged.
} 
international comparison of the impact of the industry structure on a country's venture capital activity while taking other legal and economic factors into account. This remains an important area for future research.

\section{2-5. Summary of Results of Exit Analyses}

The results of the analyses on the Canadian venture capital exit practice are summarized as follows:

- The total amount of venture capital infused into an exited entrepreneurial firm (by the time of its exit) significantly increases when it is backed by: (1) a larger number of investors; or, (2) by one or more large funds. This is consistent with Hypothesis 6, which predicts a smaller amount of venture capital infusion to an entrepreneurial firm backed by small funds;

- The hazard for a successful exit was significantly related to the size of the investor(s). ${ }^{268}$ Entrepreneurial firms backed by a syndicate with one or more "very large" or "large" funds or by a large number of small investors were significantly more likely to attain an M\&A exit over a given time. These results are consistent with Hypothesis 7, which predicts that successful exits are more likely when investors are large, and thus a large amount of capital infusion is possible. The

\footnotetext{
${ }^{268}$ This is measured as time to M\&A. Recall that the observation regarding the small number of IPOs led to inconclusive results of the analysis of time to IPO.
} 
positive and significant relations between the total amount of venture capital infused and the size, as well as the number of investors, further supports this hypothesis;

- The presence of one or more foreign funds in a syndicate was not significantly related to the total amount of venture capital infused into the investee by the time of its exit, nor with the hazard for the investee's successful exit. This may be because of the multicolinearity among the three measures for the size of the investors (the size of the largest fund, the number of investors, and the presence or absence of a foreign fund in the syndicate). They are correlated in such a way that foreign funds are more likely to be part of a syndicate with a large number of investors or with a syndicate with one or more large funds (see Appendix V).

- The analyses of this study consistently observed a significant difference between Quebec and the other provinces in Canada. More specifically, (1) Quebec has higher syndication activities (a higher probability of adding a new (large, in particular) investor and a larger number of investors in a syndicate); yet, (2) when the investee and most investors were located in Quebec, the investee had a significantly lower probability of a successful exit; and, (3) the total amount of venture capital infused by the time of the exit was significantly lower. This probably reflects the presence of large funds, non-rent-a-union large LSVCCs in particular, in Quebec. 


\section{Robustness Checks}

A number of alternative approaches were attempted in the analyses described in the previous sections of this chapter; many of these were mentioned in sections 1 and 2 (mainly in the footnotes). However, there are still several checks for robustness that were carried out but have not yet been mentioned. This final section of chapter $\mathrm{V}$ discusses these robustness checks.

Because the focus of this study is the effect of size on venture capital syndication and exit practices, how best to measure the size of a syndicate is important to the analyses. Accordingly, the first subsection discusses the approach this study employed to measure the size of a syndicate as well as the alternative approaches used for robustness checks. The second subsection introduces alternative measures for other variables, also used for robustness checks.

\section{3-1. Size Measures}

This study examines the impact of the size of a venture capital fund on its syndication activity and investment exit outcomes. As venture capital deals are, in many cases, syndicated, the methods used to measure the size of a syndicate - the size of multiple venture capital funds collectively - is important, therefore, to the analyses. However, the estimation of the size of a syndicate is problematic. For example, previous studies (e.g., 
Barry et al., 1990; Lerner, 1994b; Gompers, 1996) assume that the lead investor is the one that characterizes the syndicate, and so they use attributes (such as age, size, type, and location) of the lead investor to describe the syndicate. However, the Thomson Financial VCreporter database does not identify the lead investor in a syndicate; nor does the database contain the type of information (such as relative amounts invested by the syndicate members or venture capital investors who sit on the board of directors) that could help identify the lead investor. ${ }^{269}$

Given the limitations of the data, and following Lerner (1994b), this study assumes the largest venture capital fund to be the lead investor and uses the size of that fund as a proxy for the size of the syndicate. Larger funds tend to invest a greater amount per deal (recall the positive and significant correlation between the size and the average amount invested per deal, revealed in V-1-1-1). Thus, it is likely that larger funds have larger equity stakes in investee companies (arguably, more likely to be the lead investor), and their presence in a syndicate increases the amount of capital available to the investee firm.

It goes without saying, however, that this approach ignores other investors in the syndicate. Accordingly, two additional variables are included in the analyses: the number of syndicate members and the presence of one (or more) foreign fund. A larger number of investors involved in a deal means that capital can be gathered from a larger number of

\footnotetext{
${ }^{269}$ Barry et al. (1990) use the venture capital fund with the largest equity stake in the investee firm to characterize the syndicate (i.e., they assume such a fund to be the lead investor). Gompers (1996) classifies the venture capital firm that has been on the board the longest as the lead venture capitalist.
} 
sources. Thus, the size of a syndicate is assumed to be greater when it consists of many venture capital funds. It is also assumed that the presence of a foreign (mostly American) fund in a syndicate increases the amount of capital that can be infused by the syndicate. Recall that the average amount of capital under management is significantly larger for American funds than for the Canadian counterparts (see V-1-1-2). Also, foreign (American) funds making cross-border investments are presumed to be large. ${ }^{270}$

In sum, the size of a syndicate was gauged by three measures: (1) the size of the Canadian funds measured by the size of the largest (Canadian) fund in the syndicate, ${ }^{271}$ (2) the presence or absence of one (or more) foreign fund in the syndicate; (3) the number of funds in the syndicate. ${ }^{272}$ Nevertheless, this approach is not limitation-free: as noted above, this approach ignores the size of the other (Canadian) funds. Accordingly, three alternative measures for the size of the Canadian funds were employed. (These alternative measures replaced the original measure and were included along with the presence of foreign fund and the number of funds in the syndicate variables). These alternative approaches were:

\footnotetext{
${ }^{270}$ Experienced venture capitalists (which are presumably large) are more likely to have a wider geographic scope for their investments (Sorenson and Stuart (2001; see II-2-3-2).

${ }^{271}$ The size of the Canadian funds variable was then categorized into quintiles (very small, small, middle, large, very large). For a robustness check, several different categorization schemes were also attempted; including: three levels (small, middle and large), four levels (very small, small, middle, large, or small, middle, large, very large, etc.). This is to make sure that the results obtained with the original scheme are not an artefact of the categorization used there. The results with different categorizations did not materially differ from those with the original categorization.

${ }^{272}$ Both a natural number variable and several categorical transformations were attempted. The results were the same.
} 
1. A categorical variable with five levels: 1.0 if the majority of funds are very small, 2.0 if the majority is small; 3.0 for middle-sized, 4.0 for large, and 5.0 for very large.

2. Four continuous variables: the percentage of: (1) very large; (2) large; (3) small; (4) very small; funds in the syndicate. ${ }^{273}$

3. Five dummy variables: the first dummy takes the value 1.0 if there is at least one very small fund in the syndicate ( 0.0 otherwise); the second takes 1.0 if there is at least one small fund; the third is 1.0 if at least one middle-sized fund; the fourth is 1.0 if at least one large fund; the fifth is 1.0 if at least one very large fund.

These alternative measures have the advantage that they consider the sizes of all the funds in the syndicate. However, they also have limitations. For example, the first measure regards the following two syndicates as the same size: one that consists of five small funds and one very small fund; and, a syndicate that consists of five small funds and one very large fund.

The shortcoming of the second measure is that the effect of a size category is diluted when the syndicate has many investors. Consider the following two syndicates: A consists of five small funds and one very large fund; B consists of one small fund and one very large fund. Both syndicates successfully bring the investee to an IPO exit. The value of the percentage of the very large funds is 16.7 percent for $\mathrm{A}$, and 50 percent for $\mathrm{B}$. Then, the regression analysis may yield an insignificant coefficient for the percentage of

\footnotetext{
${ }^{273}$ The percentage of mid-sized funds is redundant. Some categorical transformations were also attempted.
} 
the very large fund variable, as it does not detect a significant positive relationship between the percentage of the large funds and the likelihood of an IPO.

The third measure addresses the shortcoming of the second measure. However, the third measure is limited in that it regards a syndicate consisting of five very large funds and a syndicate consisting of one very large fund as being the same size. Moreover, it is likely that the five dummies are correlated with each other. For example, it is possible that: (1) small funds are more likely to partner with very large funds; and, (2) syndicates with one (or more) very large fund are more likely to bring the investee to a successful exit. Then, the regression analysis may yield a significant positive relationship between the presence of a small fund and the probability of a successful exit.

Nevertheless, all the analyses were re-estimated using the alternative measures for the size of the Canadian funds in the syndicate. In no case did the use of the alternative measures materially change the conclusions reported previously. ${ }^{274}$,

\section{3-2. Other Robustness Checks}

Type, location and level of experience of the syndicate

\footnotetext{
${ }^{274}$ Both the original and the alternative measures for the size of the Canadian funds in the syndicate led to the same conclusion but the effect of the size was most clearly manifested when the original measure was used. This is probably due to the shortcomings of the alternative measures discussed above. Also, the finding that the original measure detects the size effect most clearly may suggest that what matters most is the presence or absence of one or more (very) large funds, that is: the capital availability of a syndicate depends on the size (capital availability) of the largest fund in the syndicate.
} 
In the original approach, the type of the syndicate and the location of the deal were determined based on the type (location) of the funds that formed the majority of funds in the syndicate. The alternative approach is to define type and location using the type and location of the most experienced venture capital fund in the syndicate (assuming that the most experienced venture capital fund is the most influential in the syndicate). However, there exist a number of ties in the experience variables (for example, 27 of the 373 funds in the analyses have management companies founded in 1999 - these 27 all have, therefore, the same value for the "age of the venture capital firm" variable), making it infeasible to determine the most experienced fund in the syndicate. Thus, this alternative approach was omitted.

Also, it was reported in the descriptive statistics (IV-2-3) that the six largest Canadian funds participated in 38.4 percent of all venture capital transactions used for the analysis. This means that, because these big six are managed by older venture capital firms, a large number of syndicates have the same value for the experience variables. Because the six big funds invest in so many entrepreneurial firms, it seems likely that they are not closely involved in each of their investee firms. This suggests that measuring the level of experience using the most experienced venture capital funds, together with the big six funds, might be misleading.

To address this point, the level of experience of the syndicate was alternatively measured by the most experienced venture capital fund in the syndicate, excluding the big six funds (that is: a big six fund in a syndicate is not counted when the experience of the syndicate 
is measured). However, this generated a large number of missing observations for experience variables because a large number of syndicates were formed exclusively by those big six. Exclusion of the deals that were made solely by big six funds not only shrank the sample size but also introduced a serious bias in the sample (it deteriorated the entire picture of the Canadian venture capital investment activity). Therefore, this alternative approach was also omitted.

\section{Location of the deal}

In the original regression models, the location variables consider both the investors' and the investee firm's location. ${ }^{275}$ It is a categorical variable with five levels: Ontario, British Columbia, Quebec, the Prairie and Atlantic provinces, and other, and a deal is classified in a particular category, say, Ontario, when the following two conditions are met: (1) the location of the majority of the funds that form the syndicate is Ontario; and, (2) the location of the investee firm is Ontario. In other words, a deal is categorized in "other", when: (1) there is a tie in the location of the funds that form the majority of the syndicate (e.g., two in Ontario, two in Quebec); or, (2) the location of the funds that form the majority of the syndicate and the location of the investee are different. An alternative definition, which simply uses the location of the investee as the location of the deal, was also attempted. In no instance were the empirical results materially different from those reported.

${ }^{275}$ Except for Model 2, in which the location was defined as the province in which the investee firm is situated. This is because the above-described way of defining location generates a category "other", which includes ties (e.g., deals with two funds in Ontario and two in Quebec), which are by definition correlated with the dependent variable (sole versus syndicated investments). 


\section{Natural Logarithm Transformations and Categorization}

Continuous (or natural number) variables, including the four measures of the investor's (the syndicate's) experience (the age of the venture capital firm, the number of funds raised, the number of entrepreneurial firms invested, and the number of exits attained) were included in a variety of forms: as a form of a natural number, a natural logarithm transformation and a categorical transformation. The log and categorical transformation did not generate a result that materially differed from those reported in sections one and two. 


\section{CONCLUSION}

This chapter concludes this thesis with a summary of the research and a discussion of the results. The first section reviews the main findings in relation to the predictions of the bottleneck hypothesis. This is followed by a consideration, in section two, of the work's implications for the academic literature, for practitioners, and for policy makers. The third section discusses the limitations of the work and identifies potential areas for future research.

Overall, the empirical observations obtained in this study are consistent with the view that the Canadian venture capital sector is bottlenecked. Coupled with the phase-out of labour-sponsored venture capital funds, the results suggest the need for an overhaul of the entire sector. To be sure, there remain many issues to be resolved and other research questions to be addressed in order to determine the optimal path towards an ideal Canadian venture capital sector.

\section{Main Findings in relation to the Bottleneck Hypothesis}

This dissertation advances, and empirically tests, the thesis that the structure of the Canadian venture capital industry is bottlenecked. More specifically, this structure, being comprised of a large number of relatively small funds and a small number of relatively 
large funds, is an important factor in the increasing reliance on foreign venture capital, syndication dynamics that differ from those in the United States, and the lower successful exit rates of Canadian venture capital investments. The following points summarize the key findings of this study in relation to the predictions of the bottleneck hypothesis.

1. Consistent with the first prediction of the bottleneck hypothesis, namely that small fund size limits the total funding that a venture capital fund can allocate to a given enterprise (Hypothesis 1), is the finding that the size (the amount of capital under management) of a venture capital fund is significantly positively related to the level of capital availability of the funds.

2. The second prediction of the bottleneck hypothesis was that: (1) because a small fund is limited in the amount of capital it can allocate to each of its investee firms, it may not by itself have sufficient capital to take investees to an optimal exit; (2) as growth of the investee firm demands ever larger rounds of financing, the above capital constraint on the fund may oblige the investee firm and the venture capital investors to seek additional sources of capital (Hypothesis 2, 3, 4, 5a). Several empirical observations consistent with this prediction were obtained, including: 
a. Syndicates comprised of small funds are relatively more likely to add a new fund to the syndicate, and the fund added to the small syndicate is likely to be larger than the incumbent funds. ${ }^{276}$

b. Syndicates comprising one (or more) foreign fund are significantly less likely to add a new investor relative to purely domestic syndicates.

The probability of a new fund entry, as well as the probability of the entry of a new fund larger than the incumbent investors, increases as the investee firm grows. In addition, the number of syndicate members also increases with the growth of the investee.

3. Because the Canadian venture capital industry is comprised of a large number of small funds, most of which need to seek additional sources of capital, the bottleneck hypothesis predicted a high level of syndication activity in Canada. The empirical evidence supports this prediction: For more than half of all Canadian funds, all of their investments were syndicated and for almost 90 percent of funds syndicated more than 60 percent of their deals (as of December 2009). These numbers are considerably higher than those exhibited for German venture capital funds (Hopp and Rieder, 2006). Moreover, it was observed that:

\footnotetext{
${ }^{276}$ However, this result may simply reflect the absolute number of potential syndicate partners for funds in each size category. That is: small funds have a large number of potential syndicate partners that are larger than they are; and large funds have a large number of potential syndicate partners that are smaller than they are.
} 
a. Large Canadian funds maintain a disproportionately large number of entrepreneurial firms in their portfolios relative to comparably-sized American funds;

b. The number of investors per financing round is significantly larger in Canada than it is in the United States. The impact of a dollar increase in investment size on the number of investors is greater for Canadian deals than for American deals.

These results suggest that, in Canada, the relatively small number of large funds is sought after by the large number of small funds. This leads to many more investments in large funds' portfolios than in the United States. The outcome is a high syndication propensity, not only for small funds but for large funds as well. $^{277}$ This means that Canadian funds' financial capital, as well as fund managers' ability to add value to investees, is spread so thinly that each incremental investment round requires a greater number of syndicate partners in Canada than it does in the United States.

4. The fourth prediction of the bottleneck hypothesis was that the relative scarcity of large funds in the Canadian financial sector obliges small funds to seek venture capital investors from outside Canada (Hypothesis 5b). It was observed that syndicates comprised of very small funds are significantly more likely to add a

${ }^{277}$ No significant difference in propensity to syndicate was detected between small and large funds. 
foreign fund, and that foreign fund entry is most likely to occur during later financing rounds when the investee's need for capital is highest.

5. Finally, the bottleneck hypothesis delineated three reasons why small funds are disadvantaged in attaining a successful exit - especially when they are in a community lacking large funds. The three reasons are:

a. Searching for additional financing is costly and diverts the founder's and investors' time and energy away from the development of the entrepreneurial firm;

b. If an additional syndicate partner(s) cannot be found, small incumbent funds' limited financial availability is likely to be transferred to the investee's underinvestment problem;

c. Entrant investors are, arguably, able to drive down the valuations of the incumbent investors' investments, especially when the incumbents must rely on a source of capital that is from beyond their immediate community. This may reduce the motivation and efforts of the founding team and bring about dysfunctional conflicts within the governance team, both decrease the likelihood of success. ${ }^{278}$ Alternatively, to avoid conflicts and undervaluation, the incumbents and the entrepreneur may decide to

\footnotetext{
${ }^{278}$ Even if the entrant's undervaluation does not occur, costs associated with managing the syndicate increases if it consists of a large number of investors, which could negatively affect investors' activities to contribute their non-financial capital to the investee (see II-2-5-4).
} 
sell the firm prematurely, leading to relatively more M\&A exits and fewer IPOs.

Consistent with this expectation, it was found that entrepreneurial firms backed by small venture capital funds are significantly less likely to attain a successful exit. Moreover, the total amount of venture capital infusion received by an exited entrepreneurial firm by the time of its exit is significantly smaller when it is backed by small funds or by a smaller number of investors (or both). ${ }^{279}$

Taken together, the empirical evidence obtained here is consistent with the view that the Canadian venture capital industry is bottlenecked. The following section discusses the implications of these results.

279 Another finding suggests the possibility that Canadian entrepreneurial firms are underinvested when backed by small funds. That is, while fund size is significantly positively related to an average amount invested per financing round, it is not significantly positively related to the number of portfolio companies when only private independent funds are considered in the analysis. This suggests that Canadian private independent partnerships increase the amount they invest per financing round rather than the number of entrepreneurial firms in their portfolios when they raise more capital, which implies that Canadian entrepreneurial firms may not receive sufficient financing to support firm owners' growth aspirations when backed by small funds. 


\section{Implications of the Results}

The results of this study have several implications for the academic literature, for practitioners, and in particular, for policy makers who seek to activate the Canadian venture capital sector. These implications are discussed in turn in the following three subsections.

\section{2-1. Implications for the Academic Literature}

Previous research has found, as did this study, a positive association between fund size and performance. Yet, the interpretations of this finding differ. Kaplan and Schoar (2005) explain this association as successful past performance enabling venture capitalists to raise large funds. Laine and Torstila (2003) attribute the positive association to the idea that larger funds are better able to fund more attractive opportunities because they are exposed to a larger universe of investments. The findings of this study, however, are more in line with Murray's hypotheses that small funds are financially constrained and disadvantaged due to scale and scope economies and that the fund size itself - that is, the level of financial availability - significantly influences the fund's syndication behaviours and its investment outcomes (Murray, 1999, 2007; Murray and Marriott, 1998; and Dimov and Murray, 2006). 
This suggests that when venture capital syndication practice and exit behaviours are examined, the influence of the pure size effect - the effect of financial availability of the fund - must be taken into account. It is, of course, likely that size contains information related to the level of experience of the fund managers, and the degree of exposure to investment opportunities from which the fund is able to choose (in fact, this study found significant correlation between size and each of the four experience variables, as well as between size and the number of portfolio companies). However, this does not mean that size does not also carry information about the degree of financial capability of the fund.

As mentioned above, the situation in Canada is not unique. Reliance on foreign funds and small investment fund size were also reported in other countries. Moreover, the effect of the financial capability information contained in fund size may also be present in other venture capital markets, and thus remains an inevitable element to be taken into consideration in an investigation in those markets (Bygrave and Quill, 2007; Hopp and Rieder, 2006; Murray, 1999; see I-2-3). This study has demonstrated mechanisms through which capital constraints on a fund influence syndication practices and exit outcomes. This may well lead to a better understanding of syndication and exit practices in other countries. 


\section{2-2. Implications for Entrepreneurs}

The empirical observations show that it is better for entrepreneurs in Canada to be backed by large funds, especially large private independent funds if their businesses are to grow and be successful. ${ }^{280}$ However, this information would be useless taken as a message unless the market were to become competitive among venture capital investors for promising investment opportunities - and this seems unlikely in the current context of the Canadian venture capital market. In Canada, the flow of venture capital is minute relative to the flow of commercial loans (and is progressively declining, especially for early-stage firms). ${ }^{281}$ Canadian entrepreneurs are probably not in a position to choose funds from among those that offer venture capital financing.

The results of this study, then, may help Canadian entrepreneurs to understand the current nature of venture capital investments in Canada and to anticipate the activities that tend to occur after receiving the initial financing rounds. As their businesses grow successfully, they may have to spend much of their time and efforts searching for additional sources of financing while managing the company with a limited amount of human and financial capital. Until the Canadian venture capital market has been restructured such that

\footnotetext{
${ }^{280}$ Large private independent funds tend to have more capital available than large non-private independent (such as government and government-affiliated) funds.

${ }^{281}$ For example, in 2004 , when almost $\$ 900$ billion was authorized in various forms of commercial loans to more than 1.8 million small- and medium-sized businesses (Industry Canada, http://sme-fdi.ic.gc.ca), the flow of institutional venture capital was less than $\$ 1.5$ billion (Canadian Venture Capital Association, CVCA, 2009) and the estimated annual flow of business angel financing was $\$ 2.2$ billion (Riding, 2008). In 2009 , the flow of venture capital investment had fallen to $\$ 1.0$ million and two-thirds of that was in the form of follow-on investments (Canadian Venture Capital Association, CVCA, 2009). Thus, commercial loans appear to be an important source of financing for Canadian young, growing innovative firms, although it is sometimes argued that commercial loans may not be an appropriate source of capital, and venture capital may be more suited, for such firms (Brierley, 2001).
} 
promising businesses can receive a sufficient amount of financing for their growth at appropriate valuations and without undue syndication, entrepreneurial teams may have to face a trade-off between accepting foreign funds' financing offers (often with unfavourable conditions or lower valuations of the company), on the one hand, and selling their businesses prematurely to a large corporation on the other.

\section{2-3. Implications for Policy Makers}

The results of this research are consistent with the view that the structure of the Canadian industry is an important factor in the increasing reliance on foreign venture capital, syndication dynamics that differ from those in the United States, and the lower successful exit rates of Canadian venture capital investors. If the Canadian venture capital sector is indeed bottlenecked, as the results of this study suggest, a restructuring of the sector is necessary. That is: one way to activate the Canadian venture capital sector would be to redesign the industry such that more large funds can be created in Canada.

However, there are several other issues associated with the Canadian venture capital sector that need to be taken into consideration. These include: the relatively high level of LSVCC funds' activity and the low level of private independent funds' activity; the lower levels (compared with the United States) of involvement of financial institution investors; the lack of experience and industry knowledge of fund managers; and the lack of management skills of the entrepreneurs (see II-1-3). These issues appear to be related not 
only to the structural issues of the Canadian sector, but also to each other. Simply creating funds of large financial availability without a simultaneous approach to the other problems may not work, or may even prove to be counterproductive. Moreover, just the creation of large funds alone has questions that need to be considered. For example, would the large funds be established through a government initiative? With what type of operation (private, hybrid, government or government-affiliated funds) would those funds be created?

In seeking answers to these questions, this research observed important implications in the venture capital activity in Quebec. This subsection, therefore, first discusses the Quebec case study (2-3-1) and then considers effective paths towards stimulating an active Canadian venture capital industry while taking into account the other issues mentioned above (2-3-2).

\section{2-3-1. Quebec Phenomenon}

Venture capital patterns in Quebec exhibit interesting results. First, syndication levels in Quebec are significantly higher than in other Canadian provinces in terms of the probability of a new investor entry (in particular, of a new large investor entry) and of the number of syndicate members in a deal. However, entrepreneurial firms located in Quebec, and backed primarily by Quebec investors, display a significantly lower probability of reaching a successful exit. Moreover, those Quebec entrepreneurial firms 
that did exit had received significantly smaller amounts of venture capital by the time of their exits (even after controlling for the size of syndicates)..

The previous chapter pointed out the followings as factors that collectively, possibly explain the above seemingly enigmatic results associated with Quebec.

- Quebec has a relatively large number of venture capital funds and is the province with the majority of large funds (the largest six venture capital funds in Canada are all located in Quebec). It appears that the presence of large funds, available as potential syndicate partners, leads to a high rate of syndication activity in Quebec. Quebec's higher level of syndication activities arguably reflects its industry structure. As previously mentioned,

- However, the majority of large funds in Quebec (nine of the eleven large funds with capital under management of at least $\$ 165$ million $\mathrm{CDN}$ ) are not private independent funds. This research found that large non-private independent funds hold, on average, many more portfolio companies than similarly-sized American funds. This implies that while the funds appear large in terms of total capital under management, the capital - as well as the mentoring and value-adding activities of the fund managers - is spread so thinly that the funds behave as if 
they were small. This is likely to limit the investee's chance to attain a successful exit. $^{282}$

To confirm this point, Table VI-1 ranks the 29 largest venture capital funds listed in Table IV-4 by the amount of capital per investee firm in ascending order. Almost all of the six out of the nine large non-private independent funds in Quebec are in the smallest tertile (note that those are government/government-affiliated funds). Thus, because large funds are so sought after by small funds as syndicate partners, they hold a relatively large number of portfolio companies but with limited financial capacity for each investee. While this seems to be Canada-wide, Quebec appears to be an extreme example.

As mentioned in the previous chapter, there is another factor for the Quebec phenomenon (i.e., the presence of large funds in the province is translated into a high syndication activity yet not translated into a large amount of capital infusion in each entrepreneurial firm and an increased likelihood of its successful exit). Three of the nine very large non private independent funds in Quebec are non-rent-a-union LSVCCs (Fonds de solidarité (FTQ) National, Fonds de solidarité (FTQ) Regional, and FondActrion). Table VI-1 shows that those funds have a particularly large number of portfolio companies, relative to the amount of capital under management. Fonds de solidarité (FTQ) Regional has the smallest amount of capital per investee firm ( $\$ 0.35$ million $\mathrm{CDN})$ among the 29 largest

${ }^{282}$ Recall that the syndicate size is significantly positively related with the amount of venture capital infusion as well as the hazard of a successful exit. 
Canadian funds. ${ }^{283}$ FondAction, the eighth largest venture capital fund and the second largest LSVCC in Canada, is ranked the $9^{\text {th }}$ smallest fund (among the 29) in terms of capital availability per firm ( $\$ 3.19$ million CDN per firm). Fonds de solidarité (FTQ) National, the second largest venture capital fund and the largest LSVCC in Canada, is ranked the eleventh smallest fund with the amount of capital per investee of $\$ 5.6$ million $\mathrm{CDN}$, while the average amount of capital per investee (among the 29 large funds) is $\$ 18.9$ million CDN.

These funds, which dominate the Quebec venture capital landscape, have an explicit mandate of job retention/creation, regional economic development, improvement of worker environment, etc., and tend to invest in small-and medium-sized businesses in traditional labour intensive sectors such as manufacturing (Hebb and Mackenzie, 2001; see II-1-2-5). These mandates are probably among the major factors why these funds hold a large number of investee firms in their portfolios and their tendency to be less likely to pursue aggressively a successful exit of their investee companies by making a large capital infusion in a few promising entrepreneurial firms.

According to Hebb and Mackenzie (2001), those non-rent-a-union LSVCC funds have worked effectively to attain their own objectives of job creation, etc., providing positive impacts on Quebec society and economy. It is therefore misleading to say that the

\footnotetext{
${ }^{283}$ Fonds de solidarité (FTQ) Regional, with 17 regional offices, focuses on companies located in regions outside Montreal, which require between $\$ 50,000$ and $\$ 500,000 \mathrm{CDN}$ of investments.
} 
Quebec government initiative to create those LSVCC funds is a failure, even if the presence of those funds is one of the major factors of the Quebec phenomenon. ${ }^{284}$

Nevertheless, the Quebec case study contains a valuable insight. That is: simply creating large venture capital funds may not be the best means of improving the effectiveness of the Canadian venture capital sector through better performances in terms of higher rates of returns and successful exits (as opposed to higher rates of job creation and other objectives non-rent-a-union LSVCCs typically have). ${ }^{285}$

\footnotetext{
${ }^{284}$ As mentioned in II-1-2-5, because those non-rent-a-union funds are significantly different from venture capital funds in general, whether it is reasonable to regard this group of funds as a category of "venture capital" funds is debatable.

${ }^{285}$ Hebb and Mackenzie (2001) claim that LSVCCs that deliver collateral benefits (non-rent-a-union LSVCCs) have greater returns on average than those within the same asset class that do not deliver such benefits. A further investigation that conducts a thorough comparison of performance (in terms of rates of returns) across different types of venture capital funds is, however, necessary in this regard.
} 
Table VI-1: 29 Large Canadian Funds ranked by Capital Availability

\begin{tabular}{|c|c|c|c|c|c|c|}
\hline Fund Name & Type & Mgmt Company & Location & $\begin{array}{l}\text { Cap under } \\
\text { Mgmt (in } \\
\text { millions) }\end{array}$ & \# of PC & $\begin{array}{l}\text { Capital per PC } \\
\text { (in millions) }\end{array}$ \\
\hline $\begin{array}{l}\text { Fonds de solidarité (FTQ), } \\
\text { Regional }\end{array}$ & LSVCC & $\begin{array}{l}\text { Fonds de solidarité des } \\
\text { travailleurs du Québec } \\
\text { (FTQ) }\end{array}$ & $\mathrm{QC}$ & 217.80 & 625 & 0.35 \\
\hline RoyNat Capital Inc. & Corporate Financial & Roynat Capital Inc. & ON & 298.00 & 303 & 0.98 \\
\hline $\begin{array}{l}\text { GrowthWorks Canadian } \\
\text { Fund Inc. }\end{array}$ & LSVCC & GrowthWorks Capital Ltd. & $\mathrm{BC}$ & 393.49 & 276 & 1.43 \\
\hline $\begin{array}{l}\text { Innovatech du Grand } \\
\text { Montréal }\end{array}$ & Government & Multiple Capital Inc. & QC & 350.00 & 221 & 1.58 \\
\hline $\begin{array}{l}\text { Working Opportunity } \\
\text { Fund }\end{array}$ & LSVCC & GrowthWorks Capital Ltd. & $\mathrm{BC}$ & 233.22 & 130 & 1.79 \\
\hline $\begin{array}{l}\text { BDC Venture Capital } \\
\text { Group }\end{array}$ & Government & $\begin{array}{l}\text { Business Development } \\
\text { Bank of Canada (BDC) }\end{array}$ & QC & 753.37 & 400 & 1.88 \\
\hline $\begin{array}{l}\text { Capital régional et } \\
\text { coopératif }\end{array}$ & Provincial VCC & Desjardins Capital de risque & $\mathrm{QC}$ & 827.37 & 312 & 2.65 \\
\hline $\begin{array}{l}\text { VenGrowth Investment } \\
\text { Fund II }\end{array}$ & LSVCC & $\begin{array}{l}\text { VenGrowth Private Equity } \\
\text { Partners Inc. }\end{array}$ & ON & 242.40 & 79 & 3.07 \\
\hline FondAction & LSVCC & FondAction & $\mathrm{QC}$ & 525.60 & 165 & 3.19 \\
\hline Victoria Park Capital & Government & Victoria Park Capital & SK & 300.00 & 92 & 3.26 \\
\hline $\begin{array}{l}\text { Fonds de solidarité (FTQ), } \\
\text { National }\end{array}$ & LSVCC & $\begin{array}{l}\text { Fonds de solidarité des } \\
\text { travailleurs du Québec } \\
\text { (FTQ) }\end{array}$ & $\mathrm{QC}$ & $4,110.00$ & 739 & 5.56 \\
\hline Ventures West 7 & Private Independent & $\begin{array}{l}\text { Ventures West Management } \\
\text { Inc. }\end{array}$ & $\mathrm{BC}$ & 235.00 & 33 & 7.12 \\
\hline Ventures West 8 & Private Independent & $\begin{array}{l}\text { Ventures West Management } \\
\text { Inc. }\end{array}$ & $\mathrm{BC}$ & 250.00 & 31 & 8.06 \\
\hline $\begin{array}{l}\text { VenGrowth Advanced Life } \\
\text { Sciences Fund }\end{array}$ & LSVCC & $\begin{array}{l}\text { VenGrowth Private Equity } \\
\text { Partners Inc. }\end{array}$ & ON & 150.00 & 18 & 8.33 \\
\hline
\end{tabular}




\begin{tabular}{|c|c|c|c|c|c|c|}
\hline Novacap II, LP & Private Independent & Novacap Investments Inc. & $\mathrm{QC}$ & 210.00 & 24 & 8.75 \\
\hline Manulife Capital & Institutional Investor & Manulife Capital & $\mathrm{ON}$ & 439.00 & 48 & 9.15 \\
\hline Summerhill Ventures I LP & Private Independent & $\begin{array}{l}\text { Summerhill Venture } \\
\text { Partners }\end{array}$ & ON & 175.00 & 17 & 10.29 \\
\hline EDC Equity Fund & Government & $\begin{array}{l}\text { Export Development } \\
\text { Canada }\end{array}$ & ON & 170.00 & 16 & 10.63 \\
\hline $\begin{array}{l}\text { CDP Capital Private } \\
\text { Equity }\end{array}$ & Institutional Investor & CDP Capital Private Equity & $\mathrm{QC}$ & $9,100.00$ & 797 & 11.42 \\
\hline $\begin{array}{l}\text { CDP Capital - } \\
\text { Communications }\end{array}$ & Institutional Investor & CDP Capital Private Equity & $\mathrm{QC}$ & $1,477.00$ & 111 & 13.31 \\
\hline $\begin{array}{l}\text { Celtic House Venture } \\
\text { Partners Fund III }\end{array}$ & Private Independent & $\begin{array}{l}\text { Celtic House Venture } \\
\text { Partners }\end{array}$ & ON & 280.00 & 19 & 14.74 \\
\hline $\begin{array}{l}\text { CDP Capital - Technology } \\
\text { Ventures }\end{array}$ & Institutional Investor & CDP Capital Private Equity & $\mathrm{QC}$ & $3,250.00$ & 195 & 16.67 \\
\hline $\begin{array}{l}\text { Celtic House Venture } \\
\text { Partners Fund II }\end{array}$ & Private Independent & $\begin{array}{l}\text { Celtic House Venture } \\
\text { Partners }\end{array}$ & ON & 375.00 & 21 & 17.86 \\
\hline $\begin{array}{l}\text { Clairvest Equity Partners } \\
\text { III L.P. }\end{array}$ & Private Independent & Clairvest Group Inc. & ON & 300.00 & 10 & 30.00 \\
\hline HSBC Capital Canada & Corporate Financial & HSBC Capital (Canada) Inc. & $\mathrm{BC}$ & 183.40 & 5 & 36.68 \\
\hline $\begin{array}{l}\text { RFG Private Equity LP } \\
\text { No.1 }\end{array}$ & Private Independent & Richardson Capital & MB & 325.00 & 8 & 40.63 \\
\hline Multiple Capital & Private Independent & Multiple Capital Inc. & $\mathrm{QC}$ & 350.00 & 8 & 43.75 \\
\hline $\begin{array}{l}\text { ARC Energy Venture Fund } \\
4\end{array}$ & Private Independent & ARC Financial Corporation & $\mathrm{AB}$ & 403.00 & 5 & 80.60 \\
\hline $\begin{array}{l}\text { ARC Energy Venture Fund } \\
3\end{array}$ & Private Independent & ARC Financial Corporation & $\mathrm{AB}$ & 310.00 & 2 & 155.00 \\
\hline
\end{tabular}




\section{2-3-2. Toward a More Effective Venture Capital Sector}

As seen in the previous sub-subsection, the Quebec case study contains a valuable insight. Simply creating large venture capital funds may not be the best means of improving the effectiveness of the Canadian venture capital sector through better performances in terms of higher rates of returns and successful exits. What is most important is to have a higher proportion of venture capital funds that have the financial capacity to provide large investments to each of their portfolio companies. This requires a change of approach from placing many small bets to placing fewer, but perhaps more strategic, large bets.

In this regard, it is helpful to explore further the factors that have led large non-private independent funds to have such a high number of entrepreneurial companies in their portfolios. While these large funds tend to hold a relatively high number of portfolio companies because they are sought after by small funds, the managers of these funds do have the discretion to either accept or reject a proposal for an investment. This suggests, therefore, that "being sought after" cannot be the only factor that causes the high number of portfolio companies held by large funds. Government, government-affiliated, and corporate-affiliated funds tend to have objectives, other than profit maximization, imposed upon them; but how those objectives are related to the high number of portfolio companies is not clear. It is also important to keep in mind that in the case of LSVCCs, statutory covenants restrict them to investing in small companies. At the time such constraints were put into effect, the perception was that Canada lacked early-stage 
venture capital. The findings of this thesis, however, do not support this view. This work found that Canada has a relative shortage of large funds; that is, of late-stage venture capital. Put simply, a large fund with a mandate to make small investments has no recourse but to make many investments (otherwise funds would stay idle). Moreover, making many investments dilutes all the other value-added activities that fund managers might provide, thereby reducing the likelihood of successful exits. Thus, it appears that, going forward, removing the requirement for small investments would be advisable. ${ }^{286}$

Also, it is necessary that the managers of the venture capital funds be selected carefully. Managers should have a good deal selection skills, such as an ability to identify viable high-potential business opportunities. They should also possess entrepreneurial and industry knowledge so as to be able to contribute value-adding activities to the investee firms. Recent studies, however, contend that Canadian general partners have relatively little experience and industry knowledge, especially managers of LSVCC funds (Duruflé, 2006; Cumming and MacIntosh, 2006; see II-1-2-5 and II-1-2-6). Acquiring this type of expertise is not straightforward; perhaps partnerships with foreign funds could provide the opportunity.

In a well-functioning venture capital market, the better performing funds are able to raise greater amounts of capital, which in turn allows them to make larger investments in a few

\footnotetext{
${ }^{286}$ This argument, however, may not be applied to non-rent-a-union LSVCC funds. As discussed in the previous sub-subsection and II-1-2-5, those LSVCC funds appear to play roles that venture capital funds in general are not usually expected to play, and, according to Hebb and Mackenzie (2001), they work effectively to fulfill their own mandates. The reasons why non-rent-a-union LSVCC funds hold a large number of portfolio companies are clear and consistent with their objectives.
} 
promising entrepreneurial businesses. It is therefore probably better for the Canadian venture capital sector to have large private independent limited partnerships. In this regard, the recent legislative changes, and those pending, in Ontario might work positively for the province's venture capital community. The Ontario government has reduced the percentage of the tax credit granted to investors in LSVCC funds and has announced further reductions over the next ten years. If, as Cumming and MacIntosh (2006) claim, the LSVCC funds have crowded out other forms of venture capital firms and decreased the overall supply of venture capital (see II-1-2-5), then returning the sector to a naturally competitive form, as it would be if there were no government intervention, would probably be an effective step towards the creation of a more active venture capital community. ${ }^{287}$

The problem with the above is that without intervention, change would come very slowly, if at all. The current record of rates of return on venture capital investment is dismal. Pension funds and other financial institutions cannot allocate funding to such investments while still respecting their fiduciary responsibilities. One model that might be considered is that which is used in the United Kingdom where public monies are invested alongside independent private sector funds, with investment decisions and mentoring provided by the private-sector fund managers. Essentially, the government complements private sector investment on a formula basis. In the event of a successful

\footnotetext{
${ }^{287}$ Recall that LSVCC funds in Ontario are rent-a-union LSVCCs, of which none of the studies on LSVCC funds reviewed in this dissertation, including Hebb and Mackenzie (2001), has recognized positive impacts on Canadian venture capital market.
} 
exit, the return to the public sector funding is capped, allowing the private sector funding to be levered. This approach takes advantage of private sector knowledge and track records while supplementing the overall pool of venture capital.

Regional discrepancies in venture capital activities observed in this study might also be a concern for policy makers. Venture capital funds in the Prairie and Atlantic provinces are significantly less likely to syndicate investments. ${ }^{288}$ This appears to reflect the smaller number of venture capital funds - large funds, in particular - in those provinces. Arguably, finding a syndicate partner is relatively difficult for venture capital funds in the Prairie and Atlantic provinces. Inaccessibility to a relevant syndicate partner is a serious problem, given the two significant relationships observed in this study: that the number of investors and the presence of one (or more) large investor is significantly positively related with the total amount of venture capital infused in the entrepreneurial firm as well as the likelihood of a successful exit. While this is an issue that needs to be addressed for the benefit of the entire Canadian venture capital sector, it appears to be particularly important for the Prairie and Atlantic provinces. ${ }^{289}$

Finally, the reliance on foreign sources of capital is likely to continue and may also be an issue of concern for policy makers. The Canadian venture capital sector needs foreign sources of capital (at least under the current situation) while minimizing foreign

\footnotetext{
${ }^{288}$ This is in contrast to those in Quebec.

289 At this point, it might be necessary to give an example of a statutory covenant typically faced by LSVCC funds. One such example is the requirement to invest in entrepreneurial firms in the same jurisdiction (see II-1-2-5 and Vaillancourt, 1997), leading to the ongoing debate on the issue of provincial/regional economic growth versus Canada's welfare as a whole.
} 
investors' undervaluation of Canadian entrepreneurial firms. One possible way to attain this may be to increase competition among foreign funds for Canadian investment opportunities. This is underway, in part, through the removal of tax-related impediments to foreign investment. An additional approach entails the facilitation of networks among venture capitalists in Canada and those in other countries. Sorenson and Stuart (2001) find that geographic boundaries have less of a negative effect for highly networked venture capitalists (see II-2-3-2). To the extent that some of the foreign funds become repeat players within the Canadian venture capital community, they are arguably less likely to undervalue Canadian entrepreneurial businesses. For this, Canada must maintain its solid entrepreneurial basis so that foreign investors keep finding good investment opportunities in this country. ${ }^{290}$ This might be supplemented usefully by mechanisms that minimize costs associated with distant investments, for example, by full disclosure of investment opportunities, progress of the investee firms and investment outcomes, as well as by a detailed guide to the market, all of which would reduce outsiders' reluctance to invest in Canada.

Overall, the empirical observations obtained in this study suggest the need to restructure the Canadian venture capital industry. Admittedly, there does seem to be some progress towards restructuring the sector, such as the Ontario government's recent decision

\footnotetext{
${ }^{290}$ In this regard, one of the concerns for policy makers in the Prairies and the Atlantic provinces is that, during the 2001-2009 period, no foreign fund entered venture capital deals in those provinces at later financing rounds. It may be necessary to investigate the reason behind this - whether it is due to the lack of connections between venture capitalists in those provinces and foreign investors, or the lack of deals attractive to foreign funds. A lack of connections (between venture capitalists in the Prairies and the Atlantic provinces and those in other provinces), as well as a lack of attractive deals, could also be reasons for those provinces' low level of syndication activity.
} 
regarding LSVCCs and the BDC's current legislative review of these issues. Nevertheless, several remaining issues and questions need to be addressed if restructuring is considered.

The next section discusses the limitations of this study and considers areas for future research that might yield yet a better understanding of the Canadian venture capital sector and of possible means to improve the effectiveness of the venture capital market. 


\section{Limitations of This Study and Areas for Future Research}

The venture capital industry is a particularly difficult area of finance to study, largely due to the lack of publicly available information since the firms financed by venture capitalists are privately held. Research in this area does not have the advantage of being able to access public reports such as those required to be produced by publicly traded corporations. In addition, the regulatory scrutiny of the industry is modest compared to that of other financial services, again leading to relatively little available information arising from regulatory activities. Finally, because there is no organized exchange for venture capital investments, no information derives from that type of source either. Not surprisingly then, this study, like most research on venture capital, encountered a number of limitations. In particular, some of the predictions of the bottleneck hypothesis were not able to be tested due to the data limitations. Thus, the exploration of alternative explanations was required, leading to ample suggestions for areas for future research.

However, the topics for future research did not arise solely from the limitations to this study. They also derived from the need to examine numerous questions in order to gain a deeper understanding of the nature of the bottlenecked industry as well as the need to address the various issues discussed in the previous section concerning whether and how the Canadian venture capital industry should be redesigned. This Ph.D. dissertation therefore concludes with directions for future research in an effort to discover the requirements for stimulating a flourishing venture capital sector in Canada. 


\section{3-1. Limitations of This Study}

Three major limitations of this study are discussed in this subsection: the lack of comparison of returns between early and later stage investors (3-1-1), the presence of alternative explanations (3-1-2), and the outcome (as opposed to process) focus (3-1-3). The last one is not exactly a limitation; nevertheless, there are issues that remain inconclusive due to the nature of this study (being outcome focus). ${ }^{291}$

\section{3-1-1 Comparison of Returns between Early and Later Stage Investors}

First of all, data limitations prevented the computation of deal-level rates of return earned by venture capital investors: the Thomson Financial VCReporter database does not include details on the fraction of equity acquired by the venture capitalists for any given round nor on the securities the investors hold. Due to this lack of round-specific financing information, this study was unable to compare returns between early stage investors with later stage counterparts. Doing so would have enabled an empirical test of one of the predictions of the bottleneck hypothesis, namely returns are lower for early stage investors than for later stage funds, and would have provided valuable insights as to the extent to which early stage investors are disadvantaged at the negotiation table when they are small and thus financially constrained.

\footnotetext{
291 There would also have been issues that remain inconclusive if this study had been a process focus.
} 


\section{3-1-2. Alternative Interpretations}

Venture Capitalists' Level of Experience

This dissertation investigates the impacts of small venture capitalists' limited financial capabilities on their syndication and exit behaviours, and thus involves statistical tests on the relationships between fund sizes and those activities. However, previous studies argue that fund size also contains information about the level of experience of the general partners who manage the funds (Lerner, 1994a; 1994b; Kaplan and Schoar, 2005). This study confirmed this relationship because a significant positive correlation was detected between the size of the fund and the measures of experience (see Appendix IV).

To control for the "experience" effect the fund size variable contains, this study included four alternative measures of the level of experience of the general managers of the fund (the age of the venture capital firm, the number of funds previously raised, the number of successful exits experienced, and the number of entrepreneurial firm invested, see Appendix I and II). Nevertheless, the possibility still remains that the relationship between fund size and syndication/exit practices is confounded because there may yet remain imperfections in the various measures for experience resulting in the impacts of venture capitalists' experience not being thoroughly controlled for. ${ }^{292}$

\footnotetext{
${ }^{292}$ Sorenson (2007) considers the reliability of variables frequently used as a proxy for venture capitalists' experience. He argues that: (1) age fails to distinguish between active and inactive investors, and active investors are more likely to have greater abilities; (2) the number of firms in which the venture capital firm has invested and the amount of capital the venture capital firm has invested fail to distinguish early- and later-stage investments. The experience of investors who are involved in firms at an early stage and help
} 
This suggests the possible presence of alternative interpretations. That is: the relationship between fund size and syndication behaviour, detected in this study, may reflect not only small funds' need for additional financial resources but also less experienced (and presumably small) funds' needs to: (1) acquire superior expertise and network ties of other, more experienced venture capital firms, thereby improving the quality of selection, management, and monitoring of investments (Bruining, Verwaal, Lockett, Wright, and Manigart, 2006); ${ }^{293}$ (2) enhance their reputation by showing that they are connected with prestigious venture capitalists (Seppä and Jääskeläinen, 2002); or, (3) establish a more central network position by giving and reciprocating good investment opportunities with other venture capitalists. ${ }^{294}$

them develop and mature is probably more relevant for influencing firms than those who mainly invest in later stage, already matured, firms (although later stage investors are more likely to have a greater amount invested than their early stage counterparts). Gompers (1996), while using the age of the lead venture capital firm at IPO serves as a proxy for reputation, also admits that it is an imperfect measure as experienced partners sometimes leave to start new venture capital firms.

Quantification of the level of experience of the general managers of the fund is particularly difficult for Canadian venture capital funds. In general, large (non-private independent) funds are old and have a greater number of entrepreneurial firms invested (because they generally hold a large number of portfolio companies, see V-1-1), but the quality of their value-adding services to their investee companies may be questionable as the fund managers' ability to add non-financial value is spread thinly. Large funds are more likely to enter the deal at later financing rounds (see V-1-4), so even if the entrepreneurial firm attains a successful exit, how much non-financial input was made by those large funds is uncertain (entrepreneurial firms at their early stage have greater need of venture capitalists' assistance and monitoring (Lockett and Wright, 1999, 2001; Hopp and Rieder, 2006)). Moreover, a non-private independent fund is likely to be raised regardless of the previous fund's performance. Thus, the four measures for experience used in this study (and in existing studies) may not gauge correctly the quality of the value-adding services made by large, non-private independent funds.

${ }^{293}$ Experienced venture capitalists are more likely to have a more developed network position (Sorenson and Stuart, 2001). This suggests that through syndication young venture capitalists can acquire some part of experienced venture capitalists' ties and connections.

${ }^{294}$ Controlling for the investee firms' quality would have allowed a more thorough investigation on the relationship among venture capital fund size, its experience (the degree of necessity to acquire other venture capitalists' expertise), and its syndication behavior. 
The first non-financial-based rationale for syndication (syndication for the sake of acquiring other venture capitalists' expertise) fails to explain an empirical observation that small funds are more likely to add a new (large or foreign, in particular) investor to their syndicates in later financing rounds. Given that early stage investments have greater need of assistance and monitoring, and thus require a more profound expertise to venture capitalists (Lockett and Wright, 1999, 2001; Hopp and Rieder, 2006), a higher level of syndication activities should have been observed if acquiring other venture capitalists' expertise had been the major reason.

The second and third non-financial-based rationales for syndication (syndication for enhancing reputation and that for establishing network) are consistent with the abovementioned observation. If early investors use syndication in order to enhance their reputation or establish their network position, they are more likely to invite those who have already established status and network connections, that is, large funds, to the deals that are already confirmed as "good", that is, later investment rounds. However, those rationales cannot explain other observations obtained in this study. These are: (1) the number of investors increases as investee firms grow in Canada; (2) the number of syndicate members is significantly larger for Canadian deals than American deals; (3) the impact of a dollar increase in investment size on the number of investors in the syndicate is significantly greater for Canadian deals than that for American deals; (4) in Canada, exited entrepreneurial firms have received larger amounts of venture capital when they 
are backed by a larger number of investors in a syndicate. ${ }^{295}$ Those observations are more consistent with the bottleneck hypothesis. In a nutshell, there may be alternative explanations to any one set of results but the combination of all the results is best explained by the bottleneck hypothesis.

\section{Lack of Information on Lead Investors and Investee Firm Performance}

The data used in this study lacks two types of information, namely: the identity of the lead investor and the investee firms' performance variables. The lack of information about the lead investor in a deal suggests that the result of the analysis on first round financings has two alternative interpretations. The positive and significant coefficient of size on the probability for the deal to be syndicated could mean that smaller funds are more likely to make sole investments and larger funds tend to make syndicated investments (contrary to the bottleneck hypothesis). Alternatively, if the lead investor, who discovered the entrepreneurial firm, is small and successfully finds and adds a large fund to the deal, the deal is recorded as "syndicated"; if the lead investor is unable to find a large fund as a syndicate partner, the deal is recorded as a sole investment (consistent with the bottleneck hypothesis). A future research study, one with information about the lead investor, could confirm which interpretation is more likely.

Availability of information on investee firms' quality (that is, performance variables like sales, sales growth rates, sales per number of employees, number of patents, the presence

\footnotetext{
${ }^{295}$ Neither can the first non-financial-based rationale for syndication (syndication for acquiring other venture capitalists' expertise) explain those results.
} 
of a private placement from a corporation with a related line of business, proxies for founder's experience, etc.) could have enabled the work to yet better control for the possibility that the positive relationship between fund size and investee firms' success reflects experienced venture capitalists' better deal selection and value-added activities, making the results on the impact of capital constrain more conclusive. However, such detailed information was not available. In short, any statistical test inherits the limitations resulting from data imperfections, which necessitates the usage of proxy variables that quantify qualitative factors or requires alternative interpretations, from which this study is not free.

\section{3-1-3. Outcome Focus (as opposed to Process Focus)}

The analyses of this study focused on the investigation of what actually happened as an outcome and thus is limited in its ability to identify causality. For example, if a particular type of fund (for example, a fund in the Prairies and the Atlantic provinces) is less likely to get involved in syndicated investments, it is not clear if this result is because the funds do not perceive the need to syndicate, or because they are unwilling to syndicate, or because they are willing to syndicate but no syndicate partner is available. Although in the case of funds in the Prairies and the Atlantic provinces, the latter explanation is arguably the most likely (as the number of large funds as a potential syndicate partner is 
particularly limited for those funds), the statistical analyses employed here cannot distinguish among the potential causes.

The "outcome focus" nature also limits this study's ability to analyze the relationship between capital constrain and need of risk diversification. Those are closely related in such a way that the need of diversification reduces the amount of capital allocable to an investee company; it appears not feasible to analyze the impacts of capital constraints that are independent of the risk-sharing motive of syndication. However, a qualitative, process-focus type of analyses may allow this point to be addressed. Interviews with venture capitalists would give more insights on:

1. The extent to which small fund size limits the level of diversification, and the extent to which the diversification requirement limits the amount of capital allocable to each of the investees;

2. The extent to which the small fund size influences a fund's specialization and the extent to which early stage-focus increases the level of diversification requirement. $^{296}$

3. The extent to which early stage focus increases the need for syndication, due to a higher need for risk sharing or a higher need of acquiring expertise and information from other venture capitalists. ${ }^{297}$

\footnotetext{
${ }^{296}$ Small funds tend to make early stage investments (Riding 2006b), and early stage investments are associated with higher level of uncertainty (Lockett and Wright, 1999).
} 


\section{3-2. Directions for Future Research}

There are three major areas for future research, which may be based upon this dissertation. First, a future study could investigate in more depth the nature of the bottleneck of the Canadian venture capital sector. Such work may combine usefully quantitative and qualitative analyses while addressing the limitations of this study described above and examining predictions and hypotheses that were advanced but remain untested or inconclusive due to the unavailability of data or too few observations (e.g., Hypotheses 9 and 10). A second study could expand its scope to consider the various environments in which the venture capital sector exists: examining relationships between small fund sizes and entrepreneurial firms' post-exit performance, the relation between the (possibly) bottlenecked venture capital industry and stock market activities, informal venture capital investments, and the entire entrepreneurial and financial communities in Canada. A third study could investigate ways and means of resolving or mitigating the bottleneck: what issues should be considered and what roles the government might (or should) play. The following discusses the three potential future studies in more detail.

${ }^{297}$ Early stage deals have greater need of venture capitalists ' assistance and monitoring, which require them more informational and knowledge-based resources (Lockett and Wright, 1999, 2001; Hopp and Rieder, 2006) 


\section{3-2-1. More on Bottleneck}

The first area for future study could investigate in more depth the nature of being bottlenecked in the Canadian venture capital sector. Such work could combine quantitative and qualitative analysis while addressing the limitations of this study and examining the hypotheses advanced but untested or inconclusive due to the lack of data and/or small number of observations. Given the availability of data on:

1. the lead investor;

2. a sufficient number of IPO exit observations;

3. exit values and total amount of venture capital infusion by the time of the exit;

4. operating performance information on the investee companies; and,

5. the amount invested by each of the members of a syndicate in each financing round and the valuation of the entrepreneurial firm,

the quantitative component could carry out the following analyses:

1. Re-examination of Hypothesis 2 (small venture capital funds syndicate more often) for first financing rounds. Such an examination would test how the size of the lead investor fund, who first discovered the entrepreneurial firm to invest and had discretion as to whether the first investment in the firm was to be syndicated, 
affects the probability of a syndicated (as opposed to a sole) first round investment. $^{298}$

2. Analysis of Hypothesis 8 (acquisition exits are more likely, as compared to IPO exits, when early investors are small), Hypothesis 9 (firms backed by small venture capital funds are smaller than those backed by large funds, in terms of market capitalization or issue size at the time of their IPOs), and Hypothesis 10 (the price at which a portfolio company is acquired is lower for firms backed by small venture capital funds than those backed by large funds). Testing these hypotheses was not feasible in this study because of the small number of IPO exit observations, the small number of successful exit observations with information on exit values, and the lack of investee firm operating performance data. In addition, Hypothesis 6 (entrepreneurial firms backed by small funds receive smaller amounts of venture capital than those backed by large funds by the time of their exits) could also be re-analyzed with a larger number of observations and performance-adjusted basis, for a robustness check for the results obtained in this study. $^{299}$

3. Comparison of rates of return earned by early stage investors with those generated by later stage counterparts. This would provide insights on such questions as:

\footnotetext{
${ }^{298}$ This was infeasible in this study due to the lack of information on the lead investor of the deal.

299 Due to the small number of successful exit observations with the information on the total amount of venture capital infusion, plus the lack of investee firm performance data, the results of Hypothesis 6 in this study were inconclusive.
} 
o The extent to which the entrepreneurial firm is undervalued by an entrant when the incumbent investors are financially limited; and,

- The extent to which small funds are disadvantaged at the negotiation table.

Moreover, information on operating performance of portfolio companies would permit a comparison of exit values between Canadian entrepreneurial firms backed by American funds and those backed by domestic funds, as well as exit values between foreign (mainly American) exits and domestic exits. These data would also permit an analysis of factors contributing to the exit values as well as the extent to which the exit value is due to the American funds' deeper pockets, the more experienced American funds' better valueadded activities, or United States stock/M\&A market factors.

The qualitative portion would involve interviews with venture capitalists and entrepreneur dyads to address such research questions as:

- To what extent the small size of the venture capital fund slows down the investee's growth (due to underinvestment, the diversion of the entrepreneur's time and effort from the organic growth of the company, dilution of venture capitalist value-adding activities);

- What non-financial benefits derive from an addition of a large foreign fund into the syndicate (including the benefits of American exits); 
- To what extent managers of small venture capital funds anticipate dilution of their interests by large investors and choose immature exits; and,

- To what extent and in what circumstances small venture capital funds accept to add a large fund into their syndicate in order to make additional financings, even if such further syndication results in dilution of interests. ${ }^{300}$

Moreover, as discussed in V-2-4, the international (or interprovincial, if possible) comparison of the structures of venture capital industries would provide a deeper understanding of the impacts of an industry having a relatively large number of small funds with the scarcity of large funds on syndication practices and investment outcomes of small funds in the industry, and the industry's overall performance. Such a comparison would need to consider various aspects of venture capital communities (legal, cultural, institutional, etc.) and examine the impacts of those factors, along with the industry structure factor (the percentage of large fund, etc.), on the community's syndication activities and exit practice.

A study as described above would provide yet more depth of understanding of the nature of the venture capital industry in Canada as well as those in other countries. ${ }^{301}$

\footnotetext{
300 In addition, qualitative analyses could investigate the relationship among capital constraints, risk diversification, and early-stage focus, discussed in VI-3-1-3.

${ }^{301}$ A future study could also investigate the following research questions, for an even better understanding of the venture capital investment activities in Canada:

- Rationales behind a small fund's entry into syndicates with large funds: it was found that syndicates with one or more large funds tend to add a fund that is smaller than or equal to them, rather than not to add any new investor. Is this because financial constrain is an issue even for syndicates with large funds and thus they need to amass capital even from small funds? Or, is this
} 


\section{3-2-2. Impacts of Bottleneck on Entire Entrepreneurial Activities}

Research could expand its scope to the environment surrounding the venture capital activities. One such study could relate IPO underpricing and post IPO performance of the portfolio companies to the size of the pre-IPO investors. Given that immature IPOs are more severely underpriced, small fund sizes imply an additional cost as they force venture capital funds to undertake early IPOs. This may reduce the incentive of the founders to go public. On the other hand, if small fund sizes slow down investee firms' growth, those IPOs may exhibit stronger post IPO performance after having accessed a large well of capital.

A scrutiny of the impacts of Canadian stock markets on the venture capital market could also improve further our understanding of the nature of the Canadian venture capital

an arrangement made by large funds, which provides opportunities for small (less experienced) funds to acquire large (experienced) funds' expertise? Or, since large funds typically have a large number of investees (and thus the general managers are limited in their ability to add value to each of the investee companies), are small funds added to monitor and give advice to the investee?

- Process of development of syndicates: it was found that:

o Syndicates with one or more large funds were more likely to have more investors and those comprised of very small funds were more likely to have fewer investors.

- Syndicates with foreign funds were also more likely to have more investors.

- Small funds are more likely to enter at the second round and larger (or foreign) funds are more likely to participate at the fourth, fifth, or later round. Large and foreign funds participated disproportionately in later rounds.

These results suggest that large (and foreign) funds are added as a last resort; that is, they enter a syndicate later after the syndicate has recruited several investors in order to amass capital from many small funds. Also, because in Canada large funds' financial resources are spread so thinly, i.e., availability of capital is limited even for large funds, investors and entrepreneurs must amass capital from many large (and small) funds. Or, these results may imply that a new fund entry is more likely for better value-adding services at an earlier stage (small funds are likely to specialize themselves as an early stage investor and thus have more expertise for early stage financing rounds) and for a sufficient capital infusion at later stage financing. It would be interesting to study, in more detail, how a syndicate evolves over time and with which rationale a new fund enters a syndicate. 
sector. ${ }^{302}$ To what extent do the characteristics of the Canadian stock markets, such as small issues and lack of liquidity, affect entrepreneurs' and venture capitalists' incentive to work towards IPOs? To what extent do these factors affect exit values as well as the prospects of future financing obtained from the public market? There is a view that Canadian underwriters are less capable of credibly certifying the quality of IPOs and there are relatively fewer underwriters willing to bring firms public in Canada than in the United States (Cumming and MacIntosh, 2001a). If this is the case, how do these factors affect venture capital exit activities and how can these problems be addressed?

Foerster, Karolyi and Weiner (1999) find that accessing capital, enhancing corporate credibility, and improving corporate image are three major reasons why Canadian firms already listed on the Toronto Stock Exchange also list their stocks on American exchanges. Cumming and MacIntosh (2002) argue that the pool of investors participating in the market, as well as their appetites for risk, is limited in Canada compared to those in the American market, and that American offerings give a firm greater visibility and acceptability to potential customers. The lack of strategic partners and the small M\&A market in Canada are also issues often discussed as factors limiting venture capital exits (e.g., Cumming and MacIntosh, 2002). How should these problems be addressed? To what extent are American exits advantageous to both Canadian entrepreneurial firms and venture capitalists? How will the Canadian economy as a whole be affected when American exits by Canadian corporations are facilitated (as discussed in II-1-2-3)? Israeli

\footnotetext{
${ }^{302}$ See II-3-2-6 for existing studies on environments surrounding a venture capital market.
} 
funds were successful in stimulating their country's venture capital sector by bringing companies to the United States for the purpose of an IPO (Rock, 2001, 2002). Perhaps this is a strategy that would be advantageous to the Canadian sector as there may be fewer barriers that prohibit the Canadian sector than the Israeli example.

A future study could also examine the impacts of the structure of the Canadian venture capital industry, comprised of a large number of small funds, on the entire entrepreneurship activity in Canada, including informal venture capital investments. When the small size of venture capital funds puts them in a disadvantaged position and results in lower rates of return, returns on business angel investments are also, most likely, low. If lower returns discourage informal venture capitalists, that would be a real loss for the Canadian entrepreneurial sector because they are also the ones who identify and make valuable financial and non-financial inputs to promising new businesses.

These studies would help to understand the relationship between the structure of the venture capital industry and its context, thereby providing additional insights into the efficacy of the sector and towards a more dynamic entrepreneurial society in Canada.

\section{3-2-3. Towards an Active Canadian Venture Capital Market}

The results of this study suggest that the Canadian venture capital sector is bottlenecked. This implies the necessity of redesigning the entire industry: creating more large funds 
may be one of the means to activate the Canadian venture capital sector. However, as discussed in 2-3 of this chapter, there are several other issues to consider associated with this. These considerations may be formulated directly as research questions to be addressed in future studies. They include:

- Should the government intervene? If large funds are created via a government intervention and these created government-affiliated funds end up having a large number of portfolio companies (as currently existing ones do), this would not mitigate the bottleneck problem of the Canadian industry. What is necessary are funds with great financial availability, which enable them to invest a large sum of capital in an entrepreneurial firm. Is it possible to create such funds through government intervention? This entails consideration of (at least) the following questions:

o What factors are directly related to a large number of entrepreneurial companies in currently existing portfolios of government and governmentaffiliated funds? ${ }^{303}$ How is a government or government-affiliated fund's

\footnotetext{
${ }^{303}$ This point needs to be understood in more depth than it is now. For example, we know that the statutory covenants restrict LSVCCs to investments in small companies; is this the only factor leading a large number of companies in LSVCC portfolios? To what extent do those covenants contribute to governmentaffiliated funds having a large number of portfolio companies? We know that government and governmentaffiliated funds tend to have objectives other than profit maximization (which are likely related to the large number of portfolio companies); but which objective(s) actually increase the number of investee firms in their portfolios and how? As for non-rent-a-union LSVCC funds, the answers to those questions are provided by Hebb and Mackenzie (2001; see also II-1-2-5 and VI-2-3-1); however, further investigation that addresses those questions for funds of other types is necessary.
} 
objectives and covenants related to its portfolio structure and how do they increase the number of entrepreneurial firms in its portfolio? ${ }^{304}$

○ What are the processes through which, and criteria with which, government-affiliated funds make capital allocation decisions? $?^{305}$

- What are the benefits that the Canadian venture capital sector receives from the presence of large government-affiliated funds making a large number of small investments, spreading their financial and human capital thinly - are they greater than the benefits from the presence of large funds making a smaller number of large investments? ${ }^{306}$

Investigation of these research questions would entail the consideration of the statutory constraints under which LSVCCs and Provincial VCCs operate (such as investing in entrepreneurial firms that are within a certain size threshold, operating in certain

\footnotetext{
${ }^{304}$ A future study could also investigate which objectives and covenants are directly related to the portfolio structure of other types of non-private independent funds, such as institutional investors, and how (for example, CDP Capital Private Equity, Canada's largest venture capital fund, is an institutional investor managing $\$ 9.1$ billion CDN, and it maintains 797 companies in its portfolio (see Table VI-1)).

${ }^{305}$ Large government affiliated funds hold a large number of portfolio companies because they are sought after by small funds as an additional source of capital for later financing rounds - as if they entered a deal as required. Nevertheless, we assume the presence of criteria with which government affiliated funds make decision as to which deals to invest.

Again, as for non-rent-a-union LSVCC funds, the answer is provided by Hebb and Mackenzie (2001; see also II-1-2-5 and VI-2-3-1); however, further investigation that addresses those questions for funds of other types is necessary.

${ }^{306}$ The funds' human capital also spread thinly as the general managers' ability to add value to each of the investee companies becomes limited when the fund has a large number of portfolio companies. A future research could consider the consequences of large funds' having a large number of portfolio companies, and whether it is good news for the Canadian industry.

Again, this question may not be appropriate for non-rent-a-union LSVCC funds, of which mandates are significantly different from venture capital funds in general (Hebb and Mackenzie, 2001; see also II-1-2-5 and VI-2-3-1).
} 
industries, residing in the same jurisdiction as the fund operates, within a certain deadline, see II-1-2-5). It would be necessary to examine to which extent these covenants work towards the objectives for which the provincial government has established the LSVCC or Provincial VCC scheme (e.g., strengthen the entrepreneurial sector), and whether these restrictions work towards an active venture capital market for the region and/or for the overall Canada. ${ }^{307}$

- Is there a means by which the government can intervene in the market and which would result in the creation of non-government-affiliated funds with large financial capacities?

At this point, it will be interesting to see the impact on Ontario`s venture capital activity of the province's recent legislative changes and its pending changes, which are expected to reduce LSVCC fund activities. As discussed earlier (in 2-2 of this chapter), this might revive private independent limited partnerships. ${ }^{308}$ If so, one of the means the government could use to activate the venture capital sector in Canada would to return the sector to a naturally competitive form (eliminate the interventions it made).

- What can be done in order to promote large foreign funds' participation in Canadian venture capital investments while avoiding any negative consequences of their involvement?

\footnotetext{
${ }^{307}$ Again, this argument may not be appropriate for non-rent-a-union LSVCC funds.

${ }^{308}$ Recall that LSVCC funds in Ontario are rent-a-union LSVCCs, of which none of the studies on LSVCC funds reviewed in this dissertation, including Hebb and Mackenzie (2001), has recognized positive impacts on Canadian venture capital market.
} 
In addition, there are several other issues associated with Canadian venture capital activity, such as lower levels of institutional investors' involvement, the lack of experience and industry knowledge of fund managers, and the lack of management skills of entrepreneurs (see II-1-2 and II-1-3). These issues should be addressed simultaneously with the bottleneck problem: as previously discussed (2-3 of this chapter), merely creating funds of large financial availability without a simultaneous approach to the other problems may not work or may even prove to be counterproductive.

In sum, there is considerable room for research based on this dissertation. Future studies as described above, based on the results obtained in this dissertation, will provide deeper, more informative and conclusive insights into the impacts of industry structure and small fund sizes on the practice of venture capital markets and the entire entrepreneurial community in Canada as well as in other countries. There are also ample issues to address when considering a resolution of the bottleneck and a restructuring of the Canadian venture capital industry. This dissertation together with the future studies arising from it seek to provide useful guidance for industry redesign and for a more effective venture capital sector and entrepreneurial community in Canada. 


\section{REFERENCES}

Admati, A. R. and P. Pfleiderer, (1994). Robust Financial Contracting and the Role of Venture Capitalists, Journal of Finance, 49(2), pp.371-402.

Aghion, P., P. Bolton, and J. Tirole (2004). Exit Options in Corporate Finance: Liquidity versus Incentives, Review of Finance, 8, pp.327-353.

Agresti, Alan (1996). An Introduction to Categorical Data Analysis, John Wiley \& Sons, NY.

Allison, P.D., (1995). Survival Analysis Using the SAS System: A Practical Guide, SAS Institute Inc., Cary, NC, USA.

Amit, R., J. Brander, and C. Zott (1998). Why Do Venture Capital Firms Exist? Theory and Canadian Evidence, Journal of Business Venturing, 13, 441-466.

Amit, R., L. Glosten, and E. Muller (1990). Entrepreneurial Ability, Venture Investments, and Risk Sharing, Management Science, 36(10), October, pp.1232-1245.

Barney, J.B., Busenitz, L.W., Fiet, J. O., and Moesel, D. D. (1996). New Venture Teams' Assessment of Learning Assistance from Venture Capital Firms, Journal of Business Venturing, 11, pp.257-272.

Barry, C. (1994). New Directions in Research on Venture Capital Finance, Financial Management, 23(3 Autumn), pp3-15.

Barry, C. B., C. J. Muscarella, J. W. Peavy III and M. R. Vetsuypens (1990). The Role of Venture Capital in the Creation of Public Companies, Journal of Financial Economics, $27,447-471$.

Bascha, A. and U. Walz, (2001). Convertible Securities and Optimal Exit Decisions in Venture Capital Finance, Journal of Corporate Finance, 7, pp.285-306.

Bergemann, D. and U. Hege (1998). Venture Capital Financing, Moral Hazard, and Learning, Journal of Banking \& Finance, 22, pp.703-735.

Berglof, E. (1994). A Control Theory of Venture Capital Finance, Journal of Law, Economics \& Organization, 10(2), pp.247-267. 
Bernhardt, I. (1994). Competitive Advantage in Self-employment and Paid Work, Canadian Journal of Economics, 27, pp.273-289.

Bernile, G., D. Cumming, E. Lyandres, (2007). The Size of Venture Capital and Private Equity Fund Portfolios, Journal of Corporate Finance, 13, pp.564-590

Binks, M. and C. Ennew (1996). Growing Firms and the Credit Constraint, Small Business Economics, 8(1), pp.17-25

Black, B. S. and R. J. Gilson (1998). Venture Capital and Structure of Capital Markets: Bank versus Stock Markets, Journal of Financial Economics, 47, pp.243-277.

Black, J., D. de Meza, and D. Jeffreys (1996). House Prices, the Supply of Collateral and the Enterprise Economy, Economic Journal, 106, pp.60-75.

Blanchflower, D.G. and A. J. Oswald (1998). What Makes an Entrepreneur? Journal of Labor Economics, 16(1), pp.26-60.

Bosma, N., Z. J. Acs, E. Autio, A. Coduras, and J. Levie (2009). Global Entrepreneurship $\quad$ Monitor 2008 Executive http://www3.babson.edu/ESHIP/research-publications/gem.cfm.

Bradley, D. J. and B. D. Jordan (2002). Partial Adjustment to Public Information and IPO Underpricing, Journal of Financial and Quantitative Analysis, 37(4), pp.595-616.

Brander, J. A., E. J. Egan, and T. F. Hellmann (2008). Government Sponsored versus Private Venture Capital: Canadian Evidence, National Bureau of Economic Research Working Paper Series, 14029.

Brander, J. A., R. Amit and W Antweiler (2002). Venture-Capital Syndication: Improved Venture Selection vs. the Value-Added Hypothesis, Journal of Economics \& Management Strategy, 11(3), Fall, pp.423-452.

Bratton, W. W. (2002). Venture Capital on the Downside: Preferred Stock and Corporate Control, Michigan Law Review, 100(5), March, pp.891-945.

Brierley, Peter (2001), The financing of technology-based small firms: A review of the literature, Bank of England. Quarterly Bulletin; Spring: 41-76.

Bruining, H., E. Verwaal, A. Lockett, M. Wright and S. Manigart (2006). Firm Size Effects on Venture Capital Syndication: the Role of Resources and Transaction Costs, Working paper, The Social Science Research Network Electronic Paper Collection. 
Bruno, A. and T. Tyebjee (1985). The Entrepreneur's Search for Capital, Journal of Business Venturing, 1, pp.61-74.

Bygrave, W. D. (1987). Syndicated Investments by Venture Capital Firms: A Networking Perspective, Journal of Business Venturing, 2, pp.139-154.

Bygrave, W. D. (1988). The Structure of the Investment Networks of Venture Capital Firms, Journal of Business Venturing, 3, pp.137-157.

Bygrave, W. D. and M. Quill (2007). Global Entrepreneurship Monitor 2006 Financing Report, http://www3.babson.edu/ESHIP/research-publications/gem.cfm.

Cabral, L. and J. Mata (2003). On the Evolution of the Firm Size Distribution: Facts and Theory, American Economic Review, 93, 1075-1090.

Calomiris, C. W., A. G. De Carvalho, J. Amaro de Matos (2005). Venture Capital as Human Resource Management, NBER Working Paper No. W11350.

Canadian Federation of Independent Business, Canadian Manufacturers \& Exporters, RBC Financial Group (2002). The Path to Prosperity: Canada's Small-and MediumSized Enterprises, Toronto.

Canadian Newswire Services (2008), http://www.newswire.ca/en/releases/archive/January2008/24/c3962.html, TORONTO, Jan. 24 /CNW Telbec/, accessed April 5, 2009.

Canadian Venture Capital Association (2009), http://www.cvca.ca/statistical_review/index.html, accessed September 20, 2010: .

Carpenter, R. E., S. M. Fazarri, and B. C. Petersen (1994). Inventory Investment, Internal-Finance Fluctuations, and the Business Cycle, Brookings Papers on Economic Activity, 2, pp.75-122.

Carpenter, R. E. and B.C. Petersen (2002), The Growth of Small Firms Constrained by Internal Finance? Review of Economics \& Statistics, 84(2), pp.298-309.

Carter, R. B. and H. E. Van Auken (1994). Venture Capital Firms' Preferences for Projects in Particular Stages of Development, Journal of Small Business Management, January, pp.60-73.

Casamatta, C. (2003). Financing and Advising: Optimal Financial Contracts with Venture Capitalists, Journal of Finance, 58(5), pp.2059-2086. 
Casamatta, C. and C. Haritchabalet (2003). Learning and Syndication in Venture Capital Investments, Centre for Economic Policy Research Discussion Paper No. 3867

Cestone, G. (2002). Venture Capital Meets Contract Theory: Risky Claims or Formal Control? Centre for Economic Policy Research (CEPR) Discussion Paper No. 3462.

Chan, Y., D. Siegel, and A. V. Thakor (1990). Learning, Corporate Control and Performance Requirements in Venture Capital Contracts, International Economic Journal, 31(2), pp.365-381.

Chemla, G., M. A. Habib, and A. Ljungqvist (2004). An Analysis of Shareholder Agreements, Working paper, The Social Science Research Network Electronic Paper Collection.

Chemmanur, T. and P. Fulghieri (1995). Information Production, Private Equity Financing, and the Going Public Decision, Working paper, Columbia University.

Chemmanur, T., S. He and D. Nandy (2007). The Going Public Decision and the Product Market, Working paper, The Social Science Research Network Electronic Paper Collection.

Cochrane, J. H. (2005). The Risk and Return of Venture Capital, Journal of Financial Economics, 75(1), January, pp.3-52.

Cooley, T. F. and V Quasrini (2001). Financial Markets and Firm Dynamics, American Economics Review, 91, 1286-1311.

Cornelli, F. and O. Yosha (2003). Stage Financing and the Role of Convertible Securities, Review of Economic Studies, 70, pp.1-32.

Cumming, D. J. (2002). Contracts and Exits in Venture Capital Finance, Working paper, The Social Science Research Network Electronic Paper Collection.

Cumming, D. J. (2005a). Agency Costs, Institutions, Learning, and Taxation in Venture Capital Contracting, Journal of Business Venturing, 20, pp.573-622.

Cumming, D. J. (2005b). Capital Structure in Venture Finance, Journal of Corporate Finance, 11, pp.550-585.

Cumming, D. J. (2005c). Adverse Selection and Capital Structure: Evidence from Venture Capital, Working paper, The Social Science Research Network Electronic Paper Collection. 
Cumming, D. J. (2006). The Determinants of Venture Capital Portfolio Size: Empirical Evidence, Journal of Business, 79(3), pp.1083-1126.

Cumming, D. J. (2007a). Government Policy towards Entrepreneurial Finance: Innovation Investment Funds, Journal of Business Venturing, 22, pp.193- 235.

Cumming, D. J. (2007b). United States Venture Capital Financial Contracting: Foreign Securities, Advances in Financial Economics, 12, pp.405-444.

Cumming D.J., G. Fleming, and A. Schwienbacher (2005). Liquidity Risk and Venture Capital Finance, Financial Management, Winter, pp.77-105.

Cumming D.J., G. Fleming, and A. Schwienbacher (2006). Legality and Venture Capital Exits, Journal of Corporate Finance, 12, pp.214-245.

Cumming, D. J. and S. A. Johan (2006). Provincial Preferences in Private Equity, Financial Markets Portfolio Management, 20(4) pp. 369 - 398.

Cumming D.J. and J.G. MacIntosh (2001a). The Extent of Venture Capital Exits: Evidence from Canada and the United States, Working Paper, The Social Science Research Network Electronic Paper Collection.

Cumming D.J. and J.G. MacIntosh (2001b). Venture Capital Investment Duration in Canada and the United States, Journal of Multinational Financial Management, 11, pp.445-463.

Cumming D.J. and J.G. MacIntosh (2002). Venture Capital Exits in Canada and the United States, University of Toronto Law Journal, 55, pp.101-200.

Cumming D.J. and J.G. MacIntosh (2003). A Cross-Country Comparison of Full and Partial Venture Capital Exits, Journal of Banking and Finance, 27, 511-548.

Cumming D.J. and J.G. MacIntosh (2006). Crowding out Private Equity: Canadian Evidence, Journal of Business Venturing, 21 pp.569-609.

Cumming D.J., D. Schmidt, U. Walz (2006). Legality and Venture Governance around the World, Working Paper, The Social Science Research Network Electronic Paper Collection.

Das, S. R., M. Jagannathan, and A. Sarin (2003). Private Equity Returns: An Empirical Examination of The Exit of Venture Backed Companies. Journal Of Investment Management, 1(1), First Quarter, pp.1-26. 
De Clercq, D. and D. P. Dimov (2004). Explaining Venture Capital Firms' Syndication Behaviour: a Longitudinal Study, Venture Capital, 6(4), pp.243-256.

Desal, M., P. Gompers and J. Lerner (2006). Institutional, Capital Constraints and Entrepreneurial Firm Dynamics: Evidence from Europe, Working Paper, The Social Science Research Network Electronic Paper Collection.

Dimov, D. and Murray, G. C. (2006). Through a Glass Darkly: New Perspectives on the Equity Gap, in Schamp, T. (ed.), Entrepreneurship and the Financial Community: Starting Up and Growing New Business. Edward Elgar, London.

Duruflé G. (2006). The Drivers of Canadian VC Performance, Full Report, http://www.cvca.ca/files/Full Report5.pdf

Duruflé G. (2007). The Drivers of Canadian Private Equity Performance, VC 2007: an industry in transition, Buy out: A performing asset class presented at the CVCA Annual Conference, May 29, http://www.cvca.ca/files/Resources/Durufl.Halifax.Long.pdf

Elango, B., V. H. Fried, R. D. Hisrich, and A. Polonchek (1995). How Venture Capital Firms Differ, Journal of Business Venturing, 10, pp.157-179.

Evans, D. S. and B. Javanovic (1989). An Estimated Model of Entrepreneurial Choice under Liquidity Constraints, Journal of Political Economy, 97, pp.808-827.

Falconer, K. (1999). Prudent, Patience and Jobs: Pension Investment in a Changing Canadian Economy Technical Report, Canadian Labour Market and Productivity Centre (CLMPC).

Faure-Grimaud, A. and D. Gromb (2004). Public Trading and Private Incentives, Review of Financial Studies, 17(4), pp.985-1014.

Fazzari, S. M., G. Hubbard, and B. Petersen (1988). Financing Constraints and Corporate Investment, Brookings Papers on Economic Activity, 1, pp.141-206.

Ferrary, M. (2003). The Gift Exchange in the Social Networks of Silicon Valley, California Management Review, 45(4), pp.120-138.

Florida R. and M. Kenney (1988). Venture Capital and High Technology Entrepreneurship, Journal of Business Venturing, 3, pp.301-319

Fluck, Z., K. Garrison, and S. C. Myers (2005). Venture Capital Contracting and Syndication: an Experiment in Computational Corporate Finance, National Bureau of Economic Research Working Paper Series, 11624. 
Foerster, S., Karolyi, A., and Weiner, D. (1999). Capital Rewards: The Lure of U.S. Exchanges, Ivey Business Journal, 63(4), May/June, pp.62-66.

Fried. V. H. and R. D. Hisrich.(1995). The Venture Capitalist: A Relationship Investor, California Management Review, 37, pp.101-113.

Fulghieri, P. and M. Sevilir, (2005). Size and Focus of a Venture Capitalist's Portfolio, Working paper, The Social Science Research Network Electronic Paper Collection.

Gilson, R. J. (2003). Engineering Venture-Capital Market: Lessons from the American Experience, Stanford Law Review, 55, pp.1067-1103.

Gilson, R. J. and D. M. Schizer (2003). Understanding Venture-Capital Structure: A Tax Explanation for Convertible Preferred Stock, Harvard Law Review, 116(3), pp.874-916.

Giot, P. and A. Schwienbacher (2006). IPOs, Trade Sales and Liquidations: Modelling Venture Capital Exits using Survival Analysis, Working paper, University of Namur.

Glaeser, E., S. Johnson, and A. Shleifer (2001). Coase Versus the Coasians, Quarterly Journal of Economics. August, pp.853-899.

Gomez-Mejia, L. R., D. B. Balkin, Welbourne, T. M. (1990). Influence of Venture Capitalists on High Tech Management, Journal of High Technology Management Research, 1(1), pp.103-118.

Gompers, P. A. (1995). Optimal Investment, Monitoring, and the Staging of Venture Capital, Journal of Finance, 50 (December), pp.1461-1490.

Gompers, P. A. (1996). Grandstanding in the Venture Capital Industry, Journal of Financial Economics, 42 (September), pp.133-156.

Gompers, P.A., (1998). Venture Capital Growing Pains: Should the Market Diet? Journal of Banking \& Finance, 22, 1089-1104.

Gompers, P. A., A. Kovner, J. Lerner, and D. Scharfstein (2005). Venture Capital Investment Cycles: The Impact of Public Markets, National Bureau of Economic Research Working Paper Series, 11385.

Gompers, P. A., A. Kovner, J. Lerner, and D. Scharfstein (2006). Skill vs. Luck in Entrepreneurship and Venture Capital: Evidence from Serial Entrepreneurs, National Bureau of Economic Research Working Paper Series, 12592. 
Gompers, P. A. and J. Lerner (1996). The Use of Covenants: An Empirical Analysis of Venture Partnership Agreements, Journal of Law and Economics, 39(2), October, pp. 463-498.

Gompers, P., and J. Lerner (1997). Money Chasing Deals? The Impact of Fund Inflows on Private Equity Valuations. Working paper, Harvard University, Cambridge, MA.

Gompers, P. A. and J. Lerner (1999a). What Drives Venture Capital Fundraising? National Bureau of Economic Research Working Paper Series, 6906.

Gompers, P. A. and J. Lerner (1999b). The Venture Capital Cycle, MIT Press, Cambridge, Mass.

Gompers, P. A. and J. Lerner (1999c). An Analysis of Compensation in the U.S. Venture Capital Partnership, Journal of Financial Economics, 51(3) pp.3-44.

Gompers, P. A. and J. Lerner (2000). Money Chasing Deals? The Impact of Fund Inflows on Private Equity Valuations, Journal of Financial Economics, 55 pp.281-325.

Gompers, P. A. and J. Lerner (2001). The Venture Capital Revolution, Journal of Economic Perspectives 15, pp.145-168.

Gompers, P. A., Y. Xuan (2006). The Role of Venture Capitalists in the Acquisition of Private Companies, Working paper, The Social Science Research Network Electronic Paper Collection.

Gorman, M. and W.A. Sahlman (1989). What Do Venture Capitalists Do? Journal of Business Venturing, 4, pp.231-248.

Guiso, L. (1998). High Tech Firms and Credit Rationing, Journal of Economic Behavior and Organization, 35, pp.39-59.

Guler, I. and M. F. Guillén (2006a). Institutions, Networks, and Organizational Growth: A Weberian Perspective, Working paper, The Social Science Research Network Electronic Paper Collection.

Guler, I. and M. F. Guillén (2006b). Social Networks, Uncertainty, and Market Choice, Working paper, The Social Science Research Network Electronic Paper Collection.

Gupta, A. K. and H. J. Sapienza (1992). Determinants of Venture Capital Firms' Preferences regarding the Industry Diversity and Geographic Scope of Their Investments, Journal of Business Venturing, 7, pp.347-362 
Hebb, T. and D. Mackenzie (2001). Canadian Lebour-Sponsored Investment Funds: A Model for U.S. Economically Targeted Investments, in Fung, A. T. Hebb. And J. Rogers (ed.), Working Capital: The Power of Labor's Pensions. Cornell University Press, New York.

Heckman, J. J. (1979). Sample Selection Bias as a Specification Error, Econometrica, 47(1), pp.153-161.

Hellman, T. and M. Puri (2002). Venture Capital and the Professionalization of Start-Up Firms: Empirical Evidence, Journal Of Finance, 57(1), February, pp.169-197.

Hellmann, T. (1998). The Allocation of Control Rights in Venture Capital Contracts, Rand Journal of Economics, 29(1), pp.57-76.

Hellmann, T. (2002). IPOs, Acquisitions and the Use of Convertible Securities in Venture Capital, Working paper, The Social Science Research Network Electronic Paper Collection.

Helwege, J. and F. Packer (2004) Private Matters, Working paper, The Social Science Research Network Electronic Paper Collection.

Helwege, J. and N. Liang (2004). Initial Public Offerings in Hot and Cold Markets, Journal of Financial and Quantitative Analysis, 39(3), 541-569.

Hibbard, J. (2004). Fresh Seed in the Valley, Business Week, July 19.

Hochberg, Y. V. (2003). Venture Capital and Corporate Governance in the Newly Public Firm, Working paper, The Social Science Research Network Electronic Paper Collection.

Hochberg, Y. V., A. Ljungqvist, and Y. Lu (2007). Whom You Know Matters: Venture Capital Networks and Investment Performance, Journal of Finance, 62(1), pp251-301.

Hopp, C. (2006). Chance Favours the Prepared Mind: The Determinants of Monitoring and Staging in Venture Capital Financing, Working paper, The Social Science Research Network Electronic Paper Collection.

Hopp, C. and F. Rieder (2006). What drives Venture Capital Syndication? Working paper, The Social Science Research Network Electronic Paper Collection.

Hoshi, T., A. Kashyap, and D. Scharfstein (1991). Corporate Structure, Liquidity, and Investment: Evidence from Japanese Industrial Groups, Quarterly Journal of Economics, 106, pp.33-60. 
Houben, E. (2002). Venture Capital, Double-sided Adverse Selection and Double-sided Moral Hazard, Working paper, The Social Science Research Network Electronic Paper Collection.

Hsu, D. H. (2004). What Do Entrepreneurs Pay for Venture Capital Affiliation? Journal of Finance, 59(4), pp1805-1844.

Huntsman, B. and J. P. Hoban Jr. (1980). Investment in New Enterprise: Some Empirical Observations on Risk, Return, and Market Structure, Financial Management, 9(2), Summer, pp.44-51.

Ibbotson, R. G.; and J. F. Jaffe (1975). "Hot Issue" Market, Journal of Finance, 30(4) pp.1027-1042.

Industry Canada (2004). Canadian Venture Capital Activity: An Analysis of Trends and Gaps 1996-2002, http:// www.strategis.gc.ca/fdi.

Jääskeläinen, M., M. Maula and T. Seppä (2006). Allocation of Attention to Portfolio Companies and the Performance of Venture Capital Firms, Entrepreneurship Theory and Practice, March, pp.185- 206.

Jaffee, D. M. and T. Russell (1976). Imperfect Information, Uncertainty, and Credit Rationing, Quarterly Journal of Economics, 90, pp.651-667.

Jain, B. A. and O. Kini (1994). The Post-Issue Operating Performance of IPO Firms, Journal of Finance, 49(5), 1699-1726.

Jeng, L. A. and P. C. Wells (2000). The Determinants of Venture Capital Funding: Evidence across Countries, Journal of Corporate Finance, 6, 241-289.

Jensen M. H. and W. H. Meckling (1976). Theory of the Firm, Managerial Behaviour, Agency Costs and Ownership Structure, Journal of Financial Economics, 3(4) pp.305360.

Kalay, A. and J. F. Zender (1997). Bankruptcy, Warrants, and State-Contingent Changes in the Ownership of Control, Journal of Financial Intermediation, 6, pp.347-379.

Kanniainen, V. and C. Keuschnigg (2003). The Optimal Portfolio of Start-up Firms in Venture Capital Finance, Journal of Corporate Finance, 9, pp.521- 534.

Kanniainen, V. and C. Keuschnigg (2004). Start-Up Investment with Scarce Venture Capital Support, Journal of Banking \& Finance, 28, pp.1935-1959. 
Kaplan, S. N. and P. Stromberg (2003). Financial Contracting Theory Meets the Real World: an Empirical Analysis of Venture Capital Contracts, Review of Economic Studies, 70, pp.281-315.

Kaplan, S. N. and P. Stromberg (2004). Characteristics, Contracts, and Actions: Evidence from Venture Capitalist Analyses, Journal Of Finance, 59(5) pp.2177-2210.

Kaplan, S. N. and Schoar, A. P (2005). Private Equity Performance: Returns, Persistence and Capital Flows, Journal of Finance, 60(4), pp.1791-1823.

Kaplan, S. N., F. Martel and P. Strömberg (2004). How Do Legal Differences and Learning Affect Financial Contracts? Working paper, The Social Science Research Network Electronic Paper Collection.

Knill, A. M. (2005). Should Venture Capitalists Put All Their Eggs in One Basket? Diversification versus Pure Play Strategies in Venture Capital, Financial Management, Forthcoming.

Kortum, S., and J. Lerner (2000). Assessing the Contribution of Venture Capital to Innovation, Rand Journal of Economics, 31(4), pp.674-692.

La Porta, R., F. Lopez-de-Silanes, A. Shleifer, and R. W. Vishnyr (1997). Legal Determinants of External Finance, Journal of Finance, 52(3), pp.1131-1150.

Laine, M. and S. Torstila (2003). The Exit Rates of Liquidated Venture Capital Funds, Working paper, The Social Science Research Network Electronic Paper Collection.

Lauterbach, R., I. Welpe, V. Calanog, and M. Wahrenburg (2006). Investment Pressure Effecting Behaviour? The Impact of Fund Inflows on Staging and Speed of Capital Allocation, Working paper, The Social Science Research Network Electronic Paper Collection.

Lee, P. M. and S. Wahal (2002) Grandstanding, Certification and the Underpricing of Venture Backed IPOs, Working paper, The Social Science Research Network Electronic Paper Collection.

Leleux, B. and B. Surlemont (2003). Public versus Private Venture Capital: Seeding or Crowding Out? A Pan-European Analysis, Journal of Business Venturing, 18, pp.81-104.

Lerner, J. (1994a). The Syndication of Venture Capital Investments, Financial Management, 23 (Autumn), pp.16-27.

Lerner, J. (1994b). Venture Capitalists and the Decision to Go Public, Journal of Financial Economics, 35 (June), pp.293-316. 
Lerner, J. (1995). Venture Capitalists and the Oversight of Private Firms, Journal of Finance, 50 (March), pp.301-318.

Lerner, J. (1999). The Government as a Venture Capitalist: The Long-Run Effects of the SBIR Program, Journal of Business, 72, pp.285-318.

Lerner, J. (2002). When Bureaucrats Meet Entrepreneurs: The Design of Effective 'Public Venture Capital' Programs, Economic Journal, 112 (February), pp.F73-F84.

Lerner, J. and A. Schoar (2005). Does Legal Enforcement Affect Financial Transactions? The Contractual Channel in Private Equity, The Quarterly Journal of Economics, February, pp.223-246.

Lerner, J., A. Schoar, and W. Wong (2005). Smart Institutions, Foolish Choices?: The Limited Partner Performance Puzzle, Working paper, The Social Science Research Network Electronic Paper Collection.

Lin, T. H. and R. L. Smith (1998). Insider Reputation and Selling Decisions: Unwinding of Venture Capital Investments During Equity IPOs, Journal of Corporate Finance, 4, 241-263.

Ljungqvist, A. (2008). IPO Underpricing: A Survey, Handbook In Corporate Finance: Empirical Corporate Finance, B. E. Eckbo, Ed.

Ljungqvist, A. and M. Richardson (2003). The Investment Behavior of Private Equity Fund Managers, Working paper, The Social Science Research Network Electronic Paper Collection.

Lockett, A. and M. Wright (1999). The Syndication of Private Equity: Evidence from the UK, Venture Capital, 1(4), pp.303-324.

Lockett, A. and M. Wright (2001). The Syndication of Venture Capital Investments, Omega, 29, pp.375-390.

Loughran, T. and J. R. Ritter (2002). Why Don't Issuers Get Upset about Leaving Money on the Table in IPOs? The Review of Financial Studies, 15(2) pp. 413-443.

Loughran, T., J. R. Ritter, and K. Rydqvist (1994). Initial Public Offerings: International Insights, Pacific Basin Finance Journal, 2, 165-199.

Lowry, M. (2003). Why Does IPO Volume Fluctuate So Much? Journal of Financial Economics, 63, 3-40. 
Lowry, M. and G. W. Schwert (2002). IPO Market Cycles: Bubbles or Sequential Learning?, Journal of Finance, 57(3), pp.1171-1200.

Macdonald \& Associates (2004). Finding the Key: Canadian Institutional Investors and Private Equity, www.strategis.gc.ca/fdi.

MacMillan, I. C., R. Siegel, and P. N. S. Narasimha (1985). Criteria Used by Venture Capitalists to Evaluate New Venture Proposals, Journal of Business Venturing, 1, pp.119128.

Makri, M., M. Junkunc and J. T. Eckhardt (2007). Technological Diversification, Cumulativeness and Venture Capital Exit: M\&A versus IPO, Frontiers of Entrepreneurship Research, 2007.

Manigart, S., A. Lockett, M. Meuleman, M. Wright, H. Landstrom, H. Bruining, P. Desbrieres, and U. Hommel (2004). Why do European Venture Capital Companies Syndicate? Working paper, The Social Science Research Network Electronic Paper Collection.

Manigart. S., K. De Waelea, M. Wright, K. Robbie, P. Desbrie`es, H. J. Sapienza, and A. Beekman (2002). Determinants of Required Return in Venture Capital Investments: A Five-Country Study, Journal of Business Venturing, 17, pp.291-312.

Marx, L. M. (1998). Efficient Venture Capital Financing Combining Debt and Equity, Review of Economic Design, 3, pp.371-387.

Maula, M., E. Autio, and G. Murray (2005). Corporate Venture Capitalists and Independent Venture Capitalists: What do They Know, Who do They Know and Should Entrepreneurs Care? Venture Capital, 7(1), pp. 3-21.

Mayer, C., K. Schoors, Y. Yafeh (2005). Sources of Funds and Investment Activities of Venture Capital Funds: Evidence from Germany, Israel, Japan and the United Kingdom, Journal of Corporate Finance, 11, pp.586-608.

Megginson, W. and K. A. Weiss (1991). Venture Capitalists Certification in Initial Public Offerings, Journal of Finance, 46(3), 879-903.

Michelacci, C. and J. Suarez (2004). Business Creation and the Stock Market, Review of Economic Studies, 71, pp.459-481

Moore, B. (1994). Financing Constraints to the Growth and Development of Small High Technology Firms, In Finance and the Small Firm, eds. A. Hughes and D.J. Storey, pp.112-144, London: Routledge. 
Murray, G. C. (1999). Early-Stage Venture Capital Funds, Scale Economies and Public Support, Venture Capital, 1(4), pp.351-384.

Murray, G. C. (2007). Venture Capital and Government Policy, in Landstrom, H. (ed.), Handbook of Research on Venture Capital. Edward Elgar, London, pp.113-151.

Murray, G. C. and R. Marriott (1998). Why has the Investment Performance of Technology-Specialist, European Venture Capital Funds been so Poor? Research Policy, 27(9), pp.947-976.

Myers, S. (2000). Outside Equity, Journal of Finance, 55, pp.1005-1037.

Myers, S. and N. Majluf (1984). Corporate Financing and Investment Decisions When Firms Have Information that Investors do not Have, Journal of Financial Economics, 13, pp.187-221.

Neher, D. V. (1999). Staged Financing: An Agency Perspective, Review of Economic Studies, 66, pp.255-274.

Norton, E. and B. Tenenbaum (1993). Specialization versus Diversification as a Venture Capital Investment Strategy, Journal of Business Venturing, 8, pp.431-442

Oakey, R. (1984). Finance and Innovation in British Small Independent Firms, Omega, International Journal of Management Science, 12, pp.113-24.

Oliner, S. D. and G. D. Rudebusch (1992). Sources and Financing Hierarchy for Business Investment, Review of Economics and Statistics, 74, pp.643-654.

Organization for Economic Co-operation and Development (OECD), (1996). Government Programs for Venture Capital, Paris: Organization for Economic Cooperation and Development.

Pagano, M., F. Panetta, and L. Zingales (1998). Why Do Companies Go Public? An Empirical Analysis, Journal of Finance, 53 (1) 27-64.

Parker, S. C. and C. Mirjam van Praag (2005). Schooling, Capital Constraints and Entrepreneurial Performance: The Endogenous Triangle, Tinberden Institute Discussion Paper No. TI 2004-106/3.

Pichler, P. and W. Wilhelm (2001). A Theory of the Syndicate: Form Follows Function, Journal of Finance, 56(6), pp.2237-2264.

Rajan, R. G. (1992). Insiders and Outsiders: the Choice between Informed and Arm'sLength Debt, Journal of Finance, 47(4) September, pp.1367-1400. 
Rajan, R. and H. Servaes (1997). Analyst Following of Initial Public Offerings, Journal of Finance, 52(2) pp.507-529.

Repullo, R. and J. Suarez (2004). Venture Capital Finance: A Security Design Approach, Review of Finance, 8, pp.75-108.

Riding, A, L. (2006a) Case Studies on Risk Capital, Report Commissioned by the Small Business Policy Branch, Industry Canada. Government of Canada, Ottawa.

Riding, A. (2006b) Innovation in Ontario: Financing Matters, Report Commissioned by the Ontario

Riding, A. (2008). Business Angels and Informal Investment, AGSE International Entrepreneurship Research Exchange, Melbourne, Australia.

Ritter, J. R. (1984). The "Hot Issue" Market of 1980, Journal of Business, 57(2) pp.215240.

Ritter, J. R. (1987). Costs of Going Public, Journal of Financial Economics, 19 pp.269281.

Ritter, J. R. (1991). The Long-Run Performance of Initial Public Offerings, Journal of Finance, 46(1) pp.3-27.

Ritter, J. R. and I. Welch (2002). The Review of IPO Activity, Pricing and Allocations, Journal of Finance, 57(4) pp.1795-1828.

Rock, E. B. (2001). Greenhorns, Yankees, and Cosmopolitans: Venture Capital, IPOs, Foreign Firms, and U.S. Markets, Theoretical Inquiries in Law, 2(2), pp.1034-1034.

Rock, E. B. (2002). Coming to America? Venture Capital, Corporate Identity and U.S. Securities Law, Global Markets, Domestic Institutions: Corporate Law and Governance in a New Era of Cross-Border Deals, C. J. Milhaupt, ed., New York: Columbia University Press.

Roel, A. (1996). The Decision to Go Public: An Overview, European Economic Journal, 40, pp.1071-1081.

Rosenstein, J. (1988). The Board and Strategy: Venture Capital and High Technology, Journal of Business Vennring, 3, pp.159-170.

Rydqvist, K. and K. Hogholm (1995). Going Public in the 1980s: Evidence from Sweden, European Financial Management, 1(3) pp.287-315. 
Sahlman, W. A. (1990). The Structure and Governance of Venture Capital Organizations, Journal of Financial Economics, 27, pp.473-521.

Sapienza, H. J. and M. A. Korsgaard (1996). Procedural Justice in Entrepreneur-Investor Relations, Academy of Management journal, 39(3), pp.544-574.

Sapienza, H. J., Manigart, S., and Vermeir, W. (1996). Venture Capitalist Governance and Value-Added in Four Countries, Journal of Business Venturing, 11, pp.439-470.

Schaller, H. (1993). Asymmetric Information, Liquidity Constraints, and Canadian Investment, Canadian Journal of Economics, 26, pp.552-574.

Schmidt, K. M. (2003). Convertible Securities and Venture Capital Finance, Journal of Finance, 58(3), pp.1139-1166.

Schwienbacher, A. (2005). An Empirical Analysis of Venture Capital Exit in Europe and the United States, Working paper, The Social Science Research Network Electronic Paper Collection.

Seppä, T. and M. Jääskeläinen (2002). How the Rich Become Richer in Venture Capital: Firm Performance and Position in Syndication Networks, Frontiers of Entrepreneurship Research.

Shane, S. amd D. Cable (2002). Network Ties, Reputation, and the Financing of New Ventures, Management Science, 48(3), pp.364-381.

Shiller, R. J. (1990). Speculative Prices and Popular Models, Journal of Economic Perspective, 4, pp.55-65.

Siegel, R., E. Siegel and I. C. Macmillan (1988). Corporate Venture Capitalists: Autonomy, Obstacles, and Performance, Journal of Business Venturing, 3, pp.233-247

Smith, B.G. (1997). Comment. in: Halpern, P. (ed.), Financing Innovative Enterprise in Canada. University of Calgary Press, pp. 674-677.

Smith, D. G. (2005). The Exit Structure of Venture Capital, UCLA Law Review, 53, pp.315-356.

Söderblom, A. and J. Wiklund (2005). Factors Determining the Performance of EarlyStage, High Technology Venture Capital Funds, London, Small Business Service.

Sorensen, M. (2007). How Smart is Smart Money? A Two-Sided Matching Model of Venture Capital, Journal of Finance, 62(6), pp.2725-2762. 
Sorenson, O. and T. E. Stuart (2001). Syndication Networks and the Spatial Distribution of Venture Capital Investments, American Journal of Sociology, 106(6), pp.1546-1588.

Stevens, J. (1996). Applied Multivariable Statistics for the Social Sciences, Lawrence Erlbaum Associates, MahWah, New Jersey.

Stiglitz, J. and A. Weiss (1981). Credit Rationing in Markets with Imperfect Information, American Economic Review, 71, pp.393-410.

Stuart, T. E., H. Hoang, and R. C. Hybels (1999). Interorganizational Endorsements and the Performance of Entrepreneurial Ventures, Administrative Science Quarterly, 44, pp.315-349.

Thomson Financial (2007). Canada's Venture Capital Industry in Q4 2006, http://www.cvca.ca/files/Downloads/Press Conference Q4 2006 VC Data Deck.PDF. pdf.

Thomson Financial (2008). Canada's Venture Capital Industry in 2007, http://www.cvca.ca/files/Downloads/Press Conference Q4 2007 VC Data Deck.P

Thomson Financial (2009). Canada's Venture Capital Industry in Q4 2008, http://www.cvca.ca/files/Downloads/Final_English Q4_2008 VC Data Deck.pdf.

Thomson Financial (2010). Canada's Venture Capital Industry in 2009, http://www.cvca.ca/files/Downloads/Final English Q4 2009 VC Data Deck.pdf.

Thomson Reuters (2009). Annual Statistical Review. http://www.cvca.ca/resources/statistics.

Thomson Reuters (2010). Annual Statistical Review. http://www.cvca.ca/resources/statistics.

Tykvová, T. (2005). Who Chooses Whom? Syndication, Skills and Reputation, ZEW (Centre for European Economic Research) Discussion Paper No. 05-74.

Vaillancourt, F. (1997). Labour-Sponsored Venture Capital Funds in Canada: Institutional Aspects, Tax Expenditure and Employment Creation, in: Halpern, P. (ed.), Financing Innovative Enterprise in Canada. University of Calgary Press, pp. 571- 592.

Wang, K., C. K. Wang, and Q. Lu (2002). Differences in Performance of Independent and Finance-Affiliated Venture Capital Firms, Journal of Financial Research, 25(1) Spring, pp.59-80. 
Watson, H. (1984). Credit Markets and Borrowers Effort, Southern Economic Journal, 50. pp.802-814.

Westhead, P., and D. J. Storey (1997). Financial Constraints on the Growth of Hightechnology Small Firms in the United Kingdom, Applied Financial Economics 7, pp.197-201.

Williamson, S. D. (1987a). Costly Monitoring, Loan Contracts and Equilibrium Credit Rationing, Quarterly Journal of Economics, 102, pp.135-146.

Williamson, S. D. (1987b). Financial Intermediation, Business Failures, and Real Business Cycles, Journal of Political Economy, 95, pp1196-1217.

Wright, M. and A. Lockett (2003). The Structure and Management of Alliances: Syndication in the Venture Capital Industry, Journal of Management Studies, 40(8), pp.2073-2102. 


\section{Appendix I: Control Variables for Analyses of Syndication Patterns}

This Appendix I discusses the control variables employed in the regression analyses of

syndication patterns. Table A-1 presents the list of control variables along with reference

to models in which they were used and their respective definitions.

Table A-1: List of Controlling Variables for Analyses on Syndication

\begin{tabular}{|c|c|c|}
\hline $\begin{array}{l}\text { Variable } \\
\text { Name }\end{array}$ & $\begin{array}{l}\text { Included in } \\
\text { Model(s) }\end{array}$ & Definition \\
\hline Industry & $\begin{array}{l}\text { Model } 2,3, \\
4,5\end{array}$ & $\begin{array}{l}\text { Industry sector of the investee. A categorical variable with four levels } \\
\text { (Life Sciences, IT, Other Technologies, Traditional). }{ }^{309}\end{array}$ \\
\hline \multirow[t]{4}{*}{ Type } & Model 1 & $\begin{array}{l}\text { A dummy variable equal to } 0 \text { if the fund is private independent, } 1 \text { if it is } \\
\text { not. }\end{array}$ \\
\hline & Model 2 & $\begin{array}{l}\text { Type of the fund (if sole investment), or the type of the funds that form } \\
\text { the majority of funds in the syndicate (if syndicated investment). A } \\
\text { categorical variable with five levels (private independent, corporate } \\
\text { affiliated (institutional investor, corporate financial, corporate industrial), } \\
\text { government affiliated (LSVCC, provincial VCC), government, and } \\
\text { other. }{ }^{311}\end{array}$ \\
\hline & Model 4 & $\begin{array}{l}\text { A categorical variable defined as for model } 2 \text {, except that it has six levels } \\
\text { (private independent, corporate affiliated (institutional investor, corporate } \\
\text { financial, corporate industrial), government affiliated (LSVCC, provincial } \\
\text { VCC), government, foreign, and other. }{ }^{312}\end{array}$ \\
\hline & Model 3, 5 & $\begin{array}{l}\text { A categorical variable defined as for model } 2 \text {, except that: (1) it has six } \\
\text { levels (private independent, corporate affiliated (institutional investor, } \\
\text { corporate financial, corporate industrial), government affiliated (LSVCC, } \\
\text { provincial VCC), government, foreign, and other; (2) only the incumbent } \\
\text { fund/syndicate is/are taken into account. }\end{array}$ \\
\hline Location & Model 1 & $\begin{array}{l}\text { Province in which the fund's headquarter is located. A categorical } \\
\text { variable with four levels (Ontario, British Columbia, Quebec, and }\end{array}$ \\
\hline
\end{tabular}

309 "Life Sciences" includes biopharmaceuticals, healthcare, medical devices and equipment, and medical/biotech software and information services. "IT" includes communications and networking, electronics and computer hardware, internet focus, semiconductors, software, and other IT services. "Other Technologies" includes energy and environmental technologies and other technologies. "Traditional" includes consumer and business services, consumer products, finance, manufacturing, retail, and miscellaneous. These are standard breakdowns as employed in the industry.

310 Non-private independent includes institutional investors, corporate financial, corporate industrial, LSVCCs, Provincial VCC, government. See II-1-2-3 for the definition of fund types. They are put into one category under "Non private independent" due to the small numbers of observations for each.

311 "Other" includes cases where foreign investors form the majority of funds in the syndicate and cases of tie (e.g., the deal made by two private independent and two LSVCCs).

312 "Other" includes cases of tie (e.g., the deal made by two private independent and two LSVCCs). In model 2 "Other" and "Foreign" are combined (under the name "Other"), due to the small number of observations where foreign investors form the majority of funds in the syndicate (nine). In model 3, there are 62 observations where foreign investors form the majority of funds in the incumbent syndicate, thus "Other" and "Foreign" categories are separated. 


\begin{tabular}{|c|c|c|}
\hline & Model 2 & $\begin{array}{l}\text { Prairie/Atlantic provinces). } \\
\text { Province in which the investee is located. A categorical variable with four } \\
\text { levels (Ontario, British Columbia, Quebec, Prairie/Atlantic provinces). }\end{array}$ \\
\hline & Model 3, 5 & $\begin{array}{l}\text { A categorical variable with five levels: Ontario, British Columbia, } \\
\text { Quebec, Prairie/Atlantic Provinces, and other. A deal is classified in a } \\
\text { particular category, say, Ontario, when the following two conditions are } \\
\text { met: (1) the location of the funds that form the majority of funds in the } \\
\text { incumbent syndicate is Ontario; and, (2) the location of the investee firm } \\
\text { is Ontario. }{ }^{313} \text { In other words, a deal is categorized in "other", when: (1) } \\
\text { there is a tie (e.g., two funds in Ontario, two in Quebec); or, (2) the } \\
\text { location of the funds that form the majority of funds in the incumbent } \\
\text { syndicate and the location of the investee differ from each other. }\end{array}$ \\
\hline & Model 4 & $\begin{array}{l}\text { A categorical variable defined as above, except that all the funds that } \\
\text { participated in the deal are taken into account (not only the incumbent } \\
\text { funds). }\end{array}$ \\
\hline \multirow[t]{11}{*}{ Experience } & Model 1 & $\begin{array}{l}\text { The analyses employ, as alternate specifications, each of the following } \\
\text { four measures of experience to ensure robustness of findings. }\end{array}$ \\
\hline & & $\begin{array}{l}\text { - Age: age of the management company of the fund at the time of the } \\
\text { cutoff point; }\end{array}$ \\
\hline & & $\begin{array}{l}\text { - Funds raised: the number of funds the management company of the } \\
\text { fund had raised by the time of the cutoff point; }\end{array}$ \\
\hline & & $\begin{array}{l}\text { - Companies invested: the number of entrepreneurial firms in which the } \\
\text { management company of the fund had invested by the time of the } \\
\text { cutoff point; }\end{array}$ \\
\hline & & $\begin{array}{l}\text { - Exit attained: the number of exits the management company of the } \\
\text { fund had attained by the time of the cutoff point. }\end{array}$ \\
\hline & Model 2, 4 & $\begin{array}{l}\text { The analyses employ, as alternate specifications, each of the following } \\
\text { four measures of experience to ensure robustness of findings. } \\
\text { For sole investments: }\end{array}$ \\
\hline & & $\begin{array}{l}\text { - Age: age of the management company of the fund at the time of the } \\
\text { deal; }\end{array}$ \\
\hline & & $\begin{array}{l}\text { - Fund raised: the number of funds the management company of the } \\
\text { fund had raised by the time of the deal; }\end{array}$ \\
\hline & & $\begin{array}{l}\text { - Company invested: the number of entrepreneurial firms in which the } \\
\text { management company of the fund had invested by the time of the } \\
\text { deal; }\end{array}$ \\
\hline & & $\begin{array}{l}\text { - Exit attained: the number of exits the management company of the } \\
\text { fund had attained by the time of the deal. }\end{array}$ \\
\hline & & $\begin{array}{l}\text { For syndicated investments, experience is measured by the age of the } \\
\text { oldest venture capital firm, the number of funds raised by the venture } \\
\text { capital firm that has raised most funds, the number of entrepreneurial }\end{array}$ \\
\hline
\end{tabular}

${ }^{313}$ In model 2 , location is defined as the province of the investee firm, whereas in model 3 , it is defined taking both the investee's and investors' locations into consideration. This is because the way to define location used in model 3 generates a category, "other," that includes cases of ties (e.g., deals with two funds in Ontario and two in Quebec), which are by definition correlated with the dependent variable (sole versus syndicated investments) if it were used for model 2.

${ }^{314}$ For each of the four measures of experience, a natural $\log$ and categorical transformations were also attempted (except for the number of exits variable, which produces a large number of missing values when transformed to the natural logarithm, i.e., there are a number of funds that have not attained a successful exit). 
firms invested by the venture capital firm that had invested most in entrepreneurial firms, or the number of successful exits experienced by the venture capital firm that has taken the most portfolio companies to a successful exit (all at/by the time of the deal), among the management companies in the syndicate (it is assumed that the most experienced venture capitalist is the most influential in the syndicate).

Model 3,5 Same as the above, except that only the incumbent fund(s) is/are taken into account.

Presence Model 2 A dummy variable equal to 1 if the investor is foreign or if the syndicate of foreign includes one (or more) foreign fund.

fund

* Model 1: logistic regression on the probability of a fund having a syndication ratio greater than $50 \%$ (Hypothesis 2).

* Model 2: logistic regression for first financing rounds of the probability that a deal is syndicated (Hypothesis 2 \& 3).

* Model 3: logistic regression for later financing rounds on the probability of a new investor being added (Hypothesis $2 \& 3$ ).

* Model 4: Poisson regression of the number of syndicate members (Hypothesis 4).

* Model 5: a pairwise binary logistic, and multinomial logistic, regressions for later financing rounds of the probability that a new investor is larger than the incumbent and of the probability that a new investor is smaller than the incumbent (Hypothesis 5a). Also, a pairwise binary logistic, and multinomial logistic, regressions for later financing rounds of the probability that a new investor is foreign and of the probability that a new investor is Canadian (Hypothesis $5 b$ ).

The rationales for the inclusion of, and expected direction of the impact of, each of the control variables are as follows.

Industry sector of the investee

There is evidence that certain sectors are more likely to involve syndication than others (Giot and Schwienbacher, 2004). In particular, Hopp and Rieder (2006) and Bygrave (1987, 1988) provide empirical observations consistent with the view that when the entrepreneurial firm is in a high-innovative sector (compared with when it is engaged in a low-innovative business) monitoring and value-adding activities require venture capitalists to have more specific knowledge and expertise, increasing the necessity of 
syndication. Accordingly, this study controls for potential sectoral effects, expecting higher syndication activity in investments in non-traditional sectors.

\section{Type of the fund/syndicate}

Previous studies report significant differences among different types of venture capital funds (Gompers and Lerner, 1999b; Schwienbacher, 2005; see II-1-2-3). For example, there is a view that non-private funds are less concerned about profit maximization (Cumming and MacIntosh, 2002; Siegel, Siegel, and Macmillan, 1988; Wang, Wang and $\mathrm{Lu}, 2002)$. Thus, private independent funds may arguably be more active in syndicating their investments and adding a new investor to their syndicates because syndication is a mechanism that provides venture capitalists with a source of additional capital; enables a greater diversification of risk; and allows for more efficient monitoring/value-adding activities. According to this logic, LSVCCs may be expected syndicate relatively less due to the combination of statutory constraints, the inefficient statutory governance structures, and less-skilled managers associated with LSVCCs - all of which imply less efficient mechanisms for profit maximization (see II-1-2-5). Likewise, when an incumbent syndicate comprises only foreign funds, it is might be expected to have a higher probability of addition of new investor, in order to further reduce the shortcomings associated with distant investments (costly monitoring and value-adding, severe information asymmetry, etc., Bruining, Verwaal, Lockett, Wright, and Manigart, 2006; Hopp and Rieder, 2006; Sorenson and Stuart, 2001; see II-2-2-2 and II-2-3-2).

\section{Location of the fund/deal}


Significant differences across different venture capital communities have been reported (Florida and Kenney, 1988; Gupta and Sapienza, 1992; Elango, Fried, Hisrich, and Polonchek, 1995). In particular, there seems to be a significant difference between funds and deals in Quebec and those in other provinces, possibly reflecting regional and cultural differences (Cumming and Johan, 2006). Alternatively, from the perspective of industry structure, funds and deals in Quebec may have greater syndication activity as there is a relatively large number of large funds in the Quebec region. Likewise, low syndication activities may be found in provinces where large funds are rare, such as the Prairies and Atlantic provinces (that is, small funds are unable to find syndication partners (recall that there are only two funds in Alberta, one in Saskatchewan, one in Manitoba, and none in the Atlantic that report capital under management in excess of $\$ 165$ million $\mathrm{CDN})$ ).

The "Other" location variable category for model 3 includes those cases where the investee's location and the province in which the majority of funds in its syndicate are sited differ. ${ }^{315}$ It is expected that when most incumbent investors are located outside of the investee's province, a new (local) investor is likely to enter in order to mitigate incumbents' problems associated with distant investments (costly monitoring and valueadding activities, Bruining, Verwaal, Lockett, Wright, and Manigart, 2006; Hopp and Rieder, 2006; Sorenson and Stuart, 2001; Lerner, 1995; Cumming, 2006; see II-2-2-2). Thus, this category of the location variable may have a positive and significant coefficient.

315 "Other" category also includes cases of tie (e.g., two funds in Ontario, two in Quebec). 


\section{Experience of the fund/syndicate}

Following Hochberg, Ljungqvist, and Lu (2007), we assume that experience acquired in the running of one fund carries over to the venture capital firm's next fund, as success in a first-time fund often enables the venture capital firm to raise one or more follow-on funds (Kaplan and Schoar, 2005). Thus, experience is measured at the parent firm, rather than the fund, level. Measures of experience include:

- Age of the management company of the fund (following Barry et al., 1990; Lerner, 1994a, 1994b; Gompers, 1996; Kaplan, Martel and Stromberg, 2004; Giot and Schwienbacher, 2004: Cumming, Schmidt, and Waltz, 2006; Cumming, Fleming, and Schwienbacher; 2006).

- Number of funds previously raised by the management company of the fund (following Cumming, Fleming, and Schwienbacher, 2006; Giot and Schwienbacher, 2004).

- Number of entrepreneurial firms the management company of the fund has financed (following Gompers, Kovner, Lerner, and Scharfstein, 2005, 2006; Hopp and Rieder, 2006; Sorenson, 2007).

- Number of successful exits the management company of the fund has experienced (following Barry et al., 1990).

This variable is added to control for smaller (likely less experienced) venture capital funds' desire for syndication with other (more experienced) venture capital funds. The smaller funds' motives might include being able to draw on the larger fund's expertise, 
networks, and information so as to enhance deal selection, monitoring/control, and valueadding activities (Bruining, Verwaal, Lockett, Wright and Manigart, 2006; among others; see II-2-2-2). ${ }^{316}$

For the sake of brevity, in section one the results of a specification with "age of the management company of the fund" as an experience measure were presented. Models were re-estimated using each of the alternative measures of experience; however, doing so did not change the conclusions of any of the analyses. Hence, findings were deemed to be robust to choice of the experience measure.

\footnotetext{
${ }^{316}$ It is unclear to which direction experience affects syndication. Experienced venture capitalists may have less need to acquire expertise from other venture capitalists (i.e., less need for syndication), but they are more likely to be invited to a syndicate due to their well-established central position within the venture capital community (Lerner, 1994a; Sorenson and Stuart, 2001; Hochberg, Ljungqvist, and Lu, 2007). Less experienced venture capitalists may have stronger desire to syndicate in order to acquire expertise, but may be less welcomed to a syndicate for their lower reputation (Hopp and Rieder, 2006; see II-2-4).
} 
Presence of foreign fund ${ }^{317}$

It is expected that foreign funds are less likely to make a sole investment in a Canadian entrepreneurial firm (even if they have greater capital availability and thus are able to provide sufficient funding to the entrepreneurial firm) because they tend to lack familiarity with the Canadian market and distant investments are difficult to find, monitor and add value (Bruining, Verwaal, Lockett, Wright, and Manigart, 2006; Hopp and Rieder, 2006; Sorenson and Stuart, 2001; see II-2-2-2). The variable, “presence of foreign fund" controls for this effect, being expected to have positive and significant coefficient.

${ }^{317}$ In model 2, the variable "presence of foreign investor" is a control variable, while in model 3 and thereafter, this variable is one of the explanatory variables to measure the size of the incumbent funds. The rationale is as follows.

In model 2, the size and characteristics of all the investors in the deal were taken into account. It is expected that foreign funds rarely make a sole investment in a Canadian entrepreneurial firm, due to costly monitoring and value-adding activities associated with distant investments. This variable is therefore expected to have a positive correlation with the probability of a deal to be syndicated (meaning: it is used for controlling the effect of distant investments). In fact, the analysis revealed that no foreign fund made a sole investment in a Canadian entrepreneurial firm for the first round financing.

In model 3 and thereafter, the size and characteristics of only the incumbent funds are taken into account. It is expected that the presence of one (or more) foreign fund in an incumbent syndicate means greater capital availability among incumbent investors, reducing the probability of the entrance of a new investor (meaning: the presence of foreign investor variable is one of the explanatory variables to measure the size of the incumbent syndicate). No first round investment made solely by foreign funds means no incumbent syndicate that consists only by foreign funds ( foreign funds have already had one (or more) local investor as a syndicate partner), thus it is unlikely that syndicates with a foreign fund(s) add a new investor for the purpose of mitigating the problems associated with distant investments).

Nevertheless, if the incumbent syndicate consists of a large number of foreign funds, they may decide to add a local investor for a further reduction of the problem of the distant investment. This effect was controlled by one category of "type" variable, "Foreign", which takes the value one when the majority of funds in the incumbent syndicate is formed by foreign funds. This category is expected to have a positive impact on a new investor entry (this and the "presence of foreign fund" variable are correlated, but not perfectly. For example, in the sample used for Model 3, there are 169 (out of 789) cases where at least one foreign fund is present (i.e., "presence of foreign fund" $=1$ ), whereas there are 62 cases where the majority of funds in the incumbent syndicate is formed by foreign funds (i.e., "Foreign" category of type variable = $1)$ ). 


\section{Appendix II: Control Variables for Analyses of Exit}

This Appendix II discusses the control variables employed in the regression analyses of exit patterns. Table A-2 presents the list of control variables along with reference to models in which they were used and their respective definitions.

Table A-2: List of Controlling Variables for Analyses on Exit

\begin{tabular}{|c|c|c|}
\hline $\begin{array}{l}\text { Variable } \\
\text { Name }\end{array}$ & $\begin{array}{l}\text { Included in } \\
\text { Model(s) }\end{array}$ & Definition \\
\hline \multirow[t]{2}{*}{ Industry } & Model 6 & $\begin{array}{l}\text { Industry sector of the investee. A dummy variable coded } 1.0 \text { if the } \\
\text { investee is in a high tech sector (Life Sciences, IT, Other } \\
\text { Technologies); } 0.0 \text { otherwise (i.e., Traditional). }\end{array}$ \\
\hline & Model 7 & $\begin{array}{l}\text { Industry sector of the investee. A categorical variable with four levels } \\
\text { (Life Sciences, IT, Other Technologies, Traditional). }\end{array}$ \\
\hline \multirow[t]{2}{*}{ Type } & Model 6 & $\begin{array}{l}\text { Type of fund (if sole investment), or the fund type that forms the } \\
\text { majority of the syndicate (if syndicated investment) as of the financing } \\
\text { round prior to either the exit or to the termination point of December } \\
31^{\text {st }} \text {, 2009. A dummy variable equal to } 0.0 \text { if the fund is private } \\
\text { independent, } 1.0 \text { if it is not. }{ }^{319}\end{array}$ \\
\hline & Model 7 & $\begin{array}{l}\text { Type of the fund (if sole investment), or the fund type that forms the } \\
\text { majority of the syndicate (if syndicated investment) as of the financing } \\
\text { round prior either to the exit or to the termination point of December } \\
31^{\text {st }}, 2009 \text {. A categorical variable with six levels (private independent, } \\
\text { corporate affiliated (institutional investor, corporate financial, } \\
\text { corporate industrial), government affiliated (LSVCC, provincial VCC), } \\
\text { government, foreign, and other. }\end{array}$ \\
\hline Location & Model 6 & $\begin{array}{l}\text { A categorical variable with four levels: (1) Ontario; (2) British } \\
\text { Columbia; (3) Quebec; (4) Prairies, Atlantic, and other, as of the } \\
\text { financing round either to the exit or to the termination point of } \\
\text { December } 31^{\text {st }}, 2009 \text { (it is converted into four dummies when entered } \\
\text { into the model). A deal is classified in a particular category, say, } \\
\text { Ontario, when the following two conditions are met: (1) the location of } \\
\text { the funds that form majority of funds in the syndicate is Ontario; and, } \\
\text { (2) the location of the investee firm is Ontario. In other words, a deal is } \\
\text { categorized in "other", when: (1) there is a tie (e.g., two funds in }\end{array}$ \\
\hline
\end{tabular}

318 "Life Sciences" includes biopharmaceuticals, healthcare, medical devices and equipment, and medical/biotech software and information services. "IT" includes communications and networking, electronics and computer hardware, internet focus, semiconductors, software, and other IT services. "Other Technologies" includes energy and environmental technologies and other technologies. "Traditional" includes consumer and business services, consumer products, finance, manufacturing, retailers, and miscellaneous.

319 Non private independent includes institutional investor, corporate financial, corporate industrial, LSVCCs, Provincial VCC, government, and other (see II-1-2-3 for the definition of fund types). "Other" includes cases of tie (e.g., the deal made by two private independent and two LSVCCs). 


\begin{tabular}{|c|c|c|}
\hline & & $\begin{array}{l}\text { Ontario, two in Quebec); or, (2) the location of the funds that form the } \\
\text { majority of funds in the syndicate and the location of the investee } \\
\text { differ from each other. }\end{array}$ \\
\hline & Model 7 & $\begin{array}{l}\text { A categorical variable defined as above, but with five levels ("Prairies } \\
\text { and Atlantic Provinces" separated from "other"), i.e., (1) Ontario; (2) } \\
\text { British Columbia; (3) Quebec; (4) Prairies and Atlantic Provinces; and, } \\
\text { (5) other. }\end{array}$ \\
\hline \multirow[t]{6}{*}{ Experience } & Model 7 & $\begin{array}{l}\text { The analyses employ, as alternate specifications, each of the following } \\
\text { four measures of experience to ensure robustness of findings. }{ }^{321} \\
\text { For sole investments: }\end{array}$ \\
\hline & & $\begin{array}{l}\text { - Age: age of the management company of the fund as of the } \\
\text { financing round prior to the exit or the termination point of } \\
\text { December } 31^{\text {st }}, 2009 \text {; }\end{array}$ \\
\hline & & $\begin{array}{l}\text { Funds raised: the number of funds the management company of the } \\
\text { fund had raised; }\end{array}$ \\
\hline & & $\begin{array}{l}\text { - Companies invested: the number of entrepreneurial firms in which } \\
\text { the management company of the fund had invested; } \\
\text { - Exit attained: the number of exits the management company of the } \\
\text { fund had attained; }\end{array}$ \\
\hline & & $\begin{array}{l}\text { All are measured as of the financing round prior to the exit or as of the } \\
\text { termination point of December } 31^{\text {st }}, 2009 \text {. }\end{array}$ \\
\hline & & $\begin{array}{l}\text { For syndicated investments, experience is measured by the age of the } \\
\text { oldest venture capital firm, the number of funds raised by the venture } \\
\text { capital firm that has raised most funds, the number of entrepreneurial } \\
\text { firms invested in by the venture capital firm that had invested in most } \\
\text { entrepreneurial firms, or the number of successful exits experienced by } \\
\text { the venture capital firm that has taken the most portfolio companies to } \\
\text { a successful exit, among the management companies in the syndicate } \\
\text { (It is assumed that the most experienced venture capitalist is the most } \\
\text { influential in the syndicate). }\end{array}$ \\
\hline Exit & Model 6 & A dummy variable coded 1.0 if the investee was acquired by a non- \\
\hline Type of Exit & Model 6 & A dummy variable coded 1.0 for IPO exits; 0.0 for M\&As. \\
\hline $\begin{array}{l}\text { Round } \\
\text { number }\end{array}$ & Model 6 & $\begin{array}{l}\text { One of the three measures of the level of the investee company's } \\
\text { development. The round number of the last financing round prior to } \\
\text { the exit (or the termination point of December } 31^{\text {st }}, 2009 \text { ). A } \\
\text { categorical variable with three levels, the first, the second, the third or } \\
\text { more (it is converted into three dummies when entered into the model). }\end{array}$ \\
\hline & Model 7 & $\begin{array}{l}\text { A categorical variable defined as above, except that it has four levels, } \\
\text { the first, the second, the third, and the fourth or more. }\end{array}$ \\
\hline $1^{\text {st }}$ Time since & Model 6 & $\begin{array}{l}\text { One of the three measures of the level of the investee company's } \\
\text { development. The number of days since the } 1^{\text {st }} \text { venture capital }\end{array}$ \\
\hline
\end{tabular}

${ }^{320}$ Due to the small number of observation for the "Prairies and Atlantic" category, it is merged with "other".

${ }^{321}$ For each of the four measures of experience, natural log and categorical transformations were also attempted (except for the number of exit variable, which produces a large number of missing values when transformed to the natural logarithm, i.e., there are a number of funds that have not attained a successful exit). 


\begin{tabular}{lll}
\hline investment & $\begin{array}{l}\text { investment to the last financing round prior to the exit or the } \\
\text { termination point of December } 31^{\mathrm{st}}, 2009 \text { (in 100-day units). }\end{array}$. $^{322}$ \\
$\begin{array}{l}\text { In(\$Amount } \\
\text { Disbursed) }\end{array}$ & Model 6,7 & $\begin{array}{l}\text { One of the three measures of the level of the investee company's } \\
\text { development. The natural logarithm of the dollar amount of venture } \\
\text { capital disbursed to the investee at the financing round prior to the exit } \\
\text { or as of the termination point of December } 31^{\text {st }}, 2009 \text { (in million } \\
\text { CDN). }\end{array}$
\end{tabular}

* Model 6: OLS regression on the total amount of venture capital received by the investee by the time of its exit (Hypothesis 6).

* Model 7: proportional hazard model of time to exit (IPO, M\&A) (Hypothesis 7).

The rationale of the inclusion, and expected direction of the impact, of each of the control variables are as follows. ${ }^{323}$

Industry sector of the investee

Existing studies find significant industry effects on the probability (or time to) a successful exit (e.g., Cumming and MacIntosh, 2001b; Das, Jagannathan, and Sarin, 2003; Laine and Torstila, 2003; Giot and Schwienbacher, 2006; Makri, Junkunc, and Eckhardt, 2007). ${ }^{324}$ The need for oversight and the amount of capital necessary for growth are likely different among entrepreneurial firms in different industries, which may affect venture capitalists' decision to go public (Lerner, 1994b) and the probability of (time to) a successful exit. The speed of product development could be substantially

${ }^{322}$ To mitigate the bias resulting from venture capital investors timing the exit (Lerner (1994b), see II-3-26) or the time taken for legal procedures associated with an IPO or an M\&A, this variable measures the length of time from the investee's $1^{\text {st }}$ venture capital investment to the last financing round.

323 As the fund approaches the termination date, pressure to exit the fund's investments increases (Cumming and MacIntosh, 2002; Laine and Torstila, 2003) potentially leading venture capitalists to exit an investment via an inferior form and/or with an inferior valuation. To control for this factor, the original plan included fund age in regression analyses. However, this issue applies only to closed funds (i.e., private independent limited partnerships), and more than 50 percent of deals in the data $(1,196$ out of 2,315) are without private independent. Even in a syndicate where one (or more) private independent fund is present, it is uncertain the extent to which the private independent's time to termination issue affects the syndicate's overall decision. For this reason, the fund age variable was not included in the actual analyses.

${ }^{324}$ However, there seems no consistency across studies as to which industries have significant impacts as well as their directions. 
different across industry, and thus also affects time to exit. ${ }^{325}$ If large funds are more likely to invest in a particular industry and companies engaged in that industry are more likely to attain a successful exit (such as IT sector during the Internet Bubble), then the relationship between fund size and hazard of a successful exit reflects the impact of venture capitalists' strategy, rather than their financial capacity, on investment outcomes. The work therefore controls for potential industry effects.

\section{Type of the fund/syndicate}

Previous studies report significant differences in exit probabilities among different types of venture capital funds (Gompers and Lerner, 1999b, Chapter 5; Hochberg, Ljungqvist, and Lu, 2007; Cumming, Fleming, Schwienbacher, 2006). As discussed, some argue that non-private independent funds are less concerned about profit maximization (Cumming and MacIntosh, 2002; Siegel, Siegel, and Macmillan, 1988; Wang, Wang and Lu, 2002): this is likely to affect venture capitalists' exit decisions (and hazard of a certain type of exit). In particular, a significant difference in the hazard of exit may be observed between entrepreneurial firms backed by LSVCCs and those backed by other types of funds (private independent, in particular) due to the combination of statutory constraints, inefficient statutory governance structures, and less-skilled managers (all associated with LSVCCs), all of which imply less efficient mechanisms for profit maximization (see II-12-5). Likewise, Canadian firms backed by a syndicate formed mainly by foreign funds may have a higher hazard to a successful exit, as larger capital infusions from foreign

\footnotetext{
${ }^{325}$ There is a general view that medical products take longer to develop (Lerner, 1994b; Cumming and MacIntosh, 2001b; Giot and Schwienbacher, 2006).
} 
funds' deeper pockets foster the investee's growth. On the other hand, it could be argued that they may have a lower probability of (longer time to) a successful exit, as geographic barriers may hinder foreign investors from close monitoring and effective value-adding activities. Thus, as in the case of syndication testing, models control for the type of venture capital funds/syndicates.

\section{Location of the deal}

The frequency and type of successful exit varies across regions (Laine and Torstila, 2003; Giot and Schwienbacher, 2006). In particular, a significant difference may be detected between deals in Quebec and those in other provinces, perhaps reflecting legal and cultural differences (Cumming and Johan, 2006). Quebec deals may exhibit a higher hazard to a successful exit, as Quebec has a relatively large number of large funds. Likewise, a low hazard to a successful exit may be associated with deals located in provinces where large funds are absent (for example, Prairie and Atlantic Provinces).

The "Other" category of location variable includes the cases where the investee's location and the province in which most funds are sited differ. ${ }^{326}$ As discussed, distant investments are associated with severe information asymmetry, costly monitoring and value-adding activities (Bruining, Verwaal, Lockett, Wright, and Manigart, 2006; Hopp and Rieder, 2006; Sorenson and Stuart, 2001; Lerner, 1995; Cumming, 2006; see II-2-22). Thus, this category of the location variable may exhibit a lower hazard for a successful exit.

326 "Other" category also includes cases of tie (e.g., two funds in Ontario, two in Quebec). 
Experience of the fund/syndicate

One of the main purposes of adding control variables is to isolate the effect of the venture capitalist's financial capacity from that of its non-financial capability. As discussed, previous studies consider that the size of a fund contains information on the venture capitalist's experience and skills. To the extent that this view holds, it is possible that the positive relationship between the chance of a successful exit and the size of the venture capital fund reflect experienced venture capitalists' higher skill in identifying promising entrepreneurial firms and better value-adding services, rather than larger funds' capacity to provide larger amounts of financing. It is therefore important to control for venture capitalists' experience. ${ }^{327}$ This is measured for the analysis of exits exactly as described for analysis of syndication.

For the sake of brevity, in section two the results of a specification with "age of the management company of the fund" as an experience measure were presented. Changing the experience measure to any of the other three alternatives does not alter the conclusion of any of the analyses.

\section{Exit location}

This variable is used to control for differences in listing requirements of stock exchanges, size and liquidity of capital and M\&A markets, expectations and risk appetite of investors, legal and tax environments, etc., across different countries (mainly between the

${ }^{327}$ However, as expected, experience measures were correlated with size, which necessitated careful interpretation of the results (see Appendix IV, as well as VI-3-1-2). 
United States and Canada (Cumming and MacIntosh, 2001a, 2002; and II-3-2-6). The size and nature of entrepreneurial firms that attain an international exit could arguably differ from those that attain a domestic exit. Durufle $(2006,2007)$ reports that the value of a firm at the time of its exit is higher when the exit takes place outside of Canada (see II-3-4), implying that entrepreneurial firms that attained a foreign exit may have to be larger in size and need to have received a greater amount of venture capital by that time. Accordingly, it is particularly important to control for exit location in the analysis of the impact of fund sizes on exit values (i.e., Hypothesis 9 and 10).

Type of exit

It has been argued that an entrepreneurial firm must achieve a particular level of development in order to reach the point for either an IPO or an acquisition exit (Cochrane, 2005; Giot and Schwienbacher, 2006), and that the required level of development is higher for an IPO than for an acquisition exit (Gompers, 1995; Makri, Junkunc, and Eckhardt, 2007; Schwienbacher, 2005). Given that a larger amount of capital infusion is usually necessary for an entrepreneurial firm to attain a higher level of development, a greater amount of venture capital is expected to be associated to an IPO exit in testing Hypothesis $6 .^{328}$

Amount disbursed, round number, and time since first investment

\footnotetext{
${ }^{328}$ Gompers (1995), Giot and Schwienbacher (2006) and Makri, Junkunc, and Eckhardt (2007) have found that the total quantity of venture capital received is significantly positively associated with the likelihood of an IPO exit but not with the likelihood of an M\&A exit.
} 
Small funds are more likely to invest in companies at the early stage of development. If those small funds tend to exit their investees when they are still at an early stage, for the purpose of, for example, grandstanding, this may, in turn, manifest as an association between small funds and smaller amounts of venture capital infusions by the time of the exit (in model 6). ${ }^{329}$ To control this, two variable were added in model 6 , the round number of, and the length of time since the first investment to, the financing round prior to the exit. ${ }^{330}$

Moreover, if small funds are more likely to invest in companies at the early stage of development, it implies that they are more likely to invest in companies that are farther away from a successful exit. This may, in turn, manifest as an association between small funds and a longer time to a successful exit (in model 7). To control this, again, two variables were added in model 7 , the amount disbursed at, and the round number of, the financing round prior to either to the exit or to the termination point of December $31^{\text {st }}$, 2009. ${ }^{331}$ For the detailed description of those variables, see V-1-2-2.

\footnotetext{
${ }^{329}$ Gompers (1996) argues that young venture capital firms take companies public earlier in order to signal their ability to potential investors and build reputation (see II-3-2-4). If so, the association between small funds (arguably managed by young venture capital firms) and smaller amounts of venture capital infusions by the time of their investees' exits (possibly detected in model 6) could be a reflection of small funds' tendency to effect premature exits, rather than their limited financial availability.

${ }^{330}$ However, it is also probable that small funds exit their investments prematurely due to their limited financial availability.

${ }^{331}$ The length of time since the first investment used for the estimation of the hazard ratio in model 7 (the proportional hazard model).
} 


\section{Appendix III: ANOVA, OLS, and Poisson Regression Analyses on Capital Availability}

For ANOVA, funds were classified in quartiles based on their size (funds under management), and the average value of each of the four capital availability measures (see V-1-1-1 for the definitions) for each size quartile was calculated. The ANOVA and the post-hoc t-tests examined for the equality of average capital availability across different size categories. The mean values, p-values for the ANOVA and post-hoc t-tests for the entire sample are presented in Table A-3, panel 1; those for the sample of private independent funds only are in panel 2.

In the OLS regression estimates, each of the three constraint measures (Cap-CC[\$Dis], Cap-CC[\$Ave], and Ave\$Dis; see V-1-1-1 for the definitions) were used, alternatively, as dependent variables. Independent variables comprised dummy variables corresponding to fund size categories, and control variables reflecting type of fund and fund location. In the Poisson regression model the dependent variable was the number of portfolio companies and independent variables included fund size measures and control variables.

The basic inference from these analyses confirms that from analysis of the correlation coefficients in V-1-1-1: for the entire sample, all four capital availability measures were positively and significantly correlated with size; for the sample of private independent funds, three out of four measures of capital availability (Cap-CC[\$Dis], Cap-CC[\$Ave], 
and Ave\$Dis) were positively and significantly correlated with size; however, the number of portfolio companies (\#PC) was not significantly correlated with size. 
Table A-3: ANOVA and Post-hoc t-tests of Capital Availability

\begin{tabular}{|c|c|c|c|c|c|}
\hline \multicolumn{6}{|c|}{ Panel 1: Entire Sample } \\
\hline \multicolumn{2}{|l|}{$\begin{array}{l}\text { Size Category } \\
(\$ 000)\end{array}$} & \#PC & Cap-CC[\$Dis] & Cap-CC[\$Ave] & Ave\$Dis \\
\hline \multirow{3}{*}{$\begin{array}{l}\text { Very Small } \\
(<\mathbf{3 0 , 0 0 0 )}\end{array}$} & Mean & 4.38 & 3163.61 & 2810.60 & 1780.90 \\
\hline & $\mathbf{N}$ & 26 & 25 & 25 & 26 \\
\hline & S.D. & 3.71 & 3905.76 & 4002.82 & 1453.08 \\
\hline Small $(30,000 \leq$, & Mean & 6.37 & 10479.68 & 10192.33 & 2226.71 \\
\hline \multirow{2}{*}{$<75,000)$} & $\mathbf{N}$ & 30 & 29 & 29 & 30 \\
\hline & S.D. & 5.67 & 11752.42 & 12316.26 & 1183.35 \\
\hline Middle & Mean & 6.84 & 17907.16 & 18349.82 & 2646.51 \\
\hline$(75,000 \leq$ & $\mathbf{N}$ & 19 & 18 & 18 & 19 \\
\hline$<165,000)$ & S.D. & 4.44 & 17274.55 & 17500.56 & 1065.91 \\
\hline Large & Mean & 17.19 & 80793.36 & 80991.91 & 2907.62 \\
\hline \multirow[t]{2}{*}{$(165,000 \leq)$} & $\mathbf{N}$ & 16 & 15 & 15 & 16 \\
\hline & S.D. & 27.73 & 116240.54 & 115292.63 & 1548.69 \\
\hline \multirow[t]{3}{*}{ Total } & Mean & 7.80 & 22037.13 & 21965.72 & 2306.71 \\
\hline & $\mathbf{N}$ & 91 & 87 & 87 & 91 \\
\hline & S.D. & 12.89 & 55336.48 & 55155.32 & 1354.72 \\
\hline \multirow{7}{*}{$\begin{array}{l}\text { ANOVA } \\
\text { p-values of post- } \\
\text { hoc t-tests* }\end{array}$} & & .011 & .000 & .000 & .036 \\
\hline & Very Small v/s Small & 134 & .004 & .006 & .211 \\
\hline & Very Small v/s Middle & .050 & .000 & .000 & 033 \\
\hline & Very Small v/s Large & .024 & .002 & .002 & .022 \\
\hline & Small v/s Middle & .758 & .086 & .067 & .215 \\
\hline & Small v/s Large & .044 & .002 & .002 & .103 \\
\hline & Middle v/s Large & .118 & .030 & .030 & .560 \\
\hline \multicolumn{6}{|c|}{ Panel 2: Private Independent Only } \\
\hline \multicolumn{2}{|c|}{ Size Category $(\mathbf{\$ 0 0 0})$} & \#PC & Cap-CC[\$Dis] & Cap-CC[\$Ave $]$ & Ave\$Dis \\
\hline Very Small & Mean & 4.59 & 3279.00 & 2601.07 & 1277.38 \\
\hline \multirow[t]{2}{*}{$(<30,000)$} & $\mathbf{N}$ & 17 & 16 & 16 & 17 \\
\hline & S.D. & 4.27 & 4060.48 & 4217.62 & 913.70 \\
\hline \multirow{3}{*}{$\begin{array}{l}\text { Small }(30,000 \leq \\
<75,000)\end{array}$} & Mean & 5.83 & 11560.74 & 11541.85 & 2457.22 \\
\hline & $\mathbf{N}$ & 23 & 22 & 22 & 23 \\
\hline & S.D. & 5.07 & 12714.21 & 13330.29 & 1229.82 \\
\hline \multirow{6}{*}{$\begin{array}{l}\text { Middle } \\
(\mathbf{7 5 , 0 0 0 \leq}, \\
<165,000) \\
\text { Large } \\
(\mathbf{1 6 5 , 0 0 0 \leq )}\end{array}$} & Mean & 6.27 & 20053.32 & 20260.08 & 2573.24 \\
\hline & $\mathbf{N}$ & 15 & 14 & 14 & 15 \\
\hline & S.D. & 4.18 & 18801.63 & 19294.87 & 1150.48 \\
\hline & Mean & 9.30 & 86143.66 & 86322.08 & 2810.06 \\
\hline & $\mathbf{N}$ & 10 & 9 & 9 & 10 \\
\hline & S.D. & 8.41 & 127132.39 & 125941.91 & 1296.62 \\
\hline \multirow[t]{3}{*}{ Total } & Mean & 6.14 & 22341.63 & 22230.78 & 2229.70 \\
\hline & $\mathbf{N}$ & 65 & 61 & 61 & 65 \\
\hline & S.D. & 5.42 & 55169.35 & 54989.63 & 1262.68 \\
\hline \multirow{7}{*}{$\begin{array}{l}\text { ANOVA } \\
\text { p-values of post- } \\
\text { hoc } t \text {-tests* }\end{array}$} & & .182 & .001 & .001 & .002 \\
\hline & Very Small v/s Small & .420 & .017 & .014 & .002 \\
\hline & Very Small v/s Middle & .272 & .002 & .001 & .001 \\
\hline & Very Small v/s Large & .064 & .014 & .013 & .001 \\
\hline & Small v/s Middle & .781 & .114 & .118 & .772 \\
\hline & Small v/s Large & .151 & .009 & .009 & .462 \\
\hline & Middle v/s Large & .242 & .066 & .064 & .636 \\
\hline
\end{tabular}

\footnotetext{
* Equal variances assumed. Results were similar to those obtained when equal variances were not assumed.
} 
Table A-4: OLS Regressions on capital Availability Measures

\begin{tabular}{|c|c|c|c|c|c|c|c|c|c|c|c|c|c|}
\hline & & \multicolumn{4}{|c|}{ Specification A: $\ln (\mathrm{Cap}-\mathrm{CC}[\$ \mathrm{Dis}])$} & \multicolumn{4}{|c|}{ Specification B: $\ln ($ Cap-CC[\$Ave]) } & \multicolumn{4}{|c|}{ Specification C: $\ln$ (Ave\$Dis) } \\
\hline & & $\mathbf{B}$ & S.E. & t-value & Sig. & $\mathbf{B}$ & S.E. & t-value & Sig. & B & S.E. & t-value & Sig. \\
\hline \multicolumn{2}{|c|}{ Constant } & 9.198 & 0.334 & 27.557 & 0.000 & 9.338 & 0.378 & 24.731 & 0.000 & 8.022 & 0.152 & 52.838 & 0.000 \\
\hline \multicolumn{2}{|c|}{ Type: Other } & -0.218 & 0.327 & -0.667 & 0.507 & -0.191 & 0.385 & -0.495 & 0.622 & -0.060 & 0.139 & -0.430 & 0.668 \\
\hline \multirow[t]{3}{*}{ Size } & $\begin{array}{l}\text { Very Small } \\
(x<30)\end{array}$ & -1.263 & 0.454 & -2.781 & 0.007 & -1.284 & 0.541 & -2.371 & 0.021 & -0.710 & 0.192 & -3.697 & 0.000 \\
\hline & $\begin{array}{l}\text { Small } \\
(30<=x<75)\end{array}$ & -0.703 & 0.389 & -1.807 & 0.075 & -0.775 & 0.444 & -1.743 & 0.086 & -0.316 & 0.177 & -1.787 & 0.078 \\
\hline & $\begin{array}{l}\text { Large } \\
(165<=x<500)\end{array}$ & 0.930 & 0.446 & 2.084 & 0.041 & 0.700 & 0.503 & 1.391 & 0.169 & 0.005 & 0.204 & 0.024 & 0.981 \\
\hline \multirow{3}{*}{$\begin{array}{l}\text { Locati } \\
\text { on }\end{array}$} & $\mathbf{B C}$ & -0.022 & 0.402 & -0.055 & 0.956 & 0.014 & 0.482 & 0.029 & 0.977 & 0.075 & 0.163 & 0.461 & 0.646 \\
\hline & QC & 0.722 & 0.380 & 1.900 & 0.062 & 0.430 & 0.431 & 0.999 & 0.322 & -0.314 & 0.169 & -1.854 & 0.068 \\
\hline & $\begin{array}{l}\text { Prairies and } \\
\text { Atlantic }\end{array}$ & 0.673 & 0.473 & 1.424 & 0.159 & 0.633 & 0.557 & 1.136 & 0.260 & -0.322 & 0.214 & -1.505 & 0.136 \\
\hline \multicolumn{2}{|l|}{$\mathbf{R}$} & 0.585 & & & & 0.496 & & & & 0.487 & & & \\
\hline \multicolumn{2}{|c|}{ R Square } & 0.342 & & & & 0.246 & & & & 0.237 & & & \\
\hline \multicolumn{2}{|c|}{ Adjusted R Square } & 0.275 & & & & 0.164 & & & & 0.170 & & & \\
\hline \multicolumn{2}{|l|}{$\mathbf{N}$} & 77 & & & & 72 & & & & 87 & & & \\
\hline
\end{tabular}

* Dependent variable for specification A is $\ln (\mathrm{Cap} / \# \mathrm{PC}), \mathrm{B} \ln ($ Ave $\$ D i s), \mathrm{C} \ln (\mathrm{Cap}-\mathrm{CC}[\$ \mathrm{Dis}]), \mathrm{D} \ln (\mathrm{Cap}-\mathrm{CC}[\$ A v e])$. See V-1-1-1 for definitions.

* Type is the type of the fund. A dummy variable coded 1.0 if not private independent, 0.0 if private independent.

* Size is the amount of capital under management of the fund at the time when the fund was three years old (four dummies, base category $=$ Middle $(75<=x<165$ in $\$$ million CDN)).

* Location is a categorical variable for the fund's location (four dummies, base category = Ontario). 
Table A-5: Poisson Regression on Number of Portfolio Companies

\begin{tabular}{|c|c|c|c|c|c|}
\hline & & $\mathbf{B}$ & S.E. & Wald & Sig. \\
\hline Intercept & & 1.744 & 0.097 & 320.351 & 0.000 \\
\hline Type: Other & & 0.680 & 0.078 & 75.404 & 0.000 \\
\hline \multirow[t]{3}{*}{ Location } & $\mathbf{B C}$ & -0.089 & 0.101 & 0.772 & 0.380 \\
\hline & QC & 0.285 & 0.095 & 8.994 & 0.003 \\
\hline & Prairies & -0.875 & 0.165 & 28.038 & 0.000 \\
\hline \multirow[t]{4}{*}{ Size (\$000) } & Very Small $(x<30,000)$ & -0.486 & 0.137 & 12.571 & 0.000 \\
\hline & $\begin{array}{l}\text { Small } \\
(30,000<=x, 75,000)\end{array}$ & -0.090 & 0.116 & 0.602 & 0.438 \\
\hline & $\begin{array}{l}\text { Large } \\
(165,000<=x<500,000)\end{array}$ & 0.928 & 0.109 & 71.943 & 0.000 \\
\hline & Value & df & Value/df & & \\
\hline Deviance & $\mathbf{5 5 5 . 9 5 0}$ & 82 & 6.780 & & \\
\hline Scaled Deviance & 555.950 & 82 & & & \\
\hline $\begin{array}{l}\text { Pearson Chi- } \\
\text { Square }\end{array}$ & 621.853 & 82 & 7.584 & & \\
\hline $\begin{array}{l}\text { Scaled Pearson } \\
\text { Chi-Square }\end{array}$ & 621.853 & 82 & & & \\
\hline $\begin{array}{l}\text { Likelihood Ratio } \\
\text { Chi-Square } \\
\mathbf{N}\end{array}$ & $\begin{array}{r}325.585 \\
90\end{array}$ & & & & \\
\hline
\end{tabular}

* Dependent variable is the number of companies in the fund's portfolio.

* Type is the type of the fund. A dummy variable coded 1.0 if not private independent, 0.0 if private independent.

* Size is the amount of capital under management of the fund at the time when the fund was three years old (a categorical variable with four levels, base category = Middle $(75<=x<165$ in $\$$ million CDN)).

* Location is a categorical variable for the fund's location (a categorical variable with four levels, base category $=$ Ontario). 


\section{Appendix IV: Correlation Coefficient Estimates between Size and}

\section{Experience}

This dissertation uses four variables to measure the degree of experience of a venture capital firm: the age of the firm (the number of years since founded), the number of funds the firm has raised, the number of companies in which the firm has invested, and the number of successful exits the firm has attained (see Appendix I and II for detail). These experience measures are, in alternative specifications, included in the analyses as control variables, so as to better extract the pure capital availability effect that the fund size variable holds, distinguishing the experience-related information that the size variable might contain. ${ }^{332}$

Table A-6: Correlation between Size and Experience Measures (As of December $31^{\text {st }}, 2009$ )

\begin{tabular}{|c|c|c|c|c|c|}
\hline & Size & Age & \# of Fund Raised & \# of Companies Invested & \# of Exits \\
\hline Size & 1 & $.304 * * *$ & 0.104 & $.377 * * *$ & $.167^{* *}$ \\
\hline Age & & 1 & $.324 * * *$ & $.362 * * *$ & $.352 * * *$ \\
\hline \# of Fund Raised & & & 1 & $.583 * * *$ & $.811 * * *$ \\
\hline $\begin{array}{l}\text { \# of Companies } \\
\text { Invested } \\
\text { \# of Exits }\end{array}$ & & & & 1 & $.791 * * *$ \\
\hline
\end{tabular}

However, except for the number of funds raised, all three experience measures are significantly (at one percent level) correlated with size. This result implies a caveat that

\footnotetext{
${ }^{332}$ Table A-6 shows the correlations measured as of December 31, 2009. As a robustness check, the correlation coefficients were estimated at two other alternative points in the development of the venture capital funds: when funds were three years old and when they were five years old. Correlations were not as strong as those reported in Table A-6 (size remained significantly correlated with age but not with the other three experience variables).
} 
inclusion of those variables may introduce multicollinearity in the multivariate analyses, possibly obscuring interpretation. 


\section{Appendix V: Contingency Tables between Size of Syndicate, Number of Investors, and Presence of Foreign Investors}

This section presents contingency tables among the three variables to measure the size of a syndicate used in the analyses: size of the syndicate (the size of the largest Canadian fund in the syndicate), the number of funds involved in the syndicate, and the presence or absence of a foreign fund in the syndicate. Those tables show that the three size measures are correlated such that foreign and large funds are more likely to be found in a syndicate with a large number of investors and that the presence of a foreign investor is more likely to be found in a syndicate with a large fund.

Table A-7: Contingency Table between Number of syndicate Members and Preence of Foreign Fund

\begin{tabular}{llrrrr}
\hline & & \multicolumn{4}{c}{ Presence of Foreign Fund } \\
\hline \# of Syndicate Members & No Foreign & Foreign Present & Total & \\
$\mathbf{1}$ & Observed & 544 & 29 & 573 \\
& Expected & 444 & 129 & \\
$\mathbf{2 , 3 , 4}$ & Observed & 1005 & 138 & 1143 \\
& Expected & 886 & 257 & 599 \\
$\mathbf{5}$ or more & Observed & 245 & 354 & \\
& Expected & 464 & 135 & 2315 \\
Total & & 1794 & 521 & \\
& & & Asymp. Sig. (2-sided) \\
Pearson Chi-Square & 631.203 & df & 2 & 0.000 & \\
\hline
\end{tabular}


Table A-8: Contingency Table between Number of syndicate Members and Size of the Syndicate

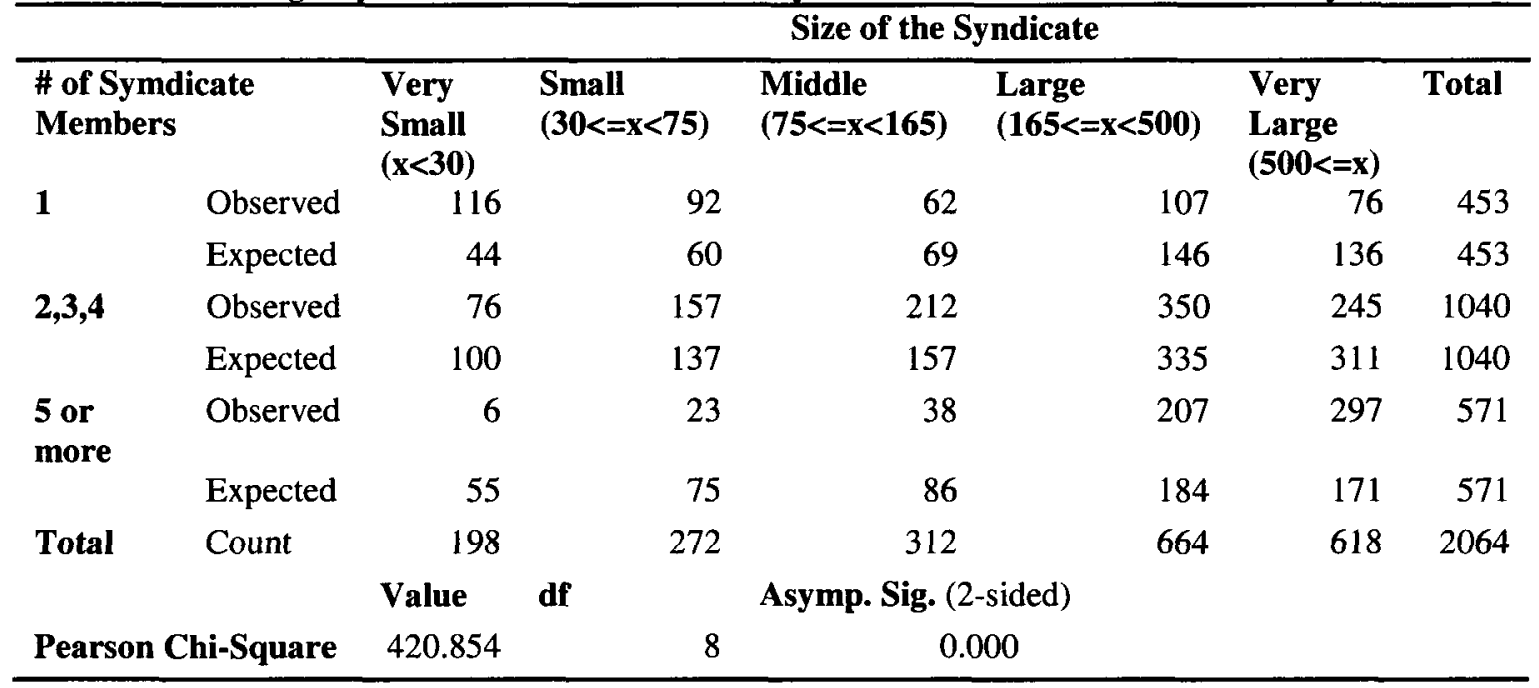

Table A-9: Contingency Table between Size of the Syndicate and Presence of Foreign Fund

\begin{tabular}{|c|c|c|c|c|c|c|c|}
\hline & & & & $\overline{\mathbf{S i}}$ & & & \\
\hline \multirow{3}{*}{$\begin{array}{l}\text { Presence of } \\
\text { Foreign } \\
\text { Fund } \\
\text { No Foreign }\end{array}$} & & $\begin{array}{l}\text { Very } \\
\text { Small } \\
(\mathbf{x}<30)\end{array}$ & $\begin{array}{l}\text { Small } \\
(30<=x<75)\end{array}$ & $\begin{array}{l}\text { Middle } \\
(75<=x<165)\end{array}$ & $\begin{array}{l}\text { Large } \\
(165<=x<500)\end{array}$ & $\begin{array}{l}\text { Very } \\
\text { Large } \\
(500<=x)\end{array}$ & Total \\
\hline & Observed & 188 & 249 & 268 & 502 & 441 & 1648 \\
\hline & Expected & 158 & 217 & 249 & 530 & 493 & 1648 \\
\hline \multirow{2}{*}{$\begin{array}{l}\text { Foreign } \\
\text { Present }\end{array}$} & Observed & 10 & 23 & 44 & 162 & 177 & 416 \\
\hline & Expected & 40 & 55 & 63 & 134 & 125 & 416 \\
\hline Total & Count & 198 & 272 & 312 & 664 & 618 & 2064 \\
\hline \multirow{2}{*}{$\begin{array}{l}\text { Pearson } \\
\text { Chi-Square }\end{array}$} & Value & df & \multicolumn{5}{|c|}{ Asymp. Sig. (2-sided) } \\
\hline & 93.386 & 4 & & 0.000 & & & \\
\hline
\end{tabular}




\section{Appendix VI: OLS Estimation of Total Amount Invested with}

\section{"Percentage-of-Large-Funds" Variable}

Table A-10 presents the results of the OLS estimations on the total amount of venture capital received by the investee by the time of the exit. This relates to the results of testing Hypothesis 11 (see V-2-1), in which an additional explanatory variable, the percentage of large funds, was added to the analysis employed to test Hypothesis 6. As discussed in V-2-4, when the estimation was run with the entire sample (specification A), the percentage-of-large-fund variable was negative and significant ( $p$-value $=0.000$ ) essentially detecting the "Quebec" effect. When the Quebec observations were excluded from the sample (specification B), the percentage-of-large-fund variable was insignificant (p-value $=0.377)$.

Table A-10: OLS Regression on Total Amount Invested by the Time of Exit

\begin{tabular}{lccccccccc}
\hline & \multicolumn{3}{c}{$\begin{array}{l}\text { Specification A:Sample with } \\
\text { Quebec Observations }\end{array}$} & \multicolumn{5}{c}{$\begin{array}{l}\text { Specification B:Sample without } \\
\text { Quebec Observations }\end{array}$} \\
\hline & B & S.E. & t-value & Sig. & \multicolumn{1}{l}{ B } & S.E. & t-value & Sig. \\
Constant & 0.556 & 0.332 & 1.676 & 0.104 & 0.534 & 0.804 & 0.664 & 0.515 \\
\# of Syndicate & 0.391 & 0.075 & 5.201 & 0.000 & 0.530 & 0.101 & 5.258 & 0.000 \\
Members & & & & & & & & \\
Presence of & 0.594 & 0.354 & 1.677 & 0.104 & 0.548 & 0.384 & 1.427 & 0.170 \\
Foreign Fund & & & & & & & & \\
Size & 0.631 & 0.303 & 2.080 & 0.046 & -0.115 & 0.327 & -0.352 & 0.729 \\
\% Large Funds & -5.765 & 1.459 & -3.952 & 0.000 & -4.691 & 5.190 & -0.904 & 0.377 \\
Round\#_2nd & 0.710 & 0.267 & 2.663 & 0.012 & & & & \\
R & 0.794 & & & & 0.782 & & & \\
R Square & 0.760 & & & & 0.736 & & & \\
Adjusted R Square & 0.660 & & & & 0.661 & & & \\
\hline
\end{tabular}

* Dependent variable is the natural logarithm of the total amount of venture capital invested in the entrepreneurial firm.

* Explanatory variables are: (1) size (a dummy variable equals 1.0 if the amount of capital under management of the fund (if only one investor) or the largest fund in the syndicate (if more than one investor) is greater than or equal to $\$ 165$ million CDN; 0.0 otherwise); (2) the number of syndicate 
members; and, (3) the presence of foreign fund (a dummy variable equals 1.0 if there is a (or more) foreign fund in the syndicate; 0.0 otherwise). Those variables are forced to enter the equation.

* Control variables include: (1) industry (a dummy variable coded 1.0 if the investee is in the high-tech sector (Life Sciences, IT, Other Technologies), 0.0 if Traditional); (2) the number of days since the investee received its first venture capital investment (in 100 days); (3) round number of the financing round prior to the exit (first, second, third or more; two dummies with base case of first); (4) the type of the fund (if one investor) or the type of the funds that form the majority of funds in the syndicate (if more than one investor. A dummy variable coded 1.0 if not private independent, 0.0 if private independent; (5) location of the deal (four dummies: Ontario, British Columbia, Quebec, Prairies and Atlantic Provinces, other, with base case of Ontario, see Appendix II for the definition); (6) the level of experience of the fund (if one investor) or the level of experience of the most experienced fund in the syndicate (if more than one investor), measured by the age of the management company of the fund; (7) exit location (a dummy variable equals 1.0 if the investee was acquired by a non-Canadian corporation or listed on a foreign exchange; 0.0 otherwise); (8) type of exit (a dummy variable equals 1.0 if the investee was exited via an IPO; 0.0 via M\&A). Control variables enter the equation through the stepwise procedure.

* The analyses employ, as alternate specifications, each of the following four measures of experience to ensure robustness of findings: age of the management company of the fund, the number of funds the management company of the fund had raised, the number of entrepreneurial firms the management company of the fund had invested, and the number of exits the management company of the funds had experienced, at/by the time of the deal was made. For syndicated deals, experience is measured by the level of experience of the most experienced fund in the syndicate. For each of the four measures of experience, a natural $\log$ and categorical transformations are also attempted (except for the number of exit variable, which produces a large number of missing values when transformed to the natural logarithm, i.e., there are a number of funds that have not attained a successful exit). For the sake of brevity, however, the specification using age of fund (as a natural number value) as an experience variable is reported. Results of specifications with other experience measures (and with/without the natural $\log$ /categorical transformations) do not differ from the above, and are available upon request. 